\title{
A TEORIA KANTIANA DO DEVER: A ARQUEOLOGIA DE UMA PAISAGEM MORAL
}

\author{
Guilherme Alfradique Klausner ${ }^{1}$
}

\section{Resumo}

O presente trabalho tem como objetivo sintetizar conhecimentos extraídos de autores das mais diversas tradições da história da filosofia acerca das condições de formação da paisagem moral kantiana a partir de um método arqueológico, focado na construção histórico-filosófica da noção kantiana de dever. Para a consecução desse objetivo, foram adotadas como obras base as de Villey e Agamben sobre o tema, bem como foram delimitados campos autônomos em relação ao contexto dos estudos realizados acerca do pensamento kantiano a serem abordados a partir da premissa inicial (quais sejam: técnica enquanto paradigma da modernidade e o impacto do nominalismo, do protestantismo e do neoestoicismo em Kant). Nas reflexões de caráter mais propriamente filosófico, o trabalho de Agamben assumiu franca relevância, bem como foram incorporadas observações de caráter sociológico fundadas no trabalho de Max Weber sobre a ética intramundana protestante. A conclusão, seguindo as dos estudos base, aponta para a consolidação, na obra kantiana, de um processo de alteração do Weltanschauung da intelligentsia filosófica no Ocidente, com severa repercussão na vida dos habitantes desse hemisfério. A partir dessa conclusão, crê-se, é necessário repensar a noção de dever tanto em suas implicações jurídicas quanto em suas implicações psicológicas.

Palavras-chave: Teoria do Dever kantiana; Officium; Causa Instrumentalis; Gestell; Teoria do Estado e da Justiça pós-positivista.

A teoria moral kantiana tem sido profundamente influente na modernidade, tendo mesmo adquirido um caráter de concretização última do projeto moral iluminista. Muitos autores se filiam a ela e, especialmente no Direito, o crescimento de sua importância enquanto axiologia frente às alternativas hegeliana e marxista, a partir das décadas de setenta e oitenta, é considerado um dos marcos do movimento pós-positivista.

No presente trabalho, que compõe, junto com outras duas partes, uma obra maior que vem sido desenvolvido a partir de indagações, próprias de uma perspectiva jurídica, acerca da formação do Estado Moderno, é posta a seguinte questão: como se desenvolveu a teoria kantiana do dever? No entanto, fosse tão simples a questão, bastava a leitura da obra kantiana, seus estudos preparatórios e o estudo do professor Giorgio Agamben acerca do mesmo tema, Opus Dei: Arqueologia do Oficio. O que motivou a elaboração desse trabalho, para além da perseguição das origens da teoria do dever kantiana enquanto ideia dotada de uma pseudo-história e

\footnotetext{
${ }^{1}$ Mestrando em Direito na Universidade do Estado do Rio de Janeiro - UERJ. Professor substituto na Universidade do Estado do Rio de Janeiro - UERJ. E-mail: guilhermeklausner@gmail.com
} 
de, em paralelo, resquícios arqueológicos ${ }^{2}$ que levavam à construção de uma verdadeira história do conceito kantiano, foi a busca pelas circunstâncias do condicionamento intelectual do próprio Kant. Buscou-se saber porque ele veio a acreditar que as suas soluções não eram só as mais corretas a partir de uma perspectiva científica, mas as melhores dentro de um contexto de escolha moral do meio de elaboração da relação entre sociedade e Estado.

A doutrina kantiana, quando estudada no âmbito da academia de direito, vem, em regra, incorporada dentro de uma tentativa de renovação da abordagem científica da relação entre o cidadão e o Estado, encampada por doutrinadores como Robert Alexy, John Rawls, Ronald Dworkin, Klaus Wilhelm Canaris e, no Brasil, Humberto Ávila, Daniel Sarmento, Luís Roberto Barroso, Ingo Starlet e Ricardo Lobo Torres, que vagam em cima da dita virada kantiana (LOBO TORRES, 2009, p. 156).

Por que? Porque, após o desastre humanitário que foi a Segunda Guerra Mundial, o Direito passou por um processo de recuperação dessa sua faceta axiológica, ou seja, do estudo dos Valores que o inspiram. Tanto é assim que os Princípios foram recuperados no debate jurídico e mesmo no espectro normativo como guias dos discursos jurídicos. Esta recuperação imprimiu um caráter axiológico muito forte no Direito do pós-Guerra.

Em todas as discussões sobre valores, a argumentação sempre remete em algum ponto, a uma autoridade, responsável por dar envergadura a eleição deste ou daquele valor. As discussões são absolutamente livres, até a intervenção da autoridade que afirma suas conclusões ou mesmo um discurso específico não original como o correto. As discussões nesses ambientes, pode-se dizer, buscam uma determinada verdade em relação a um sistema, ou mesmo a Verdade absoluta, e a autoridade tende a ser o intérprete autorizado da Verdade Revelada (a Igreja, por exemplo - ou seja, quem tem o poder de decidir) ou o filósofo (que, apesar de não ser o responsável pelo ato decisório, é considerado relevante enquanto árbitro intelectual de ideias, por vezes sendo tão influente quanto a própria autoridade na formulação do discurso que servirá de veículo para o ato decisório). ${ }^{3}$ No momento histórico atual, que ainda é, em certa medida, uma vaga do pósGuerra, o discurso jurídico é eminentemente kantiano, por muitas razões, que não são o objeto desse trabalho. ${ }^{4}$

\footnotetext{
${ }^{2}$ É importante pensar aqui que a situação perante a qual o pesquisador se encontrava era a de um terreno na qual os escritos kantianos apontavam para trabalhos insertos em outras tradições e diziam que lá estavam seus antepassados diretos e doutrinas jurídicas que faziam o mesmo com os próprios escritos kantianos, adotando inclusive seu relato histórico sobre as outras tradições, como se todos estivessem vinculados entre si.

${ }^{3}$ Vale ressaltar que esse papel nem sempre é ocupado por um filósofo ou pensador. Basta que a pessoa tenha capacidade de influenciar na formulação do discurso veículo do ato decisório.

${ }^{4}$ Remete-se, no entanto, ao artigo do Professor Diogo de Figueiredo Moreira Neto: " [...] ...mas seria numa terceira fase, desenvolvida na segunda metade do século vinte, que se reincorporariam plenamente os valores abandonados pela velha dogmática positivista, tudo sob a ponderável influência das mutações experimentadas pela sociedade e pelo Estado, notadamente após um meio século de mega-conflitos dominado por radicalismos políticos, por ideologias escravizantes e por autocracias tirânicas, construídas sobre o esqueleto formal e sem valores do Estado de Direito, em que a legalidade se confundia com a legitimidade e se ignorava a dimensão ética da licitude. Essa nova fase, da jurisprudência de valores, foi a resposta ao grande vazio axiológico e teleológico criado pela legalidade formalista, suportando um Direito sem alma, sedimentada depois de breves
} 
É de importância fundamental então analisar as circunstâncias do nascimento do kantismo, bem como suas características e, mais especificamente, se ele de fato apresenta qualquer renovação verdadeira dos pressupostos basilares da análise da relação entre o Estado e o Cidadão.

Faz-se isso aqui porque, ao assumir-se que a moral kantiana é a que pauta a relação entre Estado e cidadão por causa de uma supremacia a ela intrínseca, como, por exemplo, sua veracidade enquanto estatuto biopolítico, desconstrói-se o argumento de diversas linhas de pesquisa que buscam contestar a atuação do homem ocidental, especialmente após o período revolucionário na Europa e nos Estados Unidos (1640-1789) no mundo, que por vezes foi chamada de "civilizatória". Se de fato o kantismo define hoje as relações entre Estado e indivíduo, a partir dessa premissa da existência de uma superioridade intrínseca a esse sistema, é desnecessário estudar as circunstâncias psiquícas que levaram os povos a erigir institutos civilizacionais diversos, e como, no Ocidente, esses institutos foram os engendradores da instituição que hoje é conhecida como Estado, ${ }^{6}$ porque então já se teria a linha de chegada do desenvolvimento civilizacional se não já atingida, ao menos já definida.

Considerando que alguns assumam que é assim, o que se propõe aqui é: será que o homem moderno desejaria morar no projeto político imaginário de Kant? Quais seriam as consequências disso? Um pensamento só pode ser entendido no seu cerne a partir das interlocuções que ele travou com seus contemporâneos e com seus antecessores.

Não é, portanto, olhando para o que Kant escreveu que se deve fazer esta prospecção, porque ela, se assim se procedesse, seria muito incerta. É absolutamente impossível saber como seria morar na sociedade

\footnotetext{
vacilações doutrinárias em que fervilhou, num primeiro momento, a indignação de movimentos contestadores mais radicais e de menor fôlego, como, por exemplo, o da chamada teoria crítica, desenvolvida logo depois de terminada a II Guerra Mundial pela denominada Escola de Frankfurt, contando com os nomes de L. Althusser e, depois, J. Habermas, mas que acabou por negar o próprio Direito, ao predicar uma jurisprudência política. Distintamente, a jurisprudência de valores, partindo da nova concepção de justiça de John Rawls e contando com famosos próceres, como G. Bettiol, L. Legal y Lacambra, R. Dworkin e Karl Larenz, logo frutifica na doutrina e nos tribunais da República Federal da Alemanha, que à época reconstruía seu Direito Constitucional sob o enfoque da democracia substancial, notadamente em trabalhos que logo se tornaram clássicos, como, entre outros, os de K. Engisch, P. Häberle, F. Muller, R. Alexy (na teoria dos princípios) e W. Canaris, este último definindo claramente o Direito como um sistema aberto de valores, ou seja, expresso por meio de princípios dotados de força normativa, com conteúdo de valor (axiologische) ou de fim (teleologische). Nada surpreendente, portanto, que, depois do auge e da queda das grandes potências bélicas e dos mega-Estados, e do pavor constante de um iminente holocausto nuclear, tenha ocorrido "essa reaproximação entre ética e direito, a partir do que se convencionou chamar de "virada kantiana" (kantische Wende), e ela viesse a se tornar um fundamento do Estado Democrático da Direito, reentronizando as dimensões éticas perdidas da legitimidade e da licitude e restabelecendo o primado da sociedade sobre o Estado e do homem sobre a sociedade, expressado nos direitos fundamentais, um conceito que passou a pairar acima dos ordenamentos jurídicos e dos Estados, para inspirá-los e informá-los." in NETO, Diogo de Figueiredo Moreira. Aspectos Jurídicos do Brasil Contemporâneo. O Pós-Positivismo Chega ao Brasil. Inaugura-se um Constitucionalismo de Transição. Revista Eletrônica sobre a Reforma do Estado, Salvador, nº. 6, junho/julho/agosto, 2006. Disponível na Internet: <http://www.direitodoestado.com.br>. Acesso em: 24 de maio de 2017.

${ }^{5}$ Nunca ousaram chamar as cruzadas de civilizatórias. Inclusive, usou-se o termo biopolítico especificamente com o intuito de distinguir claramente a aliança entre um saber/poder antropocêntrico enquanto instrumento de dominação do Ocidente pósrevolucionário (apesar de suas origens, traçadas por Michel Foucault em seu "O Nascimento da Biopolítica", antedatarem o período revolucionário) de quaisquer outras pretensões de dominação porventura formuladas por povos insertos no que se veio a considerar como o Ocidente, em oposição ao Oriente, ou a África.
} 
cosmopolita perfeita, porque diversas nuances suas dependem de detalhes, seja de vínculo entre áreas do pensamento kantiano que não restaram bem esclarecidas na obra de Kant, seja por questões de semiótica dos termos no pensamento kantiano.

O que se pode fazer, apesar do limitado material existente para este tipo de estudo, é tentar compreender detalhes da paisagem moral da filosofia kantiana, sem fazer, vez que este não é o objetivo do trabalho, um estudo dela propriamente.

Que se quer dizer com isso? Quando um filósofo cria um grande sistema, ou seja, um sistema que busca promover a compreensão de toda ou ao menos de parte significativa de toda a realidade, ele o faz através de instrumentos intelectuais, ideias-chaves, que revelam o que está escondido por trás do sensualmente apreensível ou que meramente constatam o que é sensualmente apreensível. Estas ideias-chaves, não querendo aqui se negar a genialidade de qualquer autor, têm uma origem, que deve ser estudada para se compreender exatamente o sentido de uma filosofia. A ideia também é uma parte da realidade e é possível também compreender o que está por trás dela, socialmente (circunstâncias sociais que favoreceram a sua formação) ou filosoficamente (as ideias na qual ela se baseia). As ideias que compõem um grande sistema, se postas em uma estrutura mental, formam o que se pode chamar de uma paisagem. Se as ideias são harmônicas entre si, a paisagem é bela; se não, é grotesca; se as ideias têm relação com o real, são vivas; se não, são mortas.

Uma das ideias centrais, e mais importante para este trabalho, da filosofia kantiana é a ideia de dever, porque ela vai determinar a formação da realidade contemporânea, ${ }^{7}$ e ela nasce junto com a modernidade. Então buscar-se-á seu desenvolvimento propriamente filosófico, através de uma arqueologia, e seu desenvolvimento sócio-histórico. A outra grande ideia kantiana que, no entanto, ainda não conta com estudos mais desenvolvidos é de dignidade da pessoa humana. Ela, no entanto, tem uma história mais longa e mais complexa, e o seu desenvolvimento pleno (Kant só a insere em um contexto normativo ético) é mais antigo do que o da ideia de

\footnotetext{
${ }^{6}$ E aqui se quer dizer o Estado Moderno.

${ }^{7}$ Max Weber, analisando a questão da importância do protestantismo para o desenvolvimento do espírito do capitalismo contemporâneo afirmou que a "ideia do 'dever profissional' ronda nossa vida como um fantasma das crenças religiosas de outrora." Esta tradução, no entanto, de José Marcos Mariano de Macedo (publicada pela Companhia das Letras) se diferencia da tradução clássica de Talcott Parsons, publicada pela Routledge, ao vincular o conceito de Beruf unicamente com o de vocação profissional. É incito ao protestantismo que a vocação seja muito mais compreendida como uma disposição a servir com base em um comando que adquire proporções metafísicas do que como uma mera submissão ao dever profissional que, de toda forma, envolve diversas espécies de regras. Assim, considerando que esta obra será usada mais a frente, se usará ora a tradução da Companhia das Letras, ora a da Routledge, e, eventualmente, uma terceira, que combine ambas, no intuito de esclarecer e instrumentalizar os conceitos, sempre dando os devidos créditos. Assim, desde já, a tradução que parece mais adequada, de Talcott Parsons, versa que "a ideia de obedecer ao Chamado (se usará ora vocação, ora Chamado, como parecer melhor - ambas contém referência clara à voz de comando - N. do T.) cerca nossas vidas como o fantasma de crenças religiosas mortas." in WEBER, Max. The Protestant Ethic and The Spirit of Capitalism. Nova Iorque: Routledge, 2005, p. 124. A frase de Weber ecoará as críticas anteriores de Schopenhauer e Nietzsche à doutrina kantiana do dever, que afirmavam a sua mal escondida verve religiosa. Esta indistinção do trabalho e a vida, presente na própria tradução para o português do sentido da palavra Beruf, característica maior da funcionalização da vida, será vista mais a frente, na análise de Jünger sobre o tipo do Trabalhador.
} 
dever e, consequentemente, não pode ser considerado um traço marcante da formação da ideia moderna de relação entre Estado e cidadão (vez que é justo isso que se busca aqui, que seja, o traço marcante da relação moderna entre Estado e cidadão).

\section{A TITULO DE INTRODUÇÃO}

Antes de se entrar no tema delineado acima, no entanto, cabe explicar: o que é o pós-positivismo referido acima? Segundo seus próprios autores, pós-positivismo é o novo paradigma jurídico que visa substituir a fundamentação do Estado Social nos paradigmas positivistas e utilitaristas. Afasta-se o pensamento jurídico do positivismo historicista ou sociológico, à moda de Marx, Comte ou Max Weber, e do normativista, segundo o modelo de Kelsen, Merkl ou Hart. O pós-positivismo abandona todos os pressupostos da jurisprudência dos conceitos (Begriffjurisprudenz) e os da jurisprudência dos interesses (Interessenjurisprudenz), na busca de uma jurisprudência dos valores

(Wertungsjurisprudenz) ou dos princípios (Prinzipienjurisprudenz). Substitui uma matriz hegeliana por uma matriz kantiana. Promove a reaproximação entre o direito e a moral (LOBO TORRES, 2009, p. 156).

O termo "virada kantiana" (kantische Wende), muito utilizado entre os póspositivistas, é expressão empregada por O. Höffe (HÖFFE, 1990, p. 351) e determinada temporalmente como ocorrida durante a década de 70. Os autores mais famosos que se filiam a esta virada são John Rawls, Ronald Dworkin, Jürgen Habermas e Robert Alexy. É comum a associação entre estes dois fenômenos, quais sejam, o pós-positivismo e a virada kantiana.

Emmanuel Kant (1724-1804), referência máxima para a maior parte dos póspositivistas, mais do que tudo, tentou promover, com sua filosofia, uma mudança na estruturação lógica habitual dos sistemas éticos, criando uma nova ordem de deveres e direitos. Ele nasceu na cidade de Königsberg, no leste da Prússia, e lá morreu, com quase oitenta anos. Sua família era de classe-média, seus pais sendo pietistas, uma seita protestante que enfatizava a religiosidade interior e as boas obras. Ele foi excelente aluno na faculdade de Königsberg, na qual ingressou com dezesseis anos. Durante algum tempo, trabalhou como tutor, até que, aos trinta e um anos, foi contratado para seu primeiro trabalho acadêmico, ainda que não assalariado, como palestrante, sendo remunerado com base no número de alunos que compareciam.

Como palestrante, ele era popular e produtivo, dando por volta de vinte palestras por semana, de temas que incluíam metafísica, lógica, ética, direito, geografia e antropologia. Em 1781, aos cinquenta e sete anos, ele publicou sua primeira grande obra, A Crítica da Razão Pura, que desafiava a teoria empiricista do conhecimento associada a David Hume e a John Locke. Quatro anos depois, ele publicou Fundamentação da Metafisica da Moral, o primeiro de muitos trabalhos sobre filosofia moral. Cinco anos depois dos Princípios da Moral e da Legislação (1780) de Bentham, a Fundamentação de Kant fazia uma relevante crítica do utilitarismo. 
O livro argumentava que a moralidade não se trata de "maximizar" a felicidade ou qualquer outro bem. Trata-se de respeitar as pessoas como um fim em si mesmas. A Fundamentação apareceu logo depois da Revolução Americana (1776) e logo antes da Revolução Francesa (1789). Alinhado com o espirito e o embasamento moral destas duas Revoluções, o livro oferece uma poderosa sustentação daquilo que os revolucionários de ambos os movimentos chamavam de Direitos do Homem, e aquilo que se chama hoje de direitos universais do homem.

A Fundamentação se propõe a responder duas questões: qual é o princípio supremo da moral? O que é liberdade?

A ética kantiana é uma ética deontológica. Na Fundamentação e em outras posteriores, ele cria o conceito de Imperativo Categórico, que é definido em três fórmulas, sintetizadas na frase "Age de tal modo que a máxima da tua ação se possa tornar princípio de uma legislação universal." É uma ética do dever, que crê que o homem não deve se entregar aos seus desejos, mas ponderar racionalmente frente a cada escolha, de forma que a decisão por ele tomada esteja de acordo com o ideal por ele almejado (mas não em uma perspectiva relacional meio-fim).

A Justiça em Kant tratar-se-ia de harmonizar todas essas regras universais em uma ordem social. Estas regras universais, por serem ideais abstratos, não poderiam derivar de fatos empíricos, por isso Kant, ainda que contratualista, não se propõem a estabelecer nenhuma análise acerca deste contrato social que possa efetivamente promover a dedução de um valor. Assim, as comunidades não poderiam decidir leis justas, mas o indivíduo poderia fazê-lo através desta abstração, porque na comunidade seria envolvida a ponderação dos desejos e as expectativas de seus componentes, enquanto com a utilização da razão simples e pura não.

Esta norma universal, apesar de Kant não tentar deduzi-la, pode-se considerar emanada de cada ato público. Portanto se a norma for consentida por cada um e obedecida, isso por si só já a tornaria justa (SANDEL, 2009, p. 58). Kant é, antes de mais nada, um racionalista.

A questão é que Kant, ao promover esta abstração como único meio de se chegar a uma conclusão, dá espaço justamente ao positivismo jurídico (COMPARATO, 2016, p. 291). O positivismo jurídico é em primeiro lugar uma abstração da realidade, ou seja, desliga-se totalmente de fatos históricos ou contingentes no objetivo de encontrar uma estrutura puramente jurídica. Inclusive quando Kelsen se vê frente aos problemas suscitados pela sua teoria pura do Direito, ${ }^{8}$ argui a favor dela utilizando de um instrumental kantiano. Então, em primeiro lugar, é importante ressaltar o quão importante Kant foi para o positivismo.

O ponto principal é que Kant trabalha com uma ética do dever. Para além do indivíduo ter que se submeter a este dever indeterminado, que nada mais é do que uma lei moral planejada através da abstração total

\footnotetext{
${ }^{8}$ Aqui deve-se relembrar da polêmica do Guardião da Constituição, com Carl Schmitt.
} 
da realidade (COMPARATO, 2016, p. 293), ele tem que fazê-lo sem nenhum interesse próprio, até mesmo contra a sua vontade. Se sua vontade, seus desejos, forem de acordo com a norma, tanto melhor, mas esta parte de sua ação que foi conforme a norma por interesse, desejo, não importa, não é parte da ação moral, que é obedecer a norma por ela ser uma norma. Kant não trabalha com normas justas ou injustas na matriz aristotélica, consagrada em seu tempo na maior parte da doutrina jusfilosófica europeia, desde os escritos dos escolásticos até os jusracionalistas, apesar de combatida de forma progressivamente mais intensa a partir do século XIII.

Esta forma de pensar sustenta toda uma estruturação positiva no qual se sustenta a obediência à norma por esta ser uma norma. Isso pode parecer ser o oposto do que os próprios pós-positivistas pregam, mas não se pode esquecer que o pós-positivismo, se por certo representa, tratando-o enquanto ideologia jurídica, uma superação do positivismo, por sua vez não representa um abandono completo das premissas do próprio positivismo.

O direito positivo deve ser respeitado por ser direito positivo, afirmam os que se filiam ao póspositivismo, mas, enquanto categoria mental ética, deve ser promovida uma superação da norma meramente positiva para que seja incorporado a esta toda uma gama de valores éticos que desde a ascensão de um modelo mais positivista de ciência jurídica ficaram alijados de considerações mais profundas acerca de sua relevância.

Como isto afeta a percepção do Direito? Para além da simplificação das análises da obediência jurídica ( "obedeço porque é um comando" - em uma acepção naturalista de conceitos como Lei, Dever e Norma), que não permite real ponderação sobre o justo, bem como a imposição de uma lógica de submissão, afinal quem se insurge contra a lei

se insurge contra uma espécie de "imperativo categórico", a ética kantiana, se fosse tentado montar uma estrutura normativa a partir dela, levaria a uma teoria da Justiça da igualdade absoluta, que buscaria reprimir a injustiça intrinsecamente contida nas situações contingentes, involuntárias, como ressaltado acima.

Assim a maior parte da doutrina que, por exemplo, transborda para os aspectos filosóficos da fundamentação do Estado e está vinculada ao pós-positivismo tenta explicar o Estado, ou melhor, justifica-lo, não pela perspectiva dos processos materiais e intelectuais de sua formação, mas pelas suas possíveis razões de ser jusracionalistas. Confunde-se o ser ontológico com o serdeontológico.

A crítica que se faz não é à reflexão sobre os fins do Estado, mas à trasladação desta opinião mais ou menos fundamentada ao Direito como única verdade científica com vínculo com o real, ou seja, única análise que dá sentido a este real, ocupando o lugar de uma explicação mais fundada no esmiuçar dos processos que levaram à formação do Estado que há hoje, o Estado Moderno.

LEITOURGIA, KATHÉKON, OFFICIUM, CAUSA INSTRUMENTALIS: NASCE A 


\section{ONTOLOGIA DA EFETUALIDADE}

Mas por que, de toda a teoria kantiana, se deve estudar o Dever para se entender a relação entre cidadão e Estado? Como dito, o Dever é o centro da ética kantiana e a base da teoria política kantiana, bem

como dos princípios que a inspiram, faz depender a ordem política da moral de seus indivíduos. Kant, um filósofo, divide esta parte de seu grande sistema em Direito (que trata de sua teoria política jusracionalista), Política (uma elaboração imaginativa de suas conclusões acerca do Direito, contida na obra A Paz Perpétua) e Ética, que precede os trabalhos anteriores logicamente. Aos autores que se utilizam de aspectos da filosofia kantiana como base filosófica no Direito não interessou fazer esta divisão expressa, não permitindo assim um enfrentamento metodologicamente pautado de cada uma dessas teses kantianas, que em si, não tem qualquer aspecto vinculativo, a não ser se se assumam suas premissas como verdadeiras. Há que se perguntar então, em primeiro lugar, se a virada kantiana não contemplaria algum caráter político por si só. A esta pergunta não há resposta satisfatória, mas certos elementos que deveriam aparecer em uma hipotética resposta serão aqui trazidos.

O arquétipo de Dever, como elaborado por Kant, que claramente se reflete na obra do Professor Casalta Nabais, a que se refere por ser o doutrinador que mais buscou explicar a ideia filosófica do Dever para fundamentar sua tese acerca do Dever Fundamental de se pagar impostos, serve para exações supostamente juscientíficas que visam a vincular o comportamento do homem ao do Estado, trabalhados organicamente.

Deveres Fundamentais são, na obra do autor lusitano, "deveres jurídicos do homem e do cidadão que, por determinarem a posição fundamental do indivíduo, têm especial significado para a comunidade e podem por esta ser exigidos" (NABAIS, 1998, p. 64). Os Deveres Fundamentais desfrutaram durante muito tempo da total falta de atenção por parte dos especialistas em Direito Constitucional, restando à doutrina alemã da década de setenta recuperar o estudo deste conceito, quando em face da utilização dele pelos tribunais tedescos. ${ }^{9}$ Mas por que os Deveres Fundamentais caíram no esquecimento? Eles existiram como conceito jurídico antes?

Segundo Casalta Nabais, o Dever Fundamental se desenvolveu como espécie jurídica por caminhos muito tortuosos. A primeira menção ao conceito de Dever, anota ele, vem do tratado De Officiis, do político latino Cícero. Filosoficamente, importante anotar a influência do estoicismo, doutrina que pregava um rígido ascetismo, uma implacável perseguição da virtude e a submissão do homem a um transcendental conceito de Dever, no

\footnotetext{
${ }^{9}$ Casos de 22 de maio de 1975 e 29 de outubro de 1981 da Bundesverfassungsgerichts (Tribunal Constitucional Alemão), ambos relacionados a entrada de socialistas no funcionalismo público. Ambos são comentados por Casalta Nabais na referida obra, alardeando o autor a polêmica gerada quando do julgamento de ambos os casos, porquanto a decisão do Tribunal foi denegatória da assunção dos indivíduos em questão aos cargos públicos.
} 
cerne da formação do homem romano republicano. ${ }^{10}$

De fato, Giorgio Agamben, filósofo italiano, que trata em sua obra Opus Dei: Arqueologia do Ofício, acerca da introdução do Dever enquanto conceito dentro da ética finalista aristotélica e a criação de uma nova forma de pensar a ética, corrobora esta afirmação, ao afirmar que a primeira vez que se inclui o termo officium dentro de um contexto que torne possível sua compreensão para a contemporaneidade é como tradução do termo grego kathékon para o latim, na obra De Officiis de Cícero. O ofício, na perspectiva ciceroniana, não é algo que se deva incluir "nem entre os bens, nem entre os males" (CÍCERO, 2008, p. 29 apudAGAMBEN, 2013a, p. 75), mas sim algo que é "decoroso e conveniente fazer segundo as circunstâncias, sobretudo levando-se em conta a condição social do agente" (CÍCERO, 2008, p. 75 apud AGAMBEN, 2013a, p. 75). ${ }^{11}$ O termo kathékon, por sua vez, segundo Diógenes Laércio, teria sido primeiro introduzido por Zenão no vocabulário filosófico, definindo-o deste modo: "uma ação que possui uma razão plausível [eulogon [...] apologismon], como o ser consequente na vida, que se aplica também às plantas e aos animais; os os kathēkonta concernem de fato também a tais seres". Os estoicos especificavam o conceito de kathékon segundo o parâmetro de finalidade da ação. Assim, se certamente era sempre conveniente viver segundo a virtude (os estoicos chamariam estes atos de conformação da vida com a virtude de teleion kathékon), nem sempre é conveniente comer, passear ou assistir aulas. Logo, kathékon deve ser compreendido antes de tudo como um termo com duas variáveis sempre, uma circunstancial e uma subjetiva: não são todos que devem se portar da mesma forma nas mesmas situações - cada situação exige de cada pessoa um comportamento específico, o comportamento adequado.

A obra de Cícero tem dois gradientes: as fontes gregas das quais ele se apropria e a situação política na qual se insere, ou seja, a crise definitiva da res publica aristocrática romana. Os latinos, e isso é próprio deles, vinculavam o termo officium ao verbo efficere, no sentido de ação eficaz realizada ou que convém realizar em harmonia com a própria condição social (AGAMBEN, 2013a, p. 78).

A questão da condição social como determinante da ação eficaz, de uma ação que não era um "ofício de artesão" (AGAMBEN, 2013a, p. 77), mas decorrente do próprio papel do sujeito em sociedade, e a amplitude de ações que poderiam ser objeto de exigência de conteúdo moral (que, em Roma, por não existir a dicotomia que é própria da modernidade, será sempre relacionado a costumes) nestes termos, são indícios da intenção de Cícero de evitar a fragmentação do modus vivendi da res publica romana.

Neste sentido, Cícero diz: "pois nenhuma esfera da vida, nem a atinente a questões públicas, a questões privadas, a questões forenses ou a questões domésticas, nem quando ages por conta própria, nem quando te

\footnotetext{
${ }^{10}$ NABAIS, José Casalta. O dever fundamental de pagar impostos. Coimbra: Livraria Almedina, 1998, p. 41 e ss. Estes elementos do estoicismo serão relativizados através de sua reinserção no processo histórico que assim os definiu como fetiches como se verá mais à frente.

${ }^{11}$ Neste sentido, AGAMBEN, Giorgio. Opus Dei: Arqueologia do Ofício. São Paulo: Boitempo Editorial, 2013, p. 75.
} vol.11, nº. 02, Rio de Janeiro, 2018.pp. 1172- 1267 
associas a outra pessoa, pode estar isenta do dever" (AGAMBEN, 2013a, p. 78). Agamben conclui que, se, "a partir do século XVII a tradução de officium por 'dever' se torne corrente, falta no termo latino o forte sentido de obrigação (moral ou jurídica) que o dever havia de conquistar na vida moderna." ${ }^{12}$

Cícero afirma que toda questão "em torno do officium... apresenta dois aspectos:

o primeiro concerne ao sumo bem (finis bonorum), o segundo aos preceitos 'com os quais se pode dar forma ao uso da vida em todos os seus aspectos [in omnes partes usus vitae conformari possit]"' (AGAMBEN, 2013a, p. 81). Dar forma a vida, instituir a vida, é, para ele "Conduzir a vida" ( vitam degere), 'governar as coisas' (rem gerere)".13

Por curiosidade, cumpre registrar dado trazido por Agamben acerca da obra de

Max Pohlenz, Antikes Führertum. Lançada em 1934, a obra afirma que "o sentido último da obra ciceroniana era fornecer uma teoria do Führertum, da liderança política, como

'serviço prestado ao povo em sua integridade [Dienst am Volksganzen]". Para Pohlenz, " $[O]$ fficium é Führertum entendido como leitourgia, como serviço prestado ao povo." Agamben relaciona o título, o ano da publicação e um trecho da obra ${ }^{14}$ com a situação da Alemanha à época. Curiosa é a relação que mais um de alemão estabeleceu com esta obra, sempre em um sentido de reforço à autoridade: por um lado, a autoridade política; por outro, o dever abstrato, impessoal, mas subjetivamente cogente.

O officium, segundo Cícero, enquanto dimensão entre a moral e o direito, coloca como questão maior "a capacidade puramente humana de governar a própria vida e a dos outros." (AGAMBEN, 2013a, p. 83) Esta questão é pautada por uma releitura da teoria das virtudes:

O De officiis apresenta-se, assim, como um tratado sobre as virtudes: não somente o primeiro livro é constituído essencialmente de uma análise da justiça, da beneficência, da magnanimidade e da temperança, mas também, nos dois livros sucessivos, amplo espaço é dedicado à análise da liberalidade e da fidelidade à palavra dada e à definição da virtude em geral. Se o officium é o que torna governável a vida dos homens, as virtudes são o dispositivo que permite a esse governo atuar. Esse tratamento dos oficios como virtude e das virtudes

\footnotetext{
${ }^{12}$ Assim, segundo ele, "[O] officium não é uma obrigação jurílica ou moral nem uma pura e simples necessidade natural: é o comportamento que se espera entre pessoas que são ligadas por uma relação socialmente codificada, mas cuja cogência é bastante vaga e indeterminada para poder ser exposta - ainda que de modo derrisório - mesmo para um comportamento que o senso comum considerava evidentemente ofensivo do pudor. Tratase, em última análise, para repetir a terminologia de Zenão, de uma questão de 'plausibilidade' e de 'coerência': o officium é o que faz com que um indivíduo se comporte de modo consequente; como prostituta é-se prostituta, como vilão é-se vilão, mas também como cônsul é-se cônsul e, mais tarde, como bispo é-se bispo." Ambas as citações in AGAMBEN, Giorgio. Opus Dei: Arqueologia do Ofício. São Paulo: Boitempo Editorial, 2013, p. 80.

${ }^{13}$ Ainda, "[S]e o homem não vive simplesmente a sua vida como os animais, mas a 'conduz' e 'governa', o officium é o que torna a vida governável, aquilo através do que a vida dos homens é instituída’ e formada'. Decisivo é, porém, que, desse modo, a atenção do político e do jurista se desloque da realização dos atos singulares para o 'uso da vida' em seu conjunto, que o officium tenda, assim, a identificar-se com a 'instituição da vida' como tal, com as condições e os status que definem a própria existência do homem na sociedade." Ambas as citações in AGAMBEN, Giorgio. Opus Dei: Arqueologia do Ofício. São Paulo: Boitempo Editorial, 2013, p. 82.

14 "Cícero aderia ao ideal da época dos Cipiōes, sonhava com um guia [Führer], com um novo Cipião, que, por intermédio da autoridade de sua pessoa, teria podido despertar à nova vida a antiga constituição romana e o bom tempo antigo [...] a época da libera res publica, na qual um homem político podia guiar o estado apoiando-se somente no amor e na fidúcia do povo, havia desaparecido. Seria necessário um novo líder, que com um poder autoritário, mesmo que fosse ainda nas antigas formas, pusesse fim às lutas de partido. O próprio Cícero sentia que o ideal de liderança política [das Führerideal], que ele reconhecia, não era mais adequado ao presente. Daí o caráter trágico do De officiis.". Esta citação e as anteriores em AGAMBEN, Giorgio. Opus Dei: Arqueologia do Ofício. São Paulo: Boitempo Editorial, 2013, p. 83. A relação entre officium e leitourgia será vista mais à frente.
} 
como ofício é o legado mais ambíguo que a obra ciceroniana devia transmitir ao Ocidente cristão. (AGAMBEN, 2013a, p. 84)

É Ambrósio que traz o termo ciceroniano para o medievo, ao escrever um tratado sobre a ética própria dos sacerdotes, adotando propositalmente o título, a estrutura e os temas da obra de Cícero. ${ }^{15}$ Agamben então afirma que são "três pontos essenciais da estratégia de Ambrósio: 1) transferir para a Igreja e cristianizar o conceito de officium; 2) officium traduz leitourgia e não somente kathēkon; 3) ele remete àquela esfera da operatividade que Ambrósio, com vimos, sabe ser própria do mistério cristão." (AGAMBEN, 2013a, p. 85)

Mas o que seria esta leitourgia? A obra de Agamben inicia-se, na verdade, tratando da relação entre Liturgia e Política. Explica a origem grega da palavra Leitourgia, obra pública, literalmente, que se referia a obrigação assumida pelos cidadãos possuidores de certa renda de prover a uma série de prestações de interesse comum. Estas obrigações tinham caráter pessoal e real e, ainda que não fossem magistraturas (ou seja, os cargos públicos), faziam parte do "cuidado das coisas comuns". Apesar de muitos tentarem se furtar a prestação das liturgias, outros tantos buscavam prestá-las, pois elas serviam para trazer honra e reputação aqueles que às cumpriam. A liturgia não era uma tributação no sentido moderno e técnico da palavra, mas era um tributo prestado por aqueles que podiam a sociedade, sendo esse caráter público da prestação muito ressaltado. ${ }^{16}$

O sistema de liturgias atinge seu auge, segundo o autor, na Roma Imperial, do século II d.C., momento no qual surge a discussão acerca da obrigação dos clérigos de prestarem as liturgias usuais, chamadas em latim munera. Constantino então afirma que:

"aqueles que proviam o mistério do culto divino (divina cultui ministeria impendunt), isto é, aqueles que eram chamados de clérigos, deviam ser de todo isentados de toda prestação pública (ab omnibus omnino muneribus excusentur)” (DRECOLL, 1997, p. 56 apud AGAMBEN, 2013a, p. 15).

A partir desta definição é que cabe refletir acerca dos ditos privilégios do primeiro e do segundo estamentos, ou seja, do clero e da nobreza no que ficou conhecido como Ancien régime. A leitourgia prestada pelo clero é o "mistério do culto divino", enquanto a nobreza deveria ficar a cargo da defesa militar da sociedade bem

\footnotetext{
15 "Na realidade, a referência que se segue imediatamente a Panécio e Cícero e o propósito de dirigir-se aos seus 'filhos no Evangelho', exatamente como Cícero havia se dirigido ao seu filho ('sicut Tullius ad erudiendum filium, ita ego quoque ad vos informandos filios meos [...] quos in evangelio genui' ['Como Túlio (se dirigiu) ao filho a ser ensinado, assim também eu (me dirijo) a vós, filhos meus, a serdes formados [...] os quais gerei no evangelho']), mostra para além de toda a dúvida qual é a estratégia do autor: trata-se de transferir o conceito de officium da esfera profana da filosofia para aquela da Igreja cristã. Ele insere, com esse escopo, um pequeno conto determinante, segundo o qual a composição da obra derivaria de uma sugestão do Espírito Santo." Ele ainda retoma a etimologia do termo de Donato, afirmando "que officium deriva de efficere ("quandoquidem officium ab efficiendo dictum' [visto que se diz officium a partir do efetuar])". Esta "terá sorte entre os autores cristãos, que a retomarão, de Isidoro a Sicardo e Durando, acrescentando a fórmula tautológica (paronímica) 'quia unusquisque debet efficere suum officium’ (que não significa 'cada um deve fazer seu dever', mas antes 'cada um deve tornar efetiva sua condição social').” in AGAMBEN, Giorgio. Opus Dei: Arqueologia do Ofício. São Paulo: Boitempo Editorial, 2013, p. 85.

${ }^{16}$ AGAMBEN, Giorgio. Opus Dei: Arqueologia do Ofício. São Paulo: Boitempo

Editorial, 2013, p. 13-14. Neste sentido, sobre a leitourgia entre os gregos: "O cidadão grego, lembrando que a cidadania excluía os escravos, as mulheres e os estrangeiros, não pagava impostos ordinários porque era livre e porque não precisava. As obras públicas necessárias, bem como as festas e as solenidades religiosas, eram providas através do que se chama liturgia, ou seja, prestações públicas advindas dos cidadãos abastados e o exército, composto de cidadãos, não recebia um soldo, como o exército romano." in KLAUSNER, Guilherme Alfradique. História das Mentalidades Tributárias: Da Antiguidade à Idade Moderna. 2013.90 f. Universidade Federal Fluminense, Niterói, 2013. P. 7.
} 
como do exercício da jurisdição. ${ }^{17}$

Foram os rabinos habitantes de Alexandria, no Egito, que, ao traduzir a Bíblia, escolheram o termo liturgia (Leitourgia, o nome, ou leitourgeō, o verbo) para traduzir o hebraico šeret, que significa "servir", toda vez que ele é utilizado para se referir ao serviço cultual. Assim, o termo liturgia, em uma dupla dinâmica, é transformado no termo próprio do culto público cristão: seu caráter público, e neste sentido especificamente público, ou seja, alinhado a um dos objetivos do Estado Romano, que considera como parte de seus deveres a defesa dos cultos e das consequentes implicações destes cultos na vida dos cidadãos do Império; e seu caráter público, desvinculado do Estado Romano, mas considerado enquanto parte de uma obrigação, e, em contrapartida, benesse, da sociedade para com Deus e para consigo mesma. Isso se diz no intuito de tentar compreender fenômenos sociais da antiguidade tardia a partir de estruturas abstratas modernas.

A partir destas origens, rapidamente liturgia passou a indicar as diferentes obrigações devidas ordenadamente no tempo e no espaço pelas diferentes Igrejas que compunham a Cristandade. O Papa Clemente I foi fundamental, em sua epístola aos Coríntios, para a expansão do conceito de liturgia, da mera prestação pela comunidade, em uma prestação estruturada em um ofício estável e vitalício, objeto de um cânone e de uma regra,

\footnotetext{
${ }^{17}$ Agamben diz, e esta deve ser a nota mais importante deste trabalho, profundamente relacionada com a seção 2.4.3: "A estrutura peculiar do officium se reflete em âmbito canônico nas discussões entre aqueles que consideram o ofício um tipo objetivo e aqueles que o consideram um tipo subjetivo. Segundo os primeiros, o ofício enquanto realidade institucional (ministerium, dignitas, honor) é algo como um elemento objetivo, definido por um esquema normativo de comportamento e substancializado em um titulus e em um beneficium (um provento econômico); para os segundos, ao contrário, é essencialmente um munus, uma atividade desempenhada por um sujeito no exercício de uma função.

Contudo, basta considerar com maior atenção os termos da disputa para constatar que se trata, na realidade, de dois aspectos de um mesmo fenômeno. Certamente a tradição canônica parece sublinhar a prioridade do elemento subjetivo do exercício ("officium datur principaliter non propter dignitatem, sed propter exercitium'); mas que os dois elementos constituam os dois polos de um único sistema, dentro do qual se fundem e definem um ao outro, resulta, para além das oscilações terminológicas, da estreitíssima correlação que os textos estabelecem entre elemento objetivo e elemento subjetivo do officium. Assim, segundo Panormitano, a prelatura é um encargo (honor) que é conferido, porém, não para a honra, mas para o serviço que implica ('non datur propter honorem, sed propter onus'); exatamente por isso, todavia, ao prelado é devida uma honra ('in consequentia praelato debetur honor'); e na decretal que regula o cerimonial da ordenação, sob a rubrica de sacra unctione [da santa unção], lê-se que 'caput inungitur propter auctoritatem et dignitatem, et manus propter ministerium et officium' ['a cabeça será ungida por causa da autoridade e da dignidade e a mão por causa do ministério e do ofício'].

Quando os canonistas modernos, para conciliar as duas posições, concebem o ofício como uma 'situação subjetiva' ou como uma 'competência-dever', que estabelece para um certo sujeito a legitimação (e o dever correlato) para realizar certos atos em virtude de seu encargo ou função, eles não fazem senão confirmar a circularidade que vimos definir a praxe litúrgica.

Compreende-se agora o pertencimento do conceito de causa instrumental, pelo qual Tomás explica a ação sacramental. Assim como o instrumento, por definição, age só na medida em que é movido pelo agente principal, a eficácia da ação ministerial deriva não da pessoa do ministro, mas da função e do ofício que ele desenvolve. Nesse sentido, nas palavras de Varrão, o ministro não age, mas assume e "sustenta" a ação implícita em sua função.

É interessante refletir nessa perspectiva sobre o conceito de 'função', que parece estreitamente conexo ao de ofício (officio fungi; munere, consulatu fungi [funções de ofício; funções do cargo, do consulado]). Foi justamente observado que 'funcionar significa agir como se fosse um outro, na qualidade de alter ego de alguém, pessoa singular ou comunidade. Ter uma função significa não só ser competente para realizar atos dos quais outro leva, em confrontação com o agente, a responsabilidade, mas agir reconhecidamente, claramente como tal'. O termo 'função' nomeia a vicariedade constitutiva do ofício. A analogia com o paradigma da causa instrumental em Tomás, no qual Deus age através daquele que exerce a função sacerdotal, é evidente.” in AGAMBEN, Giorgio. Opus Dei: Arqueologia do Ofício. São Paulo: Boitempo Editorial, 2013, p. 91/2.
} 
onde há um sacerdote (hiereus, sacerdos), termo antes só utilizado pelos cristãos para se referir ao próprio Cristo, tornando essa prestação ministério do sacerdote. Assim a liturgia se torna a obrigação do sacerdote para com Deus e para com a comunidade.

A etimologia dada por Donato e resgatada por Ambrósio relaciona-se com a própria etimologia ciceroniana e aqui será analisada esta relação. Todos os três rejeitam a noção de ofício como derivado de opficium, remetendo-se todos ao efficere.

Efficere significa aliquid ad effectum adducere ['levar algo a efeito']): o officium não é definido pelo opus de um operari, mas por um efficium...”, palavra esta, efficium, que Ambrósio criou para adequar cada um dos conceitos semioticamente ao seu uso, "... de um efficere, é, assim, pura efetualidade." (AGAMBEN, 2013a, p. 87). ${ }^{18}$

Efeito e efetualidade são entes ontologicamente distintos, mas esta distinção tem sido constantemente ignorada pela ontologia ocidental, com impactos que serão analisados mais à frente. Efeitos enquanto consequências de ações e a efetualidade enquanto os efeitos decorrentes do ser, mas não distinguíveis deste são questões que a própria leitura do Kant traz, ainda mais o enfrentamento com a realidade do Estado contemporâneo. Há dignidade própria atribuível ao indivíduo que exerce um cargo público independente do exercício do dever? Inversamente, o exercício do dever resta maculado por características pessoais daquele que o exerce?

Estas questões são fenomenicamente distintivas da realidade do Estado contemporâneo ocidental, porque neste Estado, o indivíduo que exerce um cargo público o faz como o faria um sacerdote católico que celebra uma missa ou confere um sacramento: não só "por Cristo" e "com Cristo", mas "em Cristo". Agamben busca justo neste efficium a raiz de uma doutrina moderna do Dever (lembrando que officiumé realizar o que lhe é mais próprio em face de sua condição social/papel na sociedade). A questão em particular sobre a qual foca o autor, a dos sacramentos ministrados por sacerdote herético ou indigno, já era importante no século III d.C. No Concílio de Trento a distinção entre opus operatum e opus operantis, trazida na encíclica Mediator Dei, já é

\footnotetext{
${ }^{18}$ Tratando da diferença entre efeito e efetualidade, que será valiosa para o desenvolvimento do argumento, Agamben explica: "O debate sobre a polissemia do termo effectus deixa de fato na sombra uma questão decisiva, e esta é se, justamente na oscilação semântica entre 'efeito' e 'efetualidade', não se esconde porventura uma transformação que, para além da história semântica de um termo, concerne antes à história da ontologia, a modalidade mesma do ser que o termo procura nominar. A oposição entre Wirkung e Wirklichkeit, efeito e efetualidade, não é, assim, somente semântica (os dois termos partilham do mesmo tema e da mesma etimologia), mas ontológica. Antes, talvez não se trate de uma oposição, mas de uma indeterminação, que corresponde a uma mutação decisiva da própria conceitualidade da ontologia. Enquanto no vocabulário da ontologia clássica o ser e a substância são considerados independentemente dos efeitos que possam produzir, na efetualidade o ser é inseparável de seus efeitos, ela denomina o ser na medida em que é efetual, produz certos efeitos e, ao mesmo tempo, é determinado por eles. A efetualidade é, portanto, a nova dimensão ontológica que se afirma primeiro em âmbito litúrgico para depois estender-se progressivamente até coincidir na modernidade com o ser enquanto tal. Compreender o significado de effectus nos textos litúrgicos significará por conseguinte confrontar-se com uma transformação na concepção do ser que nos concerne de perto. Porque talvez não tenhamos hoje outra representação do ser que não seja a efetualidade e é essa dimensão que está em questão tanto em termos como Wirklichkeit, realitas, "realidade", quanto na definição do Dasein no $\$ 9$ de Ser e tempo como o ente 'em que a essência jaz [liegt] na existência”" in AGAMBEN, Giorgio. Opus Dei: Arqueologia do Ofício. São Paulo: Boitempo Editorial, 2013, p. 50.
} 
afirmada definitivamente, ou seja, a Igreja confirma seu entendimento de que o sacramento ministrado pelo sacerdote indigno ou herético não carece de validade por isso, porquanto o sacerdote só é meio pelo qual opera Deus, quando do ministério dos sacramentos.

O opus operatum seria a ação sacerdotal quando julgada a partir de seus efeitos e a função que ela desempenha na economia divina, ou seja, uma parcela significativa do todo que compõe o sacramento enquanto ação do Divino sobre o Humano, enquanto o opus operantis (ou operans) seriam as "disposições e as modalidades subjetivas através das quais o agente faz existir a ação", ${ }^{19}$ ou seja, a prática do ritual. Interessante é a conexão desta reflexão, afirmada na escolástica, com a análise do conteúdo da lei eterna em Tomás de Aquino, qual seja, o governo de toda comunidade do universo pela razão divina. Assim, o ritual, enquanto componente do sacramento, realiza o sacramento na medida em que Deus não tem como negar o efeito com base na incapacidade do sacerdote..$^{20}$ Esta noção do poder do ritual, apesar de extremamente racionalizada, se assemelha a de outras tradições religiosas que, com menos elaboração, formularam o mesmo princípio de que a divindade não se pode

\footnotetext{
${ }^{19}$ AGAMBEN, Giorgio. Opus Dei: Arqueologia do Ofício. São Paulo: Boitempo Editorial, 2013, p. 34. O autor explica melhor: "Desse modo, o nexo ético entre o sujeito e sua ação se quebra: determinante não é tanto a reta intenção do agente, mas só a função que a ação desempenha enquanto opus Dei. Como a ação do demônio enquanto opus operatum é desenvolvida a serviço de Deus, também, como opus operantis, se resta maldosa, assim a ação litúrgica do sacerdote é eficaz como opus Dei, mesmo se o sacerdote indigno comete pecado. A liturgia define assim uma esfera particular de ação, na qual o paradigma mistérico da Epístola aos Hebreus (o opus operatum de Cristo grande sacerdote) e aquele ministerial da Epístola de Clemente (o opus operantis Ecclesiae) coincidem e ao mesmo tempo se distinguem. Isso pode ocorrer, porém, somente ao custo de dividir e esvaziar de sua substância pessoal a ação do sacerdote, que, enquanto 'instrumento animado' de um mistério que o transcende, em realidade não age e, todavia, enquanto titular de um ministério, exerce de qualquer maneira uma ação própria. Nesse sentido, se, por um lado (com relação ao mistério e ao opus operatum) ele não é sujeito, mas instrumento, que, nas palavras de Tomás, 'não age em virtude da própria forma', por outro (com relação a seu ministério), mantém sua ação específica, como o machado, no exemplo de Tomás, 'segue sua ação instrumental só exercitando sua ação específica, que é dividir e cortar'. O sacerdote, enquanto instrumento animado, é, portanto, aquele sujeito paradoxal, a quem compete o 'ministério do mistério'. Enquanto, nele, o opus operantis pode coincidir com o opus operatum somente na medida em que se distinguem e podem se distinguir somente na medida em que desaparecem nele, pode-se dizer que (na terminologia dos atos linguísticos) sua felicidade é sua infelicidade e sua infelicidade é sua felicidade. É significativo que a encíclica Mediator Dei de 1947 manifeste particular atenção ao problema da distinção entre opus operatum e opus operantis Ecclesiae e procure de todo modo minimizar o problema da sobra (discrepantia) que permanece entre eles. Recita o texto sob o título Falsas oposições para rejeitar inventadas no nosso tempo: $\mathrm{Na}$ vida espiritual não pode haver nenhuma discrepância ou contraposição [discrepantia vel repugnantia] entre a ação divina que, para perpetuar nossa redenção, infunde a graça nas almas e a obra laboriosa e colaboradora do homem [sociam laboriosamque hominis operam], que não deve tornar vão o dom de Deus. Portanto entre a eficácia do rito exterior dos sacramentos, que se produz ex opere operato, e a ação meritória daqueles que os concedem ou recebem, que denominamos opus operantis; igualmente, entre as orações públicas e as privadas, entre a vida ascética e a piedade litúrgica; e, enfim, entre a jurisdição e o magistério legítimo da hierarquia eclesiástica e o poder que se diz propriamente sacerdotal, que se exerce no sacro ministério. Contudo, enquanto o texto confirma várias vezes que, ao menos no que concerne aos sacramentos, a eficácia do culto se produz 'sobretudo e em primeiro lugar ex opere operato', não é claro como se deva entender a necessidade da opus operantis Ecclesiae que a encíclica se predispõe a afirmar. É possível reconhecer aqui o modelo teológico daquela cisão e, ainda, cooperação, entre a atividade e a iniciativa necessária do militante político, de um lado, e as leis dialéticas da história que lhes garantem a eficácia, de outro, que assinalou permanentemente a praxe da tradição marxista."

${ }^{20}$ Esta afirmação, acerca da capacidade de Deus de voluntariamente resistir a sua própria razão, foi motivo de certa polêmica na Igreja, promovida pela obra de Duns Scotus.
} 
furtar ao cumprimento de uma obrigação que lhe é atribuída pela perfeita execução do ritual. ${ }^{21}$ A diferença em relação a algumas outras tradições é que, no Cristianismo, a própria Divindade, feito Homem, estabeleceu os rituais pelos quais se vincularia, quais sejam, os sacramentos. Sem nunca deixar de ser a prestação pública de culto, cada vez mais o papel cultual do sacerdote é intelectualmente desenvolvido, conforme diversos questionamentos vão aparecendo, pelos teólogos da Igreja.

Analisando a classificação das artes in actu (que tem em si seu fim - ou seja, terminados seus atos, não a obra que destes subsista) e as artes in effectu (cujo fim é uma obra) de Quintiliano, comparando-as com as definições de práxis e poiēsis de Aristóteles, e a desenvolvida por Ambrósio, a qual, trabalhada sobre a criação do mundo, apesar de fazer referência a obra de Quintiliano, foca no sintagma operis munus - não na obra em si, mas nesta como vinculada a ação criadora -, faz Agamben perceber claramente a alteração que já se dá entre os dois pensamentos acerca da temática da distinção efeitoefetualidade. Esta alteração se dá no papel atribuído a ação como ofício de alguém, através do conceito de operationis officium, mais do que a obra resultado da poiēsis. Há a instauração de um espaço de indistinção entre dois possíveis focos desta poiēis: a ação de alguém que resulta em uma obra - o foco maior na obra de Quintiliano e Aristóteles - e a obra que é resultado da ação de alguém - a obra que "quase perde" sua distinção ontológica de seu criador, bem como o ser perde também a sua que o distingue da obra - em Ambrósio. A problemática gerada por esta indistinção gera consequências profundas, levantando questões que se espraiam por campos tão diversos quanto a estética ${ }^{22}$ e a política.

O ser criador nesta análise de Ambrósio é aquele que faz, é sua própria operatividade, e o autor ressalta o quão interessante é esta obra ser referida a partir de conceitos como munus e officium. Em pleno acordo com uma constante do pensamento católico, Deus não poderia ter deixado de criar o mundo, porquanto servo de sua razão,

Lei Eterna do universo. Aqui está o "obscuro precursor" de todas as questões já tratadas, segundo o

\footnotetext{
${ }^{21}$ Agamben também o percebe e, ao tratar um texto de Suárez que afirma trazer o conceito de absoluta instrumentalidade dentro da liturgia sacramental e que afirma ser "o paradigma das tecnologias modernas", afirma, partindo da premissa contrária da que aqui foi trazida, qual seja esta, da originalidade e significação do desenvolvimento de uma liturgia sacramental para uma conceituação filosófica da tecnologia, que "[A] técnica moderna não deriva apenas do sonho dos alquimistas e magos, mas também, e de forma verossímil, daquela operação 'mágica' particular que é a absoluta e perfeita eficácia instrumental da liturgia sacramental.” in AGAMBEN, Giorgio. O Uso dos Corpos. São Paulo: Boitempo Editorial, 2017, p. 100. Agamben revisita o tema em seu The Kingdom and the Glory, pgs. 224 e ss. (ponto 8.16), quando compara os trabalhos de Mauss e Levy acerca do ritual (sacrificial, no caso) como criador da divindade. Esta teoria, que tem forte embasamento, é popularizada em diversas obras, dentre as quais o livro American Gods, de Neil Gaiman, que tem como premissa a relação entre a existência de um deus e o culto que lhe é devotado (i.e. o esquecimento do culto - entendido aqui especificamente como prática ritualista - leva à morte do deus). Da mesma forma, a manutenção do culto aos antepassados e aos deuses familiares é o fundamento da adoção em Roma na Antiguidade, como será citado mais à frente de forma mais específica. Isso se diz para mostrar a permanência de padrões de pensamento através do tempo e a importância do diálogo da Academia com a cultura popular com o intuito de esclarecimento conceitual.

${ }^{22}$ Neste sentido, não é de todo inadequado apontar a distinção entre pensamento artístico clássico e romântico feita por Irving Babbitt em seu Rousseau e o Romantismo. Nesta obra, o autor busca estabelecer o caráter profundamente embebido de um imaginário romântico de Rousseau, e sua posterior influência política e artística. O romântico representaria a busca na obra do reflexo do artista e não, como o classicista, a revelação de verdades transcendentes através da obra artística. A comparação entre esta
} 
Agamben. ${ }^{23}$

Agostinho, contestando Pelágio, ${ }^{24}$ sintetiza o pensamento de seu adversário na máxima "posse in natura, vele in arbítrio, esse in effectu" ("o poder na natureza, o querer no arbítrio, o ser no efeito"), mas, ao recapitular este pensamento, já demonstra que seu próprio pensamento não mantém de forma tão absoluta as distinções entre ser e efeitos por este ser gerados: "Nam cum [Pelagius] tria distinguat [...] possibilitatem, voluntatem, actionem" ("Pois, embora Pelágio distinga três coisas... possibilidade, vontade, ação") (AGAMBEN, 2013a, p. 56). Aqui ação, ser, obra e efeitos da ação se confundem. É esta espécie de discurso que revela uma cisão já existente entre a ontologia tradicional e uma nova ontologia, na qual o ser trazia em si possibilidades de ser-efeito que configuravam um próprio novo indivíduo abstrato quando anteposto ao fenômeno no mundo real. Assim a pergunta retórica "que é um sacerdote?" e a pergunta “que deve fazer um sacerdote?" se confundem mentalmente e se tornam uma só: "que deve ser um sacerdote?" Não seria de todo incomum responder a primeira pergunta com a frase "um sujeito que reza missas/que é responsável pelo culto", uma resposta absolutamente correta, mas não para essa pergunta.

Segundo o autor, esta forma de pensar, que ele denomina ontologia da efetualidade, alcança sua plenitude no pensamento escolástico em Berengário de Tours, Hugo de S. Vitor e Tomás de Aquino, em especial quando é aplicada à questão sacramental, coma teoria do sacramento como sinal. Segundo esta teoria, o sacramento não seria mais tão somente sinal, declaração da própria operação realizada através do sacerdote por Deus, mas a própria eficácia, como se pode extrair do já dito acerca do poder do ritual para obrigar a realização do ato pela divindade. No entanto, aqui é a mera palavra de Cristo que tem caráter efetual, ou seja, contém em si o poder de sacramentar. Ambrósio já dera a pedra fundamental, no entanto, ao utilizar a palavra operatorius, operativo ou efetual, para tratar do verbo de Cristo, a oração eucarística, as libações sacramentais, com base no poder criador que o Verbo divino detém, segundo a Bíblia.

Em seu Exameron, Ambrósio parece estar ciente de sua criação:

\footnotetext{
distinção e a do pensamento de Ambrósio e de Quintiliano, ressalvadas todas as gigantescas peculiaridades de cada um dos pensamentos, poderia ser proveitosa para a construção de uma crítica estética mais profunda.

${ }^{23}$ AGAMBEN, Giorgio, Opus Dei: Arqueologia do Ofício. São Paulo: Boitempo Editorial, 2013, p. 54. Aponta o autor, ainda, quão mais distante é Cícero da concepção aristotélica da distinção entre práxis e poiēsis: "N Na realidade, o paradigma de ação que está em questão aqui é bastante próximo daquele que se assemelha ao das artes actuosae, como a dança e o teatro. Em uma passagem de De finibus, que contém talvez a mais precisa definição de efetualidade, Cícero, comparando o officium da sabedoria aos gestos e movimentos do ator e do dançarino, escreve que, nestes, 'o fim, isto é, a efetuação da arte não deve ser procurada fora, mas nela mesma [in ipsa insit, non foris petatur extremum, id est artis effectio]'. O fim não é aqui uma obra externa (como na poiēsis) nem mesmo coincide, como poderia parecer à primeira vista, com a própria ação (como na praxis). Ele coincide, de fato, com o ato apenas na medida em que este é a efetuação (effectio) de uma arte. Decisivo aqui é que fornecer um novo paradigma ontológicoprático seja uma operação artística especial (a teatral e coreográfica), que não esteja em questão, assim, um paradigma ético, mas um paradigma técnico particular.

Enquanto Aristóteles via realmente a obra (ergon) como telos da poiēsis do artesão ou do artista, aqui, por meio do paradigma das artes performativas, como a dança e o teatro, que são por definição sem obra, o telos não é mais a obra, mas a artis effectio."

${ }^{24}$ A celeuma deles não se debruça sobre este ponto de tensão entre efeito-efetualidade.
} 
[...] outros [...] como Aristóteles [...] puseram dois princípios, a matéria e a forma e com estes, como terceiro, aquilo que se chama o operativo, a que compete a operação efetiva" ("dua principia ponerent, materiem et speciem et tertium cum his, quod operatorium dicitur, cui suppeteret [...] efficeré). (AMBRÓSIO, 1, 1, 1 apudAGAMBEN, 2013a, p. 59)

Operatorium, neste caso, segundo Agamben, designaria no extrato um terceiro entre a matéria e a forma, entre a potência e o ato. Neste sentido, Agostinho e Isidoro passariam a usar, como Ambrósio, a expressão operatoria virtus ou operatoria potentia para se referir à potência divina. Ambrósio e seus sucessores tinham em mente uma dimensão ontológica que não seria simplesmente potencial nem somente atual, mas verdadeira potência que se dá realidade através de sua própria operação.

O vocábulo operatio passa a fazer parte do instrumental da teologia trinitária, onde o Logos passa a ser entendido como operação interna do ser divino. Citando Mário:

Vitorino, apresenta, de forma a concluir-lhe o pensamento, fórmula: "o ser contém em seu interior uma operação, é essa operação e, ao mesmo tempo, é indiscernível do Pai" (AGAMBEN, 2013a, p. 60). Há também a tecnicização do termo operatio para se referir a operatividade da ação litúrgica, diferente do opus no qual ela se materializa, diz Agamben.

Estes todos são instrumentos intelectuais usados pelos primeiros cristãos para explicar relações distintas, entre Pai e Filho, entre o Padre e Cristo, entre o Padre e o Fiel, entre o Fiel e Cristo, que Agamben analisa paralelamente para mostrar como as questões surgidas a partir da abordagem destas relações obtiveram soluções semelhantes, guardadas as devidas proporções, a ponto de usarem o mesmo vocábulo, vocábulo de importância não tão significativa na filosofia aristotélica, mas que dela surgiu, e que acabou adquirindo importância fundamental na civilização ocidental, em especial no Ocidente contemporâneo.

Filosoficamente, há, então, a transição do foco que, na ontologia clássica, era voltada para a obra, como resultado de uma operação, para a operação em si, porque a operação é meio de manifestação de um poder superior ("Uma coisa é a obra, outra coisa é a operação [aliud opus, aliud operatio]: a obra pertence à água, a operação ao espírito santo" - AMBRÓSIO, 1994, 1, 15 apudAGAMBEN, 2013a, p. 60).

Segundo Agamben, Tomás de Aquino tem, na doutrina da efetualidade sacramental, o papel de acrescentar uma quinta causa às tradicionais quatro causas de Aristóteles, qual seja, a causa instrumental. "O que define a causa instrumental e sua dúplice ação, na medida em que age segundo sua natureza só enquanto é movida por um agente principal, que a usa como instrumento” (AGAMBEN, 2013a, p. 61). Tomás avança para afirmar que o homem é justificado por Deus através dos sacramentos, que são "sinais que efetuam o que significam". Esta teoria de Tomás de Aquino é particularmente importante porque revela uma clareza no discernimento da comunhão de um aspecto existencial íntimo do homem com sua manifestação externa que é fundamental para a conclusão à qual se pretende chegar com o presente estudo.

O sacerdote, retornando ao tratamento da causa instrumental de Aquino, é instrumento de Cristo quando ministra os sacramentos, fazendo as vezes de Cristo, ou, como dito pelo próprio Tomás de Aquino, 
agindo "na pessoa de Cristo", pois nesta operação, apesar dele não ser necessário para Deus enquanto instrumento, ele se justifica, e o homem se justifica ao receber o sacramento. Não há representação jurídica, diz Agamben, mas uma vicariedade constitutiva, que se refere ao sacerdócio e não ao indivíduo que exerce o ministério.

Neste sentido, não é necessário sequer que o sacerdote seja uma boa pessoa, porquanto é indiferente, por exemplo, "que o corpo do médico, que é instrumento de uma alma que possui a arte médica, seja saudável ou doente ou que o tubo por onde passa a água seja de prata ou de chumbo" (Tomás de Aquino, Summa Theologica, III, qu. 22, art. 4 apudAGAMBEN, 2013a, p. 62). Na falta de melhores palavras, Agamben expõe conclusão à qual o caminho que percorre em seu livro levará: "[A]través do paradigma da vicariedade e da causa instrumental, é introduzido na ética o princípio, que encontrará ampla aplicação no direito público, segundo o qual o caráter moral ou físico de um agente é indiferente para a validade e a efetualidade de sua ação" (AGAMBEN, 2013a, p. $63)$.

Agamben afirma, então, que uma das hipóteses fundamentais para qualquer pesquisa genealógica da modernidade é esta, ou seja, a operatividade como única experiência do ser, fundada nesta ontologia efetual, que substituiu progressivamente a ontologia clássica.

Neste sentido, é importante analisar alguns apontamentos feitos em obras jurídicas nacionais. O Professor e Ministro do Supremo Tribunal Federal Luís Roberto Barroso (BARROSO, 2012) tenta definir o conceito de dignitas a partir do mundo romano e fazer uma espécie de genealogia do conceito. Mostra como há uma ruptura a partir de certos marcos históricos (BARROSO, 2012, p. 131-5) e ao final, descrevendo os passos de uma evolução, afirma que os homens todos, "com a dose adequada de idealismo e determinação política" (BARROSO, 2012, p. 195) serão nobres, e, mais a frente ainda, poderão almejar ser deuses.

A avaliação do professor, dotada de um idealismo por ele mesmo reconhecido, não tem como fim ser literal. O que está em questão é o tratamento jurídico recebido por aquele indivíduo, que deve ser apto a atender suas demandas existenciais, para concretizar a dignidade humana. No entanto, é na atualização do vocabulário que reside a importância da virada ontológica que se dá, segundo Agamben, já a partir dos primeiros séculos da Igreja, mas que, como se verá, transborda a o pensamento teológico e influencia diversos pensadores de viés reflexivo menos teológico.

A dinâmica desta análise, ou seja, a possibilidade de tornar-se algo que já se é, a operação que é indiscernível do ser, não é um elemento da filosofia do mundo antigo, précristão, mas da filosofia do mundo novo, cristão. Agamben, no entanto, afirma, que ela já estava presente, de forma latente, no início da ontologia ocidental: "a tendência a reduzir ou, pelo menos, a indeterminar o ser no agir." (AGAMBEN, 2013a, p. 66) Assim, o homem é não um ser que é, mas um ser que age, no sentido mais lato do termo. Já em Aristóteles, dynamis e energia são 
modos em que o Ser se diz. Afirmado o primado da energia, está lançada a base da ontologia da efetualidade, ou seja, uma ontologia onde o Ser só é enquanto posto-em-obra, um Ser que deve ser realizado. Este caráter, em si, não é propriamente aristotélico, derivando dos trabalhos influenciados pelo platonismo e da teologia cristã, quando postos diante do aristotelismo, segundo Agamben. A partir daí se pode entender a discussão, nos tempos modernos, do momento do surgimento do ser, já presentes em Agostinho. É o Ser que se torna, pelo surgimento da alma racional, pela encarnação da alma, pela capacidade de sofrer.

Da mesma forma, esta capacidade dinâmica não se restringe ao indivíduo. A similitude da discrepância no campo da ontologia e no campo político entre antigos e modernos é gigantesca. Assim, a compreensão do Direito Romano, por exemplo, exige, para entende-lo enquanto fato social, a capacidade de assimilação de um Weltanschauung absolutamente diverso do atual, no qual, para celebrar-se um contrato, uma certa fórmula deveria ser falada, sem erros.

\section{A TÉCNICA E O TRABALHO COMO DEFINIDORES DA MODERNIDADE (HEIDEGGER - JÜNGER - AGAMBEN)}

Segundo Agamben, Heidegger, em curso de 1941 sobre "A metafísica como história do ser" aponta o momento da transição da pura energeia aristotélica para actualitas (Agamben identifica o conceito de hipóstase em Plotino e em posteriores autores cristão com o conceito de posição-em-obra, ${ }^{25}$ responsável o primeiro pela superação das distinções entre as categorias da ontologia clássica - ser, praxe, potência e ato - através da utilização por Plotino do termo hoion - quase), realidade, ${ }^{26}$ na "passagem da conceitualidade grega para a romana", através do influxo da concepção cristã de criação. Agamben, como demonstrado, discorda, e prova que, mais que o conceito de criação, é a ideologia e prática da liturgia sacramental que reconfiguram a estrutura estática, conceitualista e ritualística dos antigos em uma estrutura aberta ao desenvolvimento ideológico dinâmico, indeterminado, onde o conceito de vontade assume uma função central (AGAMBEN, 2013a, p. 67 e ss.).

Heidegger e Agamben debatem, então, a questão da técnica, sem dúvida fundamental para as questões tratadas neste trabalho, e através deste debate, no qual Heidegger afirma "a essência da técnica como produção e disposição e a Gestell como a segurança do real sobre o modo da disponibilidade", Agamben afirma a tese de que a essência metafísica da técnica deve ser buscada nesta enquanto governo e oikonomia, em última e extrema instância, unicamente, gestão de homens e de coisas.

Gestell, para Heidegger, é a essência da Tecnologia, segundo Agamben, enquanto modo de vida do homem contemporâneo. Significa, literalmente "Enquadramento" e seria, de forma extremamente simplificada, a

\footnotetext{
${ }^{25}$ A ação terminada de pôr-em-obra. Conceito heideggeriano, Ins-Werk-setzen.

${ }^{26}$ Heidegger utiliza-se da tradução da escolástica tardia, não mencionando termos fundamentais na busca de Agamben, effectus e
} vol.11, no. 02, Rio de Janeiro, 2018. pp. 1172- 1267 
forma de apresentação do real para o homem contemporâneo, o real que só é real enquanto científico, técnico, tecnológico, enfim. É o objeto de sua obra Die Frage nach der Technik. A questão que se analisará brevemente tem alguma importância enquanto ponto de reflexão e deve abrir novos questionamentos sobre o significado da modernidade e do real.

Heidegger teve uma grande polêmica em sua vida, que foi sua associação ao Nazismo. Agamben opina, em sua obra Homo Sacer, que é na relação entre homem e tecnologia que o pensamento de Heidegger e o nazismo se aproximam. Heidegger escreveu em sua Introdução à Metafísica:

"As obras que estão sendo divulgadas hoje em dia como a filosofia do nacional-socialismo nada têm a ver com a verdade e grandeza interior deste movimento (ou seja, o encontro entre a tecnologia global e o homem moderno); Estas obras foram todas escritas por homens pescando nas águas turbulentas dos 'Valores' e das 'totalidades". ${ }^{27}$

Então, para Heidegger, a verdade do Nazismo, bem como a razão de sua grandeza, seria o encontro da tecnologia com o homem, que permitiria a superação das contingências naturais na definição do sentido da vida humana.

Neste livro, de 1950, Heidegger respondia a Splenger, que em 1931 havia afirmado em seu livro $O$ homem e a técnica que a técnica não poderia ser compreendida a partir do instrumento, afirmando "um nexo essencial entre técnica e instrumentalidade". Para Heidegger "a técnica nada mais é do que um agir humano voltado para um fim", e "a instrumentalidade nada mais é do que uma forma de causalidade, e só uma correta compreensão dela pode permitir o acesso à verdadeira natureza da técnica". Se causar "significa levar algo do não ser para o ser, ou seja, é uma forma daquilo que os gregos chamam de poiesis" e "[E]sta é, por sua vez, explicada como um pro-duzir com base na latência na direção da ilatência, da não-verdade na direção da verdade, no sentido grego de a-letheia, 'desvelamento", então a técnica é "um modo eminente desse desvelamento e, como tal, pertence ao destino histórico do Ocidente". A técnica então não deve ser olhada a partir unicamente da perspectiva da instrumentalidade. $\mathrm{O}$ instrumento sim, é um modo de causalidade, mas a técnica é um destino de um desvelamento (AGAMBEN, 2017, p.91).

Heidegger vislumbra nela, então, "segundo uma de suas citações preferidas de Hölderlin, tanto o perigo quanto a salvação" (AGAMBEN, 2017, p. 91). Mas para o mundo clássico, este destaque da técnica e da instrumentalidade é impossível. A técnica e a instrumentalidade, a função mesmo, tudo isso, em Aristóteles,

operatio, traduções mais antigas do termo grego energeia.

${ }^{27}$ HEIDEGGER, Martin. Einführung in die Metaphysik. Tübingen: Max Niemeyer, 1962. (An Introduction to Metaphysics. Trans. Ralph Manheim. New Haven, Conn.: Yale University Press, 1959.), p. 152 apud AGAMBEN, Giorgio. Homo Sacer: Sovereign Power and Bare Life. Stanford: Stanford University Press, p. 88. Agamben complementa: "Da perspectiva de Heidegger, o erro e a traição do nacional-socialismo em sua 'verdade interior' consiste em transformar a experiência da vida factual em um 'valor' biológico (daí o desprezo com que Heidegger se refere repetidamente a Rosenberg). Embora a maior conquista do gênio filosófico de Heidegger fosse ter elaborado as categorias conceituais que impediam a facticidade de se apresentar como um fato, o nazismo terminou com o encarceramento da vida factual em uma determinação racial objetiva e, portanto, com o abandono de sua inspiração original." 
pertence ao ambiente doméstico. ${ }^{28}$

Segundo Aristóteles, a liberdade, elemento fundamental para a participação política, impedia a submissão do homem político ao império da necessidade. ${ }^{29}$ Da mesma forma, técnica e escravo, ambos são sinais da submissão à necessidade e, consequentemente, da ausência de liberdade. Assim, Agamben observa que, apesar de Aristóteles nunca ter negado a condição humana do escravo, sua antropologia sempre foi a antropologia do homem livre, de forma que a "reemergência da figura do escravo na do trabalhador moderno apresenta-se, portanto, segundo o esquema freudiano, como um retorno do recalcado em forma patológica." (AGAMBEN, 2017,p. 39)

O apoio de Heidegger ao Nazismo, cabe agora reformular, se deu a partir da visualização da interação da dimensão política com a dimensão técnica, como um reacionarismo moderno. ${ }^{30} \mathrm{O}$ autor, se recusava "explicitamente, em Sein und Zeit, a apresentação de um 'ideal de existência com conteúdo", permitia, através de sua análise ôntica, a eleição como inimigo de "um tipo concreto de sociedade política", qual fosse, a sociedade liberal e cosmopolita. ${ }^{31}$

Se a análise existenciária, considerada num plano estritamente ético, deixava a resolução indeterminada e sem conteúdo, esta mesma análise adquire, considerada no plano político, o aspecto mais concreto de uma decisão para a ultrapassagem da 'vida pública' de uma sociedade liberal e para a sua substituição por uma

\footnotetext{
${ }^{28}$ Agamben se utiliza do escravo para exemplificar a questão. "A atividade do escravo foi muitas vezes identificada com aquilo que os modernos chamam trabalho. Essa é, como se sabe, a tese mais ou menos explícita de Arendt: a vitória do homo laborans na modernidade e o primado do trabalho sobre as outras formas de atividade humana [...] implicam, na realidade, que a condição do escravo, a saber, daquele que está inteiramente ocupado com a reprodução da vida corpórea, com o fim do ancien régime, tenha se estendido para todos os seres humanos. Não restam dúvidas de que o trabalhador moderno se assemelhe mais ao escravo do que ao criador de objetos (com quem, segundo Arendt, a modernidade tende a confundí-lo) ou ao homem político, e Cícero já afirmava que, para aqueles que vendem o próprio trabalho, a compensação é o 'salário da escravidão' (auctoramentum servitutis De Officiis, I, 42, 150);" in AGAMBEN, Giorgio. O Uso dos Corpos. São Paulo: Boitempo Editorial, 2017, p. 36.

29 "Hannah Arendt lembrou a diferença que separa a concepção antiga da escravidão daquela dos modernos? Enquanto para estes o escravo é um meio de proporcionar forçatrabalho a preço baixo com o objetivo de lucrar, para os antigos tratava-se de eliminar o trabalho da existência propriamente humana, que era incompatível com ele e que os escravos, assumindo-o para si, tornam possível 'Dado que os homens são submetidos às necessidades da vida, podem ser livres unicamente se sujeitarem outros, obrigando-os pela força a suportar em lugar deles aquelas necessidades.' [...] O fato é que o escravo, embora excluído da vida política, mantém com ela uma relação totalmente especial. Ele representa uma vida não propriamente humana que possibilita aos outros o bios politikos, ou seja, a vida verdadeiramente humana. E se o humano é definido para os gregos por intermédio de uma dialética entre physis e nomos, zoè e bios, então o escravo, assim como a vida nua, está no limiar que os separa e une." in AGAMBEN, Giorgio. O Uso dos Corpos. São Paulo: Boitempo Editorial, 2017, p. 38.

${ }^{30}$ Esta definição não é absoluta, mas é aceita em alguns círculos. Há aspectos românticos de rejeição da modernidade no pensamento de Heidegger - Lucáks e Bloch os identificam, associando o filósofo alemão também a Ernst Jünger, como será feito mas é um romantismo fascista e reacionário. Löwy e Sayre relembram a todo momento, em sua obra Romanticism: Against the Tide of Modernity, a adesão de Heidegger ao Nazismo a partir de sua adesão à modernidade ou, mais propriamente, ao papel da técnica na modernidade.

${ }^{31}$ Se a 'vida pública' do 'a gente' era essencialmente alienante, esta consistiria numa sociedade liberal e cosmopolita, assente num 'falatório' permanente (Gerede), numa curiosidade incessante, numa preocupação permanente com a criação de um mundo seguro, pacificado, previsível e instrumentalizado, cuja essência se encontrava justamente na distracção tranquilizante do homem em relação à sua essência. [...]" in FRANCO DE SÁ, Alexandre. A Política sobre a Linha: Martin Heidegger, Ernst Jünger e a Confrontação sobre a era do Niilismo. Covilhã: LusoSofia Press, 2008, p. 26.
} 
comunidade enraizadora. ${ }^{32} 33$

Quando o Nazismo ascende ao poder na Alemanha, Heidegger vê então a concretização de seu ideal de comunidade enraizadora, somado à roupagem moderna conferida pela técnica - não tanto uma rejeição do moderno, mas da modernidade..$^{34}$

A discussão do papel e do status do trabalhador estava em voga no período, e um dos que nela participaram foi o autor Ernst Jünger, que, na mesma época, fez uma proposição semelhante a de Heidegger em sua obra, ${ }^{35}$ ao tratar do trabalhador como um Tipo que, como o Soldado do Front (Frontsoldat), encarna uma

${ }^{32}$ FRANCO DE SÁ, Alexandre. A Política sobre a Linha: Martin Heidegger, Ernst Jünger e a Confrontação sobre a era do Niilismo. Covilhã: LusoSofia Press, 2008, p. 26. O autor complementa, na mesma página, em nota de rodapé: "Em Sein und Zeit, Heidegger fala, a este propósito, de uma existência autêntica a partir do enraizamento num povo e na herança (Erbe) que a tradição (Überlieferung) desse povo constitui."

${ }^{33}$ Esta comunidade seria, segundo Heidegger, "capaz de possibilitar ao homem a resolução para a assunção do seu ser-no-mundo como herança, conformando o seu fado singular (Schicksal) com o próprio destino que o seu estar-lançado lhe assinala (Geschick). Segundo Heidegger, o tratamento ôntico da política abordaria então, por um lado, visto negativamente, as condições para o desaparecimento de uma sociedade cuja 'vida pública' consistiria na dispersão pela qual o homem, numa fuga à assunção da sua essência como aí-ser, se esqueceria de si enquanto estar-lançado no mundo, toldado

sempre pela insegurança de um 'estar à morte', e se compreenderia como um sujeito individual dotado de uma existência separada, segura e desvinculada de qualquer destino determinante. E, por outro lado, abarcando-o numa perspectiva positiva, poder-se-ia dizer que a política trataria do aparecimento de uma comunidade em que os homens não se compreendessem como sujeitos desvinculados, mas como singulares que, longe de surgirem como indivíduos separados e atomizados numa existência segura, se assumissem como o 'aí de um ser que ultrapassa a sua individualidade, e cujos fados são já sempre determinados pelo destino da comunidade que os precede e sustenta na sua singularidade" in FRANCO DE SÁ, Alexandre. A Política sobre a Linha: Martin Heidegger, Ernst Jünger e a Confrontação sobre a era do Niilismo. Covilhã: LusoSofia Press, 2008, p. 27.

${ }^{34}$ "O nacional-socialismo emergente surge então para Heidegger como o enquadramento histórico adequado para a tentativa de desenvolvimento de uma 'ôntica política', de uma política meta-ontológica. É no seio deste enquadramento que Heidegger encontrará os textos de Jünger, escritos ao longo dos anos 30 . E é sobretudo nas categorias usadas por Der Arbeiter, às quais Jünger dá claramente o estatuto de conceitos ainda provisórios e pouco fixos, insuficientes para a veiculação da realidade efectiva que pretendem expressar, que Heidegger tentará encontrar a base para a tradução de uma consideração ôntica da política" in FRANCO DE SÁ, Alexandre. A Política sobre a Linha: Martin Heidegger, Ernst Jünger e a Confrontação sobre a era do Nilismo. Covilhã: LusoSofia Press, 2008, p. 29.

${ }^{35}$ Especialmente em Der Arbeiter: Herrschaft und Gestalt. Muitos escritos já foram publicados acerca do diálogo entre Heidegger e Jünger. Alexandre Franco de Sá e Peter Pál Pelbert apresentam, nos trabalhos citados, a relevância do diálogo com Jünger para a obra de Heidegger. Carpeaux acrescenta ao tema uma pequena discussão acerca da figura de Jünger: "Parábolas são os romances políticos de Ernst Jünger. Auf den Marmorklippen (Nos rochedos de mármore), escrito, publicado e proibido pela censura nazista das vésperas da Segunda Guerra Mundial, é a história da luta entre duas potências totalitaristas e diabólicas, presumivelmente a Alemanha de Hitler e a Rússia de Stalin; à guerra sucumbe um idílio em país mediterrâneo, símbolo da velha civilização europeia. Jünger não é propriamente romancista. Não sabe criar personagens vivos, humanos. Mas sabe criar atmosfera, pelas qualidades "mágicas" do seu estilo conciso, sentencioso, elaborado, às vezes afetado. É um romântico que conseguiu, através das suas experiências, disciplinar-se. Menino ainda, fugiu da casa paterna porque não suportou a vida rotineira na Alemanha próspera e bem policiada de antes de 1914, procurando aventuras nas colônias africanas. A guerra chamou-o de volta para a pátria. Lutou heroicamente; foi o mais jovem dos agraciados com a mais alta condecoração militar, 'Pour le Mérite'. Tinha descoberto a vida do soldado na guerra como seu único possível estilo de existência. Descreveu, em In Stahlgewittern (Em tempestades de aço) e Das Wäldchen 125 (O bosque 125) os horrores da guerra técnica como o último ambiente em que ohomem moderno ainda pode aprender e exercer virtudes de cavaleiro medieval, de aristocrata da Renascença, de oficial prussiano, justamente porque sabe que os engenhos técnicos, impiedosos, o consagram à morte certa. Foi esse niilismo heroico, essa fascinação da morte absurda que aproximou Jünger, nos tempos cinzentos da república de Weimar, da filosofia de Heidegger e dos movimentos revolucionárionacionalistas, prénazistas. Grande é sua responsabilidade na preparação ideológica do nazismo. Mas nunca foi nazista. Como aristocrata por instinto, desprezou o movimento bárbaro e seu chefe plebeu. Já antes daquele romance tornara-se suspeito. Seu diário de guerra, Strahlungen (Irradiações), é documento de completo 'détachement', altivez de indiferença, apesar das simpatias 
espécie de vida. O contato com os elementos materiais da tecnologia na atividade produtiva e no front (no caso, na $1^{\text {a }}$ Guerra, na qual Jünger lutou) transforma a vida destes indivíduos, levando-os a superar as distinções individuais (sociais, e as próprias características pessoais que o indivíduo se atribui) derivadas da moral da sociedade burguesa e a consequente instauração de um organismo social que vive em constante estado de mobilização. Mas o trabalhador, por ser o operador do tecnológico, encontra-se indistinto dele, e vê nele a forma de uma sociedade onde não há mais distinções, onde todos são engrenajens. A tecnologia, no sentido de tecnicidade, é a bigorna na qual uma sociedade absolutamente funcionalizada seria forjada.

Como diria Benoist, o trabalhador não é só mais aquele que trabalha, mas "aquele que revela o Trabalho como a lei geral de um mundo que se dedica inteiramente à eficiência e à produtividade, mesmo no lazer e no descanso." ${ }^{36} 37$ É o abandono da "liberdade de", burguesa do século XIX, e a assunção da "liberdade para", social, adequada ao mundo da mobilização total. Mesmo Heidegger expressamente o diz. ${ }^{39}{ }^{39}$ Weber, ao analisar o Estado Moderno, faz interessante afirmação neste sentido, em consonância com o até agora apresentado. Ele afirma que a disciplina do exército é a origem da disciplina em geral. É, portanto, a conceitualização e a

\footnotetext{
ativas para com as conspirações anti-hitlerianas. Não mudou, Der Waldgang (O caminho para as florestas) celebra, como modelo da resistência que se impõe em nossos dias, o arcaico costume islandês dos proscritos de levar nas florestas inacessíveis uma vida solitária como de ciclopes: é um anarquismo germânico, temperado pela fé na poesia das virtudes aristocráticas." In CARPEAUX, Otto Maria. História da Literatura Ocidental. São Paulo: Texto Editores Ltda., 2010, p. 2708.

${ }^{36}$ BENOIST, Alain de. Types et figures dans l'oeuvre d'Ernst Jünger: Le Soldat du front, le Travailleur, le Rebelle et l'Anarque. Apresentação feita em Roma em Maio de 1997. Acessado através da tradução de Greg Johnson, publicada na revista The Occidental Quarterly, vol. 8, no. 3, edição do outono de 2008. Neste sentido: "Nada é mais elucidativo do que, dentro de um mundo no qual o nome do trabalhador possui o significado de uma marca de dignidade e o trabalho é concebido como a sua mais íntima necessidade, a liberdade se apresentar como expressão precisamente desta necessidade, ou, por outras palavras, do que qualquer reivindicação de liberdade aparecer como uma reivindicação de trabalho." in JÜNGER, Ernst. O trabalhador: domínio e figura, trad. Alexandre Franco de Sá, Lisboa, Hugin, 2000, p. 89.

37 "O seu poder e a sua liberdade dependem de que ele se abandone enquanto indivíduo e se conquiste como um tipo (Typus). Por outras palavras, a configuração do homem como trabalhador consistirá na aniquilação, no próprio homem singular, daquilo que é individual e subjectivo. O homem do século XX, o homem que se configura de acordo com o carácter total do trabalho, é então, segundo o Jünger de Der Arbeiter, já não um sujeito que, na sua liberdade indeterminada, pode submeter o mundo ao seu serviço e domínio, mas justamente um objeto mobilizado por um processo movido por uma legalidade intrínseca, um 'sujeito objectivado' cujo poder e liberdade consistirão no despertar em si da 'consciência' quer da necessidade do serviço, quer da inevitabilidade da mobilização." in FRANCO DE SÁ, Alexandre. A Política sobre a Linha: Martin Heidegger, Ernst Jünger e a Confrontação sobre a era do Niilismo. Covilhã: LusoSofia Press, 2008, p. 13.

38 "Como escreve Heidegger: 'O encargo, enquanto nossa missão, é a nossa determinação no sentido originário, é o poder do próprio tempo em que estamos'” in FRANCO DE SÁ, Alexandre. A Política sobre a Linha: Martin Heidegger, Ernst Jünger e a Confrontação sobre a era do Niilismo. Covilhã: LusoSofia Press, 2008, p. 30.

39 "As formulações de Jünger em Der Arbeiter são, na apresentação desta nova configuração da liberdade, absolutamente inequívocas: 'A obediência é a arte de escutar, e a ordem é o estar preparado para a palavra, o estar preparado para o comando que, como o raio de um relâmpago, vai do cume às raízes. Cada um e cada coisa está na ordem feudal e o guia [Führer] é reconhecido em ele ser o primeiro servo, o primeiro soldado, o primeiro trabalhador. Daí que tanto a liberdade como a ordem se relacionem não com a sociedade, mas com o Estado, e que o modelo de cada organização seja a organização militar e não o contrato social” in FRANCO DE SÁ, Alexandre. A Política sobre a Linha: Martin Heidegger, Ernst Jünger e a Confrontação sobre a era do Niilismo. Covilhã: LusoSofia Press, 2008, p. 13.
} 
concretização da ontologia da efetualidade..$^{40}$ Jünger seria um entusiasmado profeta do mundo que viria se não fosse um ponto presente desde sempre em sua obra: a liberdade, como Alexandre de Sá Franco ressalta. ${ }^{41}$

A apropriação, por parte de Heidegger, das categorias de Jünger, assim como sua adesão ao nacionalsocialismo, são ações vinculadas por uma lógica, qual seja, ambas são manifestações de seu pensamento, no sentido de "desobstruir o acesso do homem à sua própria essência enquanto aí-ser, libertando o poder desta mesma essência, a política”, que, para Heidegger, não tinha como fim o poder e a liberdade do indivíduo ou mesmo da comunidade humana "que o situa como já sempre lançado num destino comum", ou, ainda, do trabalhador jüngeriano. É neste ponto que, apesar do uso que faz das categorias jüngerianas, Heidegger se distancia radicalmente de Jünger. Em razão mesmo disso,

"apesar da sua adesão prematura ao nacional-socialismo, ele não poderia deixar de colidir frontalmente com as doutrinas völkisch e racistas que sob o seu regime se desenvolviam” e que, de certa forma, pregavam a liberdade de uma raça, a suposta raça ariana. ${ }^{42} \mathrm{O}$ que Heidegger anseia é a liberdade da essência do homem,

\footnotetext{
40 "O aparelho psicofísico do homem é aqui completamente adaptado às exigências do mundo externo, do instrumento, da máquina ou, em uma palavra, da função, despojado de seu ritmo dado por sua própria estrutura orgânica e submetido a um novo ritmo que, depois da análise sistemática das funções de cada músculo e da criação de uma ótima economia das forças, corresponde perfeitamente às condições do trabalho. Todo este processo de racionalização realiza-se, aqui e por toda parte, sobretudo também no aparato burocrático do Estado, paralelamente à centralização dos recursos materiais sob o poder de disposição do chefe." in WEBER, Max. Economia e Sociedade: Fundamentos da Sociologia Compreensiva, Volume II. Brasília: Editora UNB, 1999. Pg. $361 / 2$.

${ }^{41}$ "Nos textos que se situam em torno de Der Arbeiter, Jünger tinha falado no despertar de uma 'segunda consciência' no homem singular. [...] O 'realismo heróico', a atitude do homem que se assume como trabalhador, consistiria assim, para Jünger, num desdobrar da própria consciência. E é a este desdobramento que Jünger se refere claramente, em Der Arbeiter, ao escrever: 'Manterse dentro desta posição e, no entanto, não se esgotar nela; ser não apenas material, mas, ao mesmo tempo, portador do destino; conceber a vida não apenas como campo do necessário, mas, ao mesmo tempo, da liberdade - tal é uma capacidade que já foi caracterizada como o realismo heróico'. Deste modo, torna-se necessário precisar a concepção da liberdade esboçada por Jünger nos anos 30: esta consistia não apenas na participação do homem singular, enquanto trabalhador, no processo de mobilização total, mas na sua visão consciente e imperturbável dessa mesma participação. Por outras palavras, para Jünger, o homem singular seria livre não na medida em que simplesmente participava, mas na medida em que se punha a si mesmo como participante; não na medida em que era simplesmente objecto, mas na medida em que era um sujeito que se punha a si mesmo como objecto, estando a sua liberdade na assunção por si da sua objectivação por um processo de trabalho mobilizador. Sem este desdobramento fundamental, sem esta cisão entre, por um lado, o homem singular que se assume como trabalhador e, por outro, o trabalhador como o qual o homem singular se assume, não seria possível pensar a liberdade como trabalho, tal como por Jünger é pensada. $\mathrm{E}$ era justamente este desdobramento fundamental que a concepção heideggeriana da essência do homem como aí-ser não poderia deixar de excluir." in FRANCO DE SÁ, Alexandre. A Política sobre a Linha: Martin Heidegger, Ernst Jünger e a Confrontação sobre a era do Niilismo. Covilhã: LusoSofia Press, 2008, p. 40.

42 "Dir-se-ia assim que o liberalismo e o racismo völkisch poderiam divergir na sua representação do sujeito que deveria surgir como o 'valor supremo', como a meta ou o fim que deveria ser servido pela progressiva dominação e mobilização do mundo. Se o liberalismo punha como fim um sujeito individual, considerado como naturalmente desvinculado de qualquer relação, o racismo völkisch estabelecia o mundo como mobilizado em função de um sujeito colectivo, um povo ou uma raça, cuja unidade surgia como tão desvinculada, tão 'livre' (no sentido liberal) como qualquer sujeito individual. Contudo, segundo Heidegger, eles não poderiam deixar de ser, considerados na sua essência, o mesmo. Ambos eram 'humanismos', modos de o homem surgir como o 'senhor do ente', como a meta e o fim da mobilização do mundo, esquecendo-se de que a sua essência, enquanto aí-ser, consiste na pertença a um ser que nele acontece como um 'acontecimento-deapropriação' (Ereignis); a um ser que, tornando-se justamente essência, nele se essencia." in FRANCO DE SÁ, Alexandre. A Política sobre a Linha: Martin Heidegger, Ernst Jünger e a Confrontação sobre a era do Niilismo. Covilhã: LusoSofia Press, 2008, p. 45. Basicamente, tudo que leva em conta o sujeito, para
} 
através da tecnologia (FRANCO DE SÁ, 2008, p. 42), a criação de uma civilização onde o homem funcionalizado vai ser liberto pela significação do trabalho operativo da tecnologia. $O$ trabalho, então, vai ser o que faz pertencer à comunidade, mas que, profundamente tecnicizado, vai abrir os olhos para esta noção de pertença por ser livre da opressão física do trabalho então existente. Uma comunidade de abelhas.

O interessante, no entanto, é que Jünger rapidamente percebe o que esta forma de pensar, de messianismo tecnológico, de ultravalorização do trabalho e do conhecimento técnico, que Heidegger e ele associavam ao nazismo, ${ }^{43}$ mas que é majoritária até hoje, realmente significa, e altera sua descrição do impacto desta na sociedade, justo quando do início da 2a Guerra Mundial. O autor escreve então uma obra, Nos Penhascos de Mármore, que coloca dois irmãos, os herbalistas, que habitam Marina, nome-descrição, contra o Monteiro-Mor, um líder dos bárbaros da Mauritânia, outra localidade do mundo fantasioso (mas com muitas referências ao mundo real). Muitos, inclusive Goebbels, viram nesta obra um ataque ao Nazismo. Jünger já fizera algumas desfeitas a camarilla do partido, que o convidara a ocupar diversos postos, ora honoríficos, ora na administração pública, todos os convites rejeitados.

A obra, mais do que uma alegoria, se insere numa ideia de crítica não só ao comportamento bárbaro dos "inimigos" da civilização, mas de uma postura instrumentalizante do real. A mudança da forma de pensar de Jünger, na verdade, é um aprofundamento de sua compreensão de que, se a técnica abarca tudo, só há uma forma de não ser abarcado, ser emancipado das circunstâncias que o cercam. Os herbalistas, quando o Monteiro-Mor invade Marina, fogem. Mas não é só a fuga que resolve o problema da possibilidade de vida do indivíduo. É possível fazer como Martin Venator, seu personagem de Eumeswil faz - permanecer sob domínio do Condor, mas livre por dentro, estar no centro da roda em movimento e, portanto, imóvel.

\footnotetext{
Heidegger, como principal elemento de uma ordem é liberalismo, ainda que o sujeito seja um sujeito coletivo. Só a centralização da ordem no esse é que supera a falácia do liberalismo e justifica (no sentido de "faz justiça") à existência.

${ }^{43}$ Jünger sabe onde levará este estado de mobilização total (totale Mobilmachung) que caracteriza o mundo da eficiência e da técnica. O resultado necessariamente é "o Estado universal, ou mesmo o Império universal (sic, muito antes de Negri). Uma tal aceleração universal do Estado universal, um tal estilo global de vida, implica uma uniformização das classes, das raças, das estações do ano, do dia e da noite, até mesmo dos sexos. Se o nivelamento imprime uma direção única ou privilegia uma tendência predominante em meio a uma multiplicidade de possibilidades, ao alegar garantir ao homem a segurança, traz precisamente uma ameaça ao que Jünger considera o próprio desse homem: sua imperfeição, sua capacidade de cometer erros. E o autor arremata que tal tendência à unidade não é apenas política, ela 'englobaria toda vida', inclusive aspectos biológicos, em uma aguda intuição sobre o caráter biopolítico desse desenvolvimento." in PELBART, Peter Pál. O Avesso do Niilismo: Cartografias do Esgotamento. São Paulo: n-1 Edições, 2013, p. 137. Agamben concorda com esta análise. Em seu Homo Sacer, afirma que "isso é precisamente o que caracteriza a revolução biopolítica da modernidade, ou seja, a condição em que ainda nos encontramos. E este é o ponto em que o nazismo e o pensamento de Heidegger divergem radicalmente. O nazismo determina a vida desnuda do homo sacer em uma chave biológica e eugênica, tornando-a local de uma decisão incessante sobre o valor e o não-valor, no que a biopolítica se transforma continuamente em tanatopolítica e em que o campo, conseqüentemente, se torna o espaço político absoluto. Em Heidegger, por outro lado, homo sacer - cuja própria vida está sempre em disputa em cada um de seus atos - torna-se Dasein, a unidade inseparável do Ser e das formas do Ser, do sujeito e das qualidades, da vida e do mundo, 'cujo próprio Ser está em disputa em sua própria Existência'. Se a vida, na biopolítica moderna, é imediatamente política, aqui esta unidade, que por sua vez tem a forma de uma decisão irrevogável, se afasta de toda decisão externa e aparece como uma coesão indissolúvel em que é impossível isolar algo como uma vida nua." In AGAMBEN, Giorgio. Homo Sacer: Sovereign Power and Bare Life. Stanford: Stanford University Press, p. 88.
} 
Na ordem existente, na qual o Trabalho é a lei universal e, consequentemente, eficiência e técnica são os paradigmas absolutos de valor, não é só dentro das formas institucionalizadas de política que se deve imaginar que os gatilhos funcionam para a funcionalização do homem. A própria característica do capitalismo de conseguir servirse de qualquer estrutura ordenante para funcionar faz com que, nas mais diversas situações da vida do sujeito, este extremar da busca pela eficiência levem a situações específicas da modernidade.

Sandel, consternado diante da nova eugenia que se delineia como meio reconhecido como válido a partir da quebra de sentidos de bem comum - ou seja, diante de uma sociedade que tem o sucesso como máximo objetivo moral, alerta para os mecanismos de manipulação genética, para as cirurgias de caráter estético e para a melhoria de performance física em sua obra Contra a Perfeição. ${ }^{44}$

\begin{abstract}
44 “Embora a eugenia liberal seja uma doutrina menos perigosa do que a antiga eugenia, ela é também menos idealista. Apesar de toda sua tolice e ignorância, o movimento eugenista do século XX nasceu da aspiração or aprimorar a humanidade, ou promover o bem-estar coletivo de sociedades inteiras. A eugenia liberal se exime de tais ambições coletivas. Não é um movimento de reforma social, mas uma forma de pais privilegiados terem o tipo de filho que desejam e armá-los para o sucesso em uma sociedade competitiva." In SANDEL, Michael J.. Contra a Perfeição: Ética na era da engenharia genética. Rio de Janeiro: Civilização Brasileira, 2013, p. 89. Sobre a possibilidade de convivência entre dois modelos em uma sociedade, um fundado na aceitação dos limites naturais e outro na insurgência contra estes, a partir de uma sugestão da revista Wired sobre a possibilidade de criarem uma liga para jogadores que alterem farmacêutica, cirurgica ou geneticamente, Sandel responde, no mesmo livro: "É difícil dizer se a ópera tradicional e a amplificada ou as ligas de atletas turbinados e as de 'orgânicos' poderiam coexistir por muito tempo. Tanto nas artes quanto nos esportes, as versões tecnologicamente melhoradas de uma prática raras vezes deixam inalteradas as antigas versões; as normas mudam, as plateias ficam desacostumadas e o espetáculo exerce certo fascínio, ainda que nos prive do acesso não adulterado aos talentos e dons humanos." (p. 53). Ainda: "Os esteroides e estimulantes que figuram no debate em torno do melhoramento não são uma fonte de recreação, mas uma tentativa de adequação, uma forma de resposta à demanda competitiva da sociedade para melhorar nosso desempenho e aperfeiçoar nossa natureza. Essa demanda pelo desempenho e pela perfeição anima o impulso de injuriar o que nos é dado. É a fonte mais profunda do problema moral do melhoramento." (p. 72). Interessante é notar que o uso recreacional das drogas é malvisto, enquanto o uso de drogas com impacto até mais danoso sobre o organismo, como as drogas utilizadas para controle do TDA, é estimulado. É justo esta adequação da sociedade a um modelo de eficiência que tem uma faceta intencional e uma faceta não intencional, um que claramente beneficia os proprietários dos meios de produção (mesmo que o Estado não reconheça a propriedade privada e seja ele mesmo detentor das propriedades produtivas, ou qualquer variação neste espectro entre propriedade privada e propriedade pública) e outro que, independente destes estímulos mercadológicos, é assumido como parâmetro de determinação do sucesso de uma pessoa, que, como se verá, é o parâmetro único de uma sociedade que refuta absolutamente qualquer noção de bem comum. Jünger também abordara a questão. Diz Franco de Sá que "[n] uma análise que, nos anos 30, antecipa em larga medida a reflexão sobre fenómenos como a profissionalização no desporto, orientada pela constante ultrapassagem de limites e fixação de recordes, ou como a obsessão pela saúde, pelo training ou pela 'cultura' do corpo e da juventude, Jünger pode escrever: 'Que nestes fenómenos se trata menos de mudanças técnicas do que de um novo modo de vida, isso reconhece-se o mais claramente possível em o carácter instrumental não se limitar à autêntica zona do instrumento, mas procurar submeter também o corpo humano. É esse o sentido do processo peculiar que assinalamos como desporto, e que se deve distinguir dos jogos dos antigos na mesma medida em que as nossas olimpíadas se distinguem das dos gregos. A diferença essencial consiste em que connosco se trata muito menos de uma competição do que de um processo de medição'." in FRANCO DE SÁ, Alexandre. A Política sobre a Linha: Martin Heidegger, Ernst Jünger e a Confrontação sobre a era do Niilismo. Covilhã: LusoSofia Press, 2008, p. 14. O trecho de Jünger também é do Der Arbeiter. O texto do professor Luís Roberto Barroso, se posto lado a lado com as teorias acerca da existência de uma eugenia liberal praticada socialmente no Ocidente hoje, mostra outra faceta desta eugenia, qual seja, a da manipulação genética para a transformação do corpo segundo a vontade do indivíduo fundada em perspectivas identitárias. Conforme o debate acerca das políticas identitárias é popularizado, vê-se cada vez mais o discurso que fundamente a intervenção eugênica passar do topos médico para o topos identitário voluntarista (e é importante denotar este último aspecto, vez que, em regra, a identidade é algo que se nasce com). Um exemplo desta situação, tem sido a questão da transsexualidade, que antes era abordada a partir da perspectiva terapêutica e hoje vê-se cada vez mais abordada a partir da perspectiva da afirmação de uma identidade masculina ou feminina. Se o discurso era antes essencialista, cientificista e objetivo (com base na concepção de naturalidade de uma determinada condição), hoje o discurso é voluntarista (com base na
\end{abstract}


Aqui o que fica claro é que esta união entre o homem e a tecnologia que perpassa a obra de Heidegger e o que ele acreditava ser a ideia do Nazismo, vai além de uma instrumentalização da Natureza externa ao homem, mas envolve o que é a Natureza interna ao homem, os fatores incontroláveis que definem a especificidade de cada indivíduo na natureza. É a eugenia, a negação de qualquer barreira entre homem, natureza e tecnologia. O Gestell não é só o enquadramento do real dentro de uma ética de construção de sentido externa ao homem (sentido político) onde os parâmetros para esta construção de sentido (o real dado) são manipuláveis (construção do real). O Gestell, como na análise de Jünger sobre o trabalhador, não conhece limites, e enquadra o próprio homem, e o homem se faz objeto deste próprio Gestell, deste enquadramento, e é, portanto, e Jünger não chega a esta conclusão, manipulável em sua Natureza interna.

Agamben concorda com Illich quando afirma que é no desenvolvimento do conceito de causa instrumental que se dá o primeiro passo para o desenvolvimento de um estatuto filosófico autônomo para a tecnologia. ${ }^{45}$ Para Agamben, o paradigma da evolução do conceito filosófico do instrumento técnico está "naquele 'instrumento animado’ que é o escravo - a saber, o homem, que ao usar seu corpo, é na realidade usado por outros." (AGAMBEN, 2017, p. 96) Apesar dele discordar de Heidegger acerca do conteúdo filosófico deste paradigma, o pensamento dos três autores (Heidegger - Jünger - Agamben) pode ser cotizado desde já a partir

vontade do indivíduo, que se afirma, por exemplo, transexual). O predomínio deste discurso voluntarista e a sua associação com a questão da dignidade humana tem sido objeto de constante debate na comunidade jurídica brasileira, e o professor Barroso tem participado enquanto acadêmico e Ministro do Supremo Tribunal Federal, tendo muitas vezes suas manifestações sido em prol de um juízo voluntarista acerca do significado da existência humana, o que está de perfeito acordo com o afirmado no texto citado. Carl Schmitt, no final de sua Teologia Política II, é quem dá o tom da crítica: Eripuit fulmen caelo, nova fulmina mittit/ Eripuit caelum deo, nova spatia struit./ Homo homini res mutanda/ Nemo contra hominem nisi homo ipse (Roubou do céu o raio e laçou novos raios/ Roubou o céu de deus e construiu novos espaços/ O homem é para outro homem algo a ser mudado/ Ninguém é contra o homem, exceto ele mesmo). Impossível também não ser recordada a obra de Mary Shelley que, intrinsecamente vinculada à estrofe schmittiana por seu subtítulo, qual seja, "O Novo Prometeu", é um cautionary tale acerca dos riscos da manipulação pelo homem daquilo que durante a maior parte de sua história lhe foi vedado mesmo entender, que seja, o mistério de sua estrutura genética - cuja conhecimento outrora pertencia, e o professor Barroso acidentalmente o relembra, tão somente a Divindade. Este alarme em torno da utilização por Barroso da expressão "deuses" pode parecer exagerado, mas recente prova para ingresso na carreira de defensor público do Estado do Rio de Janeiro exemplifica a normalização deste discurso de manipulação feno-genotípica. Na prova escrita discursiva de caráter geral do XXIII Concurso, realizada em 2010, a 12a Questão relatava e perguntava: "Um indivíduo hipossuficiente, interessado em participar da prática de modificação extrema do corpo (body modification extreme), decidiu se submeter a cirurgias modificadoras, a fim de deixar seu rosto com a aparência de um lagarto. Para tanto, pretende enxertar pequenas e médias bolas de silicone acima das sobrancelhas e nas bochechas, e, após essas operações, tatuar integralmente sua face de forma a parecer a pele do anfibio. Frustrado, após passar por alguns hospitais públicos, onde houve recusa na realização das mencionadas operações, o indivíduo decidiu procurar a Defensoria Pública para assistilo em sua pretensão. Pergunta-se: você, como Defensor Público, entende ser viável a pretensão? Fundamente a resposta. (7,0 pontos)” Recebeu nota máxima quem respondeu que o defensor público deveria ajuizar a ação, com base no princípio da busca da felicidade, que, no Brasil, em razão da inexistência de previsão explícita constitucional de sua incorporação ao ordenamento, é relacionado ao princípio da dignidade humana.

45 "Enquanto para o homem antigo o instrumento acaba anulado no ergon que ele produz, assim como o trabalho desaparecia em seu resultado, agora a operação do instrumento cinde-se em um fim próprio e em uma finalidade extrínseca, fazendo emergir dessa maneira a esfera de uma instrumentalidade que pode ser dirigida para qualquer fim. O espaço da técnica abre-se, nesse ponto, como a dimensão de uma medialidade e uma disponibilidade propriamente ilimitadas, porque, mesmo mantendo-se vinculado à própria 
de uma perspectiva do que representa o alçar da técnica a mecanismo hermenêutico durante a modernidade: a funcionalização do homem enquanto parte da sociedade. ${ }^{46} 47$

Jünger, em outra obra, Über die Linie, que trata acerca do niilismo, volta ao debate com Heidegger, mas a partir de outra perspectiva. A conclusão a que chega é que o trabalho como arcanum do mundo levou a um estado de funcionalização absoluta, de niilismo universal. ${ }^{48}$ Este passo filosófico que Jünger dá só é importante se

ação, o instrumento tornou-se autônomo em relação a ela e pôde-se referir a qualquer finalidade extrínseca." in AGAMBEN, Giorgio. O Uso dos Corpos. São Paulo: Boitempo Editorial, 2017, p. 96.

${ }^{46}$ Agamben discorda, e vê no desenvolvimento da técnica moderna não o estabelecimento da absoluta zona de indeferenciação entre trabalhador e máquina que Jünger verifica e que leva à funcionalização absoluta do homem e a transformação do próprio homem em máquina, mas a possibilidade da máquina agir para libertar o homem da necessidade (como o escravo outrora havia feito), feito que, segundo os parâmetros da Antiguidade clássica, tornaria o homem livre e, portanto, habilitado a atuar politicamente. AGAMBEN, Giorgio. O Uso dos Corpos. São Paulo: Boitempo Editorial, 2017, p. 101. Surge no entanto, uma possibilidade de dúvida no seu pensar, quando afirma que "é preciso restituir ao escravo o significado decisivo que lhe cabe no processo da antropogênese. O escravo é, por um lado, um animal humano (ou um homem-animal) e, por outro, e na mesma medida, um instrumento vivo (ou um homem-instrumento). Assim, o escravo constitui, na história da antropogênese, um limiar duplo: nela, a vida animal transpassa para a humana, assim como o vivo (homem) transpassa para o inorgânico (instrumento), e vice-versa. A invenção da escravidão como instituto jurídico permitiu a captura do ser vivo e do uso do corpo nos sistemas produtivos, bloqueando temporariamente o desenvolvimento do instrumento tecnológico; sua abolição na modernidade libertou a possibilidade da técnica, ou seja, do instrumento vivo. Ao mesmo tempo, enquanto sua relação com a natureza não é mais mediada por outro homem, mas por um dispositivo, o homem afastou-se do animal e do orgânico para se aproximar do instrumento e do inorgânico até quase identificar-se com ele (o homem-máquina). Por isso - enquanto havia perdido, com o uso dos corpos, a relação imediata com a própria animalidade -, o homem moderno não pôde apropriar-se realmente da libertação com relação ao trabalho que as máquinas deveriam ter-lhe proporcionado. E, se a hipótese de um nexo constitutivo entre escravidão e técnica for correta, não causa espanto que a hipertrofia dos dispositivos tecnológicos tenha produzido uma nova e inaudita forma de escravidão." (p. 102) O escravo, com suas características, só tem zoēs, ou seja, vida nua, privada, destituída de sentido político. Há uma indeterminação desta escravidão em relação aos instrumentos mais altos do Estado (oficiais do Estado) por causa da lógica do múnus. Mas o resto da população é, em regra, reduzida à animalidade própria da escravidão pela tecnicização da vida (e do trabalho - e é importante pensar quanto a noção protestante de Beruf, estudada mais a frente, auxiliou neste processo de esvaziamento teleológico da vida humana).

${ }^{47}$ A causa instrumental, que é a sua transformação em engrenagem maquinal, "não é, portanto, apenas uma especificação da causa eficiente; ela é, igualmente e na mesma medida, uma transformação da causa final e da função própria de certo ente - o instrumento - que acaba sendo constitutiva e necessariamente subsumida em uma causa final externa, a qual, por sua vez, para se realizar, depende também necessariamente delas. $\mathrm{O}$ aparecimento do dispositivo da causa instrumental (que define, conforme observamos, a própria natureza de toda ação 'dispositiva') coincide, nesse sentido, com uma transformação radical no modo de conceber o uso. Esse uso já não é uma relação de dupla e recíproca afeição, em que sujeito e objeto se indeterminam, mas uma relação hierárquica entre duas causas, definida não mais pelo uso, mas pela instrumentalidade. A causa instrumental (na qual o instrumento - que no mundo antigo parece constituir uma unidade com a mão de quem dela se serve - alcança sua plena autonomia) é o primeiro aparecimento na esfera da ação humana dos conceitos de utilidade e instrumentalidade que determinarão o modo pelo qual o homem moderno entenderá seu fazer na modernidade." in AGAMBEN, Giorgio. O Uso dos Corpos. São Paulo: Boitempo Editorial, 2017,p. 97.

48 "Em Der Arbeiter, o Estado de trabalho parece, na sua descrição, coincidir com o Estado totalitário que, nos seus pressupostos, tinha sucumbido na Segunda Guerra Mundial. Para o Jünger de Über die Linie, pelo contrário, a mobilização total que está subjacente ao Estado de trabalho não se pode esgotar na sua configuração totalitária, constituindo um processo que se estende para além da derrota militar da violência explícita e do terror dos Estados totalitários. Nesta perspectiva, é certo que, em 1950, algumas das mais extremas configurações do Estado totalitário, em particular o nacionalsocialismo alemão, tinham desaparecido. É certo que a violência de um poder total do Estado, exercido internamente sobre um singular reduzido a nada, se encontrava, em 1950, militarmente derrotada. Mas a essência desta mesma violência, o niilismo, como terror (Schrecken) e a angústia (Angst) por ele necessariamente gerados, num terror e numa angústia que se tornam cada vez mais indeterminados, poderia ainda aumentar sob os escombros da sua própria determinação política e institucional. Ao contrário do que se tinha passado com a emergência dos Estados totalitários, em que a violência tirânica tinha dado lugar a uma catástrofe explícita e manifesta, a mobilização pelo Estado de trabalho, o niilismo não desaparece, mas adquire uma outra configuração. É para a sua descrição que Jünger se apropria, em 1950, 
reconhecerse em seu objeto a ausência de valores - e, consequentemente, de valores positivos. Instaura-se, neste caso, um estado de funcionalização absoluto que prescinde inclusive do motor que o justificava no Estado totalitário, a ideia de uma comunidade. É um estado (psíquico) unicamente de esvaziamento de significado de uma esfera de relevante impacto público na modernidade, qual seja, a do trabalho (bem como de todas as outras esferas, mas esta é particularmente impactante porque fôra foco do Der Arbeiter). A ideia do autor não remetia, a priori, à representação política, mas ele reconhecia, em seu Der Arbeiter, que, no mundo de matérias titânicas, a manifestação política deveria se dar através de um sistema de representação que se assemelha mais ao modelo feudal/medieval (ele usa a expressão feudal) que ao modelo da democracia representativa liberal. O voto seria só um número e a massa deveria, mais do que votar, se identificar com seu Führer, seu líder. Passada a guerra, apesar de já ter se distanciado durante os conflitos de forma muito pública do nazismo, tendo flertado com o círculo do poeta Stefan George, donde saiu o Conde von Stauffenberg, responsável pelo atentado contra a vida de Hitler que ficou conhecido como Operação Valquíria, Jünger reformula suas ideias, inclusive seu comunitarismo. E o trabalho, ao qual atribuía a representação política por excelência da massa, não só perde a relevância como ganha uma relevância negativa - é um dos redutos do niilismo, do vazio.

É, na verdade, a ideia de Aristóteles aplicada aos tempos modernos. Se o homem trabalha, não é livre; se não é livre, não pode ser político; se não é livre e não é político, sua existência é suprimida (a mesma conclusão de Heidegger, com o mesmo instrumento explicativo: o niilismo, a falta de enraizamento). Como resolver esta questão? Jünger desenvolve algumas propostas nos anos restantes de sua carreira. A comunidade que ele busca não é mais uma comunidade física, necessariamente. Nesta nova comunidade o trabalho não tem que significar nada. O niilismo, afinal:

encontra na ordem um substrato poderoso - aliás, ele almeja e é fruto de uma ordem abstrata, o Estado aperfeiçoado, com seus funcionários e peças azeitadas, precisamente quando as

\footnotetext{
dos próprios termos de Nietzsche. Segundo Nietzsche, o niilismo consistia, na sua essência, numa desvalorização dos valores supremos e, com ela, numa perda pelo homem da possibilidade de atribuir à vida uma meta e um sentido: 'O que significa niilismo? Que os valores supremos se desvalorizam. Falta a meta. Falta a resposta ao 'para quê?". Uma tal perda só se tornaria sentida e dolorosa, só se tornaria patológica, num estado intermédio (Zwischenzustand), onde o homem sentiria a perda do 'para quê?' como uma desvalorização e uma ausência. Para além desse estado intermédio, tornar-se-ia possível vislumbrar um estado (Zustand) em que o niilismo se tornasse normal e a sua presença deixasse de ser sentida patologicamente. Um tal niilismo enquanto 'estado normal' surge, segundo Nietzsche, como essencialmente 'ambíguo'. E a razão dessa ambiguidade é clara. Como escreve Nietzsche: 'O niilismo como fenómeno normal pode ser um sintoma de força crescente ou de fraqueza crescente'. E a força e a fraqueza crescentes no niilismo, enquanto 'estado normal', são facilmente visíveis: 'O seu maximum de força relativa, ele alcançao enquanto força violenta de destruição: enquanto nilismo activo. $O$ seu oposto seria o niilismo cansado, que já não ataca: a sua forma mais famosa é o budismo: enquanto niilismo passivo, enquanto sinal de fraqueza: a força do espírito pode estar cansada, esgotada, de tal modo que as metas e valores vigentes até agora são inadequados e já não encontram nenhuma fé.. Em Über die Linie, Jünger insiste na caracterização por Nietzsche de um 'estado normal' do niilismo. E esta insistência na possibilidade de o niilismo constituir um 'estado normal' tem justamente, para Jünger, um significado preciso: o reconhecimento de que o nilismo é essencialmente ambíguo na sua manifestação, ou seja, o reconhecimento de que há vários modos de o niilismo se configurar como fenómeno e de que, consequentemente, não é imprescindível a ocorrência patente da tragédia, da guerra e da destruição para que ele esteja presente." In FRANCO DE SÁ, Alexandre. A Política sobre a Linha: Martin Heidegger, Ernst Jünger e a Confrontação sobre a era do Niilismo. Covilhã: LusoSofia Press, 2008, p. 33.
} 
ideiasforça que o dirigiam se perdem ou entram em decrepitude, fazendo subsistir apenas uma sombra de existência no proscênio. ${ }^{49}$

Jünger, através de seus personagens, responde, afirmando a supremacia do espírito sobre a matéria, ainda que não realize uma operação de diferenciação absoluta entre os dois. Primeiro como os herbalistas, que reconhecem na vita contemplativa uma forma melhor de se viver, e fogem da destruição das condições de manutenção desta forma de vida. Depois, como Venator, que se define enquanto personagem pela sua relação com a autoridade, de emancipação. Ele está para além da possibilidade de domínio, apesar de existir dentro de um conceito de domínio.

Os herbalistas representam o tipo Rebelde, aquele que vai para a floresta (Waldgänger). Já Martin Venator, que trabalha durante a noite para o Condor, representa o Anarca.

Para Jünger, a resistência se faz na resiliência no real e na liberdade absoluta mental, elementos que configuram o Anarca enquanto tipo, assim como o Soldado do Front, o Trabalhador e o Rebelde. O Anarca é quem consegue se opor a esta funcionalização da vida que é uma funcionalização dos homens em si, que se faz, como se verá, pela palavra de comando, internalizada enquanto construtora de sentido, como dever, como se verá mais a frente. O Anarca é, enfim, a encarnação na contemporaneidade, do homem virtuoso, da Antiguidade.

O Anarca não nega a autoridade, não nega a funcionalização - nega a associação do seu espírito a sua expressão social, trabalho, política. O Anarca é o homem que exerce o trabalho, mas não é seu trabalho. Ele está no centro da roda das mudanças do mundo e, por isso mesmo, não se move. A solução que Jünger apresenta com o Anarca é a solução que Evola apresenta com seu Cavalcare la tigre, que foi partilhada por inúmeros tradicionalistas e reacionários, em especial na Itália da década de setenta: não fazer nada. A guerra exterior contra a modernidade já havia sido perdida. Deveria-se lutar pela preservação do interior, pela não contaminação do eu com a moléstia da modernidade - representada maximamente pela funcionalização.

Agamben opta por um caminho parecido, o caminho da inoperatividade, ${ }^{50}$ no último capítulo de sua série Homo Sacer, intitulado O Uso dos Corpos. Mas esta sua inoperatividade segue uma trajetória

\footnotetext{
${ }^{49}$ Continuando: "Nesse caso, o imperativo é que tudo funcione, mas justamente o 'tudo funcionando' é que denota a morte. Pensemos isso em uma escala maior: pode-se imaginar partidos proliferando, mas espelhando o Estado a que se opõem, de modo que temos o exército, os cartéis, trustes, caixas de seguridade social, sindicatos, tudo funcionando azeitadamente, recrutando com facilidade juizes, generais, professores. Como diz Jünger, a virtude do funcionário é funcionar." In PELBART, Peter Pál. O Avesso do Niilismo: Cartografias do Esgotamento. São Paulo: n-1 Edições, 2013, p. 138.

${ }^{50}$ Agamben lembra que "Bataille propõe a figura de uma soberania inteiramente consumida no instante (a única inocência possível: aquele do instante) que coincide com 'as formas pelas quais o homem se entrega a si mesmo:... risada, erotismo, luta, luxúria/luxo.' O tema da désœuvrement - inoperatividade como figura da plenitude do homem no final da história - que aparece pela primeira vez na revisão de Queneau de Kojève, foi tomada por Blanchot e por Nancy, que a coloca no centro da sua obra The Inoperative Community. Tudo depende do que se quer dizer por 'inoperatividade'. Não pode ser nem a simples ausência de trabalho nem (como em Bataille) uma forma soberana e inútil de negatividade. A única maneira coerente de entender a inoperatividade é pensar nela como um modo genérico de potencialidade que não está esgotado (como ação individual ou ação coletiva entendida como a soma de ações individuais) em um transitus de potenciala ad actum." Ou seja, uma potência não exaurida, de cujo maior exemplo é o Bartleby de Melville e que será recuperado mais a frente. Trechos In AGAMBEN, Giorgio. Homo Sacer: Sovereign Power and
} 
profundamente diferente da de Jünger, ou mesmo da de Evola. É uma inoperatividade da entrega daquilo que é amado, do corpo, como o próprio título diz, ao uso - desconstruir a biopolítica da qual o nazismo foi uma das expressões máximas através do mergulho na domesticidade da vida não política, e não tentar fazer isso político. ${ }^{51}$

Esta evasão do espaço público para celebrar na domesticidade o comum pode agir de duas formas: a ruim, com a politização da vida nua - do espaço doméstico - ou através da domesticização do político. Em ambos os casos, o que se busca é o combate do esvaziamento do significado do comum, um através da extensão infinita do espaço público (comum), outro através da sua anulação na domesticidade - o corpo como paradigma do que é mais absolutamente doméstico. O corpo é, portanto, na obra de Agamben, o grande eixo da discussão do político. $^{52}$

Sua ideia, portanto, pode dar errado, é o que diz - mas pode dar certo também, a partir unicamente da dimensão ética da atribuição de significado ao comum - pode-se ser Dolmancé ou um dos senhores de Silling. Qual é a elaboração desta ética?

Contra esta tentativa de apropriar-se, por meio do direito ou da força, do inapropriável afim de constituílo arcanum da soberania, é preciso lembrar que a intimidade só pode conservar o seu significado político à custa de continuar inapropriável.

Comum nunca é uma propriedade, somente o inapropriável. O compartilhamento desse inapropriável é o amor, o 'uso da coisa amada' de que o universo sadiano constitui a mais séria e instrutiva paródia. ${ }^{53}$

Esta solução se assemelha a de Jünger (HEIDEGGER e JÜNGER, 1989, p. 95), que vai para aspectos da

\begin{abstract}
Bare Life. Stanford: Stanford University Press, p. 40.
${ }^{51}$ Em certo momento desta obra, ele diz "[C] ompreende-se, então, que, numa sociedade formada por indivíduos, a transformação do uso de si e da relação com o inapropriável em cuidadosa posse tem, na realidade, um significado político que é tanto mais decisivo quanto mais continua obstinadamente escondido. É na obra de Sade - ou seja, justamente no momento em que cada um dos seres vivos se torna portador da nova soberania nacional - que tal significado político aparece com vigor. No manifesto 'Français encore un effort si vous voulez être républicains' [Franceses, façam um esforço se desejam ser republicanos], que o libertino Dolmancé lê em Philosophie dans le boudoir, são as maisons que se tornam o lugar político por excelência, onde cada cidadão tem o direito de convocar todos os outros para usar livremente seu corpo. A intimidade torna-se aqui o que está em jogo na política, enquanto o boudoir substitui integralmente a cité. Se o sujeito soberano é, acima de tudo, soberano sobre o próprio corpo, se a intimidade - ou seja, o uso de si mesmo como inapropriável - se torna a substância biopolítica fundamental, então se compreenderá que em Sade ela possa apresentar-se como objeto do primeiro e inconfessado direito do cidadão: cada indivíduo tem direito de compartilhar a seu bel-prazer o inapropriável do outro. Comum é, acima de tudo, o uso dos corpos." in AGAMBEN, Giorgio. O Uso dos Corpos. São Paulo: Boitempo Editorial, 2017, p. 116.

52 Assim, em outras obras, mas nessa também, ele lembra que "[A] quilo que no pamphlet de Dolmancé era um contrato jurídico constitucional, fundado na reciprocidade republicana, se apresenta, por sua vez, em 120 dias de Sodoma como puro objeto do domínio e da violência incondicionada (certamente não é por acaso que a perda de qualquer controle sobre a própria intimidade era, de acordo com os testemunhos dos deportados, parte integrante das atrocidades do Lager). O pacto criminoso que rege o castelo de Silling, em que os quatro perversos poderosos se fecham com suas quarenta vítimas, estabelece o controle absoluto dos senhores sobre a intimidade de seus escravos - até mesmo suas funções fisiológicas são minuciosamente reguladas - o uso integral e ilimitado de seus corpos. É assim que a relação com o inapropriável, que constitui a substância biopolítica de cada indivíduo, acaba violentamente apropriada por quem se constitui, dessa maneira, senhor da intimidade, senhor do livre uso do próprio que, nas palavras de Hölderlin, se apresentava como 'a coisa mais difícil'." in AGAMBEN, Giorgio. O Uso dos Corpos. São Paulo: Boitempo Editorial, 2017, p. 116-7.
\end{abstract}


vida doméstica, como o sexo, o amor e a amizade, para buscar a criação de um significado comum que sirva para o combate ao niilismo. Seu pensamento, à época, não era ainda o do Anarca, mas o do Rebelde, então ele referencia constantemente o Wildnis, para onde vai o Waldgänger, o Rebelde. Esta parece ser a dimensão na qual ele se aproxima de um conceito de comum geográfico, ou seja, comum que não é mero significado ético-metafísico, mas um comum econômico. A criação de outra realidade ainda é, neste momento, para ele, associada - ainda que menos nesta obra do que em Der Waldgang, publicada no mesmo ano - ao exílio e ao rompimento com esta realidade.

Nesta referência constante ao Wildnis e ao Waldgang que Jünger se distancia de Agamben e se aproxima mais do franciscanismo original, que será tratado mais à frente. Porque a inoperatividade (de Agamben), a imobilidade (do Anarca) e o exílio (dos herbalistas e do rebelde) não necessariamente têm a mesma dinâmica.

A ideia de Heidegger acerca do conceito de comunidade e do significado existencial da comunidade para o homem é boa, e pode ser uma das facetas do argumento nesta monografia sustentado. É sua vinculação com o aspecto técnico da modernidade que parece inadequada. A expansão irrestrita da noção de dever remete a esta funcionalização do homem - consequência da ontologia da efetualidade cujo surgimento se está a explorar presente nas obras de Jünger da década de 30 , mas no que ela toca ao conceito de liderança, como feito por Schmitt ou por Pohlenz, a fusão da zoēsà bios no líder, o desenvolvimento parece correto. Em relação aos demais cidadãos da comunidade, antes de imaginá-los enquanto tipos ou funções dessubjetificadas, a visão de Heidegger poderia remeter mais adequadamente ao conceito de forma-de-vida. Logo, dois são os desvios possíveis e que devem ser combatidos: a anulação do sujeito em relação à função através da técnica e a submissão de toda a hermenêutica da ordem à autoridade.

Estes autores retratavam o que viam e viam o que parecia ser o renascimento nacional através de dois aspectos: o conceito de comunidade (ou seja, a estruturação política do conceito do político schmittiano: aqui os amigos, lá os inimigos) e a ascensão da técnica (técnica que envolve o homem em três aspectos: funcionalização deste em relação a um fim comum; melhoramento do homem em seu aspecto biológico que reflete necessariamente em seu aspecto moral, ético e político; manipulação das forças titânicas - matérias do mundo para a criação de um novo mundo natural segundo a vontade do homem). Eles sabiam que realizações políticas desta espécie já haviam ocorrido antes na história, mas era para o futuro que olhavam. Antes parece que deveriam ter olhado para o passado e ver que, se de fato muitos de suas assunções acerca da necessidade de uma comunidade que fosse preservada contra a sociedade para a maior realização existencial do homem estavam corretas, e os elementos essenciais esquadrinhados por eles também o estavam, não era na técnica que se realizaria a ética. Se a técnica efetivamente pode servir para a manipulação do comportamento (através das leis e da

\footnotetext{
${ }^{53}$ As duas últimas citações vieram de AGAMBEN, Giorgio. O Uso dos Corpos. São Paulo: Boitempo Editorial, 2017, p. 117.
} vol.11, no. 02, Rio de Janeiro, 2018. pp. 1172- 1267 
economia das necessidades da vida nua), a técnica esvazia a vontade e, consequentemente, leva à morte da comunidade. O homem já não vê mais porque preservar uma determinada ordem e já está existencialmente morto. A partir daí, e só a partir daí, e isso mesmo em caso de regimes totalitários brutais, é que o Lager se torna efetivamente o campo máximo da política. É só então que o niilismo impera.

Em síntese do capítulo segundo da Opus Dei, que vem ao fim do capítulo, Agamben traz um resumo da tese principal que importa ao presente trabalho. ${ }^{54}$ Interessante verificar, neste sentido, para aproximar, desde já, a discussão de questões práticas importantes, a distância já existente entre o significado do exercício do poder pelo magistrado romano, ou ainda, pelo magistrado durante toda a Alta Idade Média e durante o Ancien régime, e o dado ao magistrado americano desde meados do século XIX.

Weber nos relata (WEBER, 1999, p. 92) que, "para o parecer popular do americano" a ocupação do juiz é um business, como a de um comerciante qualquer, onde este detém o monopólio do fornecimento de uma decision, através da qual a parte" pode forçar terceiros a determinados atos ou, ao contrário, proteger-se contra a exigência, por parte destes, de realizar certos atos." Aqui há claramente a noção de officium sendo posta socialmente em prática, identificada através de uma percepção social. Quem exara a decisão não importa para o pleiteante, mas tão somente seu conteúdo, regulação dada pelo Estado ao objeto litigioso (quanto a posição dos detentores desta espécie de ofício no Ancien régime, já foi tratado aqui em cima, quando se referiu a questão da leitourgia). ${ }^{55}$

Da mesma forma, se analisar-se o Código de Processo Civil Brasileiro, e tantos outros Códigos relativos ao procedimento processual, das mais diversas nacionalidades, no tocante às razões de anulação da decisão, ou seja, reconhecimento de que a tutela jurisdicional não foi feita nos moldes esperados pelo sistema judicial, contemporaneamente, verificar-se-á que as causas de anulação estão vinculadas ora à probidade do magistrado no momento de julgamento da causa, ou seja, à violação objetiva da imparcialidade por parte do magistrado verificada pelo favorecimento deliberado de uma parte e causalmente relacionado a uma ação da parte que dê justificativa a esta violação, ora a falsidade dos elementos trazidos pela parte como prova de seu direito. Só é

\footnotetext{
54 “1) Na liturgia está em questão um novo paradigma ontológico-prático, a efetualidade, no qual ser e agir entram em um limiar de indecidibilidade. Se, nas palavras de Foucault, Platão ensinava ao político não o que devia fazer, mas o que devia ser para poder, eventualmente, agir bem, trata-se agora de mostrar como se deve agir para poder ser - ou melhor, atingir um ponto de indiferença, no qual o sacerdote é aquilo que deve fazer e deve fazer aquilo que é. A subordinação do agir ao ser, que define a filosofia clássica, perde assim seu significado. [... 4) Nessa dimensão, causa e efeito subsistem, mas, ao mesmo tempo, indeterminam-se: por um lado, o agente age somente enquanto é, por sua vez, efeito (enquanto, como instrumento, é movido por um agente principal); por outro, o efeito se autonomiza de sua causa (que lhe é só causa instrumental e não eficiente nem final). 5) Consequentemente a ação sacramental é cindida em duas: uma ação manifesta (opus operans ou operantis) que parece agir, mas que em realidade não faz senão oferecer o instrumento e a "vez" a um agente oculto, a quem compete toda a eficácia da operação. Mas é justamente graças a essa separação da ação (reduzida a causa instrumental) de sua eficácia que a operação sacramental pode alcançar invariavelmente sua efetualidade ex opere operato." in AGAMBEN, Giorgio. Opus Dei: Arqueologia do Ofício. São Paulo: Boitempo Editorial, 2013, p. 71 .
} 
possível, acerca da matéria da decisão em si, a reforma, onde outros magistrados avaliam a substância da decisão proferida por um magistrado, sem limites objetivos não vinculados a qualquer procedimento de deliberação por magistrados que demarquem a atuação dos magistrados que estão envolvidos no procedimento judicial.

Igualmente, ao verificar as razões pelas quais pode um magistrado ser punido, verificar-se-á que nenhuma delas tem vínculo direto com o conteúdo das decisões, mas sim com algumas das circunstâncias que possam justificar porque uma decisão foi de certa forma. A partir destes dados só se pode extrair a conclusão de que o magistrado não tem verdadeira responsabilidade pelas ações vinculadas ao exercício de sua função, ou seja, ele não é responsável pela interpretação que dá ao Direito, quaisquer que sejam os meios através dos quais ele se expresse (leis, jurisprudência, doutrina). Ele só é por elas responsável se sua capacidade para decidir, no caso, de forma especificamente imparcial, foi afetada.

É fácil associar esta situação de irresponsabilidade do magistrado com a do padre, que não é responsável pela consagração da hóstia. A decisão judicial pode ser absolutamente teratológica, mas ela em si é o que importa, mesmo que seu conteúdo não tenha forma definitiva até o trânsito em julgado. E assim o é porque, como a consagração da hóstia é opus operatum de Jesus Cristo, a exaração da decisão judicial é opus operatum do EstadoLei (Ordenamento), motivo pelo qual, inclusive, ele, e não o magistrado, é responsável civilmente pela indenização diante das consequências de uma decisão errada. Como o padre é instrumento de Deus enquanto membro da Igreja-instituição, o juiz é instrumento do Estado.

O próprio Tomás de Aquino, por sua vez, se utiliza da expressão “instrumento animado" para se referir ao padre, segundo Agamben. $\mathrm{O}$ autor italiano contemporâneo verifica que a origem deste termo se encontra na Política de Aristóteles, na qual é utilizado para definir a natureza do escravo. Ele mesmo explica que o termo minister, que é usado para padres na obra de Tomás, bem como para diversos oficiais do Estado, significa servo, e que este sentido é conhecido por Tomás. ${ }^{56} \mathrm{O}$ mesmo ocorre na organização do Estado e, especificamente, no caso do Poder Judiciário. O escravo, segundo Agamben, constitui "o primeiro aparecimento de uma pura instrumentalidade, ou seja, de um ser que, ao viver segundo o próprio fim, é, justamente por ela e na mesma medida, usado para um fim de outrem." (AGAMBEN, 2017, p. 98). ${ }^{57}$

\footnotetext{
${ }^{55}$ Remete-se às notas 16 e 18 para a discussão acerca da relação entre as teorias do officium, do munus e da leitourgia e o alvorecer de uma nova ontologia da efetualidade.

56 "Portanto, a assimilação do celebrante a um escravo - que não tem personalidade jurídica e cujos atos são imputados à 'pessoa' do senhor - é perfeitamente consciente, e é em virtude dessa consciência que Tomás pode escrever que 'o ministro no sacramento age in persona de toda a Igreja, da qual é ministro' (q. 62, art. 8). Isso significa que, pelo paradigma do 'instrumento animado', o sacerdócio sacramental está geneologicamente, não só terminologicamente, vinculado à escravidão." in AGAMBEN, Giorgio. O Uso dos Corpos. São Paulo: Boitempo Editorial, 2017, p. 98.

${ }^{57}$ Da mesma forma, ao tratar do sacramento, opus do sacerdote, afirma que "eles são uma espécie de profecia do maquinismo, que só ocorrerá cinco séculos depois. Assim como a máquina, ao materializar o sonho do instrumento animado, funciona sozinha e quem a manobra, na realidade, nada mais faz do que obedecer às possibilidades de comando prescritas pela própria máquina, também o sacramento produz seu efeito ex opere operato, e o celebrante - de quem Tomás diz que 'enquanto é movido pelo
} 
Por mais que se tente atualmente gerar um senso de responsabilidade no magistrado pelas suas decisões, este senso, enquanto o sistema for como é, só poderá ser um senso privado e, portanto, sem consequências políticas. O poder judiciário brasileiro é, em razão deste sistema, um poder que gera impacto político com suas decisões, mas não é um poder político. É, na verdade, um poder composto de servidores públicos irresponsáveis pelas suas decisões. Em alguns Estados americanos, onde a magistratura é eleita, o magistrado é membro de um poder político, porque ele é responsável pelas suas decisões, responsabilidade que é avaliada através das eleições. Se o magistrado atuou bem, segundo a opinião da comunidade, ele é reeleito, observadas as limitações para manter-se a legalidade. Se ele atuou mal, não é reeleito. Mas, dentro de uma democracia, ${ }^{58}$ todo representante de um poder político é sempre um servidor público.

A incongruência no sistema nacional é que o magistrado não tem nenhum meio de responsabilização perante a pólis e exerce sobre ela poder, e mais, não tem sua atuação averiguada através de um padrão de legitimação da atuação da autoridade, ou seja, ao não ter suas decisões anuladas ou reformadas em razão de sua sentença, ainda que se oponham ao Direito enquanto percepção da pólis. Sistemas que assim se estruturam não são verdadeiramente democráticos e tendem a, mais cedo ou mais tarde, gerar situações nas quais o único caminho possível é a destruição do sistema. ${ }^{59}$

A verificação desta afirmação é fácil de ser feita se comparados o sistema do magistrado irresponsável, brasileiro, e o sistema absolutista da França. Em um sistema, o primeiro, o povo é visto como soberano e os poderes políticos a sua vontade se submetem, por diversos meios. Assim, a vontade do povo, verificada por meios formais e informais, é o parâmetro da atuação dos poderes políticos. No absolutismo monárquico, o poder pode ora ser legitimado com base na vontade divina ora com base na vontade do povo. ${ }^{60}$

agente principal, não é somente causa, mas de algum modo também efeito' (q. 62, art. 1) - nada mais faz do que executar, mais ou menos mecanicamente, a vontade do agente principal. A analogia pode ser continuada: se o advento da máquina, conforme já havia sinalizado Marx, teve como consequência a degradação do trabalho do artesão, que, ao perder sua habilidade tradicional, se transforma em instrumento da máquina, isso corresponde pontualmente à doutrina do opus operatum, que, ao transformar o celebrante em instrumento animado, o separa de fato do empenho pessoal e da responsabilidade moral, que já não são necessários para a eficácia da práxis sacramental e ficam confinados em sua interioridade." Esta reflexão se aplica perfeitamente aos atos da magistratura e sua relação com os magistrados que os exaram. Trecho in AGAMBEN, Giorgio. O Uso dos Corpos. São Paulo: Boitempo Editorial, 2017, p. 99.

${ }^{58} \mathrm{~A}$ discussão aqui acerca do que é democrático é uma discussão que será levada em um grau muito primitivo, adotando-se a definição básica de Weber de uma sociedade democrática, que em seu Economia e Sociedade, afirma: "Chama-se 'democrática' por duas razões que não coincidem necessariamente, a saber: 1) porque se baseia no pressuposto da qualificação igual, em princípio, de todos para a direção dos assuntos comuns, e 2) porque minimiza a extensão do poder de mando." in WEBER, Max. Economia e Sociedade: Fundamentos da Sociologia Compreensiva, Volume II. Brasília: Editora UNB, 1999, p. 193.

${ }^{59}$ Agamben trabalha outra faceta desta reunião que foi tratada aqui a partir das noções de irresponsabilidade e de poder decisório sobre a vida política (ele vai falar de junção de auctoritas e potestas), mas, em ambas as análises, a conclusão é a mesma, qual seja, de que esta reunião é desastrosa. Como ela será referida mais a frente, não será enfrentada aqui.

${ }^{60}$ É importante atentar aqui para a sutil diferença entre o povo como base do poder, ou seja, justificação para o exercício do poder e esta justificação pode estar vinculada a um argumento histórico (o rei é absoluto e é assim porque assim é o costume, mas a base de seu poder não é Deus ou um deus - a autoridade pertencia originalmente ao povo e, por algum motivo, foi parar nas mãos do rei) ou de excelência (o sistema da monarquia absoluta é o melhor sistema para se atingir o bem comum determinado pelo povo ) - 
$\mathrm{Na}$ França, ora uma justificativa foi invocada, ora a outra, como se verá. Apesar de tantas revoltas populares que a monarquia francesa enfrentou através dos séculos, em nenhuma das muitas vezes que ela capitulou ela perdeu seu poder, quiçá foi destruída na pessoa física de seu rei. Só uma, justo quando a revolução afirmou politicamente a soberania do povo enquanto poder político. Nas revoltas anteriores, o rei-pessoa física poderia ser perseguido, deposto, até executado, mas o rei-pessoa política permanecia porquanto era só na pessoa dele que se reconhecia o exercício do poder político legitimado, porque ele havia sido, qualquer que fosse a percepção social de como este fato se deu, eleito por Deus para o desempenho do cargo. O exercício deste cargo tinha mais exemplos a serem imitados do que propriamente limites e obrigações, ou seja, o rei deveria ser de certa forma, tanto que muitas das revoltas se davam em razão da inadequação dos detentores deste cargo (bem como em relação aos detentores de quaisquer cargos desta natureza) aos padrões de comportamento exemplares, mas, retificada a inadequação, o poder político se reestabilizava.

O Brasil é um país no qual a reflexão política por parte de seus cidadãos não chegou ainda à conclusão comum de que o paradigma mínimo de uma democracia é que quem diz o que é legítimo é o povo. Assim, é possível a perpetuação de uma classe política que enfrenta constantes processos questionadores da probidade de seu exercício do cargo, porque, depois de décadas de construções políticas autoritárias, nos ambientes privados e públicos, ainda se crê que certas pessoas detém certos poderes legitimamente, independentemente da doutrinação democrática fundada em instituições como a rotatividade dos cargos e eleições, além de outros elementos próprios da imaginação política do brasileiro que não interessam a esta pesquisa.

Da mesma forma, a autoridade do juiz também é intocada pela reflexão popular por diversas razões. Mas, diferente do caso dos cargos eletivos, não há válvula de escape para o questionamento levantado a partir de uma decisão injusta. A irresignação popular, nestes casos, tende a adquirir formas de expressão violentas. Nas recentes manifestações de indignação política já foram vistos cartazes onde estava escrito "Fora STF”, muito provavelmente em razão de suspeitas de corrupção, motivo inicial das manifestações, de certos membros de seu corpo, vinculados a partido fortemente hostilizado nestas manifestações. Mas o STF tomou decisões políticas recentemente que ainda parecem contar com pouco suporte da maior parte da população que, no entanto, acredita-se que estas decisões são de responsabilidade do Parlamento, e busca através do Parlamento combate-las. Os protestos voltados contra o STF, no entanto, já apresentam certo teor contestador do caráter da autoridade que os órgãos do poder judiciário exercem na vida política brasileira.

Quando a população atingir grau maior de reflexão política e se ver diante de um poder efetivamente intocável, aí é que a maturidade das instituições se mostrará importante. Os sistemas políticos não são,

e o povo como detentor do poder, como é, por exemplo, no Brasil. O povo é responsável por eleger seus líderes e pode, se desejar, retirá-los, bem como ele é responsável por determinar o que é o bem comum e todas as demais disposições políticas significativas para a sociedade, ainda que através de representantes. 
obviamente, fechados em suas características, e diversos povos que vivem sob sistemas democráticos têm magistraturas compostas por membros concursados, mesmo com alto grau de reflexão política, mas esta foi a solução dada por eles aos desafios diante deles postos. A democracia é o regime mais hostil possível à magistratura não passível de tutela popular, vez que a base da democracia é a submissão da política à vontade do povo. No Brasil a democracia não foi refletida, mas adotada romanticamente. Grande parte da população vive ao largo dela, sob estruturas de dominação absolutamente antagônicas à estrutura de dominação legal-burocrática do Estado. Quando este anacronismo se tornar claro para o brasileiro, aí sim a escolha política se dará conscientemente.

Nesta reflexão política, a figura do magistrado será melhor definida, tendendo para se encaixar ora em uma posição de maior responsabilidade pessoal perante a sociedade ora em uma posição de maior autonomia a ele legitimamente conferida. Nos extremos, ambos os casos têm meios de responsabilização que mantém o cargo existente. Apesar de silencioso, o impacto desta definição será grandioso em diversos níveis de existência individual. Uma tendência, no entanto, já se pode vislumbrar, quando são questionados os privilégios da magistratura, de uma Justiça mais democrática. Por outro lado, quando a autoridade fala mais alto e consegue impor sua vontade enquanto corpo, é a independência do magistrado que é salvaguardada, em detrimento da vontade popular, mas não sem responsabilidade para o magistrado, que tem que justificar sua legitimidade (e a capacidade intelectual é um meio - por isso a implementação de cursos no âmbito dos tribunais, além de perguntas nas provas de acesso a carreira, que visam ter no magistrado não só a mera máquina de exarar decisions, mas também um indivíduo capaz de refletir acerca da Justiça). É possível um compromisso, sem dúvida, mas maior reflexão é necessária.

Outra questão a se ponderar é se os juízes detêm a razoabilidade exigida para o exercício da profissão. A maior parte da literatura jurídica, política e filosófica, da qual o maior exemplo é a de Aristóteles, apesar de não pôr a questão desta forma, exige a razoabilidade, fundada em um senso de equidade, como virtude pessoal do magistrado. Ratio seria a próprio meio de se alcançar a mesótes, o meio termo de uma virtude. Sendo a Justiça uma virtude, o meio para se alcança-la seria através da razão, do bom uso da razão. Mas a virtude é héxis, hábito, e, consequentemente, depende de sua prática. A sabedoria prática é o que faz do homem um bom julgador e tende a crescer com base em dois parâmetros, experiência de vida e, para Aristóteles especificamente, a prática de não se abandonar os fins aos quais se inclina o homem. Um meio de compensar esta exigência de experiência, que, em última instância, é uma exigência de idade, é exigir o conhecimento aliado à prática. Exige-se, enfim, o conhecimento da sabedoria dos outros, ou seja, conhecimento cultural (e aqui se remete ao conceito de Kultur alemão, ou seja, uma cultura ampla e universal, não só artística, mas artística, científica e propriamente filosófica, inclinada, obviamente, para as ciências não técnicas - se estas podem alterar a prática do jurista é só circunstancialmente, a não ser que aqui se inclua o próprio Direito enquanto técnica). No reinado da técnica, no 
entanto, fruto de um positivismo - e aqui se fala de uma prática que tende a alienar o Direito enquanto objeto de estudo e prática das outras ciências sociais e não do ramo filosófico - jurídico totalitário, muitas vezes o magistrado sequer pondera o thélos da Lei, ou seja, seu fim, sua razão de ser.

Verdade que esta reflexão poucas vezes altera o resultado de um julgamento e à Teoria Positivista do Direito se deve agradecimentos por racionalizar o sistema jurídico de aplicação da norma. Mas os poderes que são dados ao Poder Judiciário na contemporaneidade em diversos países exigem que o Juiz tenha esse amplo conhecimento, porquanto muitas vezes cabe a ele substituir o legislador na criação dos discursos normativos sociais, na própria confecção de normas, definindo os rumos da política nacional através de suas decisões (o que algumas vezes faz sem qualquer trecho da Constituição para embasá-la). São situações excepcionais que têm se tornado mais comuns e que, ainda que voltem a ser excepcionais, têm grave impacto na vida social no país.

\section{A ORIGEM DO DEVER DE VIRTUDE (TUGENDPFLICHT) E A RELIGIÃO COMO DEBITUM EM SUÁREZ}

Retornando ao cerne da questão, destas definições iniciais, extrai o autor a conclusão de que "a Igreja inventou o paradigma de uma atividade humana cuja eficácia não depende do sujeito que a põe em obra e que necessita dele, contudo, como de um 'instrumento animado' para realizar-se e tornar-se efetiva." (AGAMBEN, 2013a, p. 37) ${ }^{61}$

No entanto, é no "gerere" que o "círculo efetual entre ministerium e effectus" impacta a atividade jurídico-

\footnotetext{
${ }^{61}$ Assim, "[A] ação litúrgica (o officium em sentido lato) resulta do concurso de dois elementos distintos e, ao mesmo tempo, inseparáveis: o ministerium do sacerdote - o officium em sentido estrito, que age só como causa instrumental - e a intervenção divina - o effectus -, que o realiza e torna efetual [...] A ação é cindida em dois elementos, sendo que o primeiro deles, o ministerium (ou officium em sentido estrito), define somente o ser e a ação instrumental do sacerdote e, como tal, é apresentado em termos de humildade e imperfeição ('fragili officio [...] humilitatis nostrae ministerio'). O segundo, que realiza e aperfeiçoa o primeiro, é de natureza divina e, todavia, é, por assim dizer, inscrito e contido no primeiro, de maneira que o correto cumprimento da função sacerdotal implica de modo necessário e automático a realização do effectus (reconhece-se aqui a dualidade de opus operantis e opus operatum através da qual a escolástica definirá o mistério litúrgico). O effectus divino é determinado pelo ministério humano e este pelo effectus divino. Sua unidade efetual é o officiumefficium. Isso significa, porém, que o officium institui entre ser e praxe uma relação circular, pela qual o ser do sacerdote define sua praxe e esta, por sua vez, define o ser. No officium, ontologia e praxe tornam-se indecidíveis: o sacerdote deve ser o que é e é o que deve ser. O que está em jogo na estratégia de Ambrósio é, nesse ponto, perspícuo: trata-se de individualizar - para além dos princípios da ética antiga e, todavia, em continuidade com ela - um conceito pelo qual pensar e definir a ação do sacerdote e da Igreja em seu conjunto. Se o problema da Igreja primitiva era conciliar uma dignidade espiritual (a posse dos carismas) com a execução de uma função jurídico-burocrática e a celebração do mysterium divino com o cumprimento de um ministerium humano, o conceito ciceroniano de officium, que não designava um princípio ético absoluto, mas um "dever em situação" (segundo a fórmula que Durando toma de Isidoro: "proprius vel congruus actus uniuscuiusque personae secundum mores et leges civitatis vel instituta professionis' ['ato próprio ou congruente de qualquer pessoa segundo os costumes e as leis civis ou da profissão instituída']), fornecia um modelo coerente para fazer coincidir na medida do possível os dois aspectos." in AGAMBEN, Giorgio. Opus Dei: Arqueologia do Ofício. São Paulo: Boitempo Editorial, 2013, p. $87 / 9$.
} 
política, pensando-se com Varrão. ${ }^{62}$ Segundo Agamben:

Gerere, que equivale originalmente a "levar", na linguagem político-jurídico significa "governar, administrar, executar um encargo" (rem publicam gerere, gerere magistratum, honores, imperium). Com uma análoga evolução semântica, também o verbo sustinere adquire o significado político de "assumir um encargo" (munus sustinere in re publica). Enquanto, para Aristóteles, o paradigma da ação política é a praxe, gerere designa então o conceito especificamente romano da atividade daquele que é investido de uma função pública de governo. $\mathrm{O}$ imperator, o magistrado investido de um imperium, não age nem produz, sua ação não é definida, como o fazer, por um resultado externo (a obra) nem tem em si mesma seu fim: ela se define por seu próprio exercício, por seu assumir e executar uma função ou um ofício.

Nesse sentido, Varrão pode dizer que o magistrado "assume e sustenta" (sustinet) sua ação: vitalizando o círculo efetual entre munus e exercício, entre ministerium e effectus, a ação coincide aqui com a efetuação de uma função que resta a ela mesma definir. O gerereé, nesse sentido, o paradigma do officium.

(AGAMBEN, 2013a, p. 90)

A esfera do comando é o ato próprio do imperator em seu gerere e, concordando com Agamben, a natureza especial do comando "tem sentido somente enquanto toma por objeto e assume sobre si a ação de um outro (que supostamente deve obedecer, isto é, seguir o comando)."63

Se "na tradição aristotélica, o elemento que assegurava" a "passagem da potência para o ato e do ministerium para o effectus... era a hexis (em latim, habitus) ... Uma arqueologia do officium deverá, portanto, necessariamente confrontar-se com o modo pelo qual os teólogos, retomando a impostação aristotélica, articulam a doutrina dos habituse das virtudes." (AGAMBEN, 2013a, p.98)

Na Ética a Nicômaco, de Aristóteles, a virtude (aretē) é caracterizada como hábito (hexis - classificação esta que se dá por exclusão, pelas virtudes não poderem ser categorizadas como pathē - paixões - ou potências dynameis). "O hábito é, então, o modo no qual um ser (especificamente, o ser humano) 'tem' em potência uma técnica, um saber ou uma faculdade, 'tem' uma potência de saber e agir.” (AGAMBEN, 2013a, p. 99) Segundo Agamben, ainda, o hábito seria "o ponto no qual o ser transpassa o ter" (AGAMBEN, 2013a, p. 99) Explicitamente, Agamben, em acordo com a crença de Heidegger de que a kynēsis, o movimento, é o conceito fundamental de Aristóteles, afirma que a teoria da potência e do hábito é um modo de introduzir o movimento no

\footnotetext{
62 “[...] o imperator [o magistrado investido do poder supremo], com relação ao qual se usa a expressão res gerere, nisso não faz nem age, mas gerit, isto é, assume e sustenta [sustinet], termo transferido daqueles que levam os pesos (onera gerunt), na medida em que o sustentam." in VARRÃO. On the Latin Language. Org. Roland G. Kent, Londres/Cambridge (Mass.), Heinemann/Harvard University Press, 1967.2 v, p. 245 apud AGAMBEN, Giorgio. Opus Dei: Arqueologia do Ofício. São Paulo: Boitempo Editorial, 2013, p. 89.

${ }^{63}$ Por sua vez, "o fim de uma ação realizada para seguir uma ordem não é somente aquilo que resulta da natureza do ato, mas é (ou pretende-se que seja) também e antes de tudo a execução de uma ordem. (Por isso - ao menos até os processos que se seguiram à Segunda Guerra Mundial - pensava-se que aquele que obedece a uma ordem não deveria responder pelas consequências de seu ato). [...] Tanto aquele que segue uma ordem quanto aquele que realiza um ato litúrgico não são simplesmente nem simplesmente agem, mas são determinados em seu ser por seu agir e vice-versa. O oficial - como o oficiante - é o que deve e deve o que é: é, portanto, um ser de comando. A transformação do ser em dever-ser, que define tanto a ética quanto a ontologia e a política da modernidade, tem aqui seu paradigma." in AGAMBEN, Giorgio. Opus Dei: Arqueologia do Ofício. São Paulo: Boitempo Editorial, 2013, p. 90.
} 
ser.

Aristóteles, segundo Agamben, afirmaria não que "é bom", mas que "torna-se bom" (agathos gignetai): em questão, portanto, estaria "não só a passagem do ser para o ter, mas também do ser para o agir e do agir para o ser. [...] o virtuoso se torna o que é e é o que se torna." (AGAMBEN, 2013a, p. 100) ${ }^{64} \mathrm{O}$ hábito, por sua vez, seria "a forma especificamente humana da potência." (AGAMBEN, 2013a, p. 103) Consequentemente, segundo Agamben, é ordenação constitutiva do hábito à ação que a teoria das virtudes desenvolve ao máximo.

Aristóteles, no entanto, não cercava seus conceitos com a visão de mundo que fez com que sua filosofia fosse reinterpretada dentro do Cristianismo. Mas, desde o início do Cristianismo, forças operaram para trazer a ética aristotélica, que, se adianta, era a ética de um homem livre, mas enraizado em sua comunidade, para dentro de uma estrutura metafísica cristã, que, em uma de suas vertentes (qual seja, aquela que é mais apegada à letra do evangelho e repugna a incorporação de conceitos metafísicos pagãos e que acabou se consagrando na Reforma), é metateoricamente próxima ao estoicismo.

Não é tanto uma questão de dividir os pensadores em grupos rivais, mas reconhecer que seus pensamentos sobre determinadas matérias por vezes íam em uma direção, por vezes em outra, sem perder a coerência, porquanto sustentados por diversas interpretações filosóficas de um ou mais textos cujos autores haviam morrido séculos antes. É só com a Reforma que este campo vai se delinear melhor - e, ainda assim, não de forma definitiva. ${ }^{65}$

\footnotetext{
${ }^{64}$ Assim, "[J]ustamente porque Aristóteles pensa a ação a partir da potência-hábito, que mantém um nexo originário com a privação e a potência de não passar ao ato (echein kai mē energein, ter sem exercer), sua ética deve necessariamente terminar em uma aporia (isto é, em uma 'ausência de via'). A teoria da virtude, que deveria tornar possível a passagem, resta em sua essência uma etologia, ou seja, uma teoria da habitude-caráter, porque todos os elementos aos quais Aristóteles recorre para governar, através da virtude, a ação (como a escolha, proairesis, e a vontade, boulēsis) são evidentemente acidentais e, pressupondo um sujeito externo à potência, não têm nenhuma base no hábito que deveriam guiar. Por isso a virtude aristotélica se apresenta ora como uma propriedade ontológica (uma modalidade do hábito), ora como uma qualidade da obra e da ação, e uma mesma obra define tanto a hexis quanto a ação e seu sujeito ('uma mesma obra pertence tanto à coisa quanto à virtude, ainda que não do mesmo modo: assim, um sapato é obra tanto da arte dos calçados quanto da ação do sapateiro, pela qual, se há uma virtude sapateira e um bravo sapateiro, o bom sapato será a obra de ambos'). Pela mesma razão, Aristóteles pode afirmar que "o ergon é melhor que a hexis' e, ao mesmo tempo, sustentar, com perfeita circularidade, que 'quanto melhor é a hexis, tanto melhor o ergon'.

Daí resulta que o hábito é o lugar lógico no qual algo como uma teoria da subjetividade poderia ter nascido. O Bartleby de Melville, ou seja, por definição um homem que tem a potência de escrever, mas não pode exercê-la, é a perfeita das aporias da ética aristotélica. [...] É sobre o fundo aporético da ética aristotélica que a teoria escolástica das virtudes em sua relação com o officium torna-se plenamente inteligivel. A proximidade entre officium e virtude, que, já implícita em Cícero e Ambrósio, constitui a prestação específica da ética da escolástica tardia, possui, de fato, o escopo de conferir efetualidade à virtude no governo do hábito e da potência." in AGAMBEN, Giorgio. Opus Dei: Arqueologia do Ofíicio. São Paulo: Boitempo Editorial, 2013, p. 102.

${ }^{65}$ Por exemplo, do tratado sobre as virtudes de Tomás de Aquino, Agamben relata, a virtude é definida com um termo que recorda aquele (operatorius) com o qual Ambrósio havia definido a operatividade do verbo de Cristo, "hábito operativo" (habitus operativus) (AGAMBEN, Giorgio. Opus Dei: Arqueologia do Ofício. São Paulo: Boitempo Editorial, 2013, p. 104). E ainda: "Com relação à simples potência, que pode dispor-se tanto ao bem quanto ao mal, o hábito bom se distingue do mau não porque tem um objeto bom, mas porque está em harmonia com a natureza do agente ('habitus bonus dicitur qui disponit ad actum convenientem naturae agentis' ['diz-se hábito bom para aquele que dispõe para o ato condizente com a natureza do agente']). Do mesmo modo, a virtude implica a perfeição de uma potência, mas o mal não conhece perfeição e é, por assim dizer, constitutivamente 'enfermo' ('omne malum defectum quemdam importat; unde et Dionysios dicit quod omne malum est infirmum' ['todo mal implica algum
} 
A primeira vez que a relação essencial entre virtude e dever é formulada, ou seja, que a apropriação cristã da ética aristotélica a converte enquanto instrumento de uma nova ética compatível com uma ontologia da efetualidade (já determinada em seus paradigmas por uma interpretação estóica - eclética, na verdade, como se explicará mais adiante, da filosofia aristotélica, especialmente a filosofia moral aristotélica), é no artigo $2^{\circ}$ da Quaestio 81 (II,II, S.T.) Agamben o traduz:

Se a virtude, segundo a definição aristotélica, "é o que torna bom aquele que a possui e boas as suas obras", então toda ação boa pertencerá necessariamente à virtude. E porque, segundo toda a evidência, devolver a alguém o devido é um bem, a religião, que consiste no render a Deus a honra que lhe é devida, é por excelência uma virtude.

À objeção de que a virtude pressupõe uma vontade livre e não uma obrigação como aquilo que define o serviço que o homem deve a Deus, Tomás responde que "também um servo pode voluntariamente fazer o que deve a seu patrão, fazendo assim da necessidade virtude; do mesmo modo, exibir a Deus o serviço que lhe é devido pode ser um ato de virtude". E, "enquanto opera as coisas que diretamente e imediatamente são ordenadas em honra a Deus, a religião é a mais eminente das virtudes morais." ${ }^{\prime 66} 67$

É de Suárez, no entanto, que vem a tradição kantiana acerca do Dever (AGAMBEN, 2013a, p. 109), mas ela já se encontra no próprio Tomás de Aquino. Aquino já representa uma tradição modernista dentro do catolicismo, tendo seus escritos gerado bastante polêmica, ${ }^{68}$ e se Suárez é acusado de não ser muito fiel ao

defeito; daí que também Dionísio diz que todo mal é enfermo']). Portanto, se, em última instância, 'toda virtude é necessariamente ordenada ao bem, então também a virtude humana, que é um hábito operativo, será um hábito bom e operativo do bem [bonus habitus et boni operativus]." Complementa ainda Agamben, ao afirmar que "[D] ecisiva não é aqui a coerência do argumento, da qual se pode auferir a consequência de que não o bem define a potência, mas a perfeição ou a imperfeição desta determinam o que é bem e o que é mal. Essencial, ainda uma vez, é a efetualidade da virtude, seu tornar operativo o hábito. A bondade da virtude é sua efetualidade, seu impelir e orientar a potência em direção a sua perfeição. E esta não consiste, para o homem, no ser, mas no operar, e só através da ação o homem se assemelha a Deus: própria do homem não é a virtude com respeito ao ser [virtus ad esse], mas só aquela virtude que concerne ao agir racional, que é próprio do homem [...]. E porque a substância de Deus é sua ação, a suprema assemelhação do homem a Deus ocorre através de uma operação qualquer. Portanto [...] a felicidade ou a beatitude, através da qual o homem é maximamente conforme a Deus, que é o fim da vida humana, consiste em um operar [in operatione consistit]." in AGAMBEN, Giorgio. Opus Dei: Arqueologia do Ofício. São Paulo: Boitempo Editorial, 2013, p. 104. Assim "[O] sacerdote deve realizar seu ofício enquanto é sacerdote, mas é sacerdote enquanto realiza seu ofício. E, assim como o sujeito do ato litúrgico não é verdadeiramente tal, mas é movido por Cristo ex opere operato, o sujeito do ato virtuoso é movido pelo hábito operativo, tanto que Tomás pode escrever que, na virtude, 'Deus opera em nós sem nós' ('Deus in nobis sine nobis operatur'). Não surpreende, então, que, na pessoa do sacerdote, virtude e ofício entrem em uma tenaz constelação. Por isso, já a partir de Ambrósio, os tratados sobre o ofício sacerdotal são também tratados sobre as virtudes do sacerdote. Tanto o ofício quanto a virtude são retidos no mesmo círculo: o bom (o virtuoso) é tal porque age bem e age bem porque é bom (virtuoso).” in AGAMBEN, Giorgio. Opus Dei: Arqueologia do Ofício. São Paulo: Boitempo Editorial, 2013, p. 106.

${ }^{66}$ AGAMBEN, Giorgio. Opus Dei: Arqueologia do Ofício. São Paulo: Boitempo Editorial, 2013, p. 106. Os termos em latim foram omitidos, sempre que presente a tradução.

${ }^{67}$ Agamben comenta, ainda: "Reflita-se sobre o singular paradigma prático que está em questão aqui e parece constituir de qualquer maneira o modelo do 'dever de virtude' (Tugendpflicht) kantiano e pré-kantiano. No conceito de uma virtude cujo único objeto é um debitum, de um ser que coincide integralmente com um ter de ser, virtude e officium coincidem sem resíduos. O 'dever-ser' é, portanto, o dispositivo que permite aos teólogos resolver a circularidade entre ser e agir na qual restava presa a doutrina das virtudes. $\mathrm{O}$ ato realizado graças à inclinação operativa do hábito virtuoso é, na realidade e na mesma medida, a execução de um dever. Fazendo literalmente 'da necessidade virtude', o religioso é, ao mesmo tempo, inclinado ao dever e obrigado à virtude." in AGAMBEN, Giorgio. Opus Dei: Arqueologia do Ofício. São Paulo: Boitempo Editorial, 2013, p. 108.

${ }^{68}$ Villey, sendo bastante parcial, afirma que "há várias Idades Médias", uma "alta Idade Média", que afirma "sombria com efeito e, quanto às ideias, dominada pela ditadura da fé e da letra da Escritura; depois, a partir do século XI ou do século XII, em alguns locais privilegiados, um novo período; [...] surgem as cidades, as corporações de comerciantes e artesão; renascem Estados, uma vida 
tomismo por Villey, ele é, no entanto, considerado um dos principais doutrinadores tomistas da escolástica tardia pelos seus pares. ${ }^{69}$ A definição de Suárez de religião ${ }^{70}$ não nega a correção deles, mas, como Villey pontua, o nominalismo impactou o pensamento do pensador espanhol (e, como sempre, é importante lembrar que estas escolas, nominalistas e realistas, não representavam dois partidos políticos, de forma que as filosofias produzidas no seio delas dialogavam entre si em diversos pontos).

Considerando estes dados e a importância do nominalismo dentro da formação do pensamento éticojurídico moderno, a próxima seção será dedicada a seu estudo.

política intensa, rica em controvérsias, criativa, e que é tudo menos 'estática'; tem-se, enfim, o desenvolvimento dos estudos e da razão, em Chartres, em Bolonha, em Paris."

Ele explica que há na história universitária da segunda dessas "Idades Médias" duas grandes escolas: "- Uma corrente humanista, particularmente receptiva à filosofia profana: Chartres, Abelardo, os intérpretes de Cícero e do direito romano, de Aristóteles ou de Averróis. Essa 'escola' atinge seu auge com a síntese, aliás moderada, de são Tomás. - Há também uma corrente que chamamos de integrista, mais ligada à tradição estritamente cristã, sobretudo a santo Agostinho. Ela atravessa toda a Idade Média e, no século XIII, invade particularmente a escolástica franciscana. Por volta de meados desse século, ela talvez se veja um pouco eclipsada pelo maravilhoso sucesso da doutrina de são Tomás. Mas, após a condenação deste último, em 1277, retoma a ofensiva e floresce no começo do século XIV com os sistemas teológicos de Duns Escoto e Guilherme de Ockham. [...] cada uma dessas duas escolas colocou uma pedra para a construção da doutrina jurídica moderna. É sem dúvida principalmente de Guilherme de Ockham e da escola nominalista que procede o individualismo que, a nosso ver, é sua principal característica. Existe um vínculo direto e contínuo entre Ockham (e, em menor escala, Duns Escoto) e os profetas por excelência do pensamento moderno que, nos séculos XVI e XVII, serão Lutero, Descartes, Hobbes ou Pufendorf." Ambos os trechos in VILLEY, Michel. A Formação do Pensamento Jurídico Moderno. São Paulo: Editora Martins Fontes, 2009, p. 179.

${ }^{69}$ "Oficialmente, Suárez adota as opiniões de são Tomás. O geral dos jesuítas intimou-o a seguir a ordem da Suma, e, aliás, essa política vem de uma decisão de princípio do próprio Inácio de Loyola: esse é o caminho mais seguro para se precaver contra os desvios do protestantismo e permanecer na tradição, e também, como é lembrado nas diretrizes oficiais, para evitar em Salamanca querelas e controvérsias com os mestres dominicanos igualmente desagradáveis e nocivas para o triunfo da causa comum. Numa carta do geral da Companhia, datada de 1610, leio que o padre Francisco Suárez é considerado tão tomista que, por esse motivo e também pela certeza tão grande de suas opiniões, sua doutrina parece geralmente ser seguida nas principais universidades da Europa'. Essa reputação não podia ser totalmente injustificada, tanto mais que ela ainda persiste. Mas, como já assinalei, trata-se de algo que é objeto de controvérsias candentes [...] a ortodoxia tomista de Suárez me parece ainda mais contestável que a de Vitoria. [...] E quanto às conclusões de Suárez, constituem em geral um meio-termo entre são Tomás e seus adversários, uma tentativa de síntese, a que devia logicamente conduzir o emprego do método escolástico. Digamos, antes, que elas são um indício de seu ecletismo: Suárez dificilmente opta entre as autoridades adversas e seu esforço é antes o de conciliá-las, combiná-las, procurar reunilas. [...] imagino Suárez realizando seu trabalho de mistura da filosofia de são Tomás com a de Escoto ou de Ockham; mas uma mistura em que, no tocante ao fundo, o nominalismo predomina." in VILLEY, Michel. A Formação do Pensamento Jurídico Moderno. São Paulo: Editora Martins Fontes, 2009, p. 400 e ss..

70 "o nome da religião se pode assim explicar corretamente: porque a criatura racional é ligada por um débito natural e por uma íntima inclinação a oferecer um culto ao seu autor, ela é ligada novamente [religatur] por uma escolha voluntária e por um hábito a ela acrescida. Por isso a virtude que cumpre esse officium pode-se chamar religio." in SUÁREZ, Francisco. Opera Omnia. (org, Charles Berton) Paris; Vivès, 1859, v. 13, p. 5 apud AGAMBEN, Giorgio. Opus Dei: Arqueologia do Ofício. São Paulo: Boitempo Editorial, 2013, p. 110. Com base no extrato, comenta Agamben: "Graças a essa coincidência de virtude e dever, nos capítulos sucessivos o debitum pôde ser constituído como 'definição e objeto formal' ('ratio et objectum formale') da religião. Assim, o que define a religio como virtude não é simplesmente o fato de que, através dela, são prestados a Deus culto e honra, mas que estes the são prestados somente na medida em que são devidos: 'a função da justiça é render o devido, mas a religião é parte da justiça [...] portanto, a honra e o culto de Deus reingressam na religião só na medida em que são devidos [honor et cultus Dei non cadit in religione, nisi ut ei debitus]'. Por isso, contra aqueles que distinguem o dever religioso (que se deve a Deus em razão somente de sua excelência) do legal (que deriva também de um preceito jurídico), Suárez afirma a natureza propriamente legal do debitum religionis: 'a religião [...] rende a Deus o culto que lhe é devido por seu direito [iure proprio illi debitum] e portanto o dever que ela cumpre não é genericamente moral, mas próprio e legal [non utcumque morale, sed proprium et legale]. Na ideia de um ser que se resolve integralmente em um débito, em um ter de ser, direito e religião coincidem necessariamente." 


\section{O PAPEL DO NOMINALISMO NA CONSTRUÇÃO DO PENSAMENTO JURÍDICO MODERNO A PARTIR DA ÓTICA DA RELAÇÃO ENTRE ESTADO E SUJEITO}

Ockham, monge britânico e filósofo, é quem traduz melhor o conceito de nominalismo. A grande tensão que há em seu pensamento é reflexo de uma tensão real existente entre ordem-direito-vontade. Não cabe aqui explicar detalhadamente a Querela dos Universais, mas, basicamente o que Ockham faz é levar ao extremo um movimento apenas esboçado por Aristóteles contra Platão, desprezando o geral em benefício do singular. $\mathrm{Na}$ interpretação de Ockham, só indivíduos existiriam, nunca noções universais enquanto realidade substantiva (ou seja, existir mesmo só existem as árvores que estão no mundo, não a noção de árvore, a ideia de uma árvore com todas as perfeições de umas árvores ou como parâmetro para julgar se algo é uma árvore ou não - VILLEY, 2009, p. 229). A tese do realismo, defendida moderadamente por Tomás de Aquino, reconhece, no mesmo sentido de Aristóteles, a existência em primeiro lugar de uma realidade para os indivíduos. Mas também considera reais (por isso o "realismo" no sentido escolástico da palavra) os "universais". Eles não são apenas conceitos, são "substâncias segundas" (a substãncia primeira é a do indivíduo). Mas isso é, também, um "semi-realismo", mais fiel a doutrina aristotélica e que incorpora uma noção de ordem transcendente ao mundo e uma ordem entre as coisas do mundo (relações de causalidade definidas a partir de uma hierarquia entre ordem transcendente e ordem imanente - VILLEY, 2009, p. 227).

A questão, para Ockham, não era tanto negar a existência de uma ordem, mas vincular a inteligibilidade da ordem à expressão da vontade da autoridade e, neste sentido, já havia um caminhar inegável para o pensamento moderno. Debatendo com o Papa João XXII acerca da questão da existência de um poder absoluto de Deus não correspondendo ao seu poder ordenado no mundo, ele defende posição semelhante à de Escoto, ${ }^{71}$ contra o Papa, por crer que qualquer Autoridade sempre preserva o que se referiu mais acima como característica própria do Bartleby de Melville, ou seja, a contingência, a opção do não fazer como fez no momento da decisão. O que é propriamente absoluto do poder, ainda que se esvaia na decisão, não pode ser desconsiderado, sob pena de se

\footnotetext{
${ }^{71}$ Sobre Duns Escoto, Villey afirma que seu pensamento "está marcado por sua desconfiança em relação à ideia de ordem natural. Falar da 'ordem natural' é correr o risco de cometer, aos olhos de Duns Escoto, um crime de lesa-majestade divina. Pois supor uma ordem natural necessária é, evidentemente, diminuir o poder de Deus, como fazem esses teólogos que, tal como são Tomás, embora atribuam a razão, a 'sabedoria' a Deus, afirmariam que Deus é obrigado a sempre agir dentro da ordem. Isso equivale a subordinar Deus a um ídolo, a uma Natureza, imaginada em pé de igualdade com a razão humana, fruto do orgulho intelectualista. A fé e a meditação inspiram, ao contrário, em Duns Escoto a ideia de um Deus onipotente, absolutamente livre em relação a qualquer ordem preconcebida. Os temas da onipotência e da transcendência de Deus (ou, como diz ele, de sua potestas absoluta) estão entre aqueles que lhe são mais caros. Essa expressão já se encontrava na Suma de são Tomás; mas são Tomás questionava o 'poder absoluto' de Deus no sentido de que, sendo Deus sábio, ele só poderia agir dentro dessa ordem; seu poder seria 'ordenado' (potestas ordinata). Duns Escoto inverte essa tese: Deus age com total liberdade, não está obrigado pela razão, pois é o criador de tudo, até mesmo da razão; sua vontade está acima, antes da razão, e seus desígnios, diz a Escritura, são insondáveis para nós. Concebamos, portanto, sua potestas como absoluta (poder absoluto)." in VILLEY. Michel. A Formação do Pensamento Jurídico
} 
reduzir o poder ao puro agir na necessidade (não de sobrevivência, mas, como o próprio Ockham se referia a esta forma de pensar, como pensam os muçulmanos - ou seja, um poder que só age de uma forma já prevista, que não é verbalmente um poder, não é contingente). ${ }^{72}$ Sempre deveria haver, para Ockham, a opção de agir fora da ordem, enquanto compreensão intelectual do mundo. ${ }^{73}$

Moderno. São Paulo: Editora Martins Fontes, 2009, p. 203.

${ }^{72}$ Esta discussão entre João XXII e Ockham se dá, para Agamben, em uma perspectiva que envolve uma série de outros fatores, como a Lenda do Graal, a Decretal Grandi, do Papa Inocêncio IV e as doutrinas gnósticas do Deus Ocioso, todos relacionados a tentativa de compreensão da relação entre o exercício do poder e o poder em si, ou seja, entre o Governo e o Reino. Enquanto o Papa João XXII defende uma posição mais tradicional, de indistinção, Ockham crê que o Reino deve sempre ser maior e preceder o governo, deve, sob pena de estar sempre agindo conforme a necessidade e se perder a contingência.

${ }_{3}$ "Podemos agora compreender melhor o mitologema Arthuriano do roi mehaignié. É o reflexo no campo literário de uma transformação e cisão do conceito de soberania que deve ter perturbado profundamente as mentes da época. Embora, como já vimos, ele tivesse alguns precedentes na doutrina gnóstica do deus ocioso e alguns paralelos na tradição do direito romano, esta transformação é realizada essencialmente, de um ponto de vista técnico, no campo da canonística. O modelo teológico desta separação é a doutrina da impotência divina, isto é, a distinção entre potentia absoluta e potentia ordinata. Hugo de Pisa e a decretal Grandi - com a qual Inocêncio IV, no caso do rex inutilis Sancho II, separou a majestade do rei (sua realeza) do exercício do poder real - deram a esta distinção a forma jurídica de cujos sentido geral e implicações políticas eles não estavam plenamente conscientes. No entanto, é certo que, como já foi observado, 'Grandi, na verdade, continha os resultados da mais articulada tradição legal que a Europa tinha visto desde a época de Justiniano, mas poucas monarquias territoriais eram capazes, em 1245, de aproveitar na sua totalidade essa tradição' (Peters, p. 304). O conflito que estava aqui em questão não é, no entanto, tanto entre 'autoridade legal' (que, devido à decretal, passou ao conde de Boulogne) e 'lealdade pessoal' (que ainda era devida ao soberano, Sancho II), mas entre uma soberania inseparável de seu exercício e uma realeza que é estruturalmente dividida e separável do governo (ou, em termos foucaultianos, entre a soberania territorial e poder governamental). É nesta perspectiva que conseguimos interpretar o debate que nas primeiras décadas do século XIV, opõe João XXII a Ockham. De acordo com João, as leis que Deus estabeleceu são idênticas à sua essência e, consequentemente, são eternas e imutáveis. Portanto, ele não pode agir senão como ele escolheu agir. Poderes absolutos e ordenados são a mesma coisa, e sua distinção é puramente nominal. É absolutamente impossível para Deus salvar, com base em seu poder absoluto, um homem desprovido do sacramento do batismo, porque isto foi decidido desde a eternidade de acordo com o poder ordenado, que é para ser identificado com Deus e não pode ser alterado [...] Alguns afirmam que Deus pode fazer muitas coisas com base no poder absoluto que ele não pode fazer com base no poder ordenado, mas isso é falso e errado, pois o poder absoluto e o poder ordenado são a mesma coisa em Deus e podem ser distinguidos apenas pelo nome, como Simão e Pedro, que nomeiam a mesma pessoa. Assim como é impossível que alguém bata em Simão sem bater em Pedro, ou que Pedro faça algo que Simão não faça, na medida em que eles são o mesmo homem, é também impossível para Deus fazer de acordo com o poder absoluto coisas diferentes das que faz com o poder ordenado, pois eles são a mesma coisa e são diferentes e podem ser distinguidas apenas em nome. (Citado em Courtenay, p. 162) O que Ockham propõe contra esta tese é a irredutibilidade do poder absoluto ao poder ordenado: estes não são dois poderes, mas duas maneiras diferentes em que dizemos que Deus pode ou não pode fazer algo, ou duas articulações internas de uma única potência divina em relação ao acto. Se olharmos de perto para esta questão, dizer que Deus pode fazer coisas de acordo com o poder absoluto que ele não pode fazer de acordo com o poder ordenado significa nada mais do que dizer Deus pode fazer coisas que ele não tinha decidido fazer [quae tamen minime ordinaret se facturum ]. Mas se Ele fosse fazer estas coisas, ele as faria segundo o poder ordenado, pois se ele as fizesse, ele eria decidido fazê-las (Citado em Courtenay, p.164) Para Ockham, como um pensador mais moderno, é essencial preservar a contingência da decisão contra uma compreensão da ação, professada pors Muçulmanos e 'velhas' (vetulae), que a reduz a pura necessidade ('a partir disto seguiria que nenhuma criatura poderia fazer qualquer coisa que ele não fizesse, fazendo com que tudo acontecesse de acordo com a necessidade e nada de uma maneira contingente, como os infiéis afirmam, e os hereges antigos, e também os hereges ocultos, as baladas e as velhas'; citado em ibid.). O que está em jogo neste conflito é, em última análise, o funcionamento da máquina governamental. Enquanto que, para o pontífice, a diferença entre os dois níveis ou momentos do aparato é puramente nominal, de modo que o ato de real governo sempre já determina o poder, e o Reino é plenamente identificado com o Governo, para Ockham, o Reino ( poder absoluto) excede e sempre de alguma maneira precede o Governo (o poder ordenado), que o alcança e o determina apenas no momento do executio ação, sem nunca esgotá-lo completamente. Em outras palavras, duas concepções diferentes de governo dos homens se confrontam: o primeiro ainda é dominado pelo velho modelo da soberania territorial, que reduz a dupla articulação da máquina governamental a um momento puramente formal; a segunda é mais próxima do novo paradigma econômicoprovidencial, em que os dois elementos mantém a sua identidade, apesar 
Agamben relata que a doutrina do poder absoluto divino, de Escoto e de outros teólogos, e sua diferença em relação à noção do poder ordenado está vinculada à elaboração de um instrumento conceitual que corresponderia à ideia de poderes excepcionais, que tornariam possível que se agisse para além da lei e mesmo contra ela, lei aqui no sentido tradicionalmente utilizado por estes autores, ordem universal (ou seja, uma lei natural, não positiva - desde a lei física para o universo físico, como a lei humana para a comunidade política e a lei religiosa para a humanidade - AGAMBEN, 2011, p. 109). A única limitação, não de potência, mas de legitimidade, seria de se agir contra uma ordem superior a si (por exemplo, um homem que se insurja contra a gravidade).

Estes instrumentos, portanto, a priori, não devem ser entendidos como criações voltadas para a utilização na política, mas sim para a reflexão intelectual acerca da realidade, divina e natural. No entanto, em relação a comunidade política, Villey que explica como funciona o sistema: "A ordem proveniente da vontade divina, promulgada na Sagrada Escritura, o texto positivo divino terá um lugar privilegiado entre as regras jurídicas. Mas, logo abaixo, já que as liberdades do homem também voltam a ser valorizadas e sua vontade é libertada dos entraves da razão, não menos soberanas serão as leis positivas humanas." (VILLEY, 2009, p. 209)

Neste sentido, deve-se compreender, antes de se prosseguir, a alteração do significado do Direito que se dá principalmente na teologia franciscana, e que afeta de forma profunda a ideia de Direito de Suárez. Michel Villey define como dois os traços principais do pensamento jurídico moderno a laicidade ${ }^{74}$ e o individualismo. ${ }^{75} \mathrm{~A}$

de sua correlação, e a contingência dos atos de governo corresponde à liberdade da decisão soberana. E, no entanto, por causa de uma inversão peculiar, este mesmo paradigma que é, por assim dizer, mais 'democrático' também está perto da posição desses canonistas e teólogos (como Duns Escoto) que, na mesma época, elaboravam a doutrina da potentia absoluta como um modelo para poderes excepcionais [poteri eccezionali]. Na medida em que poder estruturalmente excede o poder ordenado [potenza ordinata], o poder absoluto [potenza assoluta] é - não só em Deus, mas em qualquer agente (e, em particular, no Papa) - o que permite que se aja legitimamente 'para além do lei e contra ela'." In AGAMBEN, Giorgio. The Kingdom and the Glory. For a Theological Genealogy of Economy and Government (Homo Sacer II, 2). Stanford: Stanford University Press, 2011, p. 106.

${ }^{74}$ Este laicismo não é antirreligioso. "Muito pelo contrário, por algum tempo ele caminha passo a passo com a mais autêntica teologia cristã (e às vezes até católica). Os grandes filósofos do direito do século XVII, Suárez, Grócio, Locke, Pufendorf - e mesmo, a seu modo, Espinosa -, continuam sendo teólogos; têm a viva preocupação de harmonizar sua doutrina do direito com a religião cristã, multiplicaram as citações da Sagrada Escritura para fundamentar sua posição. É verdade que o protestantismo dota alguns de seus representantes de uma teologia laxista, livre de qualquer autoridade e cada vez mais indiferente em matéria de dogma (embora comumente acompanhada de uma piedade profunda) [...] Pouco a pouco, no entanto, sobretudo com Espinosa e com a filosofia do século XVIII francês, far-se-á notar a ruptura em relação à ortodoxia. Logo se produzirão as ondas do racionalismo e, mais tarde (tomando conta até do campo anglo-saxão do empirismo), do cientificismo moderno, no que eles têm de mais contrário à fé cristã." O que ocorre é que "[A] fé nos textos revelados, que era considerada pela opinião medieval como o primeiro meio de conhecimento, é totalmente substituída, pelo menos em se tratando de descobrir ou inventar o direito, pela confiança na razão, ajudada ou não pela experiência exclusivamente sensível. Dessa forma, foram construídos tantos os sistemas jurídicos de Hobbes como os de Pufendorf ou de Wolff. Há, com certeza, algumas exceções: a doutrina do direito de Lutero, de certos puritanos na América do Norte, a política de Bossuet, dita 'segundo a Sagrada Escritura'; um Domat aparenta fundar seu sistema do direito sobre princípios revelados. Mas a grande maioria dos autores modernos adota um procedimento puramente racional. Nesse mesmo sentido, a finalidade que a maioria atribui ao direito e ao Estado é puramente terrena, puramente mundana; e a recusa a considerar os fins espirituais do Além marcará o utilitarismo." Esta confiança na razão é, no entanto, limitada, como se verá, a campos de conhecimento que estes autores consideram serem passíveis de enfrentamento a partir da razão. A razão reina absoluta, mas em um 
laicidade é definida pelo paradigma epistemológico que afirma a inexistência de uma ordem transcendente que organize o mundo, gerando um rompimento entre fé e razão - ou seja, as verdades da fé, as leis da fé não têm uma justificativa que transcenda a própria vontade divina.

Em síntese:

[...] o nominalismo de Ockham levava a um corte brutal entre filosofia e fé: a filosofia natural e a razão têm por domínio a criação, só a fé é meio de acesso a conhecimento de Deus. 'Os dogmas da fé não são matéria de demonstração, e não são suscetíveis de prova: são até mesmo falsos para a maioria ou mesmo para a totalidade dos sábios deste mundo, dos sábios da filosofia.' (Summa totius logicae, III, I.). O protestantismo de Lutero (e mesmo, em menor medida, o de Calvino) tem, como se sabe, suas raízes longínquas em Ockham. (VILLEY, 2009, p. 232)

Aqui, novamente, há a separação absoluta entre a razão e a fé. À razão cabe imperar absolutamente nas coisas deste mundo, mas só nas deste. O que deve ser lembrado é que estes pensadores todos eram, como Villey afirmou, religiosos, mas o processo que eles iniciam, de abandono de uma metafísica transcendental fundada na verdade revelada, é que será plenificado no racionalismo cartesiano, no empirismo sensualista humeiano e, por fim, no kantismo.

É neste berço que nasce a doutrina kantiana. Ambos os traços que destacou, o próprio Villey o reconhece, "têm aliás, sua verdadeira origem na escolástica medieval, embora, com efeito, ainda dissociados." (VILLEY, 2009, p. 178) E esta transição que aqui é resumida, entre os grandes sistemas da filosofia antiga e medieval, que, enquanto tais, envolviam concepções propriamente jurídicas voltadas para a consecução da Justiça (entendida esta enquanto virtude), e os grandes sistemas da filosofia moderna, exemplificados pelos teóricos abordados por Agamben, e que atingem seu ápice na filosofia kantiana (que se utiliza de um vocabulário muito próprio dos sistemas normativos para descrever a relação sistêmica entre ser e dever-ser, principal tensão de sua ontologia), se dá em paralelo a uma mudança nas formas de organização política na Baixa Idade Média, que se descreverá no próximo capítulo, e na qual a busca de relações de causalidade se faz necessária, quando esta relação não é explícita.

Villey afirma que há muitos estudos conduzidos por juristas e dedicados à filosofia de Escoto,

território muito menor. Ambas as citações de VILLEY, Michel. A Formação do Pensamento Jurídico Moderno. São Paulo: Editora Martins Fontes, 2009, p. 175-6.

$75 \mathrm{O}$ individualismo, por sua vez, é o que, para Villey, “[...] opõe o direito moderno não só às concepções dominantes da Idade Média, mas também às doutrinas clássicas da filosofia do direito da Antiguidade (ou seja, sobretudo de Aristóteles)." Villey afirma que o mundo jurídico moderno tem certas premissas que revelam este caráter individualista: existência de "direitos naturais" do indivíduo. Hobbes, Locke, Pufendorf, Thomasius, Wolff, levando até a produção das Declarações dos Direitos do Homem; "construção artificial do Estado pelo contrato social, no interesse, para a utilidade dos indivíduos; positivismo jurídico (no sentido originário da palavra) que é o corolário da tese do contrato social e do estado de natureza anárquico: pois, se o indivíduo é livre no estado de natureza e a natureza não regula as relações sociais, não pode haver outro direito senão aquele disposto pelo Estado (há bastante positivismo, atenuado pelo reconhecimento de uma camada superior de direito natural, até mesmo na escola do direito natural); - enfim, o elemento primordial do sistema do direito (tanto positivo como natural) passa a ser a noção do direito subjetivo, de que a teoria do contrato constitui apenas um prolongamento; e também seu sucesso acaba sendo universal." In Ibid., p. 
sublinhando como ela tem como consequência lógica o positivismo jurídico, isto é, a soberania absoluta da lei positiva no direito. ${ }^{76}$ Se à vontade é dada primazia sobre a razão na gestão da ordem do mundo, ou seja, se a ordem é a mera vontade de Deus (ou do rei, no mundo), que espaço há para o direito natural? Só há espaço para a delimitação de competências - quem manda no cosmos é Deus; no reino, o rei; em si, o homem.77

O nominalismo franciscano representa então o posicionamento da vontade como elemento determinante da ontologia, a ponto de já se identificar na própria ideia de Escoto elementos que, ainda que desde sempre presentes, haviam sido enterrados por uma ontologia mais estática, fundada no Ser (Sein, esse, einai). Neste sentido, Anton Schütz, comentarista de Agamben, reafirma esta posição de Escoto, ${ }^{78}$ com base no texto de Agamben acerca da personagem Bartleby de Melville, figura que é reinvocada ao se falar do possível surgimento de um teoria da subjetividade que restara soterrada em Aristóteles,

que é tratada em Escoto como vontade, mas que "não é tanto a decisão quanto a experiência do constitutivo e irredutível copertencimento entre poder e poder não, entre querer e querer não."79

\begin{abstract}
176-7.
${ }^{76}$ Em são Tomás, ao contrário, a lei positiva ocupa apenas um lugar secundário, é apenas uma das fontes do direito - apesar dele já incorporar mais claramente uma ontologia da efetualidade, revelada em seu tratado sobre as virtudes, como já visto.

77 “No pináculo da moral social, Duns Escoto situa, como vimos, preceitos positivos divinos: 'Não matarás', 'Não roubarás', 'Não cometerás adultério' - já que, a seus olhos, esses preceitos são mais positivos que racionais. O assassinato, o roubo, o adultério são pecados segundo Duns Escoto porque Deus assim quis (mala quia prohibita); não estão proscritos por serem maus (prohibita quia mala), como, ao contrário, era o caso na doutrina de são Tomás. Portanto, para encontrar o conteúdo do direito, é preciso fixar-se no texto da proibição divina, e não mais nos raciocínios fundados na natureza das coisas: por exemplo, segundo Duns Escoto, a pena de morte só será admita nos casos ('tais como blasfêmia, o homicídio, o adultério e vários outros') expressamente prescritos por Deus na lei antiga." in VILLEY. Michel. A Formação do Pensamento Jurídico Moderno. São Paulo: Editora Martins Fontes, 2009 , p. 208.

78 "A contingência, na tradição do pensamento ocidental, é um tema que traz um potencial inesgotável. Ele fornece a Agamben especialmente em um trabalho dedicado a essa criação mais filosófica do mais filosófico dos escritores americanos, Bartleby, o escrevente: Uma história de Wall Street (1853), de Herman Melville - uma ocasião para testar a ligação entre um ingrediente atemporal da história da filosofia ocidental por um lado, e, por outro lado, a evolução de uma série de discussões particularmente impactantes no contexto da proto-história da sociedade ocidental moderna: especificamente, o debate sobre o poder de Deus e a distinção de dois poderes distintos atribuídos a Deus, potentia dei ordinata e potentia dei absoluta, a potencialidade ordenada de Deus e a potencialidade absoluta de Deus. A dupla conceptualização adquiriu sua relevância histórica através de escritos de alguns dos mais notáveis e controversos pensadores franciscanos do final do século XIII e do início a meados do século XIV; Traça uma linha de distinção entre o poder de Deus como sujeito a uma ordem (que no caso de Deus só pode ser a ordem já desejada por Ele mesmo) e o poder de Deus como isento de qualquer sujeição - de tal forma que a maneira de agir de Deus permanece de acordo, por assim dizer, com a ordem prevista e adotada (assim querida) por Sua própria escolha, ou, pelo contrário, considerando a Sua onipotência, permanece indefinidamente livre de qualquer vínculo. 'Por contingente', Agamben cita do escocês, 'não quero dizer algo que não é necessário ou eterno, mas algo cujo oposto poderia ter acontecido no mesmo momento em que aconteceu'. É na encruzilhada dessa contingência ilimitada com a noção de um poder divino igualmente ilimitado que Agamben localiza a gênese da modernidade ocidental." (tradução livre) In MURRAY, Alex e WHYTE, Jessica (Orgs.). The Agamben Dictionary. Verbete Contingency. Edimburgo: Edinburgh University Press, 2011. P. 50.

${ }^{79}$ Explica-se: "[S] egundo a fórmula lapidar à qual ele confia o único sentido possível da liberdade humana: experitur qui vult se posse non vele, aquele que quer faz a experiência de poder não querer." Assim, “apenas a vontade é indiferente aos contrários (voluntas sola habet indifferentiam ad contraria)', uma vez que 'tem em seu poder, em relação a um mesmo objeto, tanto o querer quanto o não querer, os quais, não obstante, são contrários'. Sem retroceder diante das consequências dessa tese, Escoto estende o caráter contingente de todo querer também à vontade divina e ao seu ato de criação: 'No mesmo ato de vontade, Deus quer os contrários, não que eles existam ao mesmo tempo, pois isso é impossível, mas ele os quer ao mesmo tempo; da mesma forma, é por meio de uma mesma intuição ou de uma mesma ciência que ele sabe que os contrários não existem ao mesmo tempo e que,
\end{abstract}


Sem traçar um histórico mais amplo, quando, enfim, a metafísica da vontade encontrar sua melhor expressão no pensamento moderno:

não se deve esquecer que o conceito de vontade foi introduzido na ontologia entre os séculos III e IV, porque a concepção do ser vinha progressivamente se transformando em sentido operativo. Como o dever foi introduzido na ética para dar um fundamento ao comando, assim a ideia de uma vontade foi elaborada para explicar a passagem da potência para a efetualidade. [...]

Ontologia do comando e ontologia da operatividade são, portanto, estreitamente ligadas: [...] também o comando pressupõe uma vontade. Segundo a fórmula que exprime o comando do príncipe (sic volo, sic iubeo [assim quero, assim ordeno/ordeno o que quero]), "querer" pode somente significar "comandar" e "comandar" implica necessariamente um querer. A vontade é a forma que o ser toma na ontologia do comando e da operatividade. Se o ser não é, mas deve realizar a si mesmo, então ele, em sua própria essência, é vontade e comando; vice-versa, se o ser é vontade, então ele não é simplesmente, mas deve ser. (AGAMBEN, 2013a, p. 131)

Há, no pensamento de Escoto, a coerência característica de um grande sistema, que Villey expõe ao tratar

de seu "comentário de Oxford sobre as sentenças de Pedro Lombardo, sobre a origem do dominium e da autoridade política”. Duns Escoto, segundo Villey, descarta a tese tomista aristotélica da origem natural da propriedade bem como do poder político. Ele destaca que:

A natureza não fez 'distinção' das respectivas propriedades, os limites entre o meu e o teu, assim como tampouco investe alguém da autoridade política; o ponto de partida de Duns Escoto é a tese tradicional (que, aliás, não contradizia literalmente são Tomás) de que, na origem, todas as coisas eram comuns e os homens livres de toda dominação política.

Mas, então, de onde vêm os poderes de dominium e de governo? Em primeiro lugar, da permissão divina: Deus revogou o preceito da comunidade dos bens válido no estado de inocência e deu aos homens permissão para constituir propriedades. Eis o que compete ao direito positivo divino. E agora, qual será a fonte da distinção efetiva das propriedades? Afora alguns casos excepcionais da história judaica, em que essa distribuição é ditada por Deus ou pelos patriarcas, Duns Escoto afirma, evocando, aliás, nesse sentido um texto célebre de santo Agostinho, que a distribuição dos bens procede da lei positiva humana.

Essa lei positiva humana pressupõe o poder político; mas este tem sua fonte na convenção positiva dos membros da comunidade. Se são Tomás põe a ênfase nas razões de justiça e de utilidade que obrigam o homem, em direito natural, a constituir Estados e propriedades distintos e que, em grande medida, devem presidir às partilhas, Duns Escoto só tem olhos para as causas eficientes, para a ação voluntária do homem, para as convenções e as leis. (VILLEY, 2009, p. 209)

Mas, segundo Villey, o nominalismo também viria a invadir o direito. Ele implica o abandono do direito natural, centrando a relação virtual entre as coisas no mundo no indivíduo ${ }^{80}$ As normas jurídicas, por sua vez,

todavia, são conhecidos ao mesmo tempo no mesmo ato cognitivo, que é um só ato'." In AGAMBEN, Giorgio. Bartleby, ou da contingência. Belo Horizonte: Autêntica Editora, 2015. P. 39.

80 "Ou seja, do método que presidira, a nossos ver, à constituição da ciência jurídica romana e que a escolástica humanista acabava precisamente de restaurar no direito erudito da Idade Média - método que tomava como ponto de partida para a descoberta das soluções jurídicas a observação da Natureza e da ordem que dela emana. [...] o indivíduo (não mais a relação entre vários indivíduos) torna-se o centro de interesse da ciência do direito; o esforço da ciência jurídica tenderá doravante a descrever as qualidades jurídicas do indivíduo, a extensão de suas faculdades, de seus direitos individuais." in VILLEY. Michel. A Formação do Pensamento Jurídico Moderno. São Paulo: Editora Martins Fontes, 2009, p. 233. 
perdem lentamente sua vinculação com um conceito de natureza das coisas (VILLEY, 2009, p. 233). ${ }^{81} 8283$

Sobre a relação entre sociedade e Autoridade, Villey lembra que, para Ockham, da lei divina procedem, para o homem, potestates. Ockham recupera Duns Escoto, lhe dando, no entanto, uma extensão bem maior e tomando "o cuidado de retraçar com extrema minúcia a criação desses poderes, com os textos da Escritura em mãos. Trata-se de mostrar a origem do imperium (da soberania, da 'jurisdição temporal') e do dominium." ${ }^{84}$ Assim, diz Villey:

é a cascata de poderes, todos decorrentes do poder absoluto divino, hierarquicamente, por uma série de concessões sucessivas - cascata que reflete a pirâmide das concessões feudais. De alto a baixo da árvore, o conjunto da ordem jurídica é constituído por poderes, dos quais, a cada vez, saem normas, ligando os poderes uns aos outros. Há o direito subjetivo de Deus, sua potestas absoluta; e, acima, os jura poli, os poderes concedidos por Deus a cada um dos indivíduos, ainda não providos de sanções; mais acima, os poderes engendrados pelo direito

\footnotetext{
${ }^{81}$ Segundo Villey, "[T]odas as características essenciais do pensamento jurídico moderno já estão contidas em potência no nominalismo." in VILLEY. Michel. A Formação do Pensamento Jurídico Moderno. São Paulo: Editora Martins Fontes, 2009, p. 233.

${ }^{82} \mathrm{E}$ "[O $\mathrm{O}$ que é o positivismo jurídico? A expressão direito positivo (jus positivum; justitia positiva) nasceu, como vimos, na escolástica humanista, em Chartres, depois em Abelardo, em seguida entre os glosadores e na linguagem de são Tomás. É, aliás, a tradução do grego díkaion nomikón, porque a essência das leis (nómoi) de onde deriva esse justo consiste em serem dispostas (legem ponere), positivas. A ideia de direito positivo é, aliás, uma das peças do sistema clássico do direito natural. Mas, nesse sistema, embora exista um justo que deriva da lei, um justo disposto, positivo, é apenas uma fonte subsidiária, já que a primeira fonte do direito continua sendo a ordem da natureza, da qual o trabalho da jurisprudência extrai regras jurídicas. O positivismo jurídico é, ao contrário, a doutrina que exalta o direito positivo a ponto de pretender edificar sobre a lei, e apenas sobre a lei, o conjunto da ordem jurídica.
}

E é nesse sentido, o mais claro e mais autêntico, que o positivismo jurídico é produto do nominalismo. E que já faz parte da doutrina de Guilherme de Ockham. Como acabamos de dizer, Guilherme de Ockham apenas reconhece, como objeto de conhecimento, 'res positivae' singulares: isso quer dizer que ele também só pode reconhecer como fontes de direito fórmulas de leis, expressões de vontades individuais, e não mais a ordem da natureza. Guilherme de Ockham concebeu e até aplicou o positivismo jurídico." in VILLEY. Michel. A Formação do Pensamento Jurídico Moderno. São Paulo: Editora Martins Fontes, 2009, p. 235.

${ }^{83}$ Villey afirma que, apesar de existirem precedentes para este positivismo, como a doutrina de Agostinho e o sofismo na Grécia Clássica, nenhum deles consegue chegar perto do que faz Guilherme de Ockham, pois "na obra deste último, nota-se esse tipo de positivismo brotar de uma lógica, do culto da dialética e do gosto levado ao extremo pelo raciocínio mais estrito, solidário, na verdade, de uma metafísica e primeiro efeito, no direito, do nominalismo." in VILLEY. Michel. A Formação do Pensamento Jurídico Moderno. São Paulo: Editora Martins Fontes, 2009, p. 249.

${ }^{84}$ Segundo a análise de Ockham, esses direitos só são produzidos indiretamente. É preciso estabelecer em primeiro lugar que Deus concedeu ao homem, num primeiro estágio, o poder de apropriação. Era algo que não existia, como se sabe, nos primeiros tempos da história humana, no tempo da inocência primeira: então, tudo era comum; no sexto dia da criação, Deus só tinha concedido à espécie humana um dominium coletivo sobre animais e plantas; tinha instituído apenas poucos direitos individuais, somente o poder marital ou o poder paterno. Mas, após a queda, Deus teria revogado o comunismo originário e promulgado a potestas appropriandi'. Isso resulta de vários textos da Sagrada Escritura e, indiretamente, do Gênesis II, 15: 'Deus tomou o homem e o pôs no jardim do Éden para cultivá-lo.' Ora, só é possível cultivar individualmente, como Aristóteles bem mostrou. [...] Falta ainda distribuir as propriedades, algo a que a legislação divina raramente procedeu de modo direto. Isso só ocorre no Antigo Testamento, com a atribuição aos judeus da terra de Canaã. Mas, ao mesmo tempo que conferia a potestas appropriandi, Deus tomou o cuidado de dar ao homem um outro poder, a 'potestas instituendi rectores', o poder de instituir chefes - o que só pode ser feito, como vimos, pelo procedimento da eleição, do contrato social. E esses chefes terão por função, precisamente, determinar limites para as propriedades, para que elas possam existir juntas. Assim será explicada a origem de uma terceira camada de poderes [...] Pois o príncipe temporal recebeu, por delegação do povo, o poder legislativo, potestas condendi leges et jura humana, ao qual se junta o exercício da jurisdictio. Daí surgem as leis positivas, todo o positivismo humano que, como vimos, ocupa em Guilherme de Ockham o lugar da ordem natural falha e é fonte única de toda a ordem humana porque, daí em diante, como exige o nominalismo, o jurídico é o legal." in VILLEY. Michel. A Formação do Pensamento Jurídico Moderno. São Paulo: Editora Martins Fontes, 2009, p. 284. 
positivo humano, os jura fori. São todos poderes absolutos. Pode-se fazer uso deles ao belprazer, ou não usá-los, renunciar a eles: como os franciscanos renunciam a exercer sua potestas appropriandi. Pode-se entrar voluntariamente na condição servil, que é também uma renúncia a essa potestas. E, caso se faça uso do poder que se tem, é por própria conta e risco. Por exemplo, caso se constitua livremente acima de si uma autoridade política, deve-se em seguida suportar todas as consequências disso, para si e para seus sucessores, pois o poder paterno é de direito positivo divino, e é possível vincular os filhos e descendentes. Toda a ordem social é outorga e distribuição de liberdades, estas essenciais à vida moral cristã do indivíduo. Enão há mais nada além disso. Os direitos subjetivos dos indivíduos preencheram o vazio resultante da perda do direito natural. A ordem social aparece agora constituída, não por uma rede de proporções entre os objetos partilhados entre as pessoas, mas por um sistema, por um lado, de poderes subordinados uns aos outros e, por outro, de leis provenientes dos poderes. (VILLEY, 2009, p. 286)

Se em tudo se acompanha Villey - a não ser na franca oposição ideológica - não há porque deixar de acompanha-lo em suas conclusões:

Não é o 'direito natural' que procede do cristianismo: ele vem de Aristóteles. É a filosofia
moderna, é o nominalismo, é o positivismo jurídico: daí o papel histórico essencial da
escolástica franciscana, que não escolhi por acaso, da qual, não sem razão, fiz objeto principal
de estudo. Pelo fato de essa filosofia ter-se apegado estritamente às fontes cristãs, pôde ser
uma das oficinas onde foram forjados os grandes conceitos jurídicos modernos. Ainda que
alguns dos germes do nominalismo possam ser encontrados em certos filósofos heterodoxos
da Antiguidade, sua plena eclosão, ligada ao nome de Guilherme de Ockham, é, a nosso ver,
solidária da mística do cristianismo, da ideia cristã do poder absoluto de Deus, da ideia cristã
da pessoa. E, em Guilherme de Ockham, já vimos o nominalismo engendrar o positivismo
jurídico e a ideia do direito subjetivo. É de fato com o nominalismo de Guilherme de
Ockham que se abrem oficialmente as portas da filosofia moderna.
[...] o nominalismo servirá de ponto de partida para as grandes filosofias do direito da era
moderna propriamente dita: Hobbes, Locke, Bentham etc. Será por intermédio dele que o
lugar central da ciência do direito será ocupado pela ideia de poder individual ou de direito
subjetivo, e por seu derivado, o de lei concebida como emanação do poder individual; que
toda outra fonte possível da ordem jurídica será rejeitada; que se virá a negar que, da
natureza, se possam extrair relações de direito. Embora o nominalismo ainda permita
conservar (como o farão Hobbes e Locke) uma lei natural moral, desembocará
necessariamente no positivismo jurídico que resume a doutrina de Hobbes e de sua
inumerável linhagem, à qual muito provavelmente ainda pertencemos.

Deus. Bem verdade é que esta noção soa absurda aos ouvidos da maior parte das pessoas que, em regra, não reflete acerca das razões pelas quais presta culto a Deus. No entanto, a definição de Suárez é intelectualmente compatível com a exclusão da noção de ordem, na qual o foco era a relação ontológica entre os entes (prestase culto a Deus

\footnotetext{
85 “[...], é raro os juristas cometerem o erro de se enfeudarem a uma única filosofia, a maioria dos teóricos jurídicos da época moderna praticou um compromisso entre o ockhamismo e o tomismo sempre vivo na educação oficial. Foram obrigados a atenuar as consequências inaceitáveis do nominalismo fazendo alguns empréstimos da doutrina do direito natural e, assim, realizaram, se não uma verdadeira síntese, pelo menos combinações ecléticas entre as duas filosofias: foi o que aconteceu com as doutrinas de Suárez, da escola do direito natural moderno, de Leibniz, de Wolff. Ao mesmo tempo, em sentido oposto, os filósofos nominalistas emprestaram de são Tomás o princípio da laicidade (pelo menos na ciência do direito) que levaram até o laicismo. Ora, mesmo às voltas com essas misturas entre os princípios oriundos de diferentes sistemas, continua sendo verdade que o pensamento jurídico moderno vive da herança que the legou a filosofia medieval. Assim, nosso contato com são Tomás e com os franciscanos ajudanos a
} 
porque ele é Deus) e sua substituição por um discurso de direitos (Deus reclama do homem o culto).

\title{
A IDEIA KANTIANA DE DEVER
}

Retornando ao estudo da relação entre Kant e Suárez, ainda, dois pontos do tratado deste último interessam a Agamben:

\begin{abstract}
O primeiro é aquele em que ele especifica a natureza legal do vínculo que une na religio o homem a Deus com o termo 'respeito' (reverentia, a mesma palavra com que Kant traduzirá, na Metafísica dos costumes, o termo alemão Achtung, que define o 'sentimento não empírico' que o homem prova diante da lei moral). [...] A religião é aquela virtude que se refere a Deus por meio de um dever que deriva não de uma norma, mas do respeito que a lei como tal - ou, antes, o legislador - inspira.

O segundo ponto é aquele em que Suárez define o dever religioso como um 'débito infinito'. À diferença dos outros deveres humanos, o débito que está em questão na religio não pode ser satisfeito de uma vez por todas, porque é inexaurível em sua essência: [...]

Na figura de uma virtude que não pode satisfazer completamente seu débito, faz sua primeira aparição na ética ocidental a ideia - tão cara aos modernos - de uma tarefa ou um dever infinito.

Como escreverá Kant quase dois séculos depois, 'a virtude é sempre progressiva, na medida em que com ela ocorra toda vez refazer-se do início. É sempre progressiva, porque, considerada objetivamente, é um ideal inatingivel, para a qual se tem, contudo, o dever de aproximar-se constantemente' ${ }^{\prime 86} 87888990$
\end{abstract}

compreender a passagem do direito clássico para o direito moderno, fenômeno que poderia ter certa importância na história do direito." in VILLEY. Michel. A Formação do Pensamento Jurídico Moderno. São Paulo: Editora Martins Fontes, 2009, p. 292.

86 "O respeito não coincide com a obediência, porque, enquanto o primeiro se refere à excelência da pessoa ('directe respicere personam excellentem'), a segunda concerne somente à norma concreta que emana dela ('personae excellentis praeceptum'). Se recorda-se que, para Suárez, o dever religioso tem caráter jurídico, tanto mais singular é a sutileza com que ele distingue o respeito (que é devido, por assim dizer, à lei como tal propter excellentiam, independentemente do conteúdo concreto das normas) da obediência, que se refere somente a determinado conteúdo normativo. [...] não pode acontecer, de fato, que a matéria e o débito da religião possam ser exauridos [exhauriri possit], porque é próprio dessa virtude que seu débito não possa nunca ser absolvido ou cumprido [impleri solutione], seja porque se trata de um débito de qualquer modo infinito [debitum quodammodo infinitum], seja porque ele cresce com sua própria satisfação, enquanto por meio deste o homem recebe um beneficio ulterior. Isso não ocorre na justiça com respeito aos homens, cujo débito pode ser extinto com a satisfação, de modo que não haja lugar para exibir posteriormente a justiça. Através dos atos da religião, ao contrário, o homem não pode jamais exaurir o débito que possui diante de Deus." in AGAMBEN, Giorgio, Opus Dei: Arqueologia do Oficio. São Paulo: Boitempo Editorial, 2013, p. 110.

${ }^{87}$ Segundo Agamben, ainda, "[N]a genealogia da ideia de dever, a carta de Samuel Pufendorf a Christian Thomasius de 17 de julho de 1688 ocupa um lugar particular. É nela que encontramos, de fato, afirmado pela primeira vez com clareza, ainda que ligeiramente, o princípio segundo o qual a categoria que deve guiar o tratamento da ética não é a virtude, mas o dever. Pufendorf escreve ao amigo: Aliás, considero um argumento forte para as pessoas razoáveis que não se deve organizar a moral segundo as onze virtudes de Aristóteles, a partir do momento em que posso demonstrar que elas são adequadas apenas a um certo gênero de república. E em geral [in universum] minha opinião é que não se deve organizar e tratar a moral segundo virtudes, mas segundo deveres [die Morale nicht secundum virtutes, sed secundum officia einrichten und tractiren soll]." in AGAMBEN, Giorgio, Opus Dei: Arqueologia do Ofício. São Paulo: Boitempo Editorial, 2013, p. 112.

${ }^{88}$ Continua Agamben: "Antes de tudo, a objeção contra as virtudes é articulada em dois momentos, um mais específico e outro geral (in universum). O primeiro se refere ao fato de que, como Pufendorf havia sugerido na carta imediatamente precedente de 19 de junho, Aristóteles, ao formular sua ética, tinha em mente na realidade as democracias gregas, que detinham o melhor gênero de república. A essa formulação restrita segue-se a afirmação mais

general, segundo a qual a ética não deve ser tratada segundo virtudes, mas sim deveres." in AGAMBEN, Giorgio, Opus Dei: Arqueologia do Ofício. São Paulo: Boitempo Editorial, 2013, p. 112. 
É sobre a Metafísica dos costumes (1797), última obra que Kant dedicou à moral, que Agamben se debruça agora.

No centro de seu tratamento, Kant põe o conceito de 'dever de virtude' ( Tugendpflicht), isto é, o conceito de 'um escopo que é ao mesmo tempo um dever'. Trata-se, identificando dever e virtude, de fazer coincidir a dimensão da ética com aquela de uma ação cujo único motivo e impulso (Treibfeder) é o dever. Mas isso é exatamente o que define o paradigma do ofício, em particular naquela sua figura extrema que é a religio, na qual, como vimos, a teoria das virtudes foi solidamente unida ao ofício litúrgico, abrindo caminho para o projeto, já claramente formulado em Pufendorf, de uma ética fundada sobre os deveres. Se toda a tradição teológica que examinamos, de Ambrósio a Suárez, tende em última análise a atingir uma zona de indiferença entre virtude e ofício, a ética kantiana, com seu 'dever de virtude', é a realização completa desse projeto. Aqui, porém, não se trata tanto de verificar as conexões genéticas imediatas (a ideia de um 'dever da virtude' - Pflicht der Tugend - já está explicitamente formulada em Crusius e Meier, e Kant não precisava extraíla novamente da teoria da religio em Suárez) nem de compreender que, se a ideia aberrante de uma ação realizada unicamente por dever (isto é, em obediência a um comando, e não por uma inclinação natural) pode penetrar e se impor na ética, foi somente porque a Igreja, através de uma praxe e uma teorização secular, havia elaborado o ofício como modelo da atividade humana mais alta, encarnada no ofício do sacerdote e, antes ainda, no sacerdócio de Cristo. Nesse sentido, o 'dever de virtude' não é outro senão a definição da vida devota que Kant havia assimilado através de sua educação pietista. (AGAMBEN, 2013a, p. 116)

Kant realiza então a plena indiferenciação, característica da modernidade, entre técnica, autoridade e

\footnotetext{
${ }^{89} \mathrm{Na}$ parte que vem a seguir, tomar-se-á de forma ainda mais direta a explanação de Agamben de sua tese. "Em 1673, Pufendorf publica o De officio hominis et civis [Sobre o dever do homem e do cidadão], no qual sintetizava, organizando em torno do conceito de officium, os resultados de sua obra-prima, o De iure naturae et gentium [Sobre o direito natural e direito dos povos] (1672) e, ao mesmo tempo, realiza o projeto depois enunciado na carta a Thomasius de uma ética articulada segundo deveres e não segundo virtudes. No livro de 1672, a esfera dos fenômenos ético-jurídicos foi definida como aquela dos entia moralia, isto é, com uma terminologia tomada por empréstimo justamente do ateu Espinosa, aqueles 'modos' que se aderem aos entes físicos 'para dirigir e temperar a liberdade das ações humanas voluntárias e para conferir à vida humana ordem e decoro'. E, assim como as substâncias físicas pressupõem um espaço em que consistam e se movam, aos entes morais corresponde um 'estado' (status) em que eles 'exerçam suas ações e seus efeitos'. A ação dos entes morais (em particular, das pessoas) na esfera do 'estado' é definida por sua imputativitas, isto é, pelo fato de que ela e seus efeitos possam e devam ser imputados aos agentes. A obrigação que nasce dessas ações não coincide com a coação externa, mas penetra na própria vontade do agente, como uma espécie de sentido moral intrínseco ('obligatio vero moraliter voluntatem afficiat et peculiari quasi sensu eandem intrinsece imbuat'), que o impele a conformar-se ao prescrito pelo norma. No De officio, 'dever' (officium) é o termo que designa a ação humana na medida em que se conforma à obrigação que nasce do prescrito pela lei natural ('officium [...] vocatur actio hominis, pro ratione obligationis ad praescriptum legis recte attemperata'). O princípio fundamental da lei de natureza, a que o officium deve conformar-se, é a socialitas, que se enuncia nestes termos: 'cada homem deve por quanto está em si cultivar e conservar a sociedade [cuilibet homini quantum in se colendam et servandam societatem]" in AGAMBEN, Giorgio, Opus Dei: Arqueologia do Ofício. São Paulo: Boitempo Editorial, 2013, p. 113.

${ }^{90} \mathrm{O}$ grande feito da obra de Pufendorf foi ter inserido o conceito de officium no jusnaturalismo. Hobbes já havia dito, no prefácio de sua obra De cive, que o objetivo de seu tratado era definir "os deveres [officia] dos homens, primeiro enquanto homens e depois enquanto cidadãos”. Strauss demonstrou já em uma recensão de 1933 e no livro de 1936 sobre a Ciência política de Hobbes, como Hobbes substitui a noção de dever pela de direito e como este dever/direito teria um só fundamento: o medo da morte violenta. Em Jean Domat, por sua vez, representa um momento na história do pensamento no qual, segundo Agamben, a articulação do direito em termos de dever já está completa. Quando, no início de seu tratado sobre direito público (1697), o grande jurista francês define com o termo devoir o fundamento da police générale d'un État [polícia geral de um Estado], o que ele denomina com esse termo não é outro, porém, que o officium do qual procuramos reconstruir a genealogia." Em Domat, diz Agamben, ainda, o termo devoir [dever] é estreitamente conexo em Domat com o de conduite [conduta]: a vida e a ação dos homens na sociedade é sempre "conduzida", isto é, objeto de um guia e de um governo. Essa nota contém informações extraídas de AGAMBEN, Giorgio, Opus Dei: Arqueologia do Ofício. São Paulo: Boitempo Editorial, 2013, p. 115 e ss..
} 
vontade. À sombra da noção de indiferenciação entre dever e virtude, cresceu esta hidra, a partir da superprojeção dada ao sacerdote enquanto instrumento de Cristo e à técnica enquanto conferidora de um sentido às coisas, de forma que, quando se viu, a autoridade do sacerdote virou uma autoridade anárquica (incompatível com o conceito original de autoridade, o auctoritas romano) e a técnica virou o fim, o sentido da ação. No recanto mais escuro desta sombra, a vontade, enquanto ontologia do ser na modernidade, assumiu primazia absoluta e afastou qualquer justificação metafísica para o homem e suas ações. Mesmo a lei não era obedecida pela sua virtude (ou desobedecida pelos seus vícios, afinal era mala quia prohibita e não o contrário), mas pelo dever de se obedecêla. ${ }^{91}$

Ademais, "a constrição que está em questão na lei moral não é, como no direito, uma força externa, mas uma autoconstrição (Selbstzwang), que deve superar a resistência das inclinações naturais”, Kant cria, portanto, um meio de tornar intelectualmente apreensível conceitualmente "a autoconstrição do dever moral. Esse dispositivo é o 'respeito' (Achtung, reverentia), ou seja, o próprio vínculo que, segundo Suárez, une imediatamente na religio o homem a Deus." (AGAMBEN, 2013a, p. 117) ${ }^{92}$ Segundo Agamben:

O respeito é, assim, o sentimento - puramente negativo e em si privado de todo prazer - da sujeição a um comando: 'Ele, então, como sujeição a uma lei, isto é, como comando (que significa violência para um sujeito afeito sensivelmente) não contém nenhum prazer, mas antes, nesse sentido, desprazer pela ação em sí. O respeito é, assim, o grau zero do sentimento, ou aquele sentimento (ou aquele desprazer) que resta quando todas as inclinações naturais e todos os sentimentos 'patológicos' (isto é, passivos) foram excluídos como motivos da ação.

Nesse ponto, Kant pode coligar respeito (Achtung) e dever (Pflicht). A ação realizada unicamente por respeito à lei chamase, assim, 'dever ${ }^{23} 94$

Agamben, então, caminha para a inexorável conclusão:

O que em Kant atinge a realização na forma do dever-ser é a ontologia da operatividade,

\footnotetext{
91 "Se no ofício a garantia da efetualidade da ação litúrgica ex opere operato está em Cristo, o que em Kant toma o lugar de Cristo como garantia da efetualidade do dever é a lei. Na Fundamentação da metafísica dos costumes, o dever se define, de fato, como 'a necessidade de agir por puro respeito à lei'. O nexo essencial entre dever e lei é constantemente confirmado por Kant: 'O conceito de dever é imediatamente ligado a uma lei'; isso se resolve, portanto, em 'uma obrigação [Nöthigung] ou constrição [Zwang] exercida pela lei sobre o livre arbítrio'." in AGAMBEN, Giorgio, Opus Dei: Arqueologia do Ofício. São Paulo: Boitempo Editorial, 2013, p. 117.

92 "Como a reverentia em Suárez, que não é devida a uma norma concreta (praeceptum personae excellentis), mas à excelência da pessoa como tal (persona excellens), o respeito não se refere a um comando específico, mas à lei em geral, a conformidade à qual deve se tornar o único motivo da ação: 'Se se desnuda a vontade de todos os impulsos que possam vir do que segue à observância da lei, não resta senão a conformidade da ação à lei em geral [...] ou seja, devo comportar-me de modo a poder também querer que minha máxima se torne uma lei universal” in AGAMBEN, Giorgio, Opus Dei: Arqueologia do Ofício. São Paulo: Boitempo Editorial, 2013, p. 118

${ }^{93}$ E ainda: "A consciência de uma sujeição livre da vontade à lei, ligada, todavia, a uma coerção inevitável que é afeita a todas as inclinações, mas só mediante a própria razão, é o respeito da lei [...]. A ação que, segundo essa lei, com exclusão de todos os motivos determinantes, é objetivamente prática, chama-se dever; o qual, por essa exclusão, contém em seu conceito um constrangimento prático, isto é, uma determinação das ações, ainda quanto mal volentieri ele traga." in AGAMBEN, Giorgio, Opus Dei: Arqueologia do Ofício. São Paulo: Boitempo Editorial, 2013, p. 120.

${ }^{94}$ Em Kant, portanto, "[A] estrutura do imperativo e do dever citada na definição - a constrição do livre querer através de uma lei resta, todavia, a mesma, independentemente do fato de que provenha de fora (constrição jurídica) ou de dentro (constrição ética).” in AGAMBEN, Giorgio, Opus Dei: Arqueologia do Ofício. São Paulo: Boitempo Editorial, 2013, p. 119.
} 
cujas linhas fundamentais buscamos reconstruir. Nesta, como vimos, ser e agir indeterminam-se e contraem-se um no outro e o ser torna-se algo que não é simplesmente, mas dever ser atuado. Não é possível, no entanto, entender a natureza e as características próprias da ontologia da operatividade, se não se compreende que esta é, desde o início e na mesma medida, uma ontologia do comando. A contração de ser e dever-ser tem a forma de um comando, é essencialmente e literalmente um 'imperativo'. O dever-ser não é, nesse sentido, um conceito jurídico ou religioso que se alcança de fora do ser: ele implica e define uma ontologia, que se afirma progressivamente e se põe historicamente como a ontologia da modernidade. (AGAMBEN, 2013a, p. 122)

Assim:

Se a ontologia na tradição da filosofia clássica tem caráter substancial, no sentido que o ser implica um denotativo entre as palavras e as coisas, o imperativo, como forma primitiva do verbo, pressupõe uma outra ontologia, que pretende referir-se não ao mundo 'como é', mas como 'deve ser'. (AGAMBEN, 2013a, p. 123)

Diz ainda Agamben que:

Há, portanto, na tradição ocidental, duas ontologias, distintas e coligadas: a primeira, a ontologia do comando, própria do âmbito jurídico-religioso, que se exprime no imperativo e tem caráter performativo; a segunda, própria da tradição filosófico-científica, que se exprime na forma do indicativo (ou, em forma substantivada, no infinitivo ou no particípio - esti, einai, on, 'é, 'ser', 'ente'). A ontologia do estōe do 'seja' remete a um deverser; aquela do estie do 'é' se refere ao ser. Claramente distintas e, por muitos aspectos, opostas, as duas ontologias convivem, confrontam-se e, de qualquer modo, não cessam de entrelaçar-se, hibridizar-se e prevalecer, de vez em vez, uma sobre a outra na história do Ocidente.

É, no entanto, na análise que vem logo a seguir que Agamben desvenda a questão kantiana. Segundo ele,

Kant representaria o momento máximo de elaboração da ontologia do comando e do dever-ser, penetrando na ontologia da substância e do ser, transformando-a pelo seu interior. ${ }^{95}$

No limiar da modernidade, quando a teologia e a metafísica parecem ceder definitivamente o campo para a racionalidade científica, o pensamento de Kant representa o ressurgimento secularizado da ontologia do estō no seio da ontologia do esti, o ressurgir catastrófico do direito e da religião no seio da filosofia. Diante do triunfo da consciência científica, Kant procurou assegurar a sobrevivência da metafísica, enxertando e deixando agir a ontologia do comando e do dever-ser naquela do ser e da substância. Crendo assegurar desse modo a possibilidade da metafísica e fundar, ao mesmo tempo, uma ética não jurídica nem religiosa, ele, por um lado, acolheu sem dar-se conta a hereditariedade da tradição teológico-litúrgica

\footnotetext{
95 "Se isso é evidente no que diz respeito à ética, menos óbvio é que também a Crítica da razão pura possa ser lida nessa perspectiva. A possibilidade da metafísica coincide aqui com o uso da razão 'pura', isto é, sem referência ao ente e à experiência. A substituição do 'nome glorioso de ontologia' por aquele de 'filosofia transcendental' significa, justamente, que uma ontologia do dever-ser já tomou o lugar da ontologia do ser. O objeto transcendental e o númeno não designam, portanto, um ente, mas um x, 'do qual não sabemos nada, nem em geral [...] podemos saber nada'. Eles são não seres, mas exigências, não substâncias, mas imperativos, a que nada pode corresponder no plano da experiência. Do mesmo modo, as ideias da razão são ideias 'reguladoras', 'comandos', e não palavras denotativas. O dever-ser corresponde, assim, na ética kantiana, à função que o númeno e a coisa em si desempenham na metafísica: assim como estes impõem ao pensamento a abertura de um espaço, que, no entanto, deve permanecer vazio, o imperativo categórico comanda a razão prática de modo determinante e, todavia, não diz nada (não surpreende, nessa perspectiva, que Schopenhauer tenha podido identificar a dimensão da vontade com a da coisa em si e intitular um dos suplementos a sua obra principal de Considerações transcendentes sobre a vontade como coisa em si)." in AGAMBEN, Giorgio, Opus Dei: Arqueologia do Ofício. São Paulo: Boitempo Editorial, 2013, p. 125.
} 
do officium e da operatividade e, por outro, demitiu permanentemente a ontologia clássica. ${ }^{96}$

O fato de "[Q]ue a ontologia kantiana seja, na verdade, uma ontologia do comando alcança em Kelsen sua máxima evidência. Ele parte de uma absolutização sem reservas de Sein e Sollen, ser e dever-ser, assumida incondicionalmente como um postulado dualista”. Continua o autor:

\begin{abstract}
A teoria pura do direito pressupõe, assim, duas ontologias, irredutíveis uma a outra e, como Kant, escolhe como âmbito próprio a do comando e do dever-ser. Ela é 'pura', porque pretende manter-se constantemente na esfera do Sollen, sem jamais transpassar para aquela do Sein. O dever jurídico não coincide, de fato, com um ser ou com um estado de coisas, isto é, com um comportamento devido, mas exprime somente o fato de que um certo comportamento é estabelecido por uma norma, e que essa norma remete a outra norma (a sanção coercitiva) e esta ainda a outra [...] (AGAMBEN, 2013a, p. 127) $)^{97} 98$
\end{abstract}

\title{
PROTESTANTISMO E PROVIDENCIALISMO NA COMPOSIÇÃO DA PAISAGEM MORAL KANTIANA (WEBER - AGAMBEN)
}

O estoicismo ciceroniano, que foi o ponto de partida desta grande digressão, acabou por penetrar no

\begin{abstract}
${ }^{96}$ Ainda: "A 'revolução copernicana' operada por Kant não consiste tanto no ter posto o sujeito no centro, em vez do objeto, mas antes - e as duas prestações são, na verdade, inseparáveis - no ter substituído por uma ontologia do comando a ontologia da substância [...]” in AGAMBEN, Giorgio, Opus Dei: Arqueologia do Ofício. São Paulo: Boitempo Editorial, 2013, p. 125.

${ }^{97}$ Agamben rememora: "Durante o processo de Jerusalém, Eichmann declarou a certa altura 'ter vivido toda a sua vida segundo os preceitos da moral kantiana, em particular de acordo com a ideia kantiana de dever'. Instado a precisar o que pretendia dizer, ele acrescenta, mostrando assim ter efetivamente lido a Crítica da razão prática: 'Quando falei de Kant, pretendia dizer que o princípio da minha vontade deve ser sempre tal a poder se tornar o princípio de leis universais'. [...] Boa parte da assustadora precisão com que foi implementada a solução final [...] se pode justamente reconduzir à estranha ideia, de fato muito difundida na Alemanha, de que ser leal à lei não significa simplesmente obedecer, mas também agir como se fosse o legislador que escreveu a lei a que se obedece. Seja qual for o papel que Kant tenha tido na formação da mentalidade da 'pobre gente' na Alemanha, não há a mínima dúvida de que em uma coisa Eichmann segue realmente os preceitos kantianos: uma lei é uma lei e não pode haver exceções a ela. A cegueira de Kant é não ter visto que, na sociedade que estava nascendo com a Revolução Industrial, na qual os homens seriam sujeitados a forças que não poderiam de modo nenhum controlar, a moral do dever os havia habituado a considerar a obediência a um comando (pouco importa se externo ou interno, porque nada é mais fácil que interiorizar um comando externo) como um ato de liberdade.” in AGAMBEN, Giorgio, Opus Dei: Arqueologia do Ofício. São Paulo: Boitempo Editorial, 2013, p. 126.

${ }^{98}$ Este largo trecho que aqui se colacionou é a justificativa de haver esta seção na presente monografia. Agamben caminha então para sua conclusão examinando uma suposta patologia do kantismo, não escondendo sua repulsa por esta doutrina: "Em 1963, Jacques Lacan, em um célebre ensaio, propunha uma leitura paralela de Kant e Sade na qual o objeto da lei e o objeto do desejo reprimido eram identificados. Podemos nos perguntar se, como Gilles Deleuze sugeriria cinco anos depois, a subversão da lei kantiana já não teria sido realizada por Sacher-Masoch de maneira mais eficaz que por Sade. O virtuoso kantiano e o masoquista coincidem, de fato, precisamente naquilo que ambos encontram seu elemento próprio unicamente no dever e na humilhação, ou seja, na execução de um comando. Nesse sentido, a ética kantiana - e, com ela, grande parte da ética moderna - é essencialmente masoquista. À primeira vista, no entanto, o masoquista difere do virtuoso kantiano, porque, enquanto para este o comando não contém nenhum prazer, aquele encontra seu prazer na humilhação. Não basta dizer, contudo, que o masoquista sente prazer no ser humilhado pelo comando da lei; cumpre acrescentar que o masoquista sente prazer no fato de que a lei sente prazer em humilhálo. O masoquista, de fato, não sente prazer na dor e na humilhação, mas no provocar ao sádico um prazer, que consiste no infligir dor e humilhação. O masoquista - nisto consiste a sutileza de sua estratégia - faz gozar a lei (personificada pelo sádico) e só desse modo alcança o prazer. A lei é mantida e seu comando é seguido com zelo, mas ela não possui em si nada de respeitável, porque seu comando contém o prazer. Enquanto a operação do homem de Sade se volta, assim, imediatamente contra a lei como tal, a do masoquista é voltada contra o respeito, que mina sua base e a destrói. Vitória efêmera, todavia, porque, como mostram eficazmente as modernas massas masoquistas, que não respeitam o líder que aclamam, elas não podem certamente dizer-se mais livres por isso.
\end{abstract}


caldeirão de influências diversas que geraram o renascimento humanista em idos do séc. XVI, que transformaram o homem do medievo, um beneficiário da Ordem, que conceitualmente abrangia Direitos e Deveres compreendidos relacionalmente, ou seja, não como meros Deveres e Direitos exequíveis, a partir da posição do homem na sociedade, no homem "moderno", titular autônomo de Direitos individuais e Deveres comunitários. Como visto, apesar de aspectos de continuidade, o Estado Moderno gera uma ruptura em relação às máquinas de disposição de poder fundadas na autoridade através do esvaziamento do mecanismo de legitimação de Direitos, que passam a depender somente da vontade política do soberano. É neste momento que se expande a formação universitária em Direito, porquanto os soberanos passam a buscar administradores versados no discurso da autoridade, representado perfeitamente no Direito Romano, grande objeto de estudo das faculdades de Direito.

No entanto, ainda que em fase de racionalização, ou melhor laicização, os Deveres eram ainda tratados como um fenômeno eminentemente religioso-moral, porquanto submetidos às autoridades religiosas, como corolários de um Ordenamento que, ainda que formalmente jurídico e administrativamente estatal, era materialmente religioso.

Foi no ideário calvinista, segundo Nabais, que houve a primeira transição clara formal dos Deveres do campo religioso-moral para o jurídico-estatal, com a conversão das Leis Morais judaicas (leis mosaicas), presentes no Antigo Testamento, que nos espaços católicos e luteranos não tinham status de lei, enquanto normas de direito divino positivo, em normas jurídicas sancionatórias, "assim dando suporte às obrigações de trabalhar, de respeitar com lealdade o pactuado, de não afectar a propriedade alheia, etc" (NABAIS, 1998, p. 42). Isso foi uma grande novidade no período, porquanto na contramão da filosofia escolástica tomista, doutrina oficial da Igreja, que considerava a lei mosaica restrita à moral, sem coercibilidade no mundo político cristão.

Vale desde já, adiantando certos materiais que serão tratados mais a frente, analisar aspectos jurídicos de relação do indivíduo com a autoridade presentes nas doutrinas reformistas de Lutero e Calvino e que foram aspecto fundamental na formação de Kant e, portanto, da ideologia jurídica moderna e contemporânea. Novamente, sob pena de se perder muito tempo na explicação de temas que não são o objeto deste trabalho propriamente dito, mas que são fundamentais para uma plena compreensão deste, apelarse-á à obra de Michel Villey.

Segundo Villey, há "três consequências da reflexão religiosa na obra de Lutero:

uma depreciação do direito (é a chave do resto); o abandono do antigo direito natural clássico; a substituição dessa antiga filosofia por uma forma particularmente rígida de positivismo jurídico." (VILLEY, 2009, p. 309) Interessa, para a tese aqui desenvolvida, a terceira consequência, mais que as outras, vez eu este positivismo, como já visto, se identifica em sua matriz com a matriz kantiana do positivismo normativista kelseniano.

A queda do chefe, que lhes descerra a possibilidade do vilipêndio, é também a sanção de sua servidão." in AGAMBEN, Giorgio, Opus Dei: Arqueologia do Ofício. São Paulo: Boitempo Editorial, 2013, p. 121. 
A título de introdução, vale lembrar que Lutero ensina, diferentemente de - admitindo o risco de ser temerário - todos os teólogos católicos com alguma doutrina jurídica imanente de sua filosofia, que a obediência à Lei não tem qualquer alcance religioso, não tendo, consequentemente, qualquer papel na economia da salvação.99

Lutero ensina, ainda, em consonância com a doutrina de Paulo, "que o cristão está isento da obediência a qualquer lei - a não ser que se trate da 'lei de Cristo". Mas essa liberdade. por sua vez, só funciona na esfera religiosa. ${ }^{100}$

Esta afirmação indica a clara mudança de significado da palavra direito no entendimento de Lutero em relação ao entendimento da jusfilosofia cristã que o precedeu e que se alinha a uma tradição mais vinculada a filosofia aristotélico-tomista. Nestes o direito é uma regra de divisão de bens, veículo fundamental da concepção de justo. A partir do nominalismo já se começa a pensar o direito como algo que seja pessoal, direito subjetivo, que se possa reivindicar, enquanto que a organização comunitária, a comunidade partilhada em duas, a dos santos e a dos homens, mas unidas, para que se refira a tão influente divisão agostiniana, se dará segundo a justiça, na comunidade dos santos (Lutero os chama simplesmente cristãos), que se realiza voltada para o fim do homem, o ritual de adoração divina na forma da lei de Cristo, ou segundo a autoridade, na dos homens, que tem como fim a coerção dos atentados contra a ordem, que é a ela intrínseca e que tem seu conteúdo previsto na Sagrada Escritura.

Embora ambas as posições pareçam se assemelhar, é importante atentar que o cristão, o santo, como já dito, não está submetido ao direito, à Lei (e aqui só se quer dizer Direito estatal, ou, mais propriamente, da autoridade). A única lei que obriga o cristão é "lei de Cristo, [...] informulada, informulável”. Assim se pode explicar a proliferação de seitas de caráter secessionista em relação à Roma ou a qualquer outra Igreja com pretensão universal surgidas na Europa no período, e mesmo antes. Estas seitas tinham como fundamento de sua própria

\footnotetext{
${ }^{99}$ VILLEY. Michel. A Formação do Pensamento Jurídico Moderno. São Paulo: Editora Martins Fontes, 2009, p. 311. Na mesma página, porém, Villey relembra que "entre as obras morais, destacavam-se as obras de justiça - entenda-se: daquela virtude moral, tal como fora concebida pelos pagãos, e que a Suma de são Tomás se propusera a restaurar, aquela que tem por objetivo dar a cada um o que lhe corresponde. Lutero não atribui a ela mais valor, tendo em vista a salvação, que ao resto da moral; chega até a negar-lhe o nome de justiça, para reservar esse rótulo à Justiça segundo a Bíblia e segundo são Paulo, aquela que só se adquire pela fé. Abraão acreditou e isso lhe foi creditado na conta de justiça. 'Pois a palavra justiça pode ser entendida em muitos sentidos; há uma justiça política, [...] uma justiça cerimonial, [...] e uma que chamam de legal [...]; mas, acima de tudo isso, há a justiça da fé que é a justiça cristâ.".

100 “[...] mas esta é informulada, informulável, completamente interior, subjetiva, e seu único conteúdo é a fé. Quanto a todas as outras leis, o cristão é profundamente livre. Lutero libertou-o dos vínculos do direito canônico, como também da lei moral. Tornouo senhor de si (pelo menos na esfera da vida religiosa); alçou ao pináculo sua liberdade, poderíamos dizer (adiantando-nos um pouco) que, em potência, descobriu a Innerlichkeit, cara ao pensamento germânico, e a competência normativa da livre subjetividade. Nisso, Lutero é moderno; poderíamos relacionar sua posição com as de Montaigne ou de Descartes que, à maneira deles, bem diferentes uma da outra, tendem a fundar no seu eu sua moral, no caso de Montaigne, sua filosofia, no caso de Descartes. [...] É do ponto de vista da salvação (que, aliás, só vale para um monge) que o cristão é totalmente livre em relação a qualquer lei, e a qualquer regra de direito. Na vida cristã perfeita, nem mesmo existe direito. 'Se o mundo todo fosse constituído de verdadeiros cristãos, não haveria nem necessidade nem utilidade [...] de príncipe, rei, senhor ou gládio - e tampouco de direito." in VILLEY. Michel. A Formação do Pensamento Jurídico Moderno. São Paulo: Editora Martins Fontes, 2009, p. 311.
} 
ordem comunitária o conceito de Justiça cristã e a conviç̧ão transcendental de que esta Justiça estabelecia à ordem através da ação livre de seus membros em comunidade, inspirada em regras bíblicas. A violação frontal a esta ordem afetava à comunidade não no sentido de demandar a reposição do subtraído, fosse uma vida ou um bem, mas no sentido de demandar a expulsão da comunidade, expulsão esta que por vezes tinha caráter meramente declaratório, vez que, nesta forma de viver o Evangelho, o comportamento transgressor era prova da ausência de Graça Divina (a ausência da retidão de vontade a qual santo Agostinho se refere e que é o significado de Justiça no pensamento ockhamiano), o que significava que a pessoa não era mais uma cristã, ou seja, que ela não pertencia mais à comunidade. Esta forma de comunidade cristã decorre da radicalização da Reforma, e é genericamente representada pelos movimentos anabatistas, mas também encontra grandes expressões políticoteológicas no pensamento calvinista. ${ }^{101} \mathrm{O}$ pensamento luterano, ainda que reforçando as bases do pensamento de Escoto, ${ }^{102}$ ainda via a natureza desgraçada do homem como absolutamente comum e a ação de graça (ou seja, as boas obras, a virtude, subtraído o seu caráter voluntário, humano) como um milagre ocasional e sem efeitos permanentes.

Weber reforça este sentido, ao afirmar:

a Reforma significou não tanto a eliminação da dominação eclesíatica sobre a vida de modo geral, quanto a substituição de sua forma vigente por uma outra. E substituição de uma dominação extremamente cômoda, que na época mal se fazia sentir na prática, quase só formal muitas vezes, por uma regulamentação levada a sério e infinitamente incômoda da conduta de vida como um todo, que penetrava todas as esferas da vida doméstica e pública até os limites do concebível. (WEBER, 2007, p. 30)

Esta forma de dominação, que não é jurídica, mas do Beruf, é que torna a Reforma palco de conflito, resolução e geração de tensões psicológicas que vão permear a modernidade, e que se traduzem em conflitos

\footnotetext{
${ }^{101}$ Tomando como exemplo para esta afirmação a experiência da imigração puritana e fundação de comunidades religiosamente inspiradas na Nova Inglaterra - da qual o maior exemplo de instrumento de agregação comunal identitária é o sermão do líder puritano John Winthrop "A Model of Christian Charity", proferido em 1630, e que traz em si o conceito de "City Upon a Hill", retirado de Mateus 5:14 - tido por muitos como um dos grandes exemplos da crença no excepcionalismo norte-americano. Esta interpretação, no entanto, parece profundamente voltada para uma concepção nacionalista de história. John Winthrop certamente não imaginava estar fundando, com seu discurso, a ideologia política que estruturaria os Estados Unidos da América. Ele apenas fazia parte de um grupo perseguido que queria levar uma vida segundo seus valores comunitariamente estabelecidos em paz. Serão estas comunidades tratadas especificamente mais à frente.

${ }^{102}$ No qual o Amor a Deus era o único princípio de toda a moral e, consequentemente, de toda a Justiça. Neste sentido: "Duns Escoto é também chamado de o filósofo do amor; para ele não existe nenhum valor moral além do amor - e não o amor egoísta que busca seu próprio aperfeiçoamento, a realização de sua natureza, mas o amor cristão, a ágape, o 'amor amicitiae', que se volta gratuitamente para o outro, que se dá gratuitamente ao outro, que só quer o bem do outro. A inteligência só desempenha aí um papel auxiliar; ela pode julgar sobre a 'conveniência' de tal ou qual ato ao preceito soberano do amor (se amo a música, convém fazer escalas...). Quanto à satisfação das inclinações naturais, à realização por cada um de sua 'natureza própria', ela apenas pertence, segundo Duns Escoto, à esfera do 'commodum', sem relação com a moral. Amor a Deus, único princípio de toda a moral. E o segundo preceito - o de amor ao próximo - é idêntico ao primeiro. Pois Deus quis ser amado junto com todos os homens feitos à sua imagem, numa associação de amor ('vult alios condiligentes'). Assim, encontramos sempre o Evangelho. Mas a moral do Evangelho está agora harmonizada com uma nova filosofia, filosofia do indivíduo: é também a independência, a liberdade do indivíduo que Duns Escoto obstina-se em salvar, quando a ditadura da Razão objetiva for eliminada - o ato individual depende
} 
militares que, em si, já são responsáveis tanto por uma filosofia que foge do autoritarismo, seja através do conflito com ele (como em Locke) ou através da racionalização absoluta das relações entre Estado e indivíduo (Kant), quanto por uma que vai em sua direção, como a de Hobbes e a de Lutero.

Mas o que seria esta forma de dominação do Beruf? Diz Weber que, na Antiguidade e nos povos predominantemente católicos a palavra não é comum. Só o hebraico, das línguas antigas, teria expressão semelhante, utilizada para definir qualquer trabalho profissional, desde as funções sacerdotais aos desempenhados por um escravo.

A palavra utilizada, mela'khah, "deriva da raiz l'kh = enviar, mandar em missão, e portanto significa originalmente "missão" e teria, portanto, relação conceitual com as "burocracias litúrgicas do Estado egípcio assentado na corveia e do Estado salomônico nele inspirado" (WEBER, 2007, p. 185), sentido que haveria se perdido já na própria Antiguidade. No Eclesiástico 11:20-21, ${ }^{103}$ no entanto, ela é utilizada para designar o cumprimento dos mandamentos de Deus, e é exatamente aí que Lutero utiliza pela primeira vez a palavra, ainda que acidentalmente. ${ }^{104}$ Em latim, Sêneca teria sido o primeiro a traduzir a ideia de Berufe, officium (e aqui se constata a existência uma interessante zona de indeterminação causada por Weber, vez que o estudo do dever não tem a ver com o estudo do Beruf em si - dever é Pflicht em alemão, e Beruf - "a atividade especializada e duradoura de uma pessoa, a qual (normalmente) é para ela também fonte de renda e portanto base econômica durável de sua existência", mas com "conteúdo ético" - WEBER, 2007, p. 186 - simplesmente não teria termo próprio em latim) ${ }^{105}$ é a palavra que Weber escolhe para imputar esta responsabilidade, além de munus, que também já apareceu aqui, "que deriva de uma expressão para as corveias das antigas comunas urbanas". Ou ainda:

[...] finalmente professio, palavra mais caracteristicamente derivada, nessa acepção, dos deveres de direito público, notadamente das antigas declarações de impostos dos cidadãos, e mais tarde empregada especialmente para as 'profissões liberais' no sentido moderno do termo [...]; professio assume, estritamente nesse campo, um significado em todos os aspectos bastante análogo ao nosso termo Beruf (inclusive no sentido mais interior do termo, como quando Cícero diz de alguém: non intelligit quid profiteatur, querendo dizer 'ele não conhece sua verdadeira vocação'), só que esta é pensada, é claro, em termos definitivamente intramundanos, sem nenhuma conotação religiosa ${ }^{106}$

A questão com o termo Beruf neste sentido é que ele é de fato uma criação do Lutero, apesar de Weber afirmar que São Jerônimo, quando da confecção da Vulgata, se utilizando da palavra locus mandatorum tuorum, no mesmo trecho em questão, já teria tensionado uma conotação religiosa, ainda que extramundana, ao falar de

apenas da escolha supra-racional, da escolha pessoal do amor." In VILLEY, Michel. A Formação do Pensamento Jurídico Moderno. São Paulo: Editora Martins Fontes, 2009. P. 207.

${ }^{103} \mathrm{Na}$ Bíblia de Jerusalém: "Permanece firme na tua tarefa, ocupa-te bem dela/ e envelhece na tua profissão/ Não te espantes com as obras do pecador/ mas confia no Senhor e permanece no teu trabalho”.

${ }^{104}$ Por isso que a tradução "dever profissional" se mostra inadequada.

${ }^{105} \mathrm{O}$ que se constata, no entanto, é a variedade de termos existentes na língua alemã relacionadas ao conceito de Dever. 
posição social, mas a posição social de alguém devotado à ascese - a profissão, na verdade, enquanto trabalho para a salvação, sentido que parece ter se perdido na tradução citada da Bíblia para o português, esvaziada a locução de qualquer sentido extramundano. As Bíblias anteriores ao Lutero, traduzidas para o alemão, davam esta mesma conotação intramundana sem qualquer relação com a ética, ao utilizarem a palavra Werk. Weber afirma que o termo Berufé, inclusive, inadequado para traduzir a ideia contida no texto original, da qual não se desprenderia qualquer sentido extramundano, mas é a intenção de associar ideias presentes em outras partes da Bíblia (como a ideia de chamamento à pregação por Deus/ do Evangelho/ à Salvação) que prevalece. ${ }^{107}$ Depois, no entanto, todas as confissões protestantes, que já tinham traduzido o termo diferente, foram lentamente adotando a terminologia de Lutero (um místico alemão, Tauler, diz Weber, a teria usado antes de Lutero).

Em suma:

\begin{abstract}
assim como o significado da palavra, assim também [...] a ideia é nova, e é um produto da Reforma. Não que certos traços dessa valorização das atividades no mundo, inerente a esse conceito de Beruf, não estivessem presentes já na Idade Média ou mesmo na Antiguidade (helenística tardia) [...] Uma coisa antes de mais nada era absolutamente nova: a valorização do cumprimento do dever no seio das atividades mundanas como o mais excelso conteúdo que a autorrealização moral é capaz de assumir. Isso teve por consequência inevitável a representação de uma significação religiosa da atividade mundana de todo dia e conferiu pela primeira vez ao conceito de Beruf esse sentido. No conceito de Beruf, portanto, ganha expressão aquele dogma central de todas as denominações protestantes que condena a distinção católica dos imperativos morais em "praecepta" e "consilia" e reconhece que o único meio de viver que agrada a Deus não está em suplantar a moralidade intramundana pela ascese monástica, mas sim, exclusivamente, em cumprir com os deveres intramundanos, tal como decorrem da posição do indivíduo na vida, a qual por isso mesmo se torna a sua "vocação". 108
\end{abstract}

\footnotetext{
${ }^{106}$ WEBER, Max. A ética protestante e o "espírito" do capitalismo. São Paulo: Editora Schwarcz Ltda., 2007, p. 186. Em latim, provou-se, há uma distinção que poderia ser feita entre professio, officium e Beruf. Também, professio aqui retoma, em outra chave, a discussão acerca do trabalho na modernidade, já tratada aqui.

${ }^{107}$ Como o próprio Weber afirma "em 1530 a Confissão de Augsburgo define o dogma protestante da inutilidade de suplantar, à maneira católica, a moralidade intramundana e, nisso, emprega a expressão 'einem jeglichen nach seinem Beruf \{a cada qual segundo sua profissão' \} (ver a nota anterior). Aqui na tradução de Lutero desponta esse fato, ocorrido precisamente no início dos anos 1530, junto com o crescente apreço pela santidade da ordem na qual está inserido o indivíduo, apreço resultante de sua crença cada vez mais nítida numa Providência divina todo especial a intervir nos mínimos detalhes da vida, ao mesmo tempo que se projeta sua crescente tendência a uma aceitação da ordem do mundo imutável, como a quer Deus. [Foi sob a pressão desse dogma que o termo vocatio, que no latim tradicional era empregado especialmente para o chamado divino à vida religiosa dentro do mosteiro ou como clérigo, assumiu para Lutero essa conotação de trabalho profissional dentro do mundo como 'vocação.]" in WEBER, Max. A ética protestante e o "espírito" do capitalismo. São Paulo: Editora Schwarcz Ltda., 2007, p. 191. Colaciona-se uma parte da nota anterior aqui vez que ela proporciona reflexões interessantes sobre o tema deste trabalho: "Em contrapartida, a Confissão de Augsburgo contém esse conceito, apenas parcialmente desenvolvido e implíito. Se no artigo 26 (ver a edição de Kolde, p. 43) está dito: 'De fato, o Evangelho (...) não condena o governo mundano, a polícia e o matrimônio, mas quer que tudo isso seja tomado como ordem de Deus e que nesses estamentos se pratique a caridade cristã e as boas obras segundo sua vocação' (em latim está dito apenas: et in talibus ordinationibus exercere caritatem, ibid., p. 42), então a consequência que se tira, a saber: que se deve obedecer à autoridade - mostra que aqui, ao menos em primeiro lugar, Beruf vem pensado como uma ordem objetiva, no sentido da passagem de 1Cor 7, 20." in WEBER, Max. A ética protestante e o "espírito" do capitalismo. São Paulo: Editora Schwarcz Ltda. 2007, p. 188.

${ }^{108}$ WEBER, Max. A ética protestante e o "espírito" do capitalismo. São Paulo: Editora Schwarcz Ltda., 2007, p. 72. Vê-se a dificuldade de tradução do termo português pela utilização constante de terminologia vinculada a profissional, profissão etc.
} 
Ou seja, ser um trabalhador perfeitamente submisso.

Nos primeiros anos de Reforma, a atividade que era desempenhada pelo Beruf não importava tanto, era mera questão de atender ao previsto no capítulo 7o, v. 20-24, da $1^{\text {a }}$ Carta de Paulo aos Coríntios, ou seja, manter-se cada um em sua condição e esperar pelo Retorno de Cristo (uma atitude de indiferença). No entanto, Weber afirma, conforme Lutero se dedicou mais às tarefas do mundo, mas o Beruf seguido the pareceu ser instrumento da Providência e, durante as guerras contra os camponeses e contra os anabatistas, esta crença se fortaleceu a ponto de assumir um caráter absolutamente rígido, ou seja, a atividade exercida não poderia ser abandonada, tampouco se deveria desejar abandoná-la, vez que esta entrega seria representativa da submissão absoluta do homem à vontade de Deus. Nestes primeiros anos de pregação, os únicos resultados práticos atingidos foram a submissão dos fiéis a uma prática mecanicista das atividades mundanas como flâmulo da submissão a Deus, sem a ascese de uma vida especialmente espiritualizada (afinal, as atividades mundanas eram em si uma forma de prática religiosa) e a submissão à autoridade. Havia, em suma, uma grande conformação deliberada com o status quo. Esta forma de encarar a vida vocacional já havia sido antevista pelos místicos alemães, especialmente por Tauler, mas era ainda mais reacionária na prática luterana, porque menos justificada (a justificação não cabia, afinal o comando divino contido na Bíblia era o que importava - a postura dos místicos era mais parecida com a dos pietistas e dos Quakers - WEBER, 2005, p. 44).

É interessante pensar que, séculos depois, este misticismo pré-luterano alemão seria fonte de grande influência para o romantismo, com conceitos como a unio mystica, a união harmônica e absoluta entre a alma humana e Deus, sendo singularmente significativos na obra de Hölderlin e em diversos outros expoentes deste movimento e do idealismo alemão, como em Hegel, nos quais a influência do romantismo e do protestantismo eram inegáveis. Este romantismo, por sua vez, tinha caráter marcadamente anti-burguês, e Löwy ${ }^{109} \mathrm{o}$ associa, a um anticapitalismo e antimodernismo, que, no entanto, como visto, nasce da própria origem da modernidade. ${ }^{110}$

\footnotetext{
Alterou-se o trecho para melhor adequar o conceito, ademais incompatível com as afirmações constantes nas notas de fim, que revelam esta amplitude do termo, do qual carece a língua portuguesa semelhante. A tradução de Talcott Parsons utiliza alternativamente as palavras affairs, obligations e activity. Optou-se, nesta adaptação pela palavra ampla atividades, grafada em itálico, e pela palavra vocação, também assim gravada.

${ }^{109}$ Em sua obra Romanticism against the Tide of Modernity.

${ }^{110}$ Weber explica: "A suprema experiência religiosa a que aspira a piedade luterana, tal como se desenvolveu notadamente no curso do século XVII, é a unio mystica com a divindade. Como já sugere a própria expressão, que nesses precisos termos é desconhecida da doutrina reformada, trata-se de um sentimento substancial de Deus: a sensação de uma real penetração do divino na alma crente, qualitativamente igual aos efeitos da contemplação à maneira dos místicos alemães e caracterizada por um cunho de passividade orientada a preencher a saudade do repouso em Deus e por um estado interior de pura disponibilidade. [Ora, em si mesma, uma religiosidade misticamente orientada — conforme ensina a história da filosofia — não só é perfeitamente compatível com um senso de realidade marcadamente realista no plano do dado empírico, mas também muitas vezes, em conseqüência de sua rejeição das doutrinas dialéticas, chega a ser para este um suporte direto. E indiretamente a mística também pode, por assim dizer, trazer benefícios à conduta de vida racional. É claro, porém, que a esse seu modo de relação com o mundo falta a valoração positiva da atividade externa.] Além do mais, no luteranismo a unio mystica se combinava com aquele sentimento profundo de indignidade decorrente do pecado original, que devia manter o crente luterano na poenitentia quotidiana destinada a curti-lo na humildade e
} 
O dever expresso no Beruf se torna, então, intransigivel, a ponto de, mesmo diante da alteração das circunstâncias, ele ser seguido, porque o fim, o telos da ação, não pode ser alterado. Neste sentido, alguns filósofos utilitaristas provenientes de sociedades nas quais conceitos como a predeterminação protestante, em maior ou menos grau, tiveram impacto teológico ou filosófico sobre uma concepção mais liberal de fins/valores têm, como no relato de Benjamin Franklin (WEBER, 2007, p. 46), uma racionalidade mundana que justifique a univocidade da autoridade-Razão na determinação dos fins sociais, e, consequentemente, dos meios para atingi-los. É digno de estudo mais aprofundado a origem comum tanto desta concepção filosófica quanto da concepção racionalista de Kant, porquanto em ambas se percebe essa univocidade dos fins e (consequentemente) dos meios prédeterminados - seja a satisfação materialista dos desejos da maioria, seja a preservação da dignidade do homem ambos incompatíveis com a doutrina aristotélico-tomista de eudaimonia, que envolveria maior liberdade na determinação de fins e meios, mesmo em questões teológicas (como se pode perceber na distinção entre concilia e praecepta feita no âmbito da doutrina e da prática católica, rejeitada por Lutero, como já visto).

Villey explica esta ideia de uma ordem impassível de gestão humana sobre seus fins mais detalhadamente:

\begin{abstract}
Lutero revela-se, ao contrário dos anabatistas, abundantemente provido desse gosto, que desde então costuma-se qualificar de germânico, desse gosto por uma ordem severa apoiada, se necessário, na força e na violência. [...] Da teologia católica, ele conservou a doutrina de que os preceitos evangélicos da doçura, de não-resistência ao mal só concernem ao indivíduo, não à autoridade como tal, não ao príncipe, não ao policial, não àquele que recebeu vocação (Beruff) de organizar e de punir. Para ele, a ordem é providencial, assim como a força que a ela serve. [...]

Como Lutero concilia sua doutrina da liberdade cristã com seu gosto pela polícia? Por uma consideração bem simples e que prova seu realismo. A plena liberdade cristã vale para os verdadeiros cristãos que estão desobrigados de respeitar qualquer lei e ignoram o direito. Mas existem muitos poucos verdadeiros cristãos; provavelmente nenhum. O pecado invadiu toda a raça humana. Ao lado do reino de Cristo (outro tema agostiniano), há o reino terrestre, o governo dos maus que, entregue a si mesmo, mergulharia no abismo e na decomposição. A Providência cuidou disso.

Cuidou por meio das leis. Pois, embora o reino dos bons prescinda de direito, viva sob o império da liberdade, o mesmo não pode se dar no reino do mundo. Para o governo dos maus, Deus dá primeiro um conjunto de leis positivas divinas, aquelas contidas na Sagrada Escritura, como o Decálogo. [...]

Mas essas regras, outorgadas pela misericórdia divina, ainda são puras demais diante do incremento da corrupção da humanidade. ${ }^{111} \mathrm{O}$ governo de Deus sobre o mundo se exerce, portanto, também pelas leis dos príncipes temporais. Como vimos Lutero dizer: "Quanto a resolver os assuntos temporais, há para isso aqueles cuja vocação é essa, imperadores, príncipes e autoridades. E a fonte da qual devem tirar sua sabedoria não é o Evangelho." "O mundo não pode ser governado segundo o Evangelho; a Palavra de Deus é muito pouco
\end{abstract}

simplicidade indispensáveis ao perdão dos pecados." in WEBER, Max. A ética protestante e o "espírito" do capitalismo. São Paulo: Editora Schwarcz Ltda. 2007, p. 102.

${ }^{111}$ Há uma teologia política aqui presente e que deve ser desvelada. Passos neste sentido serão tomados na próxima seção. 


$$
\text { respeitada para isso." }{ }^{112} 113114
$$

Lutero, diz Villey, determina os limites de exercício da autoridade temporal: ela não se impor às consciências "porque o gládio não tem a capacidade de coagir à fé. Dois séculos depois encontraremos sob a pena de Kant fórmulas semelhantes". Mas essa autoridade sobre os atos exteriores dos homens é, segundo a escritura, ilimitada, e isso envolve o próprio culto, vez que, ainda que manifestação de uma consciência religiosa, é uma manifestação a ela exterior. Na Alemanha, os príncipes imporão aos súditos seus cultos, em especial depois da Paz de westphalia, expondo o vínculo, se não no processo de formação, na conceituação do Estado Moderno, à época,

${ }^{112}$ VILLEY, Michel. A Formação do Pensamento Jurídico Moderno. São Paulo: Editora Martins Fontes, 2009, p. 313. Ainda, no mesmo trecho: "Se certas alas contemporâneas do protestantismo preconizam a não violência, e até a objeção de consciência, não é de Lutero que têm esse traço. Lutero gosta de elogiar o 'gládio', a profissão de soldado e até a profissão de carrasco. 'Deus honra tanto o gládio que o chama de sua própria ordem [...] Por isso a mão que carrega esse gládio e que estrangula não é a mão do homem, mas a de Deus; e não é o homem, mas Deus que enforca, suplicia, decapita, estrangula e faz a guerra, e tudo isso são suas obras e seus julgamentos [...]. Na profissão da guerra, não se deve considerar de que modo ele estrangula, queima, bate, captura [...]. São os olhos estreitos e ingênuos das crianças que o fazem e que não veem no médico nenhuma vantagem, veem apenas que ele corta uma mão ou serra uma perna, mas não percebem e não notam que é preciso fazê-lo para salvar todo o corpo. Portanto, é preciso considerar com olhos de homem a razão pela qual a profissão da guerra ou do gládio estrangula ou age com crueldade; então, essa profissão será considerada divina em si e tão útil e necessária para o mundo como comer, beber ou qualquer outra obra.' [...] O cristão está desobrigado delas, como diz são Paulo; mas ainda não somos cristãos. Não tomemos muito ao pé da letra os exageros da carta a Melanchton ('Pecca fortiter'); de fato, Lutero ensinou a obediência rigorosa que os homens, como pecadores, devem a todas as regras de conduta que a Sagrada Escritura, Antigo e Novo Testamento, possa conter."

${ }^{113}$ Villey afirma que "[A] lógica de seu sistema convida a não reconhecer outras fontes de direito além das leis positivas. E, em primeiro lugar, como acabamos de mencionar, as leis positivas divinas. Pois, embora as leis da Escritura antiga e nova não tenham nenhum valor meritório, nenhuma importância para a salvação (pois não pertencem ao reino de Cristo, são exclusivamente relativas ao governo dos maus), nem por isso deixam de ser obrigatórias. Lutero retoma toda a sua dureza para impor essa carga aos fiéis. Aos comerciantes, por exemplo: vimo-lo proibir a usura ou a caução com base na palavra da Bíblia. Ou ainda aos camponeses revoltados: ordena-lhes deixarem-se pilhar, maltratar, 'estrangular' pelos senhores, deixarem suas filhas serem violadas, oferecer a outra face. Não resistir à força; é porque os preceitos evangélicos, os do 'Sermão da Montanha', são tão obrigatórios quanto o Decálogo; e não se deve distinguir, como o catolicismo faz em seu desejo de conciliar o Evangelho e o paganismo, ou seja, Deus e o diabo, entre os conselhos e os 'preceitos'. Os chamados conselhos de perfeição (emprestar sem esperar retorno; deixar-se roubar sem resistência; perdoar setenta e sete vezes) têm o mesmo valor jurídico que o preceito de não roubar ou de não adorar ídolos, e vale para todos e não apenas para os monges que a Igreja católica procurava especializar num 'estado de perfeição'; Lutero elimina essa distinção (sabe-se que 'para zombar do diabo' ele desposou uma freira que abandonara o hábito). Foi o retorno à Sagrada Escritura como fonte de direito que o reformador pregou inicialmente - ou seja, o retorno aos procedimentos do agostinismo. [...] Nos séculos XVI e XVII, existiram muitas seitas, especialmente na América do Norte, que pretenderam fazer da lei bíblica a única fonte de seu direito." (in VILLEY, Michel. A Formação do Pensamento Jurídico Moderno. São Paulo: Editora Martins Fontes, 2009, p. 323). Entre elas, a referida na seçãol.1 desta monografia, de puritanos da baía de Massachussets, responsável pelas Fundamental Orders of Connecticut.

${ }^{114}$ Nos diz Villey que, "[T]alvez Lutero, mais do que uma doutrina do direito, seja autor de uma doutrina política. E poderíamos dizer o mesmo da maioria dos filósofos que influenciaram o pensamento jurídico moderno: o direito é para eles apenas uma peça auxiliar da política, tendo na ordem pública sua finalidade essencial. É claro que a doutrina do Estado luterana funda-se inteiramente na Escritura - em certos textos da Escritura pelo menos. Não em Tu es Petrus, por exemplo: Lutero não dá esse texto a atenção que lhe dedicavam os canonistas da Idade Média. Mas especialmente na Epístola aos Romanos (XIII, 1 a 8), de são Paulo, que tem seu análogo em são Pedro (II, 13, 18). Omnis potestas a Deo: 'Não há autoridade que não venha de Deus, e as que existem foram instituídas por ele. Assim, pois, quem resiste à autoridade resiste à ordem estabelecida por Deus, e os que a ela se opõem atrairão sobre si uma sentença de condenação. [...] Pois o príncipe é para ti ministro de Deus para o bem. Mas se fazes o mal, tens motivo para temer, pois não é em vão que ele empunha o gládio, sendo ministro de Deus, encarregado de castigar quem pratica o mal [...].' Trata-se da autoridade do príncipe temporal. Aos olhos de Lutero, a do papa não tem fundamento na Escritura. Mas a autoridade temporal é instituída por Deus; foi por meio dela que Deus cuidou do governo dos maus, do reino do mundo. Portanto, a lei divina nos ordena obedecer ao príncipe secular, a seus comandos, a suas leis." in VILLEY, Michel. A Formação do Pensamento Jurídico Moderno. São Paulo: Editora Martins Fontes, 2009, p. 324. 
entre Estado e comunidade, e estes príncipes mesmo decidirão quando expulsar de suas terras os asseclas do papa. ${ }^{15}$

Entre Lutero, Aristóteles e são Tomás, há brutal diferença, diz Villey. Para os dois últimos, a lei positiva que é fundamental no Direito, só é válida no que cumpre efetivamente sua função, que é a de ser veículo para o justo. Ela inclusive só é chamada de lei se seu conteúdo se adequar ao conteúdo do justo segundo a ordem natural.

Para Lutero, no entanto, a justiça da lei não é mais condição de sua validade. O que passará a contar dali em diante será sua justiça formal, a condição de que proceda da autoridade. ${ }^{116} 117118$

${ }^{115}$ VILLEY, Michel. A Formação do Pensamento Jurídico Moderno. São Paulo: Editora Martins Fontes, 2009, p. 325. Neste mesmo sentido: "Recomendo sobretudo as páginas de Lutero 'contra as hordas salteadoras e assassinas dos camponeses' [...] 'Em terceiro lugar: dizeis que a autoridade é má e intolerante demais: pois privam-nos do Evangelho, esmagam-nos com encargos pesados demais, fazem perecer nossos corpos e almas. A isso respondo: o fato de a autoridade ser má e injusta não justifica nem conglomeração nem revolta. Pois a tarefa de castigar a maldade não pertence a cada um, mas à autoridade temporal que empunha o gládio, como diz são Paulo" In Ibid., p. 326. Sobre o direito de banimento, ele é tratado com mais profundidade na seção sobre comunidades monacais.

${ }^{116}$ Ibid., p. 327. Ainda, no mesmo trecho: "Lutero nutre outra ideia da lei positiva. Não é que não queira leis justas. Vimo-lo criticar, sem se estender muito sobre o tema, as leis injustas dos senhores. Aconselha-os a legislar, não em conformidade com o direito natural - o príncipe governa contra a natureza corrompida do homem -, mas segundo as ordens de Deus: 'o príncipe é ministro de Deus, encarregado de castigar quem pratica o mal'. Lutero decerto concebe, á maneira agostiniana, a autoridade como auxiliar da lei divina. Mas (além do fato de a Sagrada Escritura, que contém preceitos morais, correr o risco de ser extremamente pobre em soluções jurídicas e, por isso, abrir para a arbitrariedade do legislador humano um campo que pode se tornar imenso) [...] Toda lei deve ser obedecida porque é ordem do príncipe e porque a autoridade do príncipe é de direito divino. A injustiça das leis dos senhores contra os camponeses não as tornou menos válidas."

${ }_{117}$ Villey diz ainda que "a equidade é outro dos temas luteranos, cujo sentido específico, contudo, é preciso entender: alguns intérpretes modernos parecem ter-se enganado. Aparentemente, poderia haver aí um ponto de encontro entre Lutero e os humanistas, grandes partidários [...] da equidade 'ciceroniana'. Summum jus, summa injuria: este famoso axioma, tomado de Cícero ou de Terêncio, encontra-se em Lutero; é caro à escola de Erasmo; ora, a equidade (epieíkeia, mas também íson) já era peça integrante da doutrina de Aristóteles e de são Tomás. Mas há modos diversos, e mesmo opostos, de entende-la. Para o direito natural clássico, ela significa principalmente que o juiz procurará conseguir a justiça, concebida como busca racional da igualdade ou de uma exata proporção (igualdade proporcional), à maneira de Aristóteles. É nesse sentido que os romanos costumam compreender a aequitas, assim como depois deles, como se constata do estudo de M. Kisch, a maioria dos humanistas. A equidade constitui, então, da parte do juiz e da doutrina que guia o juiz, um esforço para alcançar mais justiça ainda do que o próprio texto geral da lei atingira, Outra coisa é aquilo que às vezes se denomina a equidade cristă’: ela seria correção da lei, não pela justiça, mas pela graça, pela piedade, pela misericórdia - subordinação da justiça à caridade. Esta deveria ser a prática do direito da Igreja, segundo os antigos autores do direito canônico ainda apegados às tendências do agostinismo, como o próprio Graciano - para expressá-la, Graciano não emprega a palavra equidade. Outra coisa ainda é a equidade tal como a entende Lutero, embora evidentemente derivada dessa equidade cristã. Lutero nunca perde a oportunidade de recomendar uma certa espécie de equidade, aquela que consiste, para o príncipe, em transcender as fórmulas gerais das leis: 'Assim como um pai de família que, embora fixe o tempo e a quantidade de trabalho e de alimento para seus domésticos e seus filhos, deve, contudo, conservar em seu poder os meios para modificar ou relaxar essas disposições [...]. Digo-o para que não se imagine que basta e que seja bom remeter-se ao parecer dos jurisconsultos.' Não é mais a equidade do jurista, mas a do senhor. A equidade de Lutero parece ser, ao contrário da de Aristóteles, a apologia do bel-prazer, da arbitrariedade do príncipe, da irracionalidade do direito. $\mathrm{O}$ tema da equidade do príncipe esclarece bem o pensamento profundo do reformador: a fonte última do direito é o mandamento arbitrário." in VILLEY, Michel. A Formação do Pensamento Jurídico Moderno. São Paulo: Editora Martins Fontes, 2009, p. 328.

${ }^{118}$ Hasso Jaeger demonstra em trabalhos sobre a mística protestante, segundo Villey, que "[N]ão existe mais 'direito natural" para servir de barreira aos abusos do direito positivo. [...] ao contrário do que se constatará no mundo anglicano, ou mesmo no mundo católico, no pensamento alemão luterano não haverá mais garantia para o indivíduo. Pois o indivíduo natural não é nada no luteranismo, a pessoa humana só começa a ser investida de valor e de 'dignidade' depois de salva pela fé e no reino espiritual, não em sua condição natural." in VILLEY, Michel. A Formação do Pensamento Jurídico Moderno. São Paulo: Editora Martins Fontes, 2009, p.330. 
"Ordem estrita, autoridade, obediência, subordinação - em alemão Obrigkeit, e depois Gehorsam, eis as duas palavras que resumem a posição de Lutero" ${ }^{119}$ Segundo Villey:

Lutero plantou na alma alemã o germe de um tipo original de positivismo jurídico, fundado na fé religiosa, extremo em suas consequências e que se resume ao culto da autoridade e à apologia da obediência e da disciplina. Esse germe frutificará lentamente na filosofia alemã e também no pensamento comum: não só em um Pufendorf, um Kant ou um Stahl, mas também em um Bismarck. E, conhecendo-se a glória da universidade alemã a partir do século XIX, é possível que por mil canais indiretos nós mesmos sintamos sua influência. (VILLEY, 2009, p. 333) 120

O Calvinismo, no entanto, é o responsável pela radicalização da Reforma, para Weber. A sua ética, segundo o referido autor, geraria uma repulsa por parte tanto de católicos quanto de luteranos, por propor uma outra espécie de relação entre a experiência religiosa e a experiência mundana, que ele exemplifica citando o final do Paraíso Perdido, de John Milton, chamado por muitos de a Divina Comédia puritana (e é cabível lembrar, como faz Weber, que a Divina Comédia termina com o poeta contemplando os segredos de Deus passivamente), que descreve a expulsão de Adão e Eva do Paraíso:

They, looking back, all eastern side beheld

Of Paradise, so late their happy seat, Waved over by that flaming brand; the gate

With dreadful faces thronged and fiery arms.

Some natural tears they dropped, but wiped them soon:

The world was all before them, there to choose

Their place of rest, and Providence their guide.

[E olhando pra trás o flanco leste veem

Do Éden, seu prístino lar, quão feliz,

E a espada em faíscas ondulando ali

Na porta, impedida por caras temíveis $\mathrm{E}$ braços ardentes e armas em riste.

Lágrimas brotam e rolam naturais

No entanto enxugadas depressa - pra quê,

Se o mundo inteirinho se entrega a seus pés.

Aonde ir achar um lugar pra parar,

Leal Providência é que os vai conduzir

Enquanto hesitantes e de mão na mão

A sós vão deixando... o Éden lá atrás.]

E isso logo após o Arcanjo Miguel, responsável pela expulsão dos dois, lhes dizer:

\section{[...] Onlyadd}

\footnotetext{
119 "Posição de monge, condicionado à obediência e que, desprezando a razão humana, pretende haurir apenas na Escritura os princípios da conduta humana; de monge para quem, afinal, só conta o reino espiritual, e que só quer conhecer o outro de uma maneira negligente e superficial. Porque são Paulo prega aos cristãos a obediência às autoridades superiores, como regra de conduta espiritual, Lutero conclui apressadamente, na ordem temporal, pela autoridade de direito divino dos poderes vigentes e pelo valor absoluto de suas ordens. As considerações exclusivamente religiosas de que partiu levaram-no a uma forma de positivismo singularmente duro e simplista, que exalta sem nenhuma ponderação as leis positivas, mas que faria uma longa fortuna na Alemanha luterana." in VILLEY, Michel. A Formação do Pensamento Jurídico Moderno. São Paulo: Editora Martins Fontes, 2009, p. 331 .

${ }^{120}$ Por fim, Villey conclui que "[À] medida que o mundo germânico se impregna da religião de Lutero, pode até manter o rótulo do direito natural (como é o caso em Pufendorf, em Kant), mas perderá progressivamente seu sentido autêntico.” (in VILLEY, Michel. A Formação do Pensamento Jurídico Moderno. São Paulo: Editora Martins Fontes, 2009, p. 322.) Estas partes todas são colacionadas porque trazem à baila questões de formação da mentalidade do povo alemão que serão correlacionadas com outros aspectos de significativa importância mais à frente.
} 
Deeds to thy knowledge answerable; add Faith;

Add virtue, patience, temperance; add love,

By name to come called Charity, the soul

Of all the rest: then wilt thou not be loth

To leave this Paradise, but shall possess

A Paradise within thee, happier far

[...Trabalha, faz,

Junta feitos à doutrina, junta fé,

Paciência, temperança, dom de si, Junta amor, alma de tudo mais, o amor Que um dia caridade chamarão.

E a contragosto assim não perderás

O paraíso em vão, que um paraíso

É o que farás com as mãos, e mais feliz...] $]^{121}$

Nas palavras de Weber: "Sente-se logo que se lê que esta poderosa expressão da séria atenção que o

Puritano dedica a este mundo e aceitação de sua vida como uma missão não poderia de forma alguma vir da mente de um escritor medieval." (WEBER, 2005, p. 46)

Para Villey, o pensamento de Calvino prolonga as tendências do pensamento de Lutero. ${ }^{122} 123{ }^{124}$ Ele,

\begin{abstract}
${ }^{121}$ A tradução de ambos os trechos é de Antônio Flávio Pierucci, e estão contidos, junto da análise que os acompanha, na edição da Companhia das Letras referida, às fls.79. Cabe só ressaltar que a frase “[...] but shall possess/ A Paradise within thee [...]” significa literalmente "possuirão um paraíso dentro de si”, o que ressalta um aspecto individualista muito próprio do Calvinismo, que Weber também nota: "O mundo está destinado a isto [e apenas a isto]: a servir à autoglorificação de Deus; o cristão [eleito] existe para isto [e apenas para isto]: para fazer crescer no mundo a glória de Deus, cumprindo, de sua parte, os mandamentos Dele. Mas Deus quer do cristão uma obra social porque quer que a conformação social da vida se faça conforme seus mandamentos e seja endireitada de forma a corresponder a esse fim. O trabalho social do calvinista no mundo é exclusivamente trabalho in majorem Dei gloriam \{para aumentar a glória de Deus\}. Daí por que o trabalho numa profissão que está a serviço da vida intramundana da coletividade também apresenta esse caráter. Nós vimos já em Lutero a derivação da divisão do trabalho em profissões a partir do 'amor ao próximo'. Mas aquilo que nele não passou do estágio de um ensaio ainda incerto, [de pura construção ideal], nos calvinistas tornouse parte característica de seu sistema ético. O 'amor ao próximo' - já que só lhe é permitido servir à glória de Deus e não à da criatura - expressa-se em primeiro lugar no cumprimento da missão vocacional-profissional imposta pela lex naturae, e nisso ele assume um caráter peculiarmente objetivo-impessoal: trata-se de um serviço prestado à conformação racional do cosmos social que nos circunda. Pois conformar e endireitar em relação a fins esse cosmos, que segundo a revelação da Bíblia e também segundo a razão natural está manifestamente talhado a servir à 'utilidade' do gênero humano, permitem reconhecer como o trabalho a serviço dessa utilidade social [impessoal] promove a glória de Deus e, portanto, por Deus é querido. [A eliminação total do problema da teodiceia e de todas as indagações sobre o 'sentido' do mundo e da vida, em função das quais outros se dilaceravam, era para o puritano algo tão evidente por si só quanto o era — por razões bem diversas — para o judeu. E, aliás, também para a religiosidade cristã não mística, em certo sentido." in WEBER, Max. A ética protestante e o "espírito" do capitalismo. São Paulo: Editora Schwarcz Ltda. 2007, p. 98.

122 "Encontro nele os mesmos fundamentos, emprestados em ambos da Bíblia, a mesma preocupação de regular a conduta humana com base nas leis positivas divinas e, em consequência, o mesmo traço característico: a destruição do direito concebido à maneira de Aristóteles, ou de Roma, ou da Igreja Católica. Em suma, encontro nele a mesma substância, no que se refere ao essencial. [...] sua obra possibilitará compreendermos mais claramente o contraste entre o direito e a moral, e esse é um fator decisivo para a compreensão do novo pensamento jurídico." in VILLEY, Michel. A Formação do Pensamento Jurídico Moderno. São Paulo: Editora Martins Fontes, 2009, p. 337.

${ }^{123}$ Da moral calvinista. Pode-se dizer que visa "regrar por meio de leis propriamente cristãs todos os atos da vida temporal. Não há mais monges no calvinismo, nem preceitos 'cerimoniais', nem 'obras piedosas' que sirvam para dar a salvação. Mas, com uma tenacidade que suscita nossa admiração, vemos Calvino propor-se a cristianizar a totalidade da vida, até nos seus mínimos detalhes." in VILLEY, Michel. A Formação do Pensamento Jurídico Moderno. São Paulo: Editora Martins Fontes, 2009, p. 344.

${ }^{124}$ Não se pretende aqui dissertar sobre o governo de Genebra, cidade da qual Calvino era pastor e guia espiritual, mas basta dizer que "o controle da moral, na Constituição de Genebra, competia aos 'anciãos', que deviam ser dirigidos pelos pastores - com efeito, sob a ascendência de Calvino. Era um controle efetivo de cada instante; os anciãos tinham por missão, na comunidade cristã, vigiar e denunciar qualquer fiel que fosse pego em flagrante delito de demorar-se no cabaré, ou - pior - de dançar, a fortiori, de fornicar.
\end{abstract}


segundo Villey:

\begin{abstract}
Deseja ardentemente poder aplicar a maravilhosa rede de prescrições de conduta social contida na lei judaica, e mais ainda nos profetas e nos livros sapienciais, como os provérbios do Eclesiastes, que ensinam uma sabedoria prosaica e um tanto utilitária, feita para o uso cotidiano. [...] A todos, prescreve o trabalho [...]. Deus não admite o ócio em que vivem os monges. Quer a prosperidade, bendiz o trabalho da agricultura e os homens industriosos, e não menos o comércio, fator de prosperidade, e, no comércio, a lealdade e o respeito escrupuloso dos contratos. [...] é essa parte de sua doutrina que Max Weber (que, aliás, escolhe seus exemplos na moral dos puritanos, mais que na do próprio Calvino) considerava historicamente significativa. Pois, embora essa pregação siga escrupulosamente a Bíblia, nem por isso deixa de estar adaptada às tendências da burguesia moderna. ${ }^{125} 126$
\end{abstract}

Toda a moral fazia parte da vida cristã’ e Calvino a mantinha sob seu controle." in VILLEY, Michel. A Formação do Pensamento Jurídico Moderno. São Paulo: Editora Martins Fontes, 2009, p. 339. Sobre o Calvinismo, na mesma linha do comentário feito sobre o impacto da Reforma na vida das pessoas, Weber especifica: "A dominação do calvinismo, tal como vigorou no século XVI em Genebra e na Escócia, na virada do século XVI para o século XVII em boa parte dos Países Baixos, no século XVII na Nova Inglaterra e por um tempo na própria Inglaterra, seria para nós a forma simplesmente mais insuportável que poderia haver de controle eclesiástico do indivíduo. [Foi exatamente assim, aliás, que a sentiram amplas camadas do velho patriciado da época, em Genebra tanto quanto na Holanda e na Inglaterra.] Não um excesso, mas uma insuficiência de dominação eclesiástico-religiosa da vida era justamente o que aqueles reformadores, que surgiram nos países economicamente mais desenvolvidos, acharam de criticar. Como explicar então que naquela época tenham sido justamente esses países economicamente mais desenvolvidos e, como ainda veremos, dentro deles precisamente as classes [médias] 'burguesas', então economicamente emergentes, que não só aguentaram aquela tirania puritana [que até então lhes era desconhecida], mas também desenvolveram, em defesa dela, um heroísmo que as classes burguesas enquanto tais raramente haviam conhecido antes e jamais viriam a conhecer depois: 'the last of our heroisms' \{o último de nossos heró́smos\} como diz Carlyle não sem razão?" in WEBER, Max. A ética protestante e o "espírito" do capitalismo. São Paulo: Editora Schwarcz Ltda. 2007, p. 31.

125 “[...] Aos pobres, lembra o dever de resignação, de aceitação de sua sorte e a proibição do roubo e de qualquer tipo de revolta. Aos ricos, ordena igualmente alimentar os pobres, deixar o pobre respigar, pagar o operário o salário prescrito, saber emprestar gratuitamente. [...] Deus ordenou ao homem prosperar, frutificar e, logo depois da queda, viver pelo suor de seu rosto; os Provérbios louvam o dono ou a dona de casa, a 'mulher forte', que não medem esforços e são laboriosos, previdentes, capazes de poupar." in VILLEY, Michel. A Formação do Pensamento Jurídico Moderno. São Paulo: Editora Martins Fontes, 2009 , p. 346.

${ }^{126}$ Sobre a doutrina jurídico-política de Calvino, Villey afirma que ela "consiste em entregar toda a distribuição das riquezas e das honrarias entre os cidadãos à absoluta soberania da autoridade temporal. Essa resposta leva Calvino, assim como Lutero, ao positivismo jurídico. Não seria preciso insistir nisso, se não tivesse se arraigado o hábito de vez por outra misturar o pensamento de Calvino com o de calvinistas franceses ou anglo-saxões. Todo mundo sabe que, mais tarde, as circunstâncias levaram os huguenotes franceses em luta contra o rei da França (ou os protestantes da Inglaterra, da Escócia, da América) a defenderem doutrinas hostis à monarquia, e mais ou menos liberais ou democráticas, uma doutrina dos direitos naturais subjetivos do indivíduo. Mas esta não era de forma alguma a posição calvinista. Para nos certificarmos disso, basta abrir a Instituição cristã: escolhamos, ou o capítulo XVI, 'Do governo civil', ou a Epístola dedicatória. A obra foi dedicada ao rei da França, Francisco I, numa época em que Calvino podia esperar que ele se inclinasse pela Reforma: empenha-se em tranquiliza-lo sobre a lealdade dos protestantes e a oposição total deles aos desvios dos anabatistas. Mas pouco importa: sua boa-fé é indubitável; expõe seu pensamento sincero, tirado, como o de Lutero, da Sagrada Escritura. Portanto: que todo homem se submeta às autoridades superiores, pois elas vêm de Deus; Deus ordena a obediência mesma aos tiranos; que nenhum súdito se envolva nos assuntos públicos temporais sem ser convidado pelo Príncipe; que todo súdito obedeça ao príncipe como uma criança a seu pai. O respeito de Calvino pela causa da ordem temporal é tal que considera aqui o regime monárquico como o melhor regime, e um regime de direito divino. É claro que numa leitura completa do capítulo 'Do governo civil' descobriremos algumas passagens capazes de abrir caminho para as futuras teses liberais dos monarcômacos - abre-se aqui espaço para, colacionando o trazido na obra em questão, explicar o que significa a palavra monarcômaco: seguidores do direito natural e adversários do absolutismo monárquico no séc. XVII - protestantes. São Pedro diz que se deve preferir obedecer a Deus a obedecer aos homens: isso subtrai a fé íntima da esfera atribuída à autoridade secular. Por outro lado, nem toda constituição é uma monarquia pura; existem constituições em que a monarquia é temperada por uma mistura de oligarquia; nesse caso, a obediência ao príncipe ver-se-á limitada por aquela devida aos magistrados secundários. A soberania legislativa costuma ser reconhecida mais ao 'magistrado' que ao monarca. Enfim, na história, Deus suscita vingadores contra tiranos. Eis com que justificar mais tarde as revoltas dos huguenotes franceses ou dos puritanos na Inglaterra, e mais tarde ainda as dos camisardos - seita calvinista francesa, pietista de inspiração profética, rebelada contra o Édito de Nantes e derrotada em 1715 - e dos 
Como Weber relembra, nem o rico poderia se abster de trabalho, vez que o trabalho não estava tanto relacionado à supressão das necessidades, mas ao comando apostólico constante na Segunda Carta aos Tessalonicenses, capítulo 3, versículo 10. É Baxter quem o reafirma o mandamento, vez que, se Deus havia preparado um Beruf para cada um, era necessário que cada um se ativesse a ele para a plena realização da Providência, que, no entanto, se realizaria da mesma forma, e a não realização do Berufseria apenas a marca da ausência da graça característica do não-eleito. Essa interpretação providencial da ordem econômica havia começado, segundo Weber (WEBER, 2005, p. 106), na escolástica. Mesmo o capitalismo, apesar de ser rejeitado por parcelas significativas da doutrina católica como turpitudo, já era aceita por alguns moralistas, especialmente os associados à escola nominalista, pois, entendendo sua inevitabilidade, buscavam justificativas (WEBER, 2005, p. 35). ${ }^{127}$

Realmente há a semelhança aqui entre o mecanismo do trabalho enquanto ascese intramundana e a

\begin{abstract}
'loucos de Deus'. Mas estas são portas apenas entreabertas; do conjunto da exposição de Calvino, deduz-se claramente que ele nega aos súditos o direito de resistência contra a autoridade estabelecida. Concluirei afirmando que, para Calvino, o direito que se impõe aos súditos tem por fonte as disposições do príncipe. A atribuição das riquezas e das honrarias é da alçada das decisões do príncipe, apenas do príncipe, ou de seus delegados, como seus ministros ou seus juízes, mas não dos juristas como tais, não da doutrina jurídica. Esta não goza, em presença das leis, de nenhuma missão, de nenhum poder de direção ou de controle; pois também os juristas são apenas súditos do príncipe. O positivismo jurídico, como o entendo, é um fruto do protestantismo. É verdade que vocês também encontrarão, em nossos manuais contemporâneos de teologia católica, a tese de que o zelo pela 'justiça distributiva' repousa exclusivamente na autoridade estatal; mas isso parece contradizer o verdadeiro pensamento de são Tomás; e essa tese provavelmente representa, na escolástica, uma deformação tardia. É o protestantismo de Calvino, fundado, como o de Lutero, nos textos da Epístola aos Romanos, que traz para o pensamento moderno essa decisiva promoção das leis positivas humanas, prescrevendo aos súditos, ante as ordens do magistrado, uma atitude de obediência irrestrita." (in VILLEY, Michel. A Formação do Pensamento Jurídico Moderno. São Paulo: Editora Martins Fontes, 2009, p. 353.) À questão do comando, trazida acima, se une, portanto, esta observação histórica de Villey.

127 "Entre outros, já Tomás de Aquino (a quem por comodidade nos reportamos uma vez mais) havia concebido o fenômeno da divisão do trabalho e da articulação profissional da sociedade como emanação direta do plano de Deus para o mundo. Acontece, porém, que a inserção dos seres humanos nesse cosmos resultava ex causis naturalibus e era aleatória (ou, para usar o vocabulário da escolástica, 'contingente'). Já para Lutero, como vimos, a inserção mesma dos seres humanos nas profissões e nos estamentos já dados, que é um produto da ordem histórica objetiva, torna-se ela própria uma emanação direta da vontade divina e, portanto, vira uma obrigação religiosa para o indivíduo permanecer na posição social e nos limites em que Deus o confinou. Isso tanto mais, quando justamente as relações da espiritualidade luterana com o 'mundo' em geral são incertas desde o começo e incertas continuavam. Das linhas de pensamento de Lutero, que de sua parte jamais rejeitou por completo a indiferença paulina pelo mundo, não era possível extrair princípios éticos para com eles dar forma ao mundo; por isso era preciso assumir o mundo como ele é, e não se devia aplicar o rótulo de obrigação religiosa senão a isso. Na visão puritana, por sua vez, outro é o matiz do caráter providencial do jogo recíproco de interesses econômicos privados. Segundo o esquema de interpretação pragmática dos puritanos, é pelos seus frutos que se reconhece qual é o fim providencial da articulação da sociedade em profissões. Ora, acerca desses frutos Baxter deixa fluir argumentos que em mais de um ponto lembram diretamente a célebre apoteose que Adam Smith faz da divisão do trabalho. A especialização das profissões, por facultar ao trabalhador uma competência (skill), leva ao incremento quantitativo e qualitativo do rendimento do trabalho e serve, portanto, ao bem comum (common best), que é idêntico ao bem do maior número possível. Por mais que a motivação seja puramente utilitária, por mais cabal que seja seu parentesco com muitos pontos de vista já correntes na literatura profana da época, desponta aquele timbre caracteristicamente puritano logo que Baxter, no ápice de sua discussão, toca o seguinte motivo temático: 'Fora de uma profissão fixa, os trabalhos que um homem faz não passam de trabalho ocasional e precário, e ele gasta mais tempo vadiando que trabalhando', e o mesmo se nota quando ele conclui da seguinte maneira: 'e aquele (que tem uma profissão) fará seu trabalho de forma ordenada, enquanto um outro patina em perpétua confusão, com negócios a fazer não se sabe onde ou não se sabe quando; ... eis por que uma profissão fixa (certain calling, noutras passagens se lê stated calling) é o melhor para todo mundo'." in WEBER, Max. A ética protestante e o "espírito" do capitalismo. São Paulo: Editora
\end{abstract}


operação da graça divina com a tese, restrita a sacerdotes no catolicismo, da distinção entre opus operatume opus operantis, ${ }^{128}$ presente na Mediator Dei, apesar desta distinção, ao ser sancionada no Concílio de Trento, ter sido usada para combater a doutrina protestante da sola gratia. A razão desta semelhança? A Reforma, como já se deve ter percebido, tencionava transformar todos em sacerdotes. Só que isso só faria sentido em uma lógica específica: como o ofício (e aqui se indeferencia profissão e dever propositalmente) do sacerdote é a operação do sacramento, o ofício do trabalhador é o trabalho; e como o sacerdote só é sacerdote pelo cumprimento do seu ofício, assim também deve ser com qualquer outro trabalhador. E, como o sacerdote tinha um munus que destacava-o ontologicamente a partir de sua função, no protestantismo o munus seria realização do ofício, através do qual a graça era prestada a Deus. Neste sentido, de fato, o que Barroso afirma se concretiza: todos são nobres no protestantismo, todos têm um munus, todos têm dignitas.

Pode-se ver aqui, enfim, a relação mais estreitada entre o puritanismo, o racionalismo idealista e o utilitarismo, este último na medida em que o fim, unicamente material, é visto como resultado de uma causa eficiente, não como o telos, a partir da percepção de que há a perda, nas três doutrinas intelectuais, do controle sobre o telose sobre o resultado. No caso do Puritanismo, o telos pré-determinado é a glória de Deus, e

o dever orienta a ação, como a "verdade científica" orienta no utilitarismo. É uma materialização (no sentido de interpretação de materialista) do telos, claramente decorrente de um abandono da crença de que a razão possa indagar sobre os fins últimos do homem. ${ }^{129}$

Schwarcz Ltda. 2007, p. 145.

${ }^{128}$ Se colaciona aqui passagem referente ao tema: "A distinção entre opus operatum e opus operantis na encíclica Mediator Dei provém da tradição escolástica e encontrou sua sanção no Concilio de Trento: 'se alguém diz que através dos sacramentos da nova lei a graça não é conferida ex opere operato, mas que somente a fé na promessa de Deus é suficiente para obter a graça, anathema sit [seja anátema]'.

Nessa formulação exprime-se um princípio que define de modo constitutivo a praxe litúrgica da Igreja: a independência da eficácia e da validade objetiva do sacramento do sujeito que o administra em concreto. Opus operatum designa assim o ato sacramental em sua realidade efetual, opus operantis (a formulação mais antiga é, na verdade, opus operans) designa a ação enquanto é realizada pelo agente e é qualificada por suas disposições morais e físicas. A origem da distinção surge nas disputas sobre a validade do batismo que dividem a Igreja entre os séculos III e IV e cujo ápice será a controvérsia entre Cipriano e o pontífice Estêvão em 256 e aquela entre Agostinho e os donatistas entre 396 e 410 . Em ambos os casos, trata-se de afirmar, contra Cipriano e contra os donatistas, a validade do batismo conferido por um herético ou por um ministro indigno, ou seja, assegurar a eficácia objetiva do sacramento e da ação sacerdotal para além das condições subjetivas que poderiam torná-los nulos ou ineficazes. Assim como aqueles que foram batizados por Judas, escreve Agostinho, não devem ser batizados de novo, porque foi Cristo que os batizou, aqueles que foram batizados por um bêbado, por um homicida ou por um adúltero, se receberam o batismo cristão, foram batizados por Cristo'. Como ocorre em toda instituição, trata-se de distinguir o indivíduo da função que exerce, de modo a assegurar a validade dos atos que ele realiza em nome dela." In AGAMBEN, Giorgio, Opus Dei: Arqueologia do Ofício. São Paulo: Boitempo Editorial, 2013. P. 30.

${ }^{129}$ MacIntyre fala sobre o assunto: "A razão não pode fornecer, afirmam essas novas teologias, compreensão genuína do verdadeiro fim do homem; esse poder da razão foi destruído pela queda do homem. 'Si Adam integer stetisset', na visão de Calvino, a razão poderia ter desempenhado o papel que Aristotle atribuiu a ela. Mas agora a razão é impotente para corrigir nossas paixões (não é desimportante que os pontos de vista de Hume sejam aqueles de alguém que foi criado como um calvinista). No entanto, o contraste entre o homem-como-ele-é e o homem-como-ele-poderia-se-se-ele-tivessepercebido-seu-telos permanece e a lei moral divina ainda é a professora que nos remove da estado primeiro para o último, mesmo que apenas a graça nos permita responder e obedecer aos seus preceitos. $\mathrm{O}$ jansenista Pascal é um ponto de referência peculiarmente importante no desenvolvimento desta 
Há toda uma relação entre os elementos presentes em uma determinada mentalidade historicamente condicionada. No caso de Lutero, o resultado da fusão destes elementos foi uma nova forma de pautar a ética, mais associada à noção de dever e de comando, e, consequentemente à noção de submissão, do que a que a precedera. Após Lutero, os reformadores buscaram até as mesmas influências que o monge alemão acolhera. Mas era a sua ideia original que guiará muito dos outros reformistas. A leitura da Bíblia não será mais uma leitura livre, ao menos hermeneuticamente falando. Será uma leitura pautada no diálogo com Lutero. Calvino dialoga. E amplifica muitas das expressões de comando de Lutero, dialogando com mais autores não religiosos, mas que igualmente punham a questão do dever e do comportamento adequado. É isso que permite a Weber dizer que

O princípio ascético do "autocontrole" fez também do puritanismo um dos pais da disciplina militar moderna. [...] Os Ironsides de Cromwell, brandindo a pistola engatilhada mas sem disparar, marchando a trote compacto sobre o inimigo, eram superiores aos "Cavaleiros" não por uma passionalidade de dervixes, mas ao contrário por seu sóbrio autocontrole, que os mantinha sempre nas mãos dos chefes, ao passo que estes, com os seus tempestuosos ataques de cavalaria, a cada vez dissolviam em átomos na própria tropa. (WEBER, 2007, p. $221)^{130}$

Segundo Villey:

Para Calvino, o fatoé fonte de direito. Percorrendo suas obras, chama minha atenção que ele convide o legislador simplesmente a manter a ordem atualmente existente. [...]

Por que essa submissão ao fato? A teologia de Calvino sabe fornecer uma razão clara: é porque as situações existentes nos são dadas tais quais pela Providência. Eis o sentido específico da noção calvinista (bem diferente da noção de ordem natural aristotélica tomista) de ordem providencial. 'Este mundo é governado pela mão e pelo conselho' (de Deus) 'e as coisas humanas não são conduzidas ao acaso, ou fortuitamente, como os homens profanos imaginam'. Por isso, foi Deus quem operou a partilha dos bens tal como está dada de antemão perante nossos olhos. ${ }^{131} 132$

\footnotetext{
história. Pois é Pascal quem reconhece que a concepção protestante-cum-jansenista da razão é em importante sentido semelhante à concepção da razão em voga na mais inovadora filosofia e ciência do século XVII. A razão não compreende essências ou transiçōes da potencialidade para o agir; esses conceitos pertencem ao esquema conceitual desprezado da escolástica. Daía a ciência antiaristotélica estabelece limites estritos aos poderes da razão. A razão é calculadora; pode avaliar verdades de fato e relações matemáticas, mas nada mais. No âmbito da prática, portanto, pode falar apenas de meios. Sobre fins, deve permanecer silenciosa. A razão não pode nem mesmo, como Descartes acreditava, refutar o ceticismo; e, portanto, uma conquista central da razão de acordo com Pascal é reconhecer que nossas crenças são, em última análise, fundadas na natureza, no costume e no hábito." In MACINTYRE, Alasdair. After Virtue: A Study in Moral Theory. Notre Dame: University of Notre Dame Press, 3 Ed, 2007, p. 53.

${ }^{130}$ Villey, no entanto, relembra que"[O]utras seitas tinham pretendido extrair do Evangelho um código de princípios jurídicos, tendendo mais ou menos para o comunismo, o liberalismo ou a anarquia: fora esta a tentação de Martin Bucer em Estrasburgo, e sobretudo dos anabatistas; é a grande fonte de utopias, gênero que ganha então grande impulso, com Thomas More, Rabelais ou Campanella. E, a partir do século XVI, tampouco faltarão calvinistas que interpretem nesse sentido os escritos de Calvino: daí sairão as doutrinas liberais individualistas com um grande futuro pela frente." in VILLEY, Michel. A Formação do Pensamento Jurídico Moderno. São Paulo: Editora Martins Fontes, 2009, p. 352.

${ }^{131}$ Em outras palavras, a ciência do direito, no entender dele, deve reger-se sobretudo pelo fato, que ela visa a conservar. O direito visa sobretudo a manter. Assim, no capítulo XVI sobre o governo civil lê-se que um dos principais papéis do magistrado é a 'conservação do seu bem': os particulares não caem em estado de pecado quando 'recorrem à ajuda do Magistrado para a conservação de seus bens'. Pois, com esse fim, é permitido servir-se da força pública. 'Mas quando alguém vir que poderá defender seu bem sem ofensa nem dano à caridade [... nada comete contra a sentença de são Paulo. Principalmente se for coisa de grande importância, e cujo dano seja para ele um agravo.' A justiça exige que 'cada um guarde o que é seu’'; ela prescreve 'a cada um conservar o seu.' 'Que os juízes mantenham fielmente a cada um o que lhe pertence' etc. [...] 'Devemos estimar que o que cada um possui não lhe adveio fortuitamente, mas pela distribuição daquele que é soberano-mor e senhor de tudo.' Calvino diz ao pobre: 'És
} 
No Calvinismo, pela Teoria da Providência, o crente se torna instrumento da vontade divina dentro da comunidade. Mas a prova de que o homem atua como instrumento da Providência se dá através da ação ascética, ou seja, na ação cultivada dentro dos mandamentos como um meio de dar glória a Deus. ${ }^{133}$ Esta doutrina já se assemelha muito à doutrina kantiana de obediência ao dever independente do resultado, justificada tão somente pelo comando. ${ }^{134}$

Agamben (AGAMBEN, 2011, p. 272 e ss.) realiza uma análise da penetração da doutrina teológica providencialista de Malebranche na teoria política de Rousseau, que entende-se ser importante para explicar a dinâmica da interação entre providencialismo (teológico, de matriz agostiniana, e cosmológico, de matriz estoica) e filosofia política moderna (denominação que engloba a filosofia política kantiana). Ele afirma a existência de diversos estudos que, traçando um longo percurso, que envolve Arnauld e Pascal, o próprio Malebranche e Fenélon, se dedicam ao estudo da influência do pensamento teológico na França dos séculos XVII e XVIII no

um sacrílego quando vais pilhar o bem alheio, quando vais arrancar da mão de Deus o que ele reservara para um outro.” in VILLEY, Michel. A Formação do Pensamento Jurídico Moderno. São Paulo: Editora Martins Fontes, 2009, p. 359/60.

${ }^{132}$ Villey explica as consequências dessa forma de pensar que podem ser extraídas imediatamente, no entanto: "Logo, foi essa a via que o direito moderno tomou. Na escola do direito natural em particular, a do calvinista Grócio e de seus sucessores, a tendência será fundar a propriedade de cada um na posse prévia; doravante, o principal modo de 'aquisição originária' da propriedade será a ocupação, dos imóveis, dos impérios e dos territórios coloniais. Grande novidade, absolutamente estranha aos textos romanos, como demonstrou um memorial de M. Arnaud. Eis os fundamentos do sistema liberal inglês e francês - revolucionário." in VILLEY, Michel. A Formação do Pensamento Jurídico Moderno. São Paulo: Editora Martins Fontes, 2009, p. 361.

133 "A comunidade dos eleitos com o próprio Deus só poderia ter lugar e ser perceptível pelo fato de Deus agir (operatur) através deles e eles tomarem consciência disso — pelo fato, portanto, de a ação nascer da fé operada pela graça de Deus e essa fé, por sua vez, ser legitimada pela qualidade dessa ação. [Profundas diferenças quanto às condições decisivas para a salvação, válidas em geral para a classificação de toda religiosidade prática, encontram expressão aqui: o crente pode certificar-se do seu estado de graça quer se sentindo como receptáculo, quer como ferramenta da vontade divina. No primeiro caso, sua vida religiosa tende para a cultura mística do sentimento; no segundo, para a ação ascética. Do primeiro tipo estava mais perto Lutero; o calvinismo pertencia ao segundo.] O reformado \{o calvinista\} também queria salvar-se sola fide. Entretanto, dado que já na visão de Calvino os simples sentimentos e estados de espírito, por mais sublimes que possam parecer, são enganosos, a fé precisa se comprovar por seus efeitos objetivos a fim de poder servir de base segura para a certitudo salutis: precisa ser uma fides efficax [e o chamado à salvação, um effectual calling (termo da Declaração de Savóia)]." In WEBER, Max. A ética protestante e o "espírito" do capitalismo. São Paulo: Editora Schwarcz Ltda., 2007, p. 103 (com alterações significativas com base na versão de Talcott Parsons, p. 68).

134 "Ora, se perguntarmos: em quais frutos o reformado [o calvinista] é capaz de reconhecer sem sombra de dúvida a justa fé, a resposta será: numa condução da vida pelo cristão que sirva para aumento da glória de Deus. Ebo que leva a isso é deduzido de sua divina vontade diretamente revelada na Bíblia ou indiretamente manifestada nas ordens do mundo criadas segundo fins (lex naturae). É possível controlar seu estado de graça comparando em especial seu próprio estado de alma com aquele que segundo a Bíblia era próprio dos eleitos, dos patriarcas por exemplo. Só quem é eleito possui a verdadeira fides efficax, só ele é capaz, por conta do seu renascimento (regeneratio) e da santificação (sanctificatio) da sua vida inteira, de aumentar a glória de Deus por meio de obras boas realmente, não apenas aparentemente boas. E estando consciente de que sua conduta - ao menos no tocante ao seu caráter fundamental e ao seu propósito constante (propositum oboedientiae) — se assenta numa força que nele habita para a maior glória de Deus, e portanto [não é apenas] desejada por Deus, [mas sobretudo] operada por Deus, alcança ele aquele bem supremo a que aspirava essa religiosidade: a certeza da graça. Que ela possa ser alcançada é corroborado por 2Cor 13,5. E, portanto, por absolutamente incapazes que sejam as boas obras de servir como meio de obter a bem-aventurança eterna- já que o próprio eleito permanece criatura, e tudo o que ele faz permanece infinitamente aquém das exigências divinas — , não deixam de ser imprescindíveis como sinais da eleição. [Elas são o meio técnico, não de comprar a bem-aventurança mas sim de perder o medo de não tê-la.] Nesse sentido, de vez em quando elas são designadas diretamente como 'indispensáveis à salvação', ou a possessio salutis é vinculada a elas" in WEBER, Max. A ética protestante e o "espírito" do capitalismo. São Paulo: Editora Schwarcz Ltda., 2007, p. 104 . 
pensamento de Rousseau. Um dos principais, e escolhido por Agamben para nele se debruçar, é o de Patrick Riley The General Will before Rousseau. Patrick Riley tenta provar que os conceitos de vontade geral e vontade particular, presentes na obra de Rousseau, cujo trabalho Kant muito admirava, teriam vindo dos debates acerca da função da Graça divina (ou seja, da Providência) no governo do mundo, na França dos séculos XVII e XVIII.

Aqui interessa afirmar, desde já, que a vinculação existente entre estes teólogos e o Calvinismo, bem como Kant, fica muito clara se eles forem reinsertos nas suas circunstâncias históricas. A discussão que envolvia todos eles era a Providência a partir da visão calvinista. Arnauld, Malebranche, Fenélon e Pascal estavam todos, uns de um lado, uns do outro e uns na terra de ninguém, participando das batalhas que ocorriam à época na França entre huguenotes, quietistas, jansenistas e católicos, muitos deles inclusive, se verificados historicamente seus trabalhos, participando de mais de um campo durante o todo da discussão, ou afirmando que estavam em um campo ao mesmo tempo em que defendiam a ideia de um outro, ou ainda, atuando a favor de dois campos ao mesmo tempo.

A questão da sola fide, ou seja, a salvação só pela fé, só pela graça divina, dogma maior do protestantismo, de uma forma geral, como foi visto, tinha se alterado um pouco na experiência calvinista, a ponto da devoção à ação intramundana ser considerada a forma superior de ascese. No entanto, rapidamente começaram a haver debates que por vezes resultavam em doutrinas ecléticas, antes que a instituição Igreja Católica pudesse atuar.

Estas doutrinas em geral se fundavam na valorização do já citado ancestral comum de ambos os envolvidos, católicos e protestantes, ou seja, Santo Agostinho, e não na adesão a um sistema fechado de crenças, seja pela própria mutabilidade do protestantismo (e do protestantismo calvinista, mas especificamente), seja pela própria indefinição do dogma. $\mathrm{O}$ conceito contemporâneo de dogma como algo absolutamente estanque não era tão comum à época, por causa da vivacidade dos debates teológicos. Quando as coisas escapavam do controle, o caminho era a excomunhão, mas, na maior parte das vezes, o Papa atuava como um debatedor, corrigindo a doutrina, junto com ou em conflito com os concílios (a infalibilidade papal para questões teológicas e morais só foi afirmada em 1870).

Na maior parte da França, os elementos que mais geraram adesão ao protestantismo calvinista foram o rigorismo dos hábitos e uma espécie de mística da união com Deus, mais semelhante, na maior parte das vezes, a elementos da doutrina luterana, ou de doutrinas de ascendência luterana, do que calvinistas. $\mathrm{O}$ racionalismo, por sua vez, estava em seus dias de glória na França, e muitos teólogos, dentre os quais o próprio Malebranche, aderiram ao cartesianismo, e tentaram aplicar a lógica matemática do cartesianismo ao governo de Deus do mundo através da Providência.

Junto deste corpo de ideias vinha o neoestoicismo, que será estudado mais à frente, recuperando elementos da Providência estóica, que, apesar de não ser o grande foco dos humanistas de matriz neoestoica, 
acabou influenciando no pensamento de muitos filósofos. Essa noção de Providência tinha certo apelo na Antiguidade e pode ser encontrada mesmo em Orígenes, nos primórdios do Cristianismo. ${ }^{135}$

Agamben afirma que, apesar da diversidade dos estudos relativos à penetração dos produtos deste período na vida de Rousseau, nenhum se dedicou a estudar (a exceção de Alberto Postigliola, de cujos resultados Agamben discorda) o fato de Rousseau ter literalmente transferido uma noção do campo de estudo da teologia para o da política, com grandes efeitos para a definição teórica, no autor, das relações entre soberania e governo, lei e poder executivo. Segundo Agamben: "Através do Contrato Social, a tradição republicana herdou, sem qualquer reserva, um paradigma teológico e uma máquina governamental acerca dos quais está longe de se conscientizar." (AGAMBEN, 2011, p. 272)

Segundo o autor italiano, Foucault acerta ao afirmar que a teoria da soberania de Rousseau está em função de sua teoria de governo (ou "economia pública"), mas não percebe o quão radical é a relação entre esta doutrina e a aqui referida doutrina francesa da Providência. ${ }^{136}$ No seu Contrato Social, Rousseau reafirma a articulação entre vontade geral e poder legislativo, de um lado, e governo e poder executivo do outro. Ele afirma que esta divisão seria, na verdade, não uma divisão, mas uma articulação entre estes poderes, que comporiam juntos um poder supremo indivisível. Esta é, por acaso, exatamente a doutrina filosófica que fundamenta o Estado contemporâneo, e Agamben a retraça as discussões acerca do papel de cada uma das pessoas da trindade divina no Cristianismo dos primeiros séculos.

\footnotetext{
${ }^{135}$ Filósofo que, para Agamben, traz pela primeira vez a moderna noção de história, qual seja, a de um processo dotado de um sentido, mesmo que este sentido esteja escondido "Se, ao contrário do que acontece na historiografia clássica, a história tem para nós um significado e uma direção que o historiador precisa poder entender; se não é uma series temporum mas algo em que um propósito e um destino estão em jogo, isto é, em primeiro lugar, devido ao fato de que nosso conceito de história foi planejado de acordo com o paradigma teológico da revelação de um 'mistério' que é, ao mesmo tempo, uma 'economia', uma organização e uma 'dispensação' da vida divina e humana. Ler a História equivale a decifrar um mistério que nos envolve de forma essencial, [...] uma 'economia' que livremente organiza criaturas e eventos, deixando-lhes seu caráter contingente e até mesmo sua liberdade e suas inclinações." in AGAMBEN, Giorgio. The Kingdom and the Glory. For a Theological Genealogy of Economy and Government (Homo Sacer II. 2). Stanford: Stanford University Press, 2011, p. 45 e ss. Na mesma sequência de páginas, o autor ainda afirma que é esta noção de Providência, que os cristãos partilham, atrelada a uma rede dinâmica, e por vezes paradoxal, de significados, que constrói as vases da ciência da história que em Hegel e Marx alcançam o limite de seu progressismo (no sentido de "ser imagem da crença no progresso"). "O link estabelecido pela teologia cristã entre oikonomia e a história é crucial para a compreensão da filosofia ocidental da história. Em particular, é possível dizer que o conceito de história no idealismo alemão, de Hegel a Schelling e até Feuerbach, não é nada além de uma tentativa de pensar o vínculo 'econômico' entre o processo da revelação divina e a história (adotando os termos de Schelling, que citamos anteriormente, a 'co-pertença' da teologia e oikonomia). É curioso que, quando a esquerda hegeliana rompe com este conceito teológico, só pode fazê-lo na condição de que a economia em um sentido moderno, ou seja, a auto-produção histórica do 'homem', seja colocada no centro do processo histórico. Nesse sentido, a esquerda hegeliana substitui a economia divina por uma economia puramente humana." (p. 46)

${ }^{136}$ Agamben afirma que "[O] que é decisivo deste ponto de vista é a distinção e a articulação da soberania e do governo, que está na base do pensamento político de Rousseau. 'Exorto também os meus leitores,' escreve em seu artigo sobre a Economie politique, 'a distinguir cuidadosamente a economia pública, sobre a qual vou falar, e que chamo de governo, da autoridade suprema, que chamo de soberania - uma distinção que consiste em um ter o direito legislativo e, em certos casos, obrigar o corpo da própria nação, enquanto o outro tem apenas o poder executivo e só pode obrigar indivíduos particulares." in AGAMBEN, Giorgio. The Kingdom and the Glory. For a Theological Genealogy of Economy and Government (Homo Sacer II. 2). Stanford: Stanford University Press, 2011, p. 274.
} 
Neste mesmo sentido funciona a Providência: uma geral, atua no todo da Terra e impõe as leis de Deus ao homem. A outra, particular, influencia a vida privada de cada homem. Elas não são independentes entre si, nem mesmo representem uma divisão da vontade divina, mas a Providência particular, na verdade, nada mais é do que, como Malebranche afirma, uma atualização da vontade geral de Deus. Da mesma forma em Rousseau, o governo (poder executivo), afirma coincidir com a soberania da lei, da qual, no entanto, se distingue, enquanto sua emanação e atualização. A própria utilização do conceito de emanação por Rousseau, foi polêmica no período, por estar carregada de sentidos teológicos relacionados a doutrinas da Providência e que tratam acerca da criação do mundo no neoplatonismo, em Boécio, em Eurígena e na teologia judaica, não existindo paralelo para seu uso fora desse contexto. Seu uso, pensa Agamben, só pode ter sido deliberado, vez que, em francês, o único significado do termo emanação era dentro da doutrina católica da divisão de funções dentro da Trindade. Com isso, Agamben continua, ele provavelmente estava tentando demonstrar a impossibilidade de divisão do conceito de soberania (AGAMBEN, 2011, p. 275).137

Rousseau não nega de onde tirou sua influência. Ao tratar da dificuldade de reconciliar "liberdade pública e a autoridade do governo", ele afirma que a solução veio por meio da "mais sublime de todas as instituições humanas, ou melhor, de uma inspiração divina, que ensina à humanidade a imitar cá embaixo os decretos inalteráveis da divindade". Como na Providência em Malebranche, a vontade geral em Rousseau só submete os homens para torna-los mais livres(AGAMBEN, 201 1, p. 277 - ou assim Rousseau o afirma).

Agamben, citando Christian Marouby, afirma que Adam Smith também se baseou no providencialismo para sua teoria econômica. Além de citar frases de Santo Agostinho, São Tomás de Aquino, Lutero e Bossuet que trazem a metáfora da mão invisível de Deus governando o mundo (metáforas acerca da Providência, obviamente), ele apresenta uma citação de Smith que, buscando justificar a sua ideia de causas primeiras e segundas, meios e fins (quando trata da economia da natureza), após falar que estas causas remetem ao "Autor da natureza", se utiliza dos "antigos estóicos" e de sua ideia de Providência para comparar com a sua. Ademais, Agamben afirma que Perrot teria demonstrado a influência que autores franceses como Mandeville, Malebranche,

\footnotetext{
${ }^{137}$ Agamben ainda afirma: "Rousseau concebe o governo como o problema político essencial; Por outro lado, ele minimiza o problema de sua natureza e sua fundação, reduzindo-o à atividade de execução da autoridade soberana. A ambigüidade que parece resolver o problema do governo apresentando-o como a mera execução de uma vontade e lei gerais pesou negativamente não só sobre a teoria, mas também sobre a história da democracia moderna. Pois essa história nada mais é que a progressiva descoberta da substancial inverdade da primazia do poder legislativo e da conseqüente irredutibilidade do governo à mera execução. E se hoje estamos testemunhando a dominação esmagadora de uma soberania popular desprovida de significado pelo governo e pela economia, isso talvez signifique que as democracias Ocidentais estão pagando o preço político de uma herança teológica que eles assumiram sem querer por meio de Rousseau. A ambiguidade que consiste em conceber o governo como poder executivo é um erro com algumas das conseqüências mais profundas na história do pensamento político ocidental. Significou que o pensamento político moderno se perdeu em abstrações e mitos vazios como o Direito, a vontade geral e a soberania popular, e não conseguiu confrontar o problema político decisivo. O que nossa investigação mostrou é que o problema real, o mistério central da política não é soberania, mas governo; Não é Deus, mas o anjo; Não é o rei, mas o ministério; Não é a lei, mas a polícia - ou seja, a máquina
} 
Pierre Nicole e Pascal teriam tido em Smith (AGAMBEN, 2011, p. 283). Da mesma forma, só que segundo Deleule desta vez, Agamben afirma que a noção de Hume, e das ciências da natureza, de uma forma geral, de Lei, estaria vinculada a esta ideia de Providência, Deus assumindo o papel de legislador universal (AGAMBEN, 2011, p. 122). Mas ela não vem sozinha, e viria acompanhada de um abandono da filosofia grega e das reflexões acerca da causa final das coisas (considerando o modelo aristotélico-tomista das causas). ${ }^{138}$

Em suma, conclui Villey:

Melhor ainda que a de Lutero, graças à sua clareza metódica, à excelência intelectual de seu autor, a doutrina de Calvino nos ajuda a compreender qual foi o efeito do protestantismo sobre o pensamento jurídico da Europa moderna. Na história da filosofia do direito, a Reforma aparece como um prolongamento do esforço de Ockham e de sua escola; continua o movimento, inaugurado pela escolástica franciscana, de regressão rumo ao agostinismo medieval, destruidor do direito natural. Relega ao abandono as aquisições do humanismo da escola de são Tomás; faz com que se perca a sábia teoria do direito que o mundo devia à filosofia dos gregos; em sua obsessão pelo retorno às fontes bíblicas, amputa a moral clássica de uma de suas peças mais sutis e também mais necessária, a justiça social e o direito. Foram estas as vias que conduziram ao positivismo moderno. (VILLEY, 2009, p. 363)

O julgamento de conotação profundamente negativa do autor francês não é partilhado nem em sua

conotação, nem em sua integralidade. A experiência protestante, o próprio Villey admite, tem consequências

governamental que formam e apoiam." in AGAMBEN, Giorgio. The Kingdom and the Glory. For a Theological Genealogy of Economy and Government (Homo Sacer II. 2). Stanford: Stanford University Press, 2011, p. 276.

${ }^{138}$ Esta discussão não concerne propriamente ao presente trabalho, mas foi citada anteriormente, e pode ser basicamente resumida da seguinte forma: Aristóteles definia quatro causas que permitiriam o conhecimento da natureza de cada coisa no mundo, como a causa formal (aquela que define o que aquela coisa é considerada em relação as outras coisas) e a causa final (que define qual é o fim, ou para que que aquela coisa existe - inclusive o homem). No período da primeira escolástica, trabalharam outra, a causa instrumental que, segundo alguns (entre outros, De La Torre Rangel e De La Torre de Lara, La dicta-dura de los instrumentos: ciência y derecho deshumanizados, artigo publicado na Revista Direito e Práxis, Rio de Janeiro, Vol. 07, N. 13, 2016, p. 690-720, da Faculdade de Direito da UERJ) teria sido o conceito epistemológico fundamental da modernidade, a partir do pensamento nominalista. Agamben trabalha a conceituação de Heidegger sobre o tema das quatro causas e, quando o filósofo alemão afirma que "[O] que a técnica é enquanto concebida como meio revela-se se remetermos a instrumentalidade à quádrupla causalidade", o italiano afirma que ele "poderia ter lembrado que, como ele certamente sabia, uma tentativa de inserir o instrumento na categoria de causalidade foi feita pelos teólogos medievais. A partir do século XIII, ao lado da causa eficiente, eles definiam uma quinta causa, a qual chamam de instrumentalis. Como uma inversão ousada, o instrumento, que Aristóteles jamais poderia ter classificado entre as causas, é agora considerado um tipo especial de causa eficiente. O que define a causa instrumental - por exemplo, o machado nas mãos de um carpinteiro que fabrica uma cama - é a particularidade de sua ação: por um lado, ela age não por virtude própria, mas em virtude do agente principal (a saber, o carpinteiro); por outro, opera segundo sua própria natureza, que é a de cortar. Ela só serve, pois, a um fim diferente na medida em que realiza o próprio. O conceito de causa instrumental nasce, portanto, como desdobramento da causa eficiente, que se cinde em causa instrumental e causa principal, assegurando, assim, à instrumentalidade um estatuto autônomo." (p. 95) Ainda segundo Agamben, Tomás de Aquino afirma que a Paixão de Cristo, por exemplo, seria a causa da redenção da humanidade, mas não por ser sua agente principal, ou ainda pela autoridade desta paixão, mas por ser causa instrumental. A causa instrumental, segundo o filósofo, age em modo dispositivo. "Dispositio é a tradução latina do termo grego oikonomia, que indica o modo como, pela própria articulação trinitária, Deus governa o mundo para a salvação dos homens. De acordo com essa perspectiva, que implica um imediato significado teológico, uma operação dispositiva (ou, sem forçar, poderíamos dizer um dispositivo) é uma operação que, seguindo a própria lei interna, realiza um plano que parece transcendê-la, mas lhe é na realidade imanente, assim como na economia da salvação Cristo opera dispositive - ou seja, segundo uma 'economia' - a redenção dos homens." (p. 95) Dante diria o mesmo acerca da força em relação ao poder imperial, afirmando que aquela só poderia ser reconhecida como a causa instrumental deste, segundo Agamben. Esta forma de pôr os elementos do poder em relação se preserva na forma funcionalizante como os cidadãos são vistos em relação ao Estado na modernidade e, em especial, a partir da matriz kantiana. Todas as menções a Agamben in AGAMBEN, Giorgio. O Uso dos Corpos. São Paulo: Boitempo Editorial, 2017. 
políticas das mais variadas e, ao mesmo tempo que rompe com uma concepção até então unânime de autoridade política, força esta autoridade política a reagir e se reinventar teoricamente. À ideia de reforma da Igreja não pode ser imputada qualquer culpa pela quebra de um sistema que já, governamentalmente, apresentava profundos sinais de decadência. A Igreja, como bem se sabe pelas 95 Teses de Lutero, tinha sérios problemas de conflito entre as expectativas geradas pelo apostolado (de conformação evangélica), seu governo (o exemplo maior seria a prática da venda de indulgências e a política que envolvia o Santo Ofício) e a sanção metafísica a este governo (a conotação providencial que adquiriam as resoluções eclesiásticas). Diversas revoltas e heresias precederam o rompimento absoluto, a maior parte se fundando na mesma base teórica (Santo Agostinho, ainda que mais ou menos combinado de forma heterodoxia com conceitos maniqueístas e neoplatonistas) e o movimento religioso popular, em especial nas regiões que hoje formam a Alemanha, em geral aderia a estas concepções mais místicas de fé. Foram estas concepções, no entanto, que fundaram a prática de experimentação política dentro do protestantismo e que, dentro do catolicismo, ficava restrita aos mosteiros.

\section{O (NEO)ESTOICISMO NA PAISAGEM MORAL KANTIANA}

A própria dificuldade de se estabelecer uma definição precisa do momento onde a noção de Dever deixa de ser substancialmente religiosa e passa a ser laica, ${ }^{139}$ ou melhor, não só a noção de Dever em si, mas o Estado e o

\footnotetext{
${ }^{139}$ Mesmo assim, é difícil separar absolutamente. Expondo mais claramente a relação entre o monasticismo e o apreço pela antiguidade latina mais própria do período relacionado ao humanismo, Weber mostra como Richard Baxter se utiliza de fontes tanto da Bíblia (os Provérbios de Salomão), de Plutarco e dos escritos de ascese de São Bernardo de Claraval e São Boaventura, para afirmar "pecaminoso é tudo o que é contrário à razão dada por Deus como norma de ação. Não só as paixões que têm um conteúdo pecaminoso, mas todos os sentimentos que são insensatos e intemperantes como tal. Eles destroem o comedimento e, como coisas da carne, nos impedem de dirigir racionalmente toda ação e sentimento a Deus e, assim, insultam-No". E estas fontes, afirma Weber, não são apenas fontes de leitura metafísica, mas fontes de doutrinas práticas de ascese. A citação de Weber é de WEBER, Max. A ética protestante e o "espírito" do capitalismo. São Paulo: Editora Schwarcz Ltda. 2007, p. 222, com muitas alterações baseadas na tradução de Talcott Parsons (p. 197). Weber ainda afirma que é verificável a influência de Descartes no Puritanismo (p. 72, tradução de Talcott Parsons) e, apesar de não ter sido este um dos aspectos aqui explorados da paisagem kantiana, vez que deliberadamente se optou por excluir a epistemologia kantiana do trabalho aqui desenvolvido no que ela transbordasse o que Agamben considerasse significativo para a construção de seu argumento, é significativo que, no sistema kantiano é só o diálogo com todos estes elementos e destes elementos entre si que o justificam. O subjetivismo fundado em uma hermenêutica estritamente focada nos elementos explicitados no texto bíblico acerca da norma divina é verdadeira abertura metafísica para um racionalismo que, em Descartes, não implicava necessariamente consequências existenciais. $\mathrm{O}$ solipsismo último de Descartes, consequência de seu racionalismo, era hipotético. É aí que ocorre o parentesco. Tanto a crença protestante na solidão do eleito (p. 61 da tradução de Talcott Parsons) quanto o solipsismo cartesiano são fenômenos de uma mudança psicológica cujas origens não cabem ser estudadas aqui, mas que tem a ver com o ambiente do período. Ao mesmo tempo, suas radicalizações, bem como a radicalização de uma visão instrumentalizante da natureza, são as responsáveis pela destruição dos elementos da ordem medieval, bem como da abertura para construção de novas ordens. Weber afirma que "[A]quele grande processo histórico-religioso do desencantamento do mundo que teve início com as profecias do judaísmo antigo e, em conjunto com o pensamento científico helénico, repudiava como superstição e sacrilégio todos os meios mágicos de busca da salvação encontrou aqui sua conclusão." (p. 96 da tradução da Companhia das Letras). É este desencantamento do mundo promovido pelo protestantismo na religião, pelo racionalismo na metafísica e pelo humanismo na ética e na política que destroem a ordem medieval, tão fundada no poder mágico do sacramento. Ao mesmo tempo que erigem uma nova ordem, a partir de certos aspectos seus, no entanto, seus advogados preparam, consciente ou inconscientemente, uma reação. Elementos desprezados pela nova
} 
próprio modus pensandi, estruturado em torno de Universidades que tinham como seu principal curso o curso de Teologia, é um forte indício de que este momento específico de laicização seja apenas um embuste intelectual, mas com gravosas consequências, como se viu, no sentido de que, perpetuase a mesma estrutura de pensamento, apenas tirando a Divindade da equação dialética e colocando a autoridade política em seu lugar. ${ }^{140}$

Desviando dessa discussão, é com o humanismo jurídico e com o jusnaturalismo racionalista, este sob forte influência do neoestoicismo, ${ }^{141}$ que se afirma o conceito de Dever como parte do conceito de Justo. Neste sentido, estabelecem-se deveres de solidariedade e deveres de não causar dano a outrem, de restituir o alheio, de manter a palavra dada e de reparar os danos causados, sendo a cada um destes prevista uma sanção, o que importará na indeterminação definitiva da concepção de Dever na esfera religiosamoral com uma noção-espelho noção na esfera jurídica. ${ }^{142}$

ordem, como o voluntarismo, aspectos mais panteístas do humanismo, um misticismo idealista não rejeitado pelo protestantismo, ajudaram a gestar a reação romântica ao iluminismo do qual Kant, o autor sobre o qual aqui se debruça, é o exemplo último (em todos os sentidos possíveis - os românticos alemães mesmo tomaram dele certos elementos). Dentre estes elementos, está o comunitarismo, que será estudado mais a frente.

${ }^{140}$ V. C. SCHMITT, Politische Theologie, e M. FOUCAULT, A Verdade e as Formas Jurídicas.

${ }^{141}$ Que Villey alega não ter conhecido a concepção de Direito Natural, como anotado durante o trabalho.

${ }^{142}$ Villey é a quem novamente se remete para a elucidação do que é o neoestoicismo e qual é a sua relação com o estoicismo original; ele afirma, sobre o antigo, que "[P]odemse distinguir cronologicamente três etapas do estoicismo: o antigo, o dos fundadores, com Zenão de Cício (332-362), e depois seus sucessores, Cleanto e Crisipo; o médio, que sem dúvida conservou pouco a pureza da doutrina introduzindo nela ideias tomadas de outras seitas: os mais famosos chefes da escola são então Panécio de Rodes, que se encontra em missão diplomática em Roma no ano de 146, autor de um grande tratado de moral, e Posidônio, que talvez tenha sido o mestre de Cícero, cujos tratados de moral pertencem a essa escola (o De officiis adapta o tratado de Panécio); é então que, na elite romana, começam a se multiplicar as adesões à seita; vem, por fim, o novo estoicismo, com Sêneca, Epicteto e Marco Aurélio, cuja tendência é voltar às fontes primeiras da doutrina, pelo menos no que se refere ao rigorismo moral de seus fundadores." (p. 454) Sobre o pensamento estóico, Villey afirma que em sua primeira etapa ele não contemplava o direito como objeto de reflexão: "O próprio dessa filosofia, voltamos a repetir, foi voltarse para a moral da vida privada. Na nova ordem política helenística que sucedeu às grandes conquistas de Alexandre, agora que as liberdades cívicas da antiga Grécia desapareceram, não cabe mais ao filósofo imiscuir-se nas coisas públicas. Zenão, Clenato e Crisipo delas se desinteressam; chegam até a negar a pólis, com as falsas distinções que ela comporta entre os ricos e os pobres, cidadãos, metecos e inimigos; opõem a ela o universo indistinto da cosmopólis deles; ocupam-se apenas da vida, totalmente individual, do 'sábio'; do sábio que vive apenas para si, ou para o universo, mas mal se digna a dirigir a vista para as aparências ilusórias e convencionais das instituições estatais. Eis uma atitude que implica o desprezo e o olvido do direito; pois a justiça particular tal como a concebia Aristóteles, atividade dos legisladores e dos juízes, era uma função pública. Os estóicos, como também se sabe, são deterministas. Os fundadores da doutrina consideram ser uma grande ilusão imaginar que se pode mudar algo no curso das coisas; tudo o que acontece está determinado, regido pelo logos soberano que comanda a história. A pura moral estóica não é uma moral ativa, ela só ensina ao sábio submeter-se aos acontecimentos tais como acontecem, a aceita-los de bom coração; é uma moral de intenções e não dá prática. Como também diz uma famosa máxima de Epicteto: 'Não desejes que os acontecimentos ocorram tais como quererias, mais queire-os tais como ocorrem e serás feliz.' Nessas condições, por que tender a realizar uma melhor partilha dos bens e a fazê-la ser respeitada? Por que essa filosofia iria se preocupar com o direito? Aliás, que tipo de interesse poderia o procedimento jurídico ter aos olhos do estóico? Um dos ensinamentos da autêntica moral estóica é que as vantagens exteriores não têm nenhuma importância real. Somente a virtude é desejável, somente ela traz a felicidade; o sábio estóico é feliz 'crucificado' sob as torturas como se fosse 'num leito de delícias'; e para ele é 'indiferente' padecer a condição de escravo ou ter nascido rei. Riqueza, pobreza, escravidão, direitos de cidadania, honrarias, tudo isso não conta para o estoicismo, que, como bem vemos, instala-se num nível diferente do do direito. $\mathrm{O}$ mesmo repetirão Epicteto e Sêneca, e Cícero expõe uma doutrina idêntica, mesmo se seu bom senso de romano o impeça de aderir a esses paradoxos, que, contudo, eram os da escola segundo os fundadores. Portanto, quando os estóicos falavam de 'justiça', ou de homem justo ou reto, era uma justiça que nada tinha de jurídica. O estoicismo ignorava congenitalmente o direito." (p. 459) Em sua segunda etapa, porém, Villey afirma que " $\mathrm{E}] \mathrm{m}$ contato com o mundo romano, menos refinado (que o grego - N. do A.), mais 
Villey reconhece que a grande fonte do neoestoicismo foi Cícero, ${ }^{143}$ e apesar de Cícero ser, acima de tudo, um filósofo eclético, é impossível não ver em sua aproximação com o estoicismo uma intenção, desnudada por Agamben, como afirmado acima, de manutenção de uma ordem social que se dissolvia, na qual o Senado Romano ainda detinha poder político, face a ameaça dos vitoriosos generais que conquistavam poder expandindo as fronteiras da República, todos representados naquele que pôs fim, enfim, ao regime: Júlio César. Há que se reconhecer a coincidência das circunstâncias políticas, qual seja, a de dissolução de um determinado modelo

dinâmico, Panécio ou Posidônio (e sem dúvida muito mais ainda o próprio Cícero) temperam os exageros estóicos; cedem quanto ao determinismo e põem-se a louvar uma moral ativa, não mais indiferente às obras, mas que, antes, reabilita a dedicação à pólis e a participação do sábio nas funções públicas. As condições da vida romana diferem das do mundo oriental, e o espírito romano não está maduro para uma moral de passividade e solidão. E não se pode esperar de Cícero que ele professe com certa sinceridade a indiferença aos bens terrestres e às vantagens exteriores; ele concorda que não são 'bens', o que não impede que sejam 'preferíveis'. É quando a moral estóica sofre a contaminação da moral das outras escolas, sobretudo da de Aristóteles, que era bem mais pé no chão. Entre o vício e a 'virtude' única e perfeita do sábio - que era aceitar passivamente tudo o que o destino lhe apresentava -, o estoicismo médio construiu uma moral 'intermediária', moral das condutas 'preferíveis', dos 'deveres' (de officiis), acompanhada da prescrição das condutas apropriadas para uma ou outra situação, de 'deveres de estado', de uma pluralidade de virtudes particulares e diferentes segundo o setor onde se exercem, entre as quais encontramos, deformadas, acomodadas ao estoicismo, aquelas descritas por Aristóteles. [...] As obras dos estóicos dessa época intermediária aceitaram, modificando-as mais ou menos, algumas ideias aristotélicas. [...] E Cícero continua sendo o eclético por excelência. Cícero, ocupado demais, apressado demais para ter o tempo de construir um pensamento coerente, não se limita ao estoicismo; junta a essa filosofia, de qualquer maneira, outros ensinamentos que extraiu de outras fontes; não ignorará totalmente a justiça particular e chegará a reproduzir, aqui e acolá, mais ou menos a sua definição, principalmente nas suas obras de retórica. Assim, no De inventione, encontraremos a formulação de que a justiça é a virtude que atribui a cada um aquilo de que ele é digno, tendo em conta as necessidades comuns: Justitia est habitus animi, commune utilitate conservata, suam cuique tribuens dignitatem. Também o De oratore indicará como fim do direito a conservação do que, pela lei ou pelo costume, pode ter sido instituído de igualdade nas relações entre cidadãos: Sit ergo in jure civili finis hic: legitimae atque usitatae in rebus causisque civium aequibilitatis conservatio. Essa finalidade de uma certa proporção ou de uma certa igualdade a ser mantida na partilha dos bens e das honrarias entre cidadãos será indicada com bastante frequência nas obras de Cícero." (p. 460) Todas as citações extraídas de VILLEY, Michel. A Formação do Pensamento Jurídico Moderno. São Paulo: Editora Martins Fontes, 2009.

143 "Para nós, a fonte mais frutífera será a mesma que ocupa o lugar central nos estudos dos humanistas, ou seja, Cícero. Notemos que Cícero não é apenas estóico: ele é eclético e presta-se a todas as influências da literatura grega. Por meio de seu mestre, Antíoco de Ascalão, sofreu a influência da Academia. Tem curiosidade pelo epicurismo, teria feito editar Lucrécio, e, em seus diálogos, não deixa de fazer algum membro da escola filosófica apresentar sua doutrina. Costuma ler Aristóteles e conhece todos os lugarescomuns do pensamento grego, que lhe são transmitidos pela Retórica, uma das disciplinas que cultiva com predileção. Sabe que a filosofia da política e do direito deve ser buscada de preferência em Platão e em Aristóteles. Mesmo o estoicismo a que ele se refere e que ocupa em sua obra o lugar mais importante - e que, sobretudo, ele segue totalmente em seus trabalhos de moral -, não é um estoicismo puro: é o estoicismo médio de Posidônio, que deve ter apreendido de Rodes, e de Panécio, que pilhou. Mistura de doutrinas heterogêneas, o que não facilita a análise, Cícero desnatura-o ainda pelo que acrescenta de produção própria, ele que pessoalmente é retor, sempre ávido de influenciar a opinião das massas, o mais distante possível dos métodos secos de raciocínio dos fundadores do estoicismo, o maior inimigo de seus paradoxos, ele que tem o gosto pela vida ativa e pela vida pública, que se entrega à política e às grandes questões judiciárias - totalmente ao contrário de um Zenão. Mas é precisamente por isso que as obras estóicas de Cícero, mais que as de nenhum outro autor, são a melhor fonte para a história que estamos retraçando - ou seja, a das relações entre essa filosofia e o direito. Cícero, cujo temperamento e cujas ocupações o inclinam para o direito e para a política, já começa a aproximar o estoicismo do direito. Não que sua obra já seja uma verdadeira filosofia do direito, pelo menos sua obra estóica: Cícero é bastante dependente de modelos gregos, intensamente desprovido de força criativa para realizar por si só essa metamorfose. O De officiis, o De finibus (ousaria até dizer: os primeiros livros do De legibus) são obras de moral e seria um equívoco buscar nelas uma teoria do direito e de suas fontes. Mas, pelo fato de ele mesmo ter um pé em ambos os domínios, como filósofo na moral e como advogado no direito, e de ir buscar os exemplos que ilustram seus tratados de moral em sua experiência judiciária, já podemos adivinhar em sua obra que relações o estoicismo pode manter com o direito, e que frutos poderia produzir quando aplicado a esse terreno." in VILLEY, Michel. A Formação do Pensamento Jurídico Moderno. São Paulo: Editora Martins Fontes, 2009, p. 455. 
social, diferentes nos dois momentos históricos (a República Romana e a Ordem Feudal), e a ascensão de um modelo semelhante, a autocracia cesarista e do soberano dos sécs. XV e XVI.

"Basta passar os olhos por um tratado de direito humanista para constatar a invasão de textos tirados de Cícero." Bodin, por exemplo, oferece, no começo de sua obra Juris universi distributio, um esboço de teoria das fontes. Todas as suas definições do direito natural são tomadas de Cícero. ${ }^{144} \mathrm{O}$ direito em Bodin, assim como em Cícero, toma a forma de leis estruturadas hierarquicamente entre as quais deve predominar a lei da Razão.

Haverá quem diga que esse quadro de leis já estava em Suárez: é verdade, mas Suárez filia-se a uma filosofia parecida. Haverá ainda quem objete que ele já estava, como algumas variantes, em substância em são Tomás: sem dúvida, mas são Tomás abstinhase de identificar o sistema das "leis" com o conjunto das fontes do "direito"; ele sabia que o direito procede, para além das fórmulas das leis, da busca ativa de cada jurista. Em Bodin não se trata mais desse método de busca do justo: o juiz tem apenas de seguir as leis, e, acima das leis escritas, há apenas a razão comum, único limite para a soberania do chefe de Estado legislador..$^{145}$

Fruto maior do neoestoicismo é Grócio, para quem "[A] fonte última das regras de direito reside na moralidade." Villey apela:

Recordemos a formação calvinista de Grócio, misturada com a corrente neo-estóica: a razão do homem, que é sua natureza, ditalhe uma moral que Grócio confunde com a moral cristã. Não nos surpreende encontrar o fenômeno da absorção do direito na moralidade num autor

\footnotetext{
${ }^{144}$ Como a de que as sementes (semina) do direito estão nos princípios racionais que existem a priori na alma humana

${ }^{145}$ Neste sentido, durante o Renascimento humanista, Villey afirma que "[A] influência das fontes literárias latinas e principalmente de Cícero leva à simplificação do direito. O direito acessível ao orador e aos homens de bem é um tema muito disseminado nas obras de Cícero, e os humanistas não negariam tê-lo extraído daí. Significa que o direito deve ser haurido não numa técnica erudita da observação da vida social, mas na simples razão presente em todos os homens cultos. Nos textos [...] de Erasmo, de Rabelais e de Montaigne, pode-se discernir uma substancial conversão para a concepção estóica das fontes de criação do direito. Nada mais fazem, como sempre, senão reproduzir seus mestres latinos - sem nada de livresco ou de pedante, longe do estilo dos professores... São excelentes tradutores, como não se fazem mais, que proporcionam reviver as doutrinas antigas, em vez de apenas repeti-las. A forma é nova e espontânea. Já a doutrina, ela é antiga. Mas a 'droga' escondida no fundo, a 'substantífica medula', é a doutrina de Cícero. Não atribuamos a eles o que os intérpretes de hoje [...] se contentam com excessiva facilidade em ler em seus textos: o lugarcomum vulgar e simplista de que um jurista não precisaria ser culto, nem muito menos preocupar-se com filosofia. Pelo fato de se exprimir em bom francês, Rabelais seria um adversário da cultura geral clássica? Erasmo, Rabelais ou Montaigne pensam exatamente o contrário; sabem muito bem que não é possível prescindir da filosofia; dizem-no expressamente. Mas a filosofia deles, cujo cérebro está recheado de Cícero, é que o direito é racional, procede precisamente da filosofia moral - 'ex intima philosophia' ('extirpada', traduz Rabelais, 'do meio da filosofia') -, e essa fonte é simples e dispensa as complicações bartolistas. Na verdade, não é em Rabelais, Erasmo ou Montaigne que devemos buscar uma teoria explícita das fontes do direito. Passemos às obras dos juristas. [...] A noção e o próprio termo jus universum são extraídos do De legibus. Em seu Método da História, Bodin louva 'os autores que, formados não só nos usos e preceitos do tribunal, mas também nos mais ricos conhecimentos e numa sólida filosofia, compreendem que a natureza da justiça não consiste em mudar conforme as vontades dos homens, mas em se conformar à lei eterna; que manejam corretamente a regra da equidade, deduzerm as origens do direito de um primeiro princípio, mostram um conhecimento exato de toda a Antiguidade [...]; trazem para a interpretação do direito as discussões dos filósofos sobre as Leis e a República [...] em seu tratado da República, o príncipe nos é mostrado submetido às leis divinas e naturais: as leis divinas são constituídas pelos preceitos do Decálogo, preceitos morais, interpretados sob a égide da filosofia estóica, com a ênfase posta na proibição de infringir as propriedades alheias e o dever de cumprir sua promessa; é também isso que as leis naturais ordenam, que nossa Razão prescreve. Assim, o rei não pode tocar (nem mesmo pelo imposto não consentido) nas propriedades de seus súditos, e deve pagar seus credores. São os dois preceitos dominantes e universais - preceitos, como dissemos, da moral estóica. Abaixo deles vêm as leis humanas editadas soberanamente pelo príncipe, sem nenhuma outra limitação além da de permanecerem subordinadas àquelas leis morais." in VILLEY, Michel. A Formação do Pensamento Jurídico Moderno. São Paulo: Editora Martins Fontes, 2009, p. 544 .
} 
cuja cultura resume a do século XVI ao mesmo tempo que transmite seu legado aos juristas do futuro. Os reformadores protestantes, como vimos, cuidavam de dirigir para a salvação a conduta do indivíduo, de prescrever uma vida conforme à lei da moral divina; o direito era a última de suas preocupações; pensavam o direito como um anexo ou uma sanção da moral. $\mathrm{O}$ mesmo pode ser dito dos diretores de consciência da escolástica espanhola. E também dos humanistas neo-estóicos, tendo a filosofia estóica sido essencialmente, na Grécia e em Roma, uma doutrina moral. Grócio, nutrido de Cícero, de Sêneca e do Evangelho, mais que da jurisprudência romana, acha natural citar a cada página de seu tratado de direito esses moralistas da Antiguidade; [...]

Nota-se imediatamente o papel fundador dos deveres de sociabilidade: '[...] uma dessas coisas próprias ao homem é o desejo de sociedade, isto é, uma certa inclinação para viver com seus semelhantes, não de qualquer maneira, mas pacificamente e numa comunidade de vida tão bem regrada quanto suas luzes sugerem a ele; disposição que os estóicos exprimem com uma palavra tirada dos sentimentos que as pessoas de uma mesma família têm umas pelas outras. [...] o cuidado de manter a sociedade de uma maneira conforme às luzes do entendimento humano é a fonte do direito propriamente assim chamado, e que em geral resume-se a isso: que é preciso abster-se religiosamente do bem alheio; e restituir o que porventura tenhamos nas mãos, ou o proveito que disso se tenha tirado; que se é obrigado a manter a palavra; que se deve reparar o dano causado por culpa própria; e que toda violação dessas regras merece punição [...]

"Esse texto cuidadosamente colocado por Grócio no começo de sua obra e evidentemente extraído da leitura do De officiis" ${ }^{146}$ de certa forma completa magistralmente o percurso que se buscou percorrer neste excurso histórico da ideia de dever, mas não tão somente desta ideia, mas de toda paisagem mental dos autores que a acalentaram, este fruto maior da junção de duas escolas metafísicas que, tão distantes no tempo tanta apologia fizeram desta abnegada ideia de submissão.

Mas há um lapso que não é só temporal, mas genealógico desta paisagem conceitual, que é preenchido por um autor citado tanto por Villey quanto por Agamben como uma peça instrumental na verificação da transição do Direito Antigo para o Direito Moderno, esta transição que não é de forma alguma um rompimento absoluto ou mesmo imediata. Este autor é Samuel Pufendorf.

Pufendorf tem dois trabalhos principais, o De Iure Naturae et Gentium Libri Octo (Oito livros do direito natural e das gentes), de 1672 e o De Officio Hominis et Civis iuxtam Legem Naturalem (Dever do homem e do cidadão de acordo com o direito natural). Estas obras, é importante afirmar, são responsáveis pela fundação do método dedutivista do jusnaturalismo moderno. Ainda que não prescindam das referências a autores cânones da filosofia moderna (Hobbes é um favorito), medieval (nominalista dos ingleses, através do já citado Hobbes e de Descartes) e da Antiguidade, é na natureza do homem que Pufendorf situa o fundamento do Direito. Diferente

\footnotetext{
${ }^{146}$ Os trechos acima extraídos de VILLEY, Michel. A Formação do Pensamento Jurídico Moderno. São Paulo: Editora Martins Fontes, 2009, p. 651. Ainda: “[...] quando cita juristas romanos é como se pertencessem à mesma família, como agentes inferiores da ciência moral. E os barbarismos de Triboniano, a fortiori dos glosadores ou dos bartolistas, parecem merecer com menos frequência uma citação literal que as grandes obras literárias que fazem as delícias do humanismo. Grócio aprendeu a conceber a finalidade do direito como idêntica à da doutrina moral. Donde esta definição do direito: 'Jus est [...] regula actuum moralium obligans ad id quod rectum est.' Portanto, os primeiros princípios do direito são as regras morais inscritas na consciência do homem, tais como as exprimem as obras da moral estóica, e sobretudo Cícero no tratado De officiis."
} 
dos demais filósofos citados até aqui, Pufendorfé, especificamente, um jurista e é considerado um predecessor da escola prussiana. Seu discípulo, Christian Thomasius, também citado por Agamben, aprofunda seu método, afastando as referências a autores antigos e reforçando os vínculos com o pensamento de Grócio, auxiliando o trabalho de recriação de um espaço próprio de reflexão jurídica iniciado por seu mestre. O impacto desta nova escola de pensadores é tanto que a ordem dos capítulos da Doutrina do Direito de Kant segue a do De Officio Hominis, de Pufendorf. (DE LIMA LOPES, 2014, p. 188-93)

Por fim, parece importante ressaltar que, em suma do estudado nesta seção, o neoestoicismo foi instrumentalizado de forma diversa por cada autor. Nos calvinistas, se não temperou o Calvinismo, reforçou a base ética de alguns de seus princípios. Nos católicos, serviu para repudiar Aristóteles.

Aristóteles associa política à poliarquia (muitos poderes, muitas relações) e monarquia à economia (um poder, muitas relações), e esta lógica é mantida no estoicismo. No estoicismo o governo é essencialmente providencial e fundado em um paradigma cósmico. Ou seja, o mundo, locus do governo, é uma máquina cujas relações entre seus diversos elementos é operada pela providência cósmica e, enquanto o homem fizer o que lhe é conveniente, ou seja, seu officium, seu dever, esta máquina funcionará bem (AGAMBEN, 201 1, p. 42). Kant segue esta tradição de mecanicismo ético, encimandoo, no entanto, com o contratualismo. Enquanto Aristóteles coroava a estrutura do poder com uma figura ético-metafísica (a ordem que tendia para a eudaimonia como determinante do governo da política) e enquanto os estóicos tinham um projeto de moral individual fundado no atingimento da ataraxia, Kant une, de certa forma, os dois, esvaziando-os, no entanto, de seus caráteres ontológicos mais complexos, criando uma ontologia reificada e uma ética deontológica assombrada pela vaga noção de respeito.

A sua distinção entre autonomia e heteronomia, é, portanto, inútil e/ou falsa. Não cabe aqui afirmar que ela é falsa, vez que não foi o foco desta pesquisa. No entanto, para um conceito filosófico se afirmar, ele deve ser útil, vez que, se não é útil, a distinção que lhe transforma em um conceito autônomo é falsa. A necessidade na filosofia, é de expressar o real, e se o real puder ser expresso com outras palavras, é porque a distinção entre os vocábulos não existe (ou ainda é imprecisa). Mas por que se afirma isso de um conceito tão caro ao direito? $\mathrm{O}$ grande problema da autonomia kantiana é que ela é livre para tudo, menos para seguir outro caminho que não o do dever, segundo a regra de ouro kantiana. Em qualquer circunstância, esta ideia kantiana se realiza na supressão da busca existencial por expressão política (a não ser que o sujeito tenha o mesmo instrumental epistemológico e ético kantiano), mas a sociedade ocidental democrática liberal contemporânea já está suficientemente funcionalizada para crer que a discussão deve sair em absoluto da política e partir para o governo. Não mais "o que fazer", mas "como fazer".

Não foi sempre assim. Este processo estudado até aqui filosoficamente encontrou resistências teóricas e 
concretas, que precisavam ser, e foram, com maior ou menor grau de sucesso, superadas. O estudo que se iniciará a seguir é mais abrangente do que o feito até aqui, porque o que interessa é justo mostrar o que havia antes e que acabou por ser destruído ou incorporado. Não se partirá, no entanto, sem a extração de algumas conclusões preliminares.

\section{FORMANDO UM JUÍZO SOBRE KANT}

Não se propôs aqui reconstruir a formação do pensamento jurídico moderno, mas tão somente explicitar estas fontes que constituem a suprareferida paisagem, bem como as intenções de alguns de seus artífices. A obra de Michel Villey, como é notável, é a referência maior para o tema, e apresenta uma visão bem mais ampla sobre o tema. Em filosofia, política e do Direito, crê-se ter abordado de forma sucinta o que importa: o impacto do nominalismo, do protestantismo e do neoestoicismo na redefinição das relações jurídico-políticas entre os homens, que até hoje é corrente e que, no âmbito deste trabalho, é o que importa, e isso em uma perspectiva tanto institucional quanto comunitária.

Na primeira fase da modernidade, então, com a conformação de uma concepção de Direito Natural nova, racional, desenvolve-se uma doutrina do dever através de uma reflexão sobre a natureza humana, que, neste caso, significa exclusivamente a natureza racional. Esta doutrina, no entanto, é obscurecida pela afirmação dos direitos subjetivos, doutrina de origem nominalista, subterfugiados sob a efígie de direitos naturais - cujo grande destaque é o pensamento de John Locke. Assim, os deveres, objeto de reflexão tão querido dos neoestóicos, dos humanistas e da de uma certa escola que se poderia afirmar continental (ainda que o nominalismo que os influenciou tenha tido seus maiores nomes nascidos em berços insulares) foram relegados a contraparte esquecida dos direitos subjetivos. Começava, na Europa, a luta contra os governos autocráticos depois de séculos de centralização e crescimento do poder do soberano, e a Inglaterra saíra na frente, o Direito, a Filosofia e a Política outras armas neste confronto.

O próprio estoicismo, afirma MacIntyre, tinha a dimensão política provocadora do sistema e Adam Smith, um convicto neoestoicista, "foi um republicano por toda sua vida. E a conexão entre a preocupação de Smith com a virtude e seu republicanismo não era algo peculiar a seu próprio pensamento. O republicanismo no século XVIII éo projeto de restabelecer uma comunidade de virtudes; mas esse projeto é vislumbrado em um idioma herdado de fontes romanas e não gregas e transmitido através das repúblicas italianas da Idade Média." (MACINTYRE, 2007, p. 236) As repúblicas italianas da Idade Média, por sua vez, não foram o palco do desenvolvimento da democracia moderna, mas de um republicanismo maculado por disputas de poder de caráter profundamente demagógico e carente da noção de bem comum transcendental que caracteriza as sociedades que 
não consideram a democracia como mero procedimento. ${ }^{147}$

Estes autores, por afinidade de forma de pensar, retornavam a Maquiavel:

com sua exaltação da virtude cívica sobre as virtudes cristãs e pagãs, [Maquiavel] articula um aspecto da tradição republicana, mas apenas um. O que é central nessa tradição é a noção de um bem público que é anterior e caracterizável independentemente dos desejos e interesses individuais quando contemplados como um todo. Virtude no indivíduo não é nada mais nada menos que permitir que o bem público forneça o padrão para o comportamento individual. As virtudes são aquelas disposições que sustentam essa lealdade primordial. Daí o republicanismo, como o estoicismo, torna a virtude primária e as virtudes secundárias. A conexão entre o republicanismo do século XVIII e o estoicismo do século XVIII é frouxa; Muitos estóicos não eram republicanos - [...] - e muitos republicanos não eram estóicos. Mas eles compartilham um idioma, usam recursos do mesmo vocabulário moral, e não é surpreendente quando encontramos alguém como Adam Smith que compartilha ambas as lealdades. ${ }^{148} 149150$

As declarações de Direitos da "Era das Revoluções" foram silentes quanto aos Deveres. Ou melhor, não totalmente silentes, mas optaram por não darem a eles a mesma estatura que deram aos Direitos. Cabe pontuar que proposta de confecção de uma carta exclusiva de Deveres do Cidadão foi realizada na Assembleia Nacional

${ }^{147}$ MacIntyre relaciona Bismarck, Clausewitz e Maquiavel (in MACINTYRE. Alasdair. After Virtue: A Study in Moral Theory. Notre Dame: University of Notre Dame Press, 3 Ed., 2007, p. 10). Bismarck é relacionado por Villey também a Lutero, como já visto. O que Bismarck encarna, para ambos, é uma política centrada unicamente no fortalecimento da autoridade, suportada por razões de Estado de caráter amoral, relacionadas a expedientes argumentativamente trabalhados a partir do conceito de "ordem pública" e relacionados.

${ }^{148}$ MACINTYRE. Alasdair. After Virtue: A Study in Moral Theory. Notre Dame: University of Notre Dame Press, 3 Ed., 2007 , p. 236. Ainda: "O republicanismo, portanto, representa uma tentativa de uma restauração parcial do que eu chamei de tradição clássica. Mas ela entra no mundo moderno sem nenhuma das duas grandes características negativas que tiveram tanto a ver com o descrédito da tradição clássica durante o renascimento e no início do período moderno. Como eu acabo de notar, ele não falava em um idioma aristotélico e, portanto, não carregava o peso de uma aparente aliança com uma versão derrotada da ciência natural. E, ademais, ele não foi desfigurado pelo patrocínio daqueles despotismos absolutos, tanto no estado como na igreja, que, ao mesmo tempo em que destruíram a herança medieval, tentavam vestir-se na linguagem da tradição, inventando doutrinas tais como aquela perversão dos séculos XVI e XVII, a doutrina do direito divino absoluto dos reis. O republicanismo, por sua vez, herdou das instituições da república medieval e do renascimento aquilo que, em suma, que constituía uma paixão pela igualdade. 'O ethos da corporação', Gene Brucker escreveu, 'era fundamentalmente igualitário. Assumiu-se que os membros da guilda, da sociedade política (parte) ou das milícias (gonfalone) possuíam direitos e privilégios iguais e assumiam iguais obrigações para com a sociedade e seus companheiros' (Brucker 1977, p. 15) A igualdade de tratamento que os homens desfrutavam era o terreno propício para a virtude ser vista como a prestação de serviços à comunidade. É por isso que a concepção republicana de justiça é definida primariamente em termos de igualdade, mas secundariamente em termos de merecimento, de mérito público [...]”

${ }^{149}$ MacIntyre afirma a ausência de significado da democracia desta espécie de comunidade, ao verificar a instrumentalização do conceito de virtudes no contexto das cidades italianas em torno das condições destas cidades face as suas rivais em termos militares ou econômicos. Assim, inexistam: um pacto político em torno de um bem comum previamente definido (vez que o bem comum dependia de circunstâncias materiais transitórias da cidade); e, consequentemente, um conceito de virtude pública que pudesse ser perseguido constantemente (sem se alterar) sem ofensa às virtudes que o indivíduo professava como adequadas e praticava em sua vida privada. O indivíduo, em suma, era visto a partir da visão de súdito, apesar de ser chamado de cidadão, porquanto só servia tanto quanto se conformasse ao que a autoridade dele esperava. Esta forma de pensar encontra uma forma mais graciosa na fala do presidente norte-americano John F. Kennedy, ao, em discurso, afirmar: "ask not what your country can do for you, ask what you can do for your country" (tradução: "não pergunte o que o seu país pode fazer por você, mas o que você pode fazer por seu país.").

${ }^{150}$ MacIntyre relembra, nesta grande genealogia que aqui se traça, do kantismo e da relação entre homem e autoridade política, que "[A] virtude aristotélica da amizade e o amor cristão ao próximo contribuíram, no século XVIII, para a formação do conceito da recém-nomeada virtude da fraternidade. E o conceito republicano de liberdade era cristão também: 'Cui servire est regnare', diz a oração sobre Deus, ou como a versão em inglês diz, 'para quem servir é a liberdade perfeita', e o que o cristão disse sobre Deus, o 
Francesa em 1789, proposta esta que foi negada, com o argumento de que, "numa comunidade liberal, os deveres se identificam com os direitos".

Nas diversas declarações que surgiram pelo mundo neste período, porém, alguns deveres subsistiram, fossem de não opor resistência a lei, de pagar impostos, de servir nas forças armadas quando necessário, etc... ${ }^{151}$ De uma forma geral, esta forma de redação constitucional propriamente liberal perdurou até o fim da Primeira Guerra Mundial. Nos Estados belicosos, houve uma cada vez maior interferência da autoridade governamental na economia durante este período e, influenciadas por governos majoritariamente socialistas, surgiram Constituições (Mexicana, de 1917, e Alemã, de 1919) que renovavam a face da concepção dos direitos imanentes à definição de ser humano, os direitos sociais. Estes direitos são chamados de Direitos de Segunda Geração, na análise feita pelos Direitos Humanos da matéria.

Conforme dito, a partir da década de 70 do século XX, houve uma redescoberta da ética kantiana, cuja história ainda se está por escrever. Fato é que Kant se afirmou enquanto filósofo principal do Direito nas democracias liberais, principalmente através do trabalho de John Rawls. Otfried Höffe vê na obra de Habermas um primeiro momento de grande protagonismo kantiano, relacionado ao abandono da tradicional aspiração da Teoria Crítica por uma premissa absoluta e à consequente diminuição da importância (o que não significa perda aqui, mas muito mais uma saída para os bastidores) dos sistemas hegeliano e marxista, citando trabalhos como o artigo Philosophy as Placeholder and Interprete, ${ }^{I 52}$ Moral Conciousness and Communicative Action e Between Facts and Norms. O foco de Habermas é a reabilitação de uma filosofia moral em geral e do imperativo categórico em particular, a superação de qualquer restrição a estes e a construção de uma teoria da Lei e do Estado que, diversamente do que vinha sendo feito pela Teoria Crítica com base em Hegel e Marx, fosse compatível com a democracia constitucional moderna (HÖFFE, 2002, 249).

O caminho, no entanto, não foi fácil. Segundo Höffe:

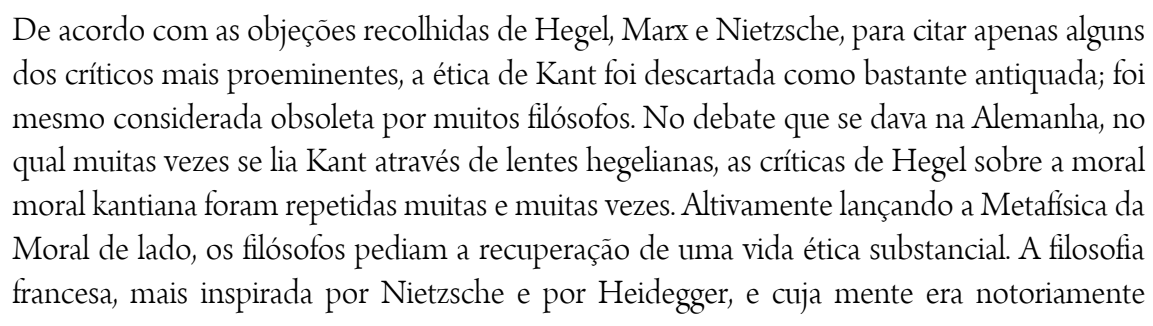

republicano diz da república." in MACINTYRE, Alasdair. After Virtue: A Study in Moral Theory. Notre Dame: University of Notre Dame Press, 3 Ed., 2007, p. 237.

${ }^{151}$ A Constituição Portuguesa de 1822 é um exemplo neste sentido. Seu Título I ostentava os dizeres "dos direitos e deveres individuais dos Portugueses" e prescrevia Deveres que, ainda assim, não extrapolavam, segundo Casalta Nabais, a esfera dos Deveres Morais ou qualquer coisa que pudesse ser concebida como Virtude Cívica, constitui hoje um dos marcos históricos mais importantes da disciplina dos Deveres Fundamentais. (NABAIS, José Casalta. O dever fundamental de pagar impostos. Coimbra: Livraria Almedina, 1998, p. 47).

${ }^{152}$ Os nomes são citados em inglês por esta ser uma língua mais acessível que o original alemão habermasiano. Isso se faz em razão da premente necessidade de uma história da virada kantiana. 
fechada à ética, corroborava de maneira lapidária: nada é mais estranho para nós do que um imperativo categórico. Há algum tempo, no entanto, uma forte contracorrente tem sido evidenciada. John Rawls, com sua 'interpretação kantiana da justiça', introduziu, como é sabido, uma nova tendência para o mundo de língua inglesa. E depois da Escola de Erlangen, no contexto de suas preocupações sistemáticas, desenvolver um interesse pela ética de Kant, propositores da ética do discurso, sobretudo Karl-Otto Apel e Jürgen Habermas, passaram recentemente a recorrer a Kant quando tiveram que enfrentar questões sistêmicas. A posição de Kant se mostra hoje, uma vez mais, como uma abordagem da filosofia moral que precisa ser levada a sério. (HÖFFE, 2002, 198)

Não é possível, portanto, desconsiderar Rawls, que precedeu Habermas, nesta recuperação.

Em uma série de ensaios escritos no final dos anos 70 e 80, Rawls explicitou mais profundamente as intuições kantianas mais profundas que guiaram a construção de sua teoria da justiça, especialmente seus componentes mais igualitários. A Theory of Justice (1971), Rawls afirmava, não tinha sido uma tentativa de desenvolver princípios normativos substantivos a partir de um modelo de racionalidade puramente neutro, teorístico, como muitos tinham suposto. Pelo contrário, a idéia fundamental de uma pessoa dotada de dois poderes morais básicos - os quais Rawls chamou de Racional e Razonável - constituía o aspecto kantiano mais profundo de sua teoria. A seleção dos princípios da justiça e o desenho da estrutura básica da sociedade devem refletir e garantir igualmente para todos esses poderes morais básicos da pessoa. No entanto, pelo menos em parte em resposta a críticas comunitaristas, como as de Michael Sandel, que argumentou que a concepção kantiana da pessoa era abstrata e desencarnada - "um sujeito livre de compromissos de posse” - Rawls, a partir de meados dos anos 80, começou a mudar a direção de seu argumento, fazendo-o depender mais fortemente nas idéias latentes em nossa cultura política liberal. A estratégia era, por assim dizer, afastar a objeção comunitária alegando que sua teoria não dependia de quaisquer pressupostos "metafísicos" sobre a pessoa ou de qualquer coisa da espécie, mas poderia ser desenvolvido a partir das idéias compartilhadas por todos os liberais, quer fossem individualistas kantianos ou não.

Höffe, é importante afirmar, já escreveu sobre Rawls. No entanto, a rejeição deste autor americano da metafísica kantiana (grande parte desta rejeição está contida na primeira conferência de seu Liberalismo Político) afasta os dois autores em razão da diferença de focos temáticos: enquanto Höffe foca mais na (de)ontologia kantiana e em outros aspectos de sua metafísica, Rawls foca mais nas conclusões políticas de Kant, negando a necessidade de adoção desta metafísica (ou de qualquer outra, a bem da verdade - seu conceito de justiça, afinal, é político, e não metafísico) para a construção do consenso social que é seu objeto de estudo. ${ }^{153}$

Kant era filho de um Estado autoritário (Prússia, posteriormente Império Alemão), e isso explica a sua filosofia política cosmopolita de forma inegável, vez que até o termo que utiliza é próprio do estoicismo, ${ }^{154}$ que nasce em circunstâncias semelhantes (de autoritarismo político e de esvaziamento da discussão política pública pela repressão). Para Kant, não se trata de atingir um sentido na comunidade política existente. O sentido já existe, já foi descoberto em sua metafísica dos costumes, e ele se afirma na extensão jurídica dos postulados morais de

\footnotetext{
${ }^{153}$ HÖFFE, Otfried. Categorical Principles of Law: A Counterpoint to Modernity. University Park: The Pennsylvania State University Press, 2002, p. VIII (do Prefácio de Kenneth Baynes). Kenneth inclusive sugere o encontro de Rawls com dificuldades que, insinua, não conseguiu superar, em razão de sua "justiça como equidade”.

${ }^{154}$ Kant se afirmava o maior herdeiro moderno dos estóicos, segundo MacIntyre In MACINTYRE, Alasdair. After Virtue: A Study in Moral Theory. Notre Dame: University of Notre Dame Press, 3 Ed., 2007, p. 236.
} 
igualdade e liberdade, decorrentes da dignidade intrínseca ao homem. Discursivamente, a universalização destes direitos parece ser a última proposta política. Mas o quanto seu universalismo, ampliação do consenso ético de uma pequena quantidade de cidadãos não fecha a política enquanto discurso do possível para o homem, ou seja, não tolhe a imaginação política? "Se a política é necessariamente a celebração destes valores, o que mais se pode fazer politicamente que não seja tão somente ampliar o alcance destes valores e a intensidade de sua penetração da vida diária?" Devolve a pergunta Kant, em sua teoria jurídica e política, que são indissociáveis, e temerariamente se poderia dizer mesmo indistintas, de sua ética e de sua metafísica e todas, por sua vez, intrinsecamente vinculadas a sua ontologia (se é que pode se falar de uma) e de sua epistemologia. Kant prega um mundo de uma liberdade extremamente limitada pelas máximas de seus imperativos categóricos.

E não se trata de discordar aqui substancialmente deles. A questão é propriamente filosófica, porque Kant se utiliza de postulados de uma doutrina moral (estoicismo), amplia-os para uma doutrina política (com consequências que têm paralelo na realidade prática do conceito de Império Universal romano) e, ao mesmo tempo, esvazia o sentido metafísico (ataraxia) desta doutrina, substituindo-o por outro (o que também tinha certo paralelo no próprio ecletismo de Cícero, apesar do senador romano tê-lo feito de forma diferente). Qual é o sentido metafísico que Kant utiliza para preencher seu neoestoicismo? O dever religioso, ${ }^{155}$ como apontado por

\footnotetext{
${ }^{155}$ Schopenhauer, que "havia dedicado à genealogia do dever um capítulo do escrito de 1840, 'Über die Grundlage der Moral' [Sobre o fundamento da moral] é quem o diz, sob a rubrica 'Von der imperativen Form der kantischen Ethik' ['Sobre a forma imperativa da ética kantiana']. [...] Segundo Schopenhauer, o imperativo teológico, que tinha sentido somente em vista de uma punição ou de um prêmio e não podia ser separado destes, foi sub-repticiamente transferido por Kant para a filosofia, onde assumiu a forma contraditória de um 'dever absoluto ou categórico'. Enquanto a moral kantiana se funda, nesse sentido, sobre 'pressupostos teológicos escondidos' - é, na verdade, uma 'teologia moral' (Moraltheologie) -, pode-se dizer que ela produziu 'um resultado do que deveria ser o princípio ou a premissa (a teologia), e [...] por premissa o que deveria ser inferido como resultado (o comando)'” Assim, "o 'conceito fundamental da ética kantiana, o dever: 'a necessidade de uma ação por respeito à lei' [die Nothwendigkeit einer Handlung, aus Achtung vor dem Gesetz]'” Isso, nas palavras de Agamben, nada mais seria que "a transcrição 'artificialmente escondida e um tanto forçada' da palavra 'deve' (soll), que, como tal, remete à língua do Decálogo.” Logo, a proposição “dever é a necessidade de uma ação com respeito à lei” significa, na verdade, "dever é uma ação que deve ocorrer por obediência [aus Gehorsam] com respeito a uma lei’. Agamben complementa: 'A genealogia esboçada por Schopenhauer, muito provavelmente correta, mostra quão pouco é feito quando se retira a máscara de algo, colocando-lhe a nu a origem escondida. Reportando a ética kantiana a seu pressuposto teológico não se ganha muito, de fato, quanto ao que deveria interessar em primeiro lugar, isto é, à compreensão do paradigma prático que ela produziu e à estrutura e às características específicas da ação humana que nela está em questão. Como Foucault havia sugerido, fazer uma genealogia não significa 'retirar todas as máscaras, para desvelar finalmente uma identidade primeira'; significa, antes, através de uma análise minuciosa dos detalhes e dos episódios, das estratégias e das táticas, das mentiras e das verdades, dos détours e das vias principais, das práticas e dos saberes, tentar substituir, no caso que nos interessa, a pergunta previsível 'qual é a origem da ideia de dever?' pelas assaz menos óbvias “o que está em jogo na estratégia que leva a conceber a ação humana como um officium?’ e 'qual é a natureza de um ato litúrgico, ou seja, de um ato que se deixa definir integralmente em termos de officium?". Todas as explicações aqui contidas foram retiradas de AGAMBEN, Giorgio, Opus Dei: Arqueologia do Ofício. São Paulo: Boitempo Editorial, 2013. P. 95/6. As reflexões até agora feitas neste seção tinham um caráter preparatório da desconstrução do conceito de dever como paradigma científico da estruturação das relações entre Estado (de Direito) e cidadão. Mesmo na epistemologia kantiana acredita-se ser possível verificar traços de protestantismo. Este trecho, de Weber, explicando a incognoscibilidade de Deus e de Seus desígnios pelo homem relembra a própria epistemologia kantiana, fundada na incognoscibilidade do real pelo homem: "Pois tudo da carne está separado de Deus por um abismo intransponível e Dele não merece senão a morte eterna, a menos que Ele, para a glorificação de Sua majestade, tenha decidido de outra forma. De uma coisa apenas sabemos: que uma parte dos seres humanos está salva, a outra ficará condenada. Supor que mérito humano ou
} 
Schopenhauer, que funciona como dobradiça da porta entre as máximas de sua metafísica e a prática ética, política e jurídica que delas extrai. Mas mesmo as máximas de seus imperativos categóricos tem um claro caráter religioso, apesar deste caráter não ser intrínseco e ele poder ter extraído o sentido que as preenche do próprio estoicismo que também é forte fonte de inspiração.

Existente esta dúvida, tende-se a crer que a influência é mútua, com base em cartas e trabalhos que depõe neste sentido, além de ser esta a opinião geral dos autores, conforme exposto acima. Em Kant, o estoicismo reforçou o aspecto deontológico que o protestantismo busca no judaísmo, ${ }^{156}$ ao mesmo tempo que a seita

culpa humana contribuam para fixar esse destino significaria encarar as decisões absolutamente livres de Deus, firmadas desde a eternidade, como passíveis de alteração por obra humana: ideia impossível. Do 'Pai que está no céu', mostrado pelo Novo Testamento de forma acessível à compreensão humana, o qual se alegra com o regresso do pecador feito a mulher que acha a moeda que havia perdido, deu lugar aqui a um Ser transcendente que escapa a toda compreensão humana e que, desde a eternidade, por decretos de todo insondáveis, fixa o destino de cada indivíduo e dispõe cada detalhe no cosmos. Uma vez estabelecido que seus decretos são imutáveis, a graça de Deus é tão imperdível por aqueles a quem foi concedida como inacessível àqueles a quem foi recusada." Se esta, por certo, não é uma prova irrefutável, deve-se, em primeiro lugar, correlacionar esta interpretação bíblica com a filosofia jusnaturalista neoestóica e racionalista que vinha sendo feita, a qual Kant leu e que, na maior parte das vezes, foi elaborada por pessoas que ouviram esta espécie de discurso teológico durante parte, ao menos, da vida, e a submissão do próprio Kant a esta espécie de discurso, ao menos durante sua infância. $\mathrm{O}$ trecho selecionado, com pequenas alterações baseadas na tradução de Talcott Parsons (p. 60) in WEBER, Max. A ética protestante e o "espírito" do capitalismo. São Paulo: Editora Schwarcz Ltda. 2007, p. 94.

${ }^{156}$ Sobre as diferenças entre o protestantismo reformado e o judaísmo, interessante análise de Weber: "Os puritanos reprovaram os apócrifos por não inspirados, consoante sua rígida alternativa ou entre o que é de Deus e o que é da criatura. Tanto mais influente dentre os livros canônicos foi o Livro de Jó, que combina uma celebração grandiloqüente da majestade absolutamente soberana de Deus pairando muito acima dos padrões humanos — o que, convenhamos, era totalmente congenial às concepções calvinistas com aquela certeza, que rebenta novamente no desfecho do livro, de que Deus costuma abençoar os seus também e até mesmo [no Livro de Jó: - somente!] nesta vida, incluindo aí o aspecto material, idéia tão secundária para Calvino quanto relevante para o puritanismo. O quietismo oriental, patente em alguns dos versículos mais inspirados dos Salmos e dos Provérbios de Salomão, foi ignorado, a exemplo do que fez Baxter com o tom tradicionalista da passagem da $1^{\text {a }}$ Epístola aos Coríntios que entrou na constituição do conceito de vocação profissional. Em contrapartida, ênfase tanto maior era dada às passagens do Antigo Testamento que louvam a justeza formal como marca distintiva da conduta agradável a Deus. A teoria segundo a qual a Lei mosaica foi despojada de sua validade pela nova aliança apenas na medida em que continha prescrições ou de cunho ritual para o povo hebreu ou que eram historicamente condicionadas, mas no fim das contas mantinha a validade que possuía desde sempre enquanto expressão da lex naturae e por isso ainda vigente, possibilitou por um lado a eliminação daquelas prescrições desde logo incapazes de se encaixar na vida moderna enquanto, por outro lado, os incontáveis traços de parentesco com a moralidade do Antigo Testamento desimpediam os trilhos paru um vigoroso fortalecimento daquele espírito de legalidade sóbria e autocorretiva que era próprio da ascese intramundana desse protestantismo. Se, portanto, como muitas vezes já os contemporâneos e assim também escritores recentes usam para designar a disposição ética fundamenta] específica do puritanismo inglês a expressão 'English Hebraism', ela é, se corretamente entendida, de todo pertinente. Só não se há de pensar no judaísmo palestino da época em que surgiram os escritos do Antigo Testamento, mas no judaísmo tal como se plasmou gradualmente sob o influxo de muitos séculos de educação legal-formalista e talmúdica [e mesmo então é preciso ter muita cautela com paralelos]. A disposição do judaísmo antigo para a espontânea valorização da vida como tal estava a léguas de distância da peculiaridade específica do puritanismo. [igualmente distante - e isso também não pode passar despercebido - estava a ética econômica do judaísmo medieval e moderno no que tange aos traços decisivos para a posição de um e outro no bojo do desenvolvimento do ethos capitalista. O judaísmo postava-se ao lado do capitalismo 'aventureiro' politicamente orientado ou de orientação especulativa: seu ethos, numa palavra, era o do capitalismo-pária - ao passo que o puritanismo portava em si o ethos da empresa racional burguesa e da organização racional do trabalho. Tomou da ética judaica só o que cabia nesses horizontes.]" in WEBER, Max. A ética protestante e o "espírito" do capitalismo. São Paulo: Editora Schwarcz Ltda. 2007, p. 149. Se de fato o pietismo tinha um caráter mais livre ética e emocionalmente, como afirma Weber, e de fato este pendor comercial seja ausente na obra de Kant, a forma de pensar a justeza, esvaziada de joie de vivre, e não necessariamente em um sentido festivo, mais mesmo teleológico - a vida para a ética kantiana é tão formalizada que se questiona o porquê de, politicamente, Kant se esforçar para torna-la tão menos supressora, e 
específica de protestantismo no seio da qual foi criado, a pietista, ${ }^{157}$ propicia-lhe o messianismo, como é fácil de se constatar em obras como A Paz Perpétua, de significativa influência para a retomada dos estudos jurídicos de Kant. Seu mundo político não é o de uma comunidade que se une para buscar soluções para seus problemas, mas o de uma comunidade que busca tão somente aplicar as soluções que já tem, das quais são simplesmente extraídos os princípios que as justificam. ${ }^{158}$ A liberdade em Kant é uma liberdade privada tão somente, verdadeira liberdade dosmodernos.

A filosofia kantiana é não só reflexo dos elementos estudados como definidores do pensamento jurídico moderno, mas uma verdadeira celebração de uma de suas vertentes, tendo atingido, na opinião de autores como Agamben, o ápice nesta área. Austera, racionalista e idealista. Aqueles que a seguem devem ter plena consciência de seus anacronismos, de sua oposição à valoração fática do mundo, de sua ode ao Dever. ${ }^{159}$ Encontrar uma ética

ainda mais se utilizando de um deus ex machina como a dignidade humana - é a mesma forma de pensar de um puritano. Nenhuma surpresa que sua filosofia faça ainda sucesso em um mundo que é basicamente, se não criado sozinho pela Reforma, ao menos educado em seus ideais. Ademais, também não é impressionante que a filosofia idealista alemã, da qual Kant é um exemplo, ainda que controverso, não seja a grande força motora intelectual nos países anglo-saxônicos. Weber, neste trecho, deixa muito claro que, apesar de muitas semelhanças, o puritanismo - esta sim a vertente do protestantismo que conquistou Inglaterra e América - tem este forte viés comercialista, materialista, e as consequências dessa educação no concreto podem ser vistas na tendência inegável da filosofia inglesa para o empirismo e para o utilitarismo. A justeza formal, a qual Weber se refere, é o traço comum de ambos, e mesmo as apropriações filosóficas de Kant na América, como a feita por Rawls, renegam sua metafísica, profundamente idealista. O pietismo, por ser bem caracteristicamente uma seita, combinava elementos luteranos e reformados, e é claro que nem tudo se pode atribuir a ele - foram estudadas, afinal, só neste trabalho, outras duas influências na formação do pensamento kantiano - mas ele serve, como toda religião, para preparar o terreno intelectual e torna-lo mais propício à frutificação de certas ideias e menos propício a outras. Esta desconfiança da razão-quando-utilizada-para-buscar-otelos-das-coisas, típica do protestantismo, também é vista em Kant e em todos os filósofos com background protestante, como já foi exposto - a razão só pode se pensar e calcular e, nestes campos ela é, em compensação, absoluta.

${ }^{157}$ Weber, no entanto, ressalta que o elemento racional e ascético prevalecia sobre o emotivo no pietismo (p.84). Ademais o próprio elemento emotivo vai aos pouco sendo mitigado. Diz Weber: "Devemos voltar a lembrar-nos de que este pietismo emocional, naturalmente, se sombreia no caminho da vida dos eleitos puritanos por etapas bastante graduais. Se pudermos, pelo menos provisoriamente, apontar qualquer conseqüência prática da diferença, podemos dizer que as virtudes favoritas do pietismo eram mais, por um lado, as dos oficiais, servidores, operários e trabalhadores que produzem em domicílio "fiéis à sua profissão" e do outro, empregadores de conformação preponderantemente patriarcal, ostentando sua condescendência a fim de agradar a Deus (à maneira dr Zinzendorf). O calvinismo, em comparação, parece ter mais afinidade eletiva com o rígido senso jurídico e ativo do empresário capitalista-burguês." in WEBER, Max. The Protestant Ethic and The Spirit of Capitalism. Nova Iorque: Routledge, 2005 , p. 88.

${ }^{158}$ Essa é uma das razões para a metafísica kantiana ser tão pobre, como apontado por Agamben. Para uma crítica da instrumentalização do conceito de imperativo categórico, ver MACINTYRE, Alasdair. After Virtue: A Study in Moral Theory. Notre Dame: University of Notre Dame Press, 3 Ed., 2007, cap. 5, especialmente entre as págs. 54-60, e cap. 4, principalmente, entre as págs. $41 / 6$.

159 “Dever! — Nome sublime e grande, tu que não encerras nada amável que leve consigo alguma insinuante lisonja, mas que pedes submissão, sem contudo ameaçar com algo que desperte natural aversão no ânimo, atemorizando-o para mover a vontade, tu que só exiges uma lei que por si mesmo encontra acesso ao ânimo e que, não abstante, conquista, ainda mesmo contra a nossa vontade, veneração por si mesma (embora nem sempre a observemos); tu, ante quem emudecem todas as inclinações, mesmo quando agem secretamente contra ti — qual é a origem digna de ti? Onde se encontra a razão de tua nobre ascendência, que repele orgulhosamente todo o parentesco com as inclinações, essa raiz da qual é condição necessária que proceda aquele valor que só os homens podem dar a si mesmos?" (Capítulo III, Livro I, Primeira parte, Crítica da Razão Prática in http://www.ensinarfilosofia.com.br/__pdfs/e_livors/46.pdf). Nietzsche afirma: "O problema: Deve! Uma inclinação que não consegue dar fundamento a si mesma, similar nisso ao instinto sexual, não cairia sob a condenação dos instintos, mas seria, ao contrário, o critério de valor e o juiz" (NIETZSCHE, Friedrich. Opere: Frammenti postumi, 1885-1887 (orgs. Giorgio Colli e 
kantiana vinculada a um instituto chamado Dever Fundamental é adequado. Crer que isso possa significar qualquer valoração prática para além de uma valoração estritamente racional, como os pós-positivistas pretendem, já parece impossível. A ética kantiana não é uma ética, ou seja, um hábito, uma prática, mas um exercício intelectual onde se buscam respostas certas pré-determinadas, ainda que desconhecidas (o que, aliás, diz Villey sobre o próprio estoicismo).

Este parece ser o maior problema dos pós-positivistas, querer achar valores materiais onde não há. No caso da utilização do kantismo na obra Dever Fundamental de Pagar Impostos, que foi apontada como exemplo, até pode haver justificação kantiana, haja ver a prescindibilidade de justificação da tese desenvolvida pelo autor, que joga irresponsavelmente com conceitos que inevitavelmente serão utilizados por intelectuais contrários a sua própria posição, realmente liberal, como foram utilizados, no Brasil mesmo, por doutrinadores de grande renome, como Ricardo Lobo Torres que desvinculou a tese de Casalta Nabais enquanto instrumento de suas circunstâncias como fez com Kant.

Kant era, ademais, um contratualista. O contratualismo, que não foi abordado neste trabalho devido ao corte histórico (e epistemológico, de certa forma) feito, é a tese filosófica de que em algum momento ahistórico houve a fundação do Estado através da celebração de um Contrato Social. Este contrato estabelecia os direitos e deveres do cidadão ou dos súditos em relação aos seus pares e em relação ao Estado. O contratualismo surgiu como uma forma de renovar a doutrina do Direito Natural no séc. XVIII, que havia sido, por sua vez, também renovada na reflexão religiosa da escolástica dos sécs. XVI e XVII, e que, antes, buscou sagrar-se de um racionalismo humanista. O Direito Natural humanista, o jusracionalismo, tem sido, desde então, apesar das críticas, a ética fundamental do Ocidente. Ele só tem um problema. Um de seus elementos mais significativos, justo o contratualismo, não é real, mesmo quando considerado como hipótese.

Os estudos históricos têm reiteradamente provado que uma análise atomista do ser humano é impossível (e aqui só se traz este ponto para aqueles que defendem uma visão radical de Locke em seus Two Treatises of Government). Ademais, a leitura que se costuma fazer dos clássicos da filosofia política dos sécs. XVII-XVIII é amputada pela falta de adequação dos termos e ideias às circunstâncias nas quais eles foram gerados e utilizados, quando há uma leitura. A proposição de Hobbes, por exemplo, referida ao estado de natureza, o chamado estado de bellum omnium contra omnes, não se pretende uma possibilidade real arvorada pelo autor, como mostra Agamben. ${ }^{160}$

Mazzino Montinari). Milão; Adelphi, 1975, p. 151.) apud AGAMBEN, Giorgio, Opus Dei: Arqueologia do Ofício. São Paulo: Boitempo Editorial, 2013. P. 95/6.

${ }^{160}$ AGAMBEN, Giorgio. Homo Sacer: Sovereign Power and Bare Life. Standford: Stanford University Press, 1998, p. 27. Hobbes propõe que se pense em como seria a realidade se o Estado não existisse, como se seus poderes desaparecessem um por um da sociedade, para, então, afirmar que o que surge de forma discernível como o real poder do Estado reside na violência da qual ele se 
Mas o contratualismo, enquanto movimento filosófico situado em um certo momento específico, maior ou menor segundo o corte histórico de cada pesquisa (Rawls, por exemplo, se define como contratualista RAWLS, 2000, p. 12), na história da filosofia política tem outros problemas, enfrentados por autores, como Alasdair MacIntyre. Para ele, e para outros críticos que poderiam ser chamados de comunitaristas (e ele não é um comunitarista padrão), o problema do contratualismo é que, além da sua anacronia história, ele tende a ser totalmente vazio de conteúdo. É a crença de que um contrato estabelece os direitos e deveres de cidadãos ou súditos. O contratualismo não é individualista, no sentido original do termo, qual seja, de pôr o indivíduo como premissa de seus estudos sobre o contrato social, em regra, nem socialista, ou seja colocar a sociedade como premissa. Ele, enquanto movimento histórico, sempre depende de uma outra decisão metodológica, muitas vezes advinda de outra área do conhecimento filosófica, a ser feita por seus autores para poder se resolver. Os três grandes autores contratualistas, Hobbes, Locke e Rousseau, este último verdadeiro ídolo para Kant, ${ }^{161}$ discordavam totalmente entre si do teor do Contrato Social e da situação que levara os seres humanos a assiná-lo. E, obviamente, propunham três formas de Governo totalmente diversas.

Assim, para os comunitaristas, e para MacIntyre, especialmente, esta fragilidade do contratualismo constitui um problema epistemológico que, se submetido a uma análise mais profunda revela um vazio de sentido, fundado em uma aceitação de um senso comum ou de uma opinião pessoal como se fosse uma verdade universal, sem o rigor científico necessário para a propositura de uma hipótese adequada às premissas assumidas. Ou seja, o contratualista em questão afirma que vai pesquisar os termos e o caráter pré-contratual do contrato social, mas coincidentemente, estes termos e condições refletem uma visão ideológica do mundo, ${ }^{162}$ fundada ora em um incipiente liberalismo (Locke), ora em uma apropriação romântica de ideias religiosas (Rousseau ${ }^{163} \mathrm{e} \mathrm{Kant}^{164}$ ).

No final de seu A Ética Protestante e o Espírito do Capitalismo, Weber afirma que as conduta racionalizada, baseada no chamamento ao trabalho, enquanto faceta do Beruf,é de origem protestante, e mesmo a ascese típica da classe média de alguns países pode ser retraçada a esta origem religiosa, hoje esquecida, muitas

utiliza e a qual ele monopoliza. A partir desta conclusão extraída de sua hipótese é que seus raciocínio políticos partirão. Esta é sua premissa.

${ }^{161}$ E detentor em sua obra da mesma espécie de anacronismos deste. Ver cáps. V e VII da Parte II da op. cit. Fábio Konder Comparato.

${ }^{162}$ Este é o tema dos capítulos 4 (que tem caráter preparatório do tema) e 5 (onde a crítica é tecida de forma vigorosa) da obra citada de Alasdair MacIntyre.

${ }^{163}$ Como já visto, a obra de Agamben, o Reino e a Glória (The Kingdom and the Glory) trata deste tema em seu apêndice.

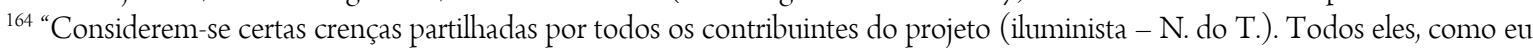
notei anteriormente, concordam de forma surpreendente com o conteúdo e o caráter dos preceitos que constituem a moralidade genuinamente. Casamento e família au fond não são questionados nem pelo philosophe racionalista de Diderot, nem pelo Juiz Wilhelm de Kierkegaard; o cumprimento do pactuado e o conceito de justiça são tão invioláveis para Kant quanto para Hume. A partir de onde, ou de quem ou de quando eles herdaram estas crenças comuns? Obviamente de seu passado cristão comum, contra cujas diferenças entre o luteranismo kantiano e kierkegaardiano, o presbiterianismo humiano e o catolicismo fortemente influenciado pelo jansenismo de Diderot não conseguiram prevalecer." (tradução livre) In MACINTYRE, Alasdair. After Virtue: A Study in Moral Theory. Notre Dame: University of Notre Dame Press, 3 Ed., 2007, p. 51. 
vezes, por aqueles mesmo que pregam este comportamento. Para além disso, o abandono do desejo de conhecimento/habilidade/técnica universal, com a adesão completa a uma atividade profissional bem específica, isso também vem do conceito de Berufe do providencialismo nele contido. Esta forma de vida, ou ausência de forma de vida, diz Weber, com o que se concorda, é também a renúncia a outras formas de vida. Por que?

É o próprio Weber quem afirma:

O puritano queria ser um profissional — nós devemos sê-lo. Pois a ascese, ao se transferir das celas dos mosteiros para a vida profissional, passou a dominar a moralidade intramundana e assim contribuiu [com sua parte] para edificar esse poderoso cosmos da ordem econômica moderna ligado aos pressupostos técnicos e econômicos da produção pela máquina, que hoje determina com pressão avassaladora o estilo de vida de todos os indivíduos que nascem dentro dessa engrenagem — não só dos economicamente ativos e talvez continue a determinar até que cesse de queimar a última porção de combustível fóssil.

A questão, e também o próprio Weber a traz, é que o puritano (e o protestante, de forma geral, conforme conclui o autor nesse estudo) queria existir em uma estrutura que permitisse a sua prática ética. O problema é que a engrenagem que esta prática ética ativou funciona dentro de uma máquina que não pode ser parada. Será visto mais à frente como ela funcionou na formação de Estados, e ela é, de certa forma, redutível a máxima da causalidade. Mas não é só.

Quando a prática da ascese intramundana está inserta dentro do sistema de crença dos puritanos, dos outros reformados ou mesmo dos luteranos, enfim, de qualquer seita protestante, ele faz sentido existencial para seu praticante. Ele está inserido numa lógica de comunidade, mesmo que não seja uma comunidade concreta, ou física. Mesmo o monge anacoreta fazia parte de uma comunidade, a comunidade dos santos, a Cidade de Deus. É para lá que se voltam os olhos do protestante isolado. Mas o resto do mundo, para quem a prática da ascese é imposta por mecanismos econômicos e, hoje mais do que à época de Weber, mas já naquele período, especificamente financeiros, apesar de ser forçado a agir de uma certa forma, padece de uma solidão absoluta. A solidão na multidão, conforme a interpretação de Benjamin do homem na massa de Baudelaire.

Há sempre uma tentativa de reabilitar o espírito que justifica a ascese, e aqui a questão não é só a ascese econômica, mas a ascese como dever - de trabalhar, de se manter dentro da lei, de não se pôr fora do sistema. $\mathrm{O}$ Iluminismo foi uma, diz Weber, hoje, no direito especificamente, se passa por outra. A tendência é que todas falhem. O positivismo tinha muitas vantagens. Uma delas era expor o funcionamento da máquina e, em última instância, mostrar que ela não tem nenhuma razão que não uma dada pelo indivíduo para funcionar. $O$ forte apelo da democracia reside aí, em dar a oportunidade que o indivíduo crie a razão para a máquina funcionar. O póspositivismo, com sua retórica kantiana, só reforça o dever de obedecer, como já foi mostrado, ao mesmo tempo que tira a oportunidade do homem de criar a razão para obedecer. O sucesso das comunidades protestantes é fundado na adesão, como já visto. 
A justificativa, no mundo fora da academia jurídica, para o funcionamento da máquina é o consumo, a alienação absoluta de uma vida vivida para a satisfação animal de impulsos irracionais de estímulos externos fundadas em apreciações superficiais da personalidade de cada indivíduo. Weber o diz. E ele vê que este esvaziamente metafísico leva inevitavelmente ao futuro maquínico previsto por Jünger e Heidegger, a uma sociedade absolutamente competitiva que se impõe mesmo às comunidades cooperativas protestantes originais como um legado definitivamente não desejado. Fachmenschen ohne Geist, Genußmenschen ohne Herz: dies Nichts bildet sich ein, eine nie vorher erreichte Stufe des Menschentums erstiegen zu haben. Especialistas sem espírito, sensualistas sem coração: essa Nulidade imagina ter chegado a um grau de civilização nunca antes alcançado. A frase, de Goethe, descreve, segundo Weber, a sua própria realidade.

Antes de terminar sua obra, Weber aponta outros culpados. O racionalismo ascético, e a significação que ele "teve para o conteúdo da ética político-social, ou seja, para o modo de organização e de funcionamento das comunidades sociais, desde o conventículo até o Estado"; "o racionalismo humanista e seus ideais de vida, suas influências culturais e, além disso, com o desenvolvimento do empirismo filosófico e científico, sua relação com o desenvolvimento técnico e com os bens culturais espirituais"; e o vir-a-ser histórico do protestantismo, "desde os primeiros ensaios medievais de uma ascese intramundana até a sua dissolução no puro utilitarismo, passando em revista cada uma das zonas de disseminação da religiosidade ascética." ${ }^{165}$ Foi um pouco isso que conduziu esta pesquisa até aqui. Viu-se os caminhos que foram percorridos para a construção de uma ética deontológica inexpugnável, bem como suas diversas versões, mais ou menos inexpugnáveis, conforme o talento de seus advogados, sendo Kant o maior deles, e seus desenvolvimento específicos através do tempo. Viu-se como ela penetra a doutrina jurídica brasileira hoje, em que momento, e em quais discursos históricos tenta se apoiar.

Não se quer dizer, porém, que o tema foi exaurido. Parece haver grande lacuna no desenvolvimento de pesquisas históricas genealógicas e arqueológicas em toda esta área de transição do pensamento jurídico e político para a modernidade, ${ }^{166} \mathrm{o}$ que inclusive forçou a utilização ostensiva de trabalhos com profundo caráter didático

\footnotetext{
${ }^{165}$ Os últimos quatro parágrafos foram escritos com base nos últimos dois parágrafos da obra de Weber. WEBER, Max. A ética protestante e o "espírito" do capitalismo. São Paulo: Editora Schwarcz Ltda. 2007, p. 164-7.

${ }^{166}$ Mas especialmente quando se trata do estudo de comunidades vocacionais não eclesiásticas, que parecem ter sido os gérmens da democracia moderna e nascem nesse contexto, mormente se as considerar enquanto processo de distinção política de um determinado grupo social em relação à tradição política europeia, encarnada na instituição estatal, processo este que encontra seu ápice na revolução americana. A fim de se esclarecer esta última frase, colaciona-se longa passagem de Deleuze: "O celibatário de Melville, Bartleby, como o de Kafka, deve encontrar o 'lugar de seus passeios', América. O americano é aquele que se libertou da função paterna inglesa, é o filho de um pai reduzido a migalhas, de todas as nações. Desde antes da independência, os americanos pensam na combinação dos Estados, na forma do Estado que seria compatível com sua vocação; mas sua vocação não consiste em reconstituir um 'velho segredo de Estado', uma nação, uma família, uma herança, um pai, mas, antes de tudo, em constituir um universo, uma sociedade de irmãos, uma federação de homens e de bens, uma comunidade de indivíduos anarquistas, inspirada em Jefferson, em Thoreau, em Melville. [...] em Redburn (Cap. 33): 'Não se pode verter uma única gota de sangue americano sem derramar o sangue do mundo inteiro. Inglês, francês, alemão, dinamarquês ou escocês, o europeu que zombar de um americano zomba de seu próprio irmão e põe em perigo sua alma para o dia do Juízo. Não somos uma raça estreita, uma tribo nacionalista e carola de hebreus, cujo sangue está abastardado por tê-lo querido demasiado puro mantendo uma descendência direta e
} 


\section{THE KANTIAN THEORY OF DUTY: THE ARCHEOLOGY OF A MORAL LANDSCAPE}

casamentos consanguíneos... Somos menos uma nação que um mundo, pois a menos que se chame, como Melquisedeque, o mundo inteiro de nosso pai, somos sem pai nem mãe... Somos os herdeiros de todos os séculos de todos os tempos, e nossa herança, nós a partilhamos com todas as nações...' [...] A América pensava estar fazendo uma revolução cuja força seria a imigração universal, os emigrados de todos os países, assim como a Rússia bolchevista acreditara estar fazendo uma, cuja força seria a proletarização universal, 'Proletários de todos os países...' duas formas da luta de classes. Desse modo, o messianismo do século XIX tem duas cabeças e se exprime tanto no pragmatismo americano como no socialismo finalmente russo. [...] para isso é preciso também que o sujeito conhecedor, o único proprietário, ceda o lugar a uma comunidade de exploradores, precisamente os irmãos do arquipélago, que substituem o conhecimento pela crença, ou antes, pela 'confiança': não crença num outro mundo, mas confiança neste mundo aqui, e tanto no homem como em Deus ('Vou tentar a ascensão de Ofo com a esperança, não com a fé... irei pelo meu caminho...'). [...].o que deve ser a comunidade dos homens para que a verdade seja possível? Truth e trust. $\mathrm{O}$ pragmatismo não cessará de lutar em duas frentes, como já Melville: contra as particularidades que opõem o homem ao homem e alimentam uma desconfiança irremediável, mas também contra o Universal ou o Todo, a fusão das almas em nome do grande amor ou da caridade. [...] Lawrence dizia ser esse o novo messianismo ou o aporte democrático da literatura americana: contra a moral europeia da salvação e da caridade, uma moral da vida em que a alma só se realiza tomando a estrada, sem outro objetivo, exposta a todos os contates, sem jamais tentar salvar outras almas, desviando-se das que emitem um som demasiado autoritário ou gemente demais, formando com seus iguais acordos/acordes mesmo fugidios e não resolvidos, sem outra realização além da liberdade, sempre pronta a libertar-se para realizar-se. A fraternidade, segundo Melville ou Lawrence, e uma questão de almas originais: talvez só comece com a morte do pai ou de Deus, mas não deriva dai, é uma questão inteiramente diferente - 'todas as sutis simpatias da alma inumerável, do mais amargo ódio ao amor mais apaixonado'. [...] Os perigos da 'sociedade sem pais' foram denunciados com frequência, mas o único perigo é o retorno do pai. A esse propósito, não se pode separar o fracasso das duas revoluções, a americana e a soviética, a pragmática e a dialética. A emigração universal não teve mais êxito do que a universal proletarização. A Guerra de Secessão já faz dobrarem os sinos, como o fará a liquidação dos Sovietes. Nascimento de uma Nação, restauração do Estado-nação, e os pais monstruosos retornam galopantes, enquanto os filhos sem pai recomeçam a morrer. Imagens de papel, esse é o destino do Americano bem como do Proletário. Porém, assim como muitos bolchevistas desde 1917 ouviam os poderes diabólicos batendo a porta, os pragmatistas e já Melville viam chegar a mascarada que arrastaria a sociedade dos irmãos. Bern antes de Lawrence, Melville e Thoreau diagnosticavam o mal americano, o novo cimento que restabelece o muro, a autoridade paterna e a imunda caridade. Bartleby se deixa então morrer na prisão. Desde o inicio, Benjamin Franklin, o hipócrita Mercador de para-raios, instala a prisão magnética americana. O navio-cidade reconstitui a lei mais opressiva, e a fraternidade só subsiste nos gajeiros quando eles se mantem imóveis no alto dos mastros (White-Jacket). A grande comunidade dos celibatários não passa de uma companhia de boas-vindas, que certamente não impede o celibatário rico de explorar as pobres operárias lívidas, reconstituindo as duas figuras não reconciliadas do pai monstruoso e das filhas órfãs (O paraíso das celibatárias e o Tártaro das raparigas). Por toda parte em Melville aparece a escroque americana. Qual poder maligna fez do trust uma companhia tão cruel quanto a abominável 'nação universal' fundada pelo Homem dos cães, em The Encantadas? O homem da confiança, onde culmina a crítica melvilliana da caridade e da filantropia, coloca em cena uma série de personagens tortuosos que parecem emanar de um 'Grande Cosmopolita' com roupa de colcha de retalhos e que pedem tão somente... Um pouco de confiança humana para levar adiante uma trapaça múltipla e proliferante. [...] Com efeito, no seio mesmo de seu fracasso, a revolução americana continua relançando seus fragmentos, sempre fazendo fugir algo na linha de horizonte, embarcando para a Lua, tentando perfurar o muro, retomando a experimentação, encontrando uma fraternidade nesse empreendimento, uma irmã nesse devir, uma musica na língua que gagueja, um som puro e acordes desconhecidos em toda a linguagem. O que Kafka diz das 'nações pequenas' é o que Melville já diz da grande nação americana, na medida em que deve ser precisamente o patchwork de todas as nações pequenas." in DELEUZE, Gilles. Crítica e Clínica. São Paulo: Editora 34 Ltda., 1997, p. 98 e ss. Acredita-se que a Teoria do Estado, enquanto disciplina jurídica, carece em demasia de uma análise que considere estas comunidades, por mais extremas e peculiares que possam parecer em suas justificações e leis, como laboratórios da democracia de hoje, iniciada em 1776, e da política que vem, quando enfim as instituições políticas serão pensadas para se alinhar à democracia e não a democracia às instituições políticas. 


\begin{abstract}
This work aims to synthesize knowledge extracted from authors of different traditions of the history of philosophy about the conditions of formation of the Kantian moral landscape with an archaeological method, focused on the historical-philosophical construction of the Kantian notion of duty. The works of Villey and Agamben on the subject were adopted as basic works, as well as fields were delimited, autonomous in relation to whole of Kantian thought, to be approached from the perspective of the initial premise (such as: technics as a paradigm of modernity and the impact of nominalism, protestantism and neoestoicism on Kant). The parts which bore a more "philosophical" character are deeply indebted to Agamben's propositions and sociological observations based on Max Weber's work on intramundane protestant ethics were incorporated to give the reader a more clear view on the subjects. The conclusion, following the studies adopted as conceptual basis, points to the consolidation, in the Kantian work, of a process of alteration of the Weltanschauung of the philosophical intelligentsia in the West, with severe repercussion in the life of the inhabitants of this hemisphere. Considering this conclusion, it is necessary to rethink the notion of duty both in its legal and psychological implications.
\end{abstract}

Keywords: Kantian Theory of Duty; Officium; Causa Instrumentalis; Gestell; Post-Positivist Theory of State and Justice.

\title{
BIBLIOGRAFIA
}

AGAMBEN, Giorgio. Opus Dei: Arqueologia do Ofício. São Paulo: Boitempo Editorial, 2013 (2013a).

The Kingdom and the Glory: For a Theological Genealogy of Economy and Government (Homo Sacer II. 2). Stanford: Stanford University Press, 2011.

Bartleby, ou da contingência. Belo Horizonte: Autêntica Editora, 2015.

State of Exception. Chicago: The University of Chicago Press, 2005. (2013b).

The Highest Poverty: Monastic Rule and Form-of-Life. Stanford: Stanford University Press, 2013

O Uso dos Corpos. São Paulo: Boitempo Editorial, 2017.

Homo Sacer: Sovereign Power and Bare Life. Stanford: Stanford University Press, 1998.

AMBRÓSIO. Exameron Libri Sex. In: MIGNE, Jacques-Paul (org.). Patrologiae cursus completus. Series latina. Parisiis, excudebat Migne, 1844-1864. v. XIV.

De Sacramentis. Des Mystères. Org. Bernard Botte, Paris, Cerf, 1994. [Ed. bras.: Explicações dos símbolos. Sobre os sacramentos. Sobre os mistérios. Sobre a penitência. 2. ed., São Paulo, Paulus, 2005, Patrística 5.] (as referências a esta obra serão feitas tendo como base a edição citada pelo professor Agamben, qual seja, a francesa)

BARROSO. Luís Roberto. "Aqui. lá e em todo lugar”: A Dignidade Humana no Direito Contemporâneo e no Discurso Transnacional. RT 919. Editoria Revista dos Tribunais. Maio de 2012.

BENOIST, Alain de. Types et figures dans l'oeuvre d'Ernst Jünger: Le Soldat du front, le Travailleur, le Rebelle et l'Anarque. Apresentação feita em Roma em Maio de 1997. Acessado através da tradução de Greg Johnson, publicada na revista The Occidental Quarterly, vol. 8, no. 3, edição do outono de 2008.

BÍBLIA DE JERUSALÉM.

CARPEAUX, Otto Maria. História da Literatura Ocidental. São Paulo: Texto Editores Ltda., 2010. 
CÍCERO. Os Deveres. t. 1. São Paulo: Escala, 2008.

COMPARATO, Fábio Konder. Ética - Direito, Moral e Religião no Mundo Moderno. 3ª Edição. São Paulo: Ed. Schwarcz, 2016.

DELEUZE, Gilles. Crítica e Clínica. São Paulo: Editora 34 Ltda., 1997.

DRECOLL, Carsten, Die Liturgien im rômischen Kaiserreich des 3. Und 4. Jh. N. Chr. Untersuchung ûber Zuganf, Inhalt und wirtschaftlice Bedeutung der öffentlichen Zwangdienste in Ägypten und anderen Provinzen. Sttutgart: Steiner, 1997.

FOUCAULT. Michel. O Nascimento da Biopolítica: Curso no Collège de France (1978 - 1979). São Paulo: Ed. Martins Fontes, 2008.

FRANCO DE SÁ, Alexandre. A Política sobre a Linha: Martin Heidegger, Ernst Jünger e a Confrontação sobre a era do Niilismo. Covilhã: LusoSofia Press, 2008.

HEIDEGGER, Martin. Einführung in die Metaphysik Tübingen: Max Niemeyer, 1962.

HEIDEGGER, Martin e JÜNGER, Ernst. Franco Volpi (org). Oltre la Linea. Milão: Adelphi Edizioni, 1989.

HÖFFE. Otfried. Kategorische Rechtsprinzipien. Ein Kontrapunkt der Moderne. Frankfurt: Suhrkamp, 1990.

Categorical Principles of Law: A Counterpoint to Modernity. University Park: The Pennsylvania State University Press, 2002.

JÜNGER, Ernst. O trabalhador: domínio e figura, trad. Alexandre Franco de Sá, Lisboa, Hugin, 2000.

KANT, Emanuel. Crítica da Razão Prática. São Paulo; Brasil Editora S.A., 1959.

KLAUSNER. Guilherme Alfradique. História das Mentalidades Tributárias: Da Antiguidade à Idade Moderna. 2013. 90 f. Universidade Federal Fluminense. Niterói. 2013.

De La Torre Rangel e De La Torre de Lara. La dicta-dura de los instrumentos: ciência y derecho deshumanizados. artigo publicado na Revista Direito e Práxis. Rio de Janeiro. Vol. 07. N. 13. 2016.

DE LIMA LOPES. José Reinaldo. O Direito na História: Lições Introdutórias. São Paulo: Editora Atlas S.A., 2014.

LOBO TORRES, Ricardo. Tratado de Direito Constitucional Financeiro e Tributário, vol. I - Constituição Financeira, Sistema Tributário e estado Fiscal. Rio de Janeiro: Renovar, 2009.

MACINTYRE. Alasdair. After Virtue: A Study in Moral Theory. Notre Dame: University of Notre Dame Press, 3a Edição, 2007.

MOREIRA NETO, Diogo de Figueiredo. Aspectos Jurídicos do Brasil Contemporâneo: O PósPositivismo Chega ao Brasil. Inaugura-se um Constitucionalismo de Transição. Revista Eletrônica sobre a Reforma do Estado, Salvador, no. 6, junho/julho/agosto, 2006. 
MURRAY. Alex e WHYTE. Jessica (Orgs.). The Agamben Dictionary. Edimburgo: Edinburgh University Press, 2011.

NABAIS. José Casalta. O dever fundamental de pagar impostos. Coimbra: Livraria Almedina, 1998.

NIETZSCHE, Friedrich. Opere: Frammenti postumi, 1885-1887 (orgs. Giorgio Colli e Mazzino Montinari). Milão; Adelphi, 1975.

PELBART, Peter Pál. O Avesso do Niilismo: Cartografias do Esgotamento. São Paulo: n-1 Edições, 2013.

RAWLS. John. Uma Teoria da Justiça. São Paulo: Martins Fontes, 2000.

SANDEL. Michael J.. Justice: What's the Right thing to do?. Nova Iorque: Farrar. Straus and Giroux, 2009.

Contra a Perfeição: Ética na era da engenharia genética. Rio de Janeiro: Civilização Brasileira, 2013.

SCHMITT. Carl. Politische Theologie: Vier Kapitel zur Lehre von der Souveränität. Berlim: Duncker \& Humblot, 1996.

Roman Catholicism and Political Form. Westport: Greenwood Press, 1996.

Teologia Política. Belo Horizonte: Editora Del Rey Ltda., 2006.

O nomos da Terra no direito das gentes do jus publicum europaeum. Contraponto Editora Ltda. E

Editora PUC-Rio.: Rio de Janeiro, 2014.

O Conceito do Político. Belo Horizonte: Editora Del Rey Ltda., 2009.

SUÁREZ, Francisco. Opera Omnia. (org, Charles Berton) Paris; Vivès, 1859, v. 13.

TOCQUEVILLE. Alexis de. O Antigo Regime e a Revolução. São Paulo: Editora WMF Martins Fontes, 2009.

\section{TOMÁS DE AQUINO. Summa Theologica.}

VARRÃO. On the Latin Language. Org. Roland G. Kent, Londres/Cambridge (Mass.), Heinemann/Harvard University Press, $1967.2 \mathrm{v}$.

VILLEY. Michel. A Formação do Pensamento Jurídico Moderno. São Paulo: Editora Martins Fontes, 2009.

WEBER. Max. The Protestant Ethic and The Spirit of Capitalism. Nova Iorque: Routledge, 2005.

A ética protestante e o "espírito" do capitalismo. São Paulo: Editora Schwarcz Ltda., 2007.

Economia e Sociedade: Fundamentos da Sociologia Compreensiva, Volume II. Editora UNB, Brasília, 1999.

Trabalho enviado em 06 de março de 2018.

Aceito em 21 de março de 2018. 